Prepared in cooperation with the City of Cambridge, Massachusetts, Water Department

\title{
Surface-Water, Water-Quality, and Meteorological Data for the Cambridge, Massachusetts, Drinking-Water Source Area, Water Years 2007-08.
}

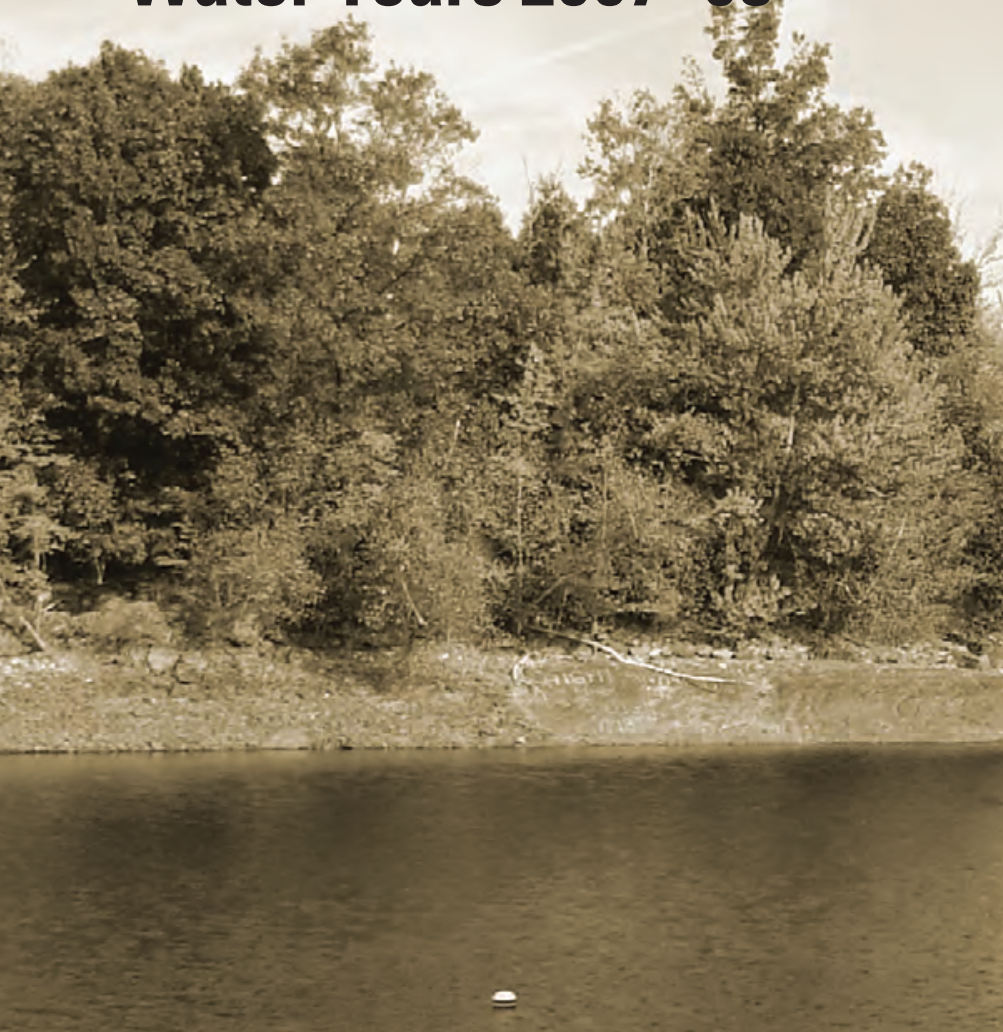

Open-File Report 2011-1077

U.S. Department of the Interior U.S. Geological Survey

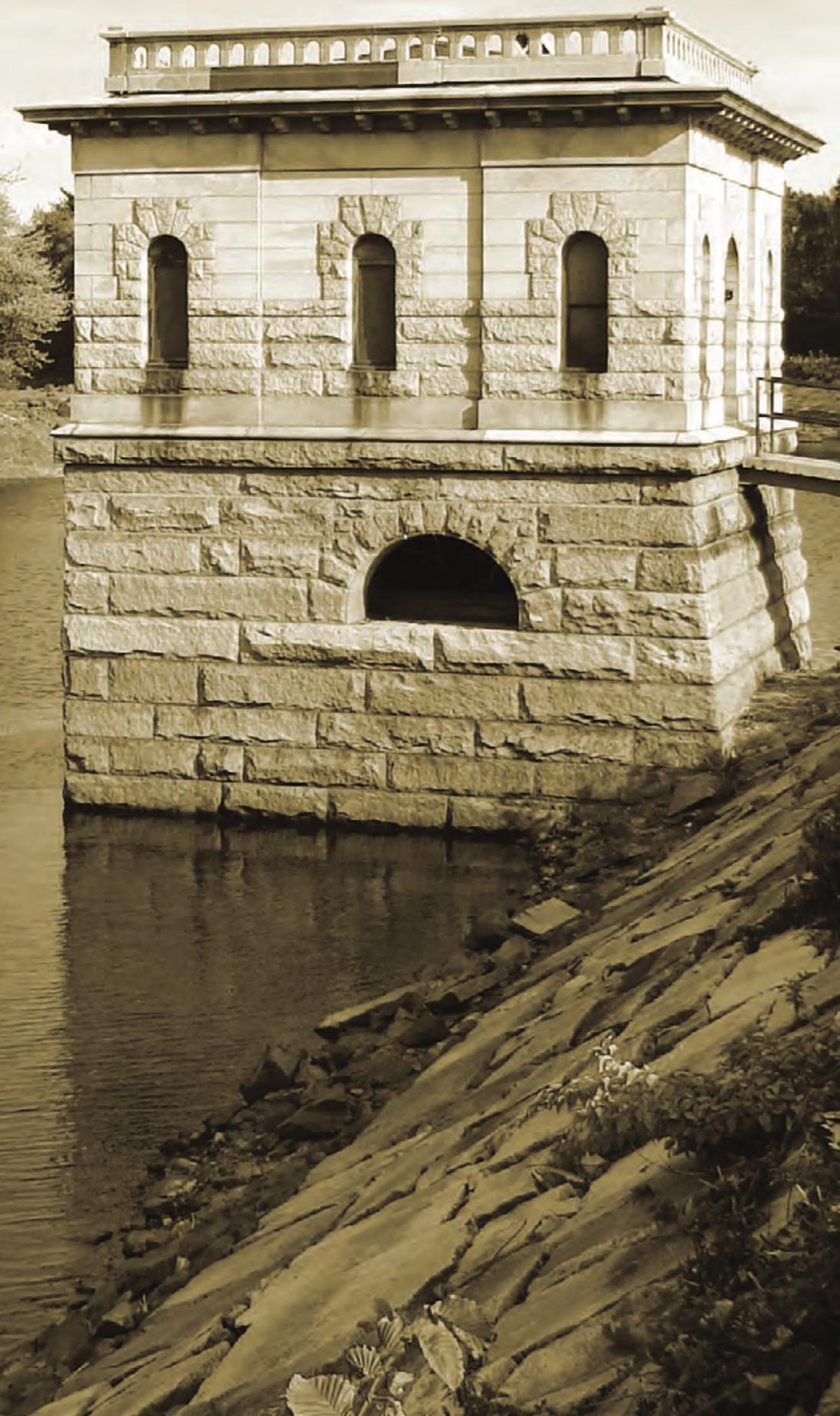


Cover. Photograph of the Cambridge Reservoir at about 40 percent capacity, October 2007. 


\section{Surface-Water, Water-Quality, and Meteorological Data for the Cambridge, Massachusetts, Drinking-Water Source Area, Water Years 2007-08}

By Kirk P. Smith

Prepared in cooperation with the City of Cambridge, Massachusetts, Water Department

Open-File Report 2011-1077 


\title{
U.S. Department of the Interior \\ KEN SALAZAR, Secretary \\ U.S. Geological Survey \\ Marcia K. McNutt, Director
}

\section{U.S. Geological Survey, Reston, Virginia: 2011}

\begin{abstract}
For more information on the USGS - the Federal source for science about the Earth, its natural and living resources, natural hazards, and the environment, visit http://www.usgs.gov or call 1-888-ASK-USGS

For an overview of USGS information products, including maps, imagery, and publications, visit http://www.usgs.gov/ pubprod

To order this and other USGS information products, visit http://store.usgs.gov
\end{abstract}

\begin{abstract}
Any use of trade, product, or firm names is for descriptive purposes only and does not imply endorsement by the U.S Government.

Although this report is in the public domain, permission must be secured from the individual copyright owners to reproduce any copyrighted materials contained within this report.
\end{abstract}

Suggested citation:

Smith, K.P., 2011, Surface-water, water-quality, and meteorological data for the Cambridge, Massachusetts, drinkingwater source area, water years 2007-08: U.S. Geological Survey Open-File Report 2011-1077, 109 p., at http://pubs. usgs.gov/of/2011/1077. 


\section{Contents}

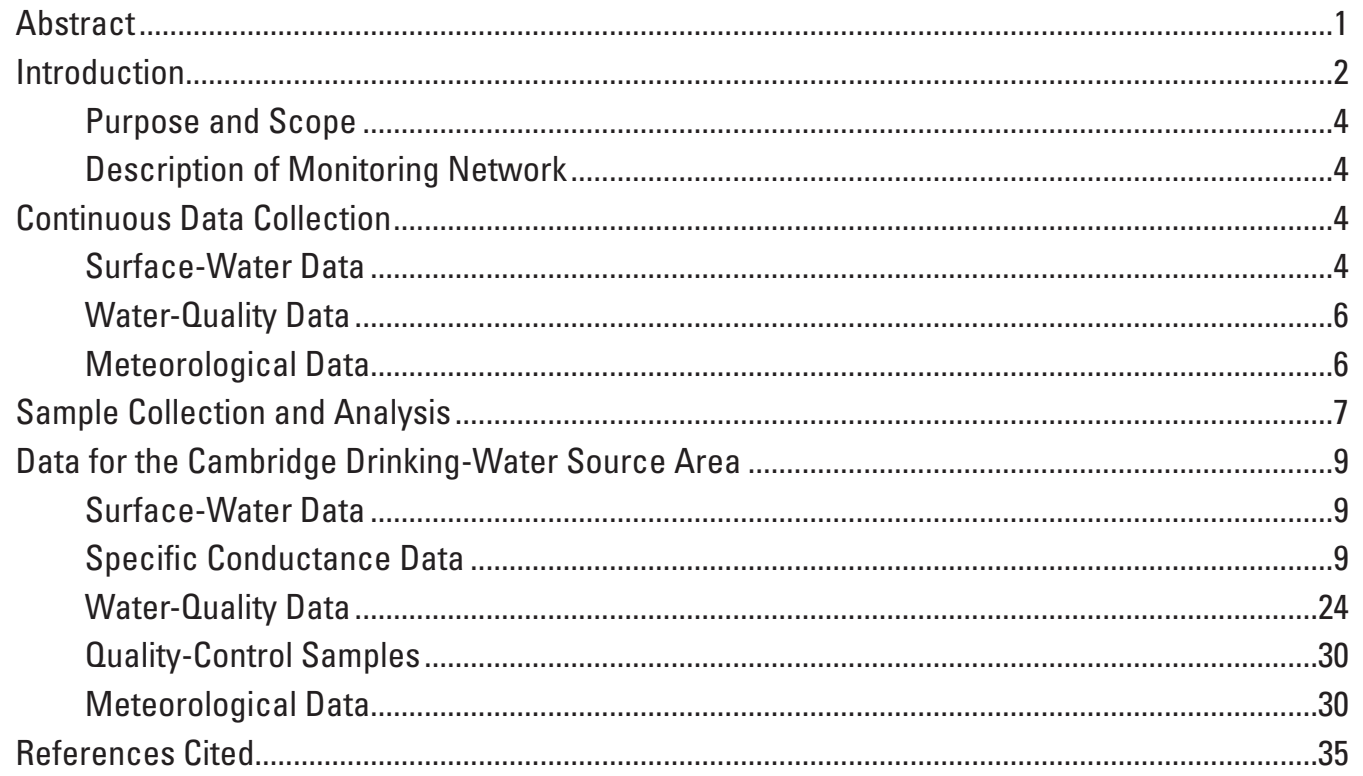

\section{Figures}

1. Map showing monitoring network for the Cambridge, Massachusetts, drinking-water source area for water years 2007-08, eastern Massachusetts.

2. Graph showing discharge from the Cambridge Reservoir as a percentage of water entering the Stony Brook Reservoir, and discharge from the Stony Brook Reservoir to the Charles River as a percentage of total inflow to the Stony Brook Reservoir for water years 2007-08.

3. Graph showing monthly mean reservoir storage as a percentage of capacity for water years 2007-08 for the Cambridge Reservoir, Stony Brook Reservoir, and the Fresh Pond Reservoir.

4. Graph showing comparison of specific conductance for water years 2007-08 to prior specific conductance data for U.S. Geological Survey station 01104415, Cambridge Reservoir, unnamed tributary number 2, near Lexington, Massachusetts...17

5. Graph showing comparison of specific conductance for water years 2007-08 for U.S. Geological Survey station 01104430, Hobbs Brook below Cambridge Reservoir near Kendal Green, Massachusetts.

6. Graph showing comparison of specific conductance for water year 2007 for U.S.Geological Survey station 01104433, Hobbs Brook unnamed tributary number 1, near Kendal Green, Massachusetts.

7. Graph showing comparison of specific conductance for water years 2007-08 for U.S. Geological Survey station 01104455, Stony Brook, unnamed tributary number 1, near Waltham, Massachusetts....

8. Graph showing comparison of specific conductance for water years 2007-08 for U.S. Geological Survey station 01104460, Stony Brook at Route 20 at Waltham, Massachusetts 
9. Graph showing comparison of specific conductance for water years 2007-08 for U.S. Geological Survey station 01104475, Stony Brook Reservoir, unnamed tributary number 1, near Weston, Massachusetts.

10. Graph showing comparison of specific conductance for water years 2007-08 for U.S. Geological Survey station 422302071083801, Fresh Pond in Gate House at Cambridge, Massachusetts

11. Graph showing monthly mean reservoir storage as a percentage of capacity and specific conductance for water years 2007-08 for U.S. Geological Survey station 01104430, Hobbs Brook below Cambridge Reservoir, near Kendal Green, Massachusetts

12. Graph showing monthly precipitation for water years 2007-08 for U.S. Geological Survey station 01104430, Hobbs Brook below Cambridge Reservoir, near Kendal Green, Massachusetts.

\section{Tables}

1. Names, locations, drainage areas, and periods of record for U.S. Geological Survey monitoring stations in the drinking-water source area for Cambridge,

Massachusetts, water years 2007-08

2. Hydrologic, water-quality, and meteorological parameters measured at each continuous-monitoring station during water years 2007-08 in the drinking-water source area for Cambridge, Massachusetts

3. Monthly mean discharge for U.S. Geological Survey stations in the drinking-water source area for Cambridge, Massachusetts, for water years 2007-08.

4. Monthly and annual totals for precipitation for U.S. Geological Survey stations in the drinking-water source area for Cambridge, Massachusetts, for water years 2007-08

5. Monthly and annual statistics for daily mean specific conductance for U.S. Geological Survey stations in the drinking-water source area for Cambridge, Massachusetts, for water years 2007-08.

6. Physical properties of and concentrations of dissolved calcium, sodium, chloride, sulfate, total nutrients, polar pesticides and metabolites, petroleum hydrocarbons, and suspended sediment in base-flow and stormflow water samples collected in 11 subbasins and for water samples collected from the Fresh Pond intake structure in the Cambridge, Massachusetts, drinking-water source area in water years 2007-08

7. Characteristics of selected pesticides detected in samples of base-flow and stormflow collected in the Hobbs Brook and Stony Brook Reservoir Basins, Massachusetts, water years 2007-08.

8. Frequency of detection and maximum concentration of selected pesticides and caffeine in six samples of base-flow and six samples of stormflow collected in the Hobbs Brook and Stony Brook Basins and in four samples of raw-water collected from the intake of the water-treatment facility at Fresh Pond, Massachusetts, water years 2007-08.

9. Physical properties and concentrations of dissolved calcium, sodium, chloride, sulfate, total nutrients, polar pesticides and metabolites, in quality-control samples collected in the Cambridge, Massachusetts, drinking-water source area during water years 2007-08

10. Recovery statistics for organic compounds in laboratory-spiked preparation samples and recoveries for field-spiked samples for the Cambridge, Massachusetts, drinking water source area during water years 2007-08. 


\section{Conversion Factors, Datum, and Abbreviations}

\begin{tabular}{lcl}
\hline Multiply & By & To obtain \\
\hline inch (in.) & Length & \\
inch (in.) & 2.54 & centimeter $(\mathrm{cm})$ \\
inch (in.) & 25.4 & millimeter $(\mathrm{mm})$ \\
foot (ft) & 254 & micrometer $(\mu \mathrm{m})$ \\
mile (mi) & 0.3048 & meter $(\mathrm{m})$ \\
\hline & 1.609 & kilometer $(\mathrm{km})$ \\
\hline square inch $\left(\mathrm{in}^{2}\right)$ & Area & \\
square mile $\left(\mathrm{mi}^{2}\right)$ & 6.452 & square centimeter $\left(\mathrm{cm}^{2}\right)$ \\
& 2.590 & square kilometer $\left(\mathrm{km}^{2}\right)$ \\
\hline gallon (gal) & Volume & \\
\hline & 3.785 & liter $(\mathrm{L})$ \\
\hline $\begin{array}{l}\text { million gallons per day } \\
\quad \text { Mgal/d) }\end{array}$ & Flow rate & \\
million gallons per day per & 0.04381 & cubic meter per second $\left(\mathrm{m}^{3} / \mathrm{s}\right)$ \\
square mile $\left[(\mathrm{Mgal} / \mathrm{d}) / \mathrm{mi}^{2}\right]$ & 1,461 & cubic meter per day per square kilometer \\
\hline
\end{tabular}

Horizontal coordinate information is referenced to the North American Datum of 1983 (NAD 83).

Altitude, as used in this report, refers to distance above the vertical datum.

Specific conductance is given in microsiemens per centimeter at 25 degrees Celsius $\left(\mu \mathrm{S} / \mathrm{cm}\right.$ at $\left.25^{\circ} \mathrm{C}\right)$.

Water- and sediment-quality constituents are expressed in milligrams per liter (mg/L), micrograms per liter $(\mu \mathrm{g} / \mathrm{L})$. Milligrams per liter is a unit expressing the concentration of chemical constituents in solution as weight (milligrams) of solute per unit volume (liter) of water. One thousand milligrams per liter is equivalent to one gram per liter. One thousand micrograms per liter is equivalent to one milligram per liter. For concentrations less than $7,000 \mathrm{mg} / \mathrm{L}$, the numerical value is the same as for concentrations in parts per million (ppm).

\section{Acronyms Used in Report}

$\begin{array}{ll}\text { ASTM } & \text { American Society for Testing and Materials } \\ \text { COV } & \text { coefficient of variation } \\ \text { CWD } & \text { City of Cambridge, Massachusetts, Water Department } \\ \text { HPLC } & \text { high-performance liquid chromatography } \\ \text { ISO } & \text { International Organization for Standardization } \\ \text { NIST } & \text { National Institute of Standards and Technology } \\ \text { NWQL } & \text { National Water Quality Laboratory } \\ \text { NTRU } & \text { nephelometric turbidity ratio units } \\ \text { RPD } & \text { relative percent difference } \\ \text { USEPA } & \text { U.S. Environmental Protection Agency } \\ \text { USGS } & \text { U.S. Geological SurveyThis page has been left blank intentionally. }\end{array}$


This page has been left blank intentionally. 


\title{
Surface-Water, Water-Quality, and Meteorological Data for the Cambridge, Massachusetts, Drinking-Water Source Area, Water Year 2007-08
}

\author{
By Kirk P. Smith
}

\section{Abstract}

Records of water quantity, water quality, and meteorological parameters were continuously collected from three reservoirs, two primary streams, and five subbasin tributaries in the Cambridge, Massachusetts, drinking-water source area during water years 2007-08 (October 2006 through September 2008). Water samples were collected during base-flow conditions and storms in the Cambridge Reservoir and Stony Brook Reservoir drainage areas and analyzed for dissolved calcium, sodium, chloride, and sulfate; total nitrogen and phosphorus; and polar pesticides and metabolites. Composite samples of stormwater also were analyzed for concentrations of total petroleum hydrocarbons and suspended sediment in one subbasin in the Stony Brook Reservoir drainage basin. These data were collected to assist watershed administrators in managing the drinking-water source area and to identify potential sources of contaminants and trends in contaminant loading to the water supply.

Monthly reservoir contents for the Cambridge Reservoir ranged from about 30 to 95 percent of capacity during water years 2007-08. Monthly reservoir contents for the Stony Brook Reservoir ranged from about 47 to 91 percent of capacity during water years 2007-08, while the monthly reservoir storage values for Fresh Pond Reservoir were maintained at greater than 92 percent of capacity. If the average water demand by the city of Cambridge is assumed to be 15 million gallons per day, the volume of water released from the Stony Brook Reservoir to the Charles River during water years 2007-08 represents an annual surplus of about 107 and 94 percent, respectively. The annual precipitation total of about 47 in (inches) recorded at the Cambridge reservoir during water year 2007 was about 5 to 21 percent lower than recorded totals for the previous four water years, whereas the annual precipitation total of about 62 in. during water year 2008 was about 5 to 32 percent higher than recorded totals for water years 2002-07.

In general, most monthly mean specific-conductance values for water year 2007 for U.S. Geological Survey (USGS) stations on the two primary streams and four subbasin tributaries in the Cambridge, Massachusetts, drinkingwater source area were below the previous median monthly values and often were below the previous minimum monthly values for available data since water year 1997. The annual mean specific-conductance value for Fresh Pond Reservoir during water year 2007 was $483 \mu \mathrm{S} / \mathrm{cm}$ (microsiemens per centimeter), which was lower than the prior three water years. The monthly mean specific-conductance values for streamflow for Hobbs Brook below the Cambridge Reservoir for December through July 2008 were greater than the 75th percentile for historical data since water year 1997. These relatively high values were caused by the inflow of high specific conductance water from the tributaries when the reservoir water level was low at the onset of winter. Increased rainfall in the watershed beginning in February 2008 caused monthly mean specific-conductance values for Hobbs Brook to decrease to about $700 \mu \mathrm{S} / \mathrm{cm}$ by the end of the water year. Monthly mean specific-conductance values for many of the other USGS stations were higher than historical values for several months during the winter of water year 2008. The large amount of rainfall in the watershed also caused the monthly mean specific conductance at these stations to decline to near-median values or to values within the interquartile range for available historical data. The annual mean specific conductance for Fresh Pond Reservoir during water year 2008 was $497 \mu \mathrm{S} / \mathrm{cm}$, slightly greater than the corresponding value for the prior year.

Water samples were collected in nearly all of the subbasins in the Cambridge drinking-water source area and from Fresh Pond during the study period. Discrete water samples were collected during base-flow conditions with an antecedent dry period of at least 3 days. Composite samples, consisting of as many as 100 subsamples, were collected by automatic samplers during storms. Concentrations of most dissolved constituents were generally lower in samples of stormwater than in samples collected during base-flow conditions; however, the difference between the average concentration of total phosphorus in samples of stormwater and for samples collected during base-flow conditions in the tributaries ranged from 0.10 to $0.23 \mathrm{mg} / \mathrm{L}$ (milligrams per liter). Concentrations of dissolved calcium, sodium, chloride, 
and sulfate in water samples collected in the drinking-water source area (excluding Fresh Pond Reservoir) ranged from 2.99 to $75.8 \mathrm{mg} / \mathrm{L}, 7.47$ to $534 \mathrm{mg} / \mathrm{L}, 11.4$ to $1,050 \mathrm{mg} / \mathrm{L}$, and 2.85 to $47.2 \mathrm{mg} / \mathrm{L}$, respectively. The concentration of total phosphorus and total nitrogen in water samples for all subbasins ranged from 0.006 to $0.53 \mathrm{mg} / \mathrm{L}$, and 0.42 to $3.14 \mathrm{mg} / \mathrm{L}$, respectively.

In 3 of 81 water samples, measurements of $\mathrm{pH}$ were less than the U.S. Environmental Protection Agency (USEPA) secondary drinking-water standard of $6.5 \mathrm{pH}$ units. Concentrations of dissolved chloride in all water samples collected during base-flow conditions from USGS stations 01104410, 01104415, 01104420, 01104433, and 01104455 were near or exceeded the USEPA secondary drinking-water standard of $250 \mathrm{mg} / \mathrm{L}$. All samples collected during baseflow conditions at USGS stations 01104415 and 01104433 , and five of six samples collected at USGS station 01104455 exceeded the secondary drinking-water standard for chloride. The concentration of chloride in composite samples of stormwater also exceeded the standard at USGS stations 01104415, 01104433 , and 01104455 for a few winter storms. Concentrations of dissolved sulfate in all water samples were below the USEPA secondary drinking-water standard of $250 \mathrm{mg} / \mathrm{L}$. Concentrations of dissolved sodium for all samples collected in the drinking-water source area exceeded the Massachusetts drinking water guideline $(20 \mathrm{mg} / \mathrm{L})$ with the exception of three composites samples of stormwater collected at USGS stations 01104455 and 01104475.

Eighteen pesticides and caffeine were detected in water samples collected in the primary streams and tributaries to the Cambridge Reservoir and Stony Brook Reservoir, and in raw water collected from the Cambridge water-treatment facility intake from the Fresh Pond Reservoir during water years 2007-08. Caffeine was detected in 54 percent of 80 water samples at concentrations ranging from 0.004 to 0.557 micrograms per liter. Caffeine was detected in water samples collected at all USGS sampling stations except for 01104390, 01104410, 01104453. Imidacloprid, siduron, and norflurazon were the most frequently detected pesticides, with measureable concentrations in 29 to 32 percent of all water samples collected in the drinking-water source area. Caffeine, 2,4-D, and benomyl were more frequently detected in water samples collected during storms than in water samples collected during base-flow conditions. Imidacloprid, siduron, and 2,4-D were frequently detected in water samples from the tributaries to the Cambridge and Stony Brook Reservoirs. Trace amounts of caffeine, carbaryl, dinoseb, norflurazon, and siduron were also detected in water from the Fresh Pond Reservoir.

\section{Introduction}

Hydrologic and water-quality monitoring is important for the effective management and protection of drinking-water supplies. Both the quantity and the quality of water are monitored because these factors determine the physical, chemical, and biological state of the water supply. Without accurate information on the past and current condition of the water supply, effective preservation and remediation programs cannot be implemented or evaluated.

The U.S. Geological Survey (USGS) works closely with municipal water suppliers throughout the Nation to address specific water problems by conducting hydrologic- and water-quality-monitoring programs and detailed investigations (Patterson, 1997). One such program, conducted during 1997-98 by the USGS in cooperation with the city of Cambridge, Massachusetts, Water Department (CWD), was designed to identify sources of contaminants in the drinkingwater source area for the city (Waldron and Bent, 2001). Subsequently the USGS, in cooperation with the CWD, designed and implemented a water-monitoring network in the drinking-water source area. Data from this network have been published periodically in various USGS reports (Smith, 2005, 2007 and 2008; Socolow and others, 1999, 2000, 2001, 2002, 2003, and 2004; U.S. Geological Survey, 2009).

The CWD supplies approximately $15 \mathrm{Mgal} / \mathrm{d}$ (million gallons per day; Waldron and Bent, 2001) to more than 100,000 customers. Most of this water is obtained from three primary storage reservoirs - Cambridge Reservoir (also known as the Hobbs Brook Reservoir), Stony Brook Reservoir, and Fresh Pond Reservoir - in parts of Lexington, Lincoln, Waltham, Weston, and Cambridge (fig. 1). The watershed for the Cambridge Reservoir includes Hobbs Brook and three unnamed tributaries that discharge directly into the reservoir. Water is discharged from the southern end of the Cambridge Reservoir into Hobbs Brook, which receives additional water from an unnamed tributary about $0.5 \mathrm{mi}$ (miles) below the reservoir. Hobbs Brook joins with Stony Brook about $1.6 \mathrm{mi}$ downstream from the reservoir and flows south to the Stony Brook Reservoir. The area above this confluence is herein referred to as the Hobbs Brook Basin. Two unnamed tributaries flow into Stony Brook about a 0.25 mi north of the Stony Brook Reservoir. In addition to Stony Brook, an unnamed tributary flows directly into the Stony Brook Reservoir on the southwestern side of the reservoir. Additional water enters both reservoirs from other minor tributaries and roadway and parking-lot storm drains. Water from Stony Brook Reservoir is piped through an aqueduct by the CWD directly to Fresh Pond Reservoir, where it is stored prior to treatment. Overflow and controlled discharges from the Stony Brook Reservoir flow into the Charles River in Waltham.

The drainage basin contributing water to these reservoirs has undergone rapid development since the 1990s and encompasses major transportation corridors (Interstate 95, Routes 2, 2A, 20, and 117), as well as large areas of industrial, commercial, and high-density residential land use. Because the city of Cambridge owns less than 5 percent of the land in the basin contributing to its water supply, the CWD relies heavily on monitoring to provide information for optimizing the management of its reservoirs for water quality and 

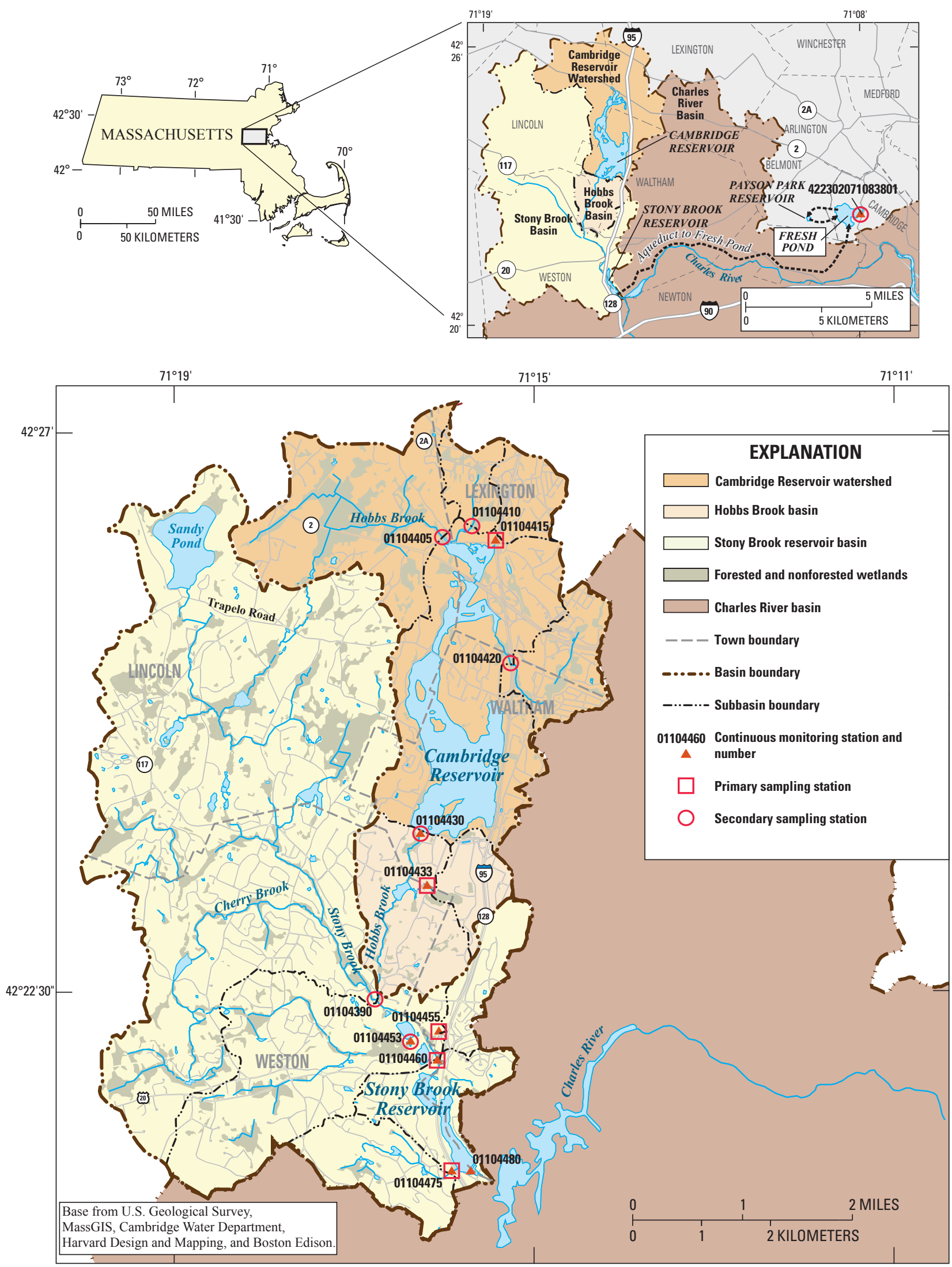

Figure 1. Monitoring network for the Cambridge, Massachusetts, drinking-water source area for water years 2007-08, eastern Massachusetts. 
quantity. The USGS monitoring network provides nearreal-time information that assists the CWD in responding rapidly to water-quality changes caused by accidental or intentional contamination. This information also benefits the CWD, other municipalities, and State agencies involved with water-resource development and management in the Charles River Basin by enhancing their understanding of the relation between local drinking-water-management practices and regional issues of water supply and hydrologicsystem response.

\section{Purpose and Scope}

This report presents records of water quantity, water quality, and meteorological parameters collected in the Cambridge, Massachusetts, drinking-water source area during water years 2007-08 (October 2006 through September 2008). It describes the monitoring network and the data-collection methods for all types of data. It also describes the chemical characteristics of water samples collected during base-flow conditions and during storms from streams and tributaries to Hobbs Brook and Stony Brook in the Stony Brook Reservoir Basin, and of water samples collected from the raw-water intake at the Cambridge water-treatment facility.

\section{Description of Monitoring Network}

Stations installed and operated by the USGS in the drinking-water source area continuously monitored various hydrologic, water-quality, and meteorological parameters, including stream stage, stream-water temperature, stream specific conductance, reservoir altitude, air temperature, and precipitation. Stations were selected for continuous monitoring on the basis of the necessity for water-supply regulation by the CWD and of information gained in a previous USGS investigation (Waldron and Bent, 2001) that identified specific areas as potentially important sources of contaminants. Attributes of the monitoring stations are listed in table 1; locations of stations selected for continuous monitoring are shown in figure 1 .

Stream-stage measurements were recorded at monitoring stations at the outlet of the Cambridge Reservoir, on an unnamed tributary to Stony Brook, on Stony Brook, and at the outlet of Stony Brook Reservoir (USGS stations 01104430, 01104453, 01104460, and 01104480, respectively). The USGS station 01104453 was decommissioned at the end of water year 2007 as a result of construction activity in the monitoring area. Water temperature and specific conductance measurements were recorded at the outlet of the Cambridge Reservoir and at Stony Brook (USGS stations 01104430 and 01104460 ). A water temperature and specific conductance monitor was installed at the outlet of the Stony Brook Reservoir (01104480) late in the summer of 2008. Physical parameters monitored at these sites are listed in table 2. These data were recorded at a frequency of 10 minutes and - with the exception of data from USGS station 01104453 , which was not equipped with telemetrywere uploaded to a USGS database hourly by phone modem. In addition to measurements made on these streams, streamstage measurements and water-quality measurements were recorded at monitoring stations on four of the small tributaries (USGS stations 01104415, 01104433, 01104455, and 01104475). The USGS station 01104433 was decommissioned at the end of water year 2007. Because the drainage areas of these sites are small, each less than $1 \mathrm{mi}^{2}$ (square mile), and contain many roadways, parking lots, and other impervious surfaces (Waldron and Bent, 2001), the hydrologic responses, and often the water-quality responses, change rapidly. To document these responses effectively, the monitoring stations recorded stream-stage and water-quality measurements at variable frequencies, as often as every minute. These data were uploaded to a USGS database hourly by digital cellular modem.

Measurements of reservoir altitude, precipitation, and air temperature were recorded at the Cambridge, Stony Brook, and Fresh Pond Reservoirs (USGS stations 01104430 , 01104480, and 422302071083801). Measurements of reservoir water quality also were recorded at the Fresh Pond Reservoir. Physical parameters monitored at these sites are listed in table 2. These data were recorded at a frequency of 10 to 15 minutes and were uploaded to a USGS database on an hourly basis by phone modem.

\section{Continuous Data Collection}

The monitoring network provides near-real-time information used to manage the quantity and quality of water in the CWD drinking-water source area. Available data from each station are available to watershed managers through the USGS Massachusetts-Rhode Island Water Science Center home page (http://ma.water.usgs.gov).

\section{Surface-Water Data}

Basic data collected at the monitoring stations include records of stream stage and measurements of discharge of streams, and water altitude and contents of reservoirs. In addition, observations of factors affecting the stage-discharge relation or the altitude-contents relation, weather records, and other information are used to supplement the basic data in determining the daily flow or water in storage. Measurements of discharge are made with a current meter or acoustic Doppler current profiler by standard USGS methods (Buchanan and Somers, 1968, 1969; Carter and Davidian, 1968; Kennedy, 1983 and 1984; Oberg and others, 2005; Rantz and others, 1982). The methods are consistent with the American Society for Testing and Materials (ASTM) standards and generally follow the standards of the International Organization for Standards (ISO). 


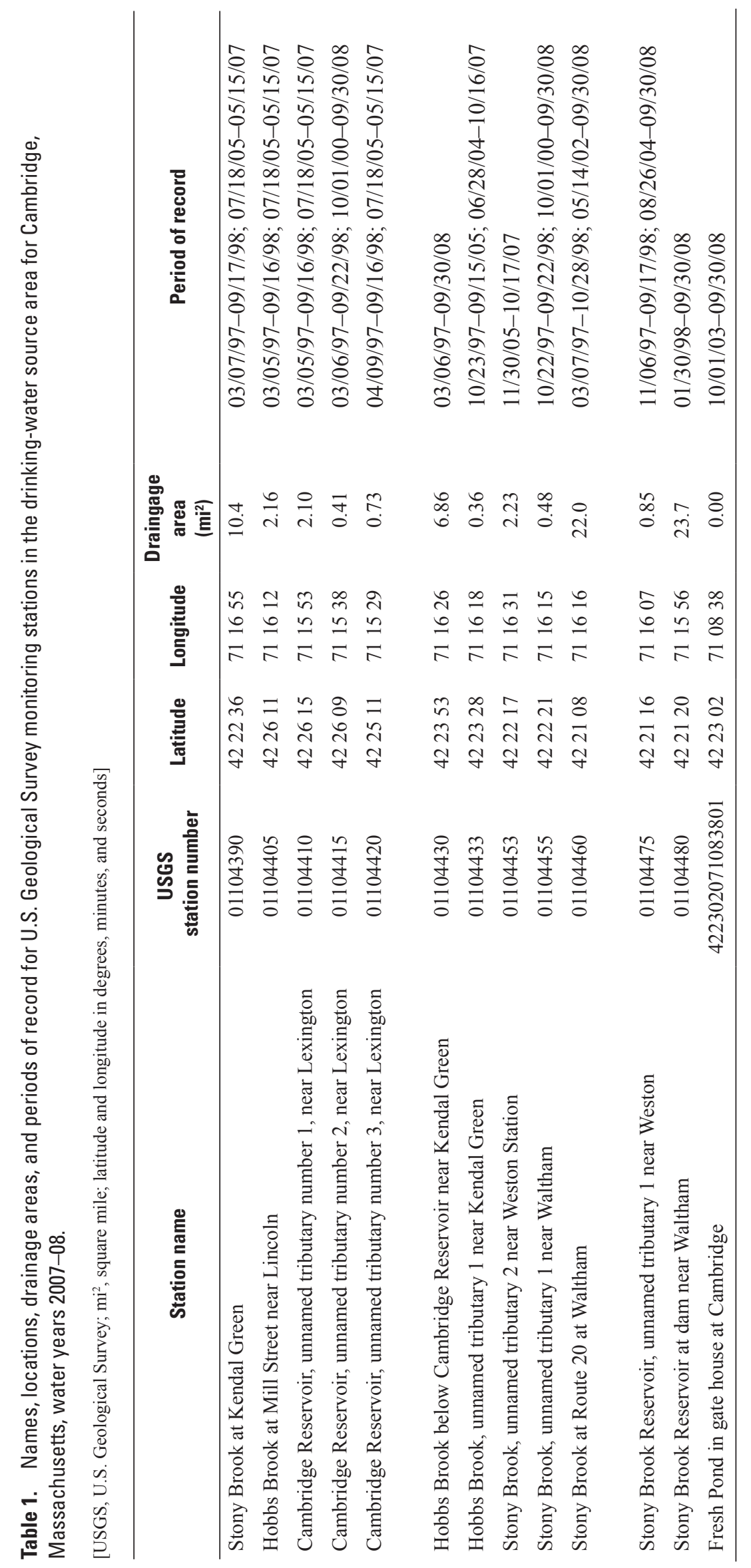


Table 2. Hydrologic, water-quality, and meteorological parameters measured at each continuous-monitoring station during water years 2007-08 in the drinking-water source area for Cambridge, Massachusetts.

$[\mathrm{X}$, indicates parameter is measured $]$

\begin{tabular}{lccccccccc}
\hline \multirow{2}{*}{ Parameter } & \multicolumn{8}{c}{ U.S. Geological Survey station number } \\
\cline { 2 - 10 } & $\mathbf{0 1 1 0 4 4 1 5}$ & $\mathbf{0 1 1 0 4 4 3 0}$ & $\mathbf{0 1 1 0 4 4 3 3}$ & $\mathbf{0 1 1 0 4 4 5 3}$ & $\mathbf{0 1 1 0 4 4 5 5}$ & $\mathbf{0 1 1 0 4 4 6 0}$ & $\mathbf{0 1 1 0 4 4 7 5}$ & $\mathbf{0 1 1 0 4 4 8 0}$ & $\mathbf{4 2 2 3 0 2 0 7 1 0 8 3 8 0 1}$ \\
\hline Stream water level & $\mathrm{X}$ & $\mathrm{X}$ & $\mathrm{X}$ & $\mathrm{X}$ & $\mathrm{X}$ & $\mathrm{X}$ & $\mathrm{X}$ & $\mathrm{X}$ & \\
Reservoir water level & & $\mathrm{X}$ & & & & & & $\mathrm{X}$ & $\mathrm{X}$ \\
Precipitation & & $\mathrm{X}$ & & & & & & $\mathrm{X}$ & $\mathrm{X}$ \\
Air temperature & & $\mathrm{X}$ & & & & & & $\mathrm{X}$ & $\mathrm{X}$ \\
Water temperature & $\mathrm{X}$ & $\mathrm{X}$ & $\mathrm{X}$ & & $\mathrm{X}$ & $\mathrm{X}$ & $\mathrm{X}$ & $\mathrm{X}$ & $\mathrm{X}$ \\
Specific conductance & $\mathrm{X}$ & $\mathrm{X}$ & $\mathrm{X}$ & & $\mathrm{X}$ & $\mathrm{X}$ & $\mathrm{X}$ & $\mathrm{X}$ & $\mathrm{X}$ \\
\hline
\end{tabular}

To determine streamflow at each USGS monitoring station in the CWD drinking-water source area, dischargerating tables for any stage are prepared from stage-discharge curves (Rantz and others, 1982). The daily mean discharge is computed from these stage and rating tables, and then the monthly and yearly mean discharges are computed from these daily values (U.S. Geological Survey, 2009). If the stage-discharge relation for a station is changed temporarily by aquatic growth, scour, or debris in the control section, the daily mean discharge is computed by the shifting-control method (Rantz and others, 1982).

For the USGS monitoring stations at reservoirs in the CWD drinking-water source area, altitude-capacity tables giving the volume for any reservoir water altitude are prepared from water altitude-volume relation curves defined by surveys conducted by the USGS in 2008. From the altitude-capacity tables, the daily, monthly, or yearly changes in volume are computed (U.S. Geological Survey, 2009).

\section{Water-Quality Data}

Continuous water-temperature and specific-conductance data were collected from water-quality monitors in each stream, tributary, and from the Fresh Pond reservoir. The accuracy of the water-quality records depends primarily on the rate of sensor drift, sensor fouling, and debris collection. Typically, sensors became fouled by aquatic growth more rapidly in the warmer months. In most cases, corrections for fouling and drift can be applied to the data to improve their accuracy (Wagner and others, 2006a). For parameters other than water temperature, such corrections were made on the basis of the performance of the sensor before and after sensor maintenance, and by noting the response of the clean sensor after placing it in several standardized solutions. The accuracy of water-temperature data is determined by comparing measurements made by the monitoring system and by an independent probe calibrated against a National Institute of Standards and Technology (NIST) traceable thermometer.
The daily maximum, minimum, and mean values are computed (U.S. Geological Survey, 2009) from instantaneous measurements of water temperature and specific conductance; monthly statistics are then computed from daily values.

Water samples were collected in nearly all of the subbasins in the Cambridge drinking-water source area and from the raw-water intake to the treatment plant at Fresh Pond Reservoir during water year 2007; a water sample also was collected at USGS station 01104475 and the raw-water intake to the treatment plant at Fresh Pond Reservoir during water year 2008. Six water samples were collected manually during base-flow conditions and six composite samples of stormwater were collected with automatic samplers at most of the primary sampling sites (USGS stations 01104415,01104433 , 01104455,01104460 , and 01104475). Four samples of water from Fresh Pond Reservoir were collected from the rawwater intake at the Cambridge water treatment plant. Water samples also were collected from secondary sampling sites (USGS stations 01104390, 01104405, 01104410, 01104420, 01104430, and 01104453) during two synchronous sampling rounds on December 11-12, 2006, and on May 15, 2007, when samples of base-flow water were collected at primary sampling stations (fig. 1) during the same day. Various qualityassurance samples were also collected to determine bias and precision associated with the sample data. All samples were analyzed for physical properties and concentrations of dissolved calcium, sodium, chloride, sulfate, total nutrients, and polar pesticides and metabolites.

\section{Meteorological Data}

Precipitation data were collected with heated tippingbucket precipitation gages that measure the volume of rain or melted snow in increments of 0.01 in. (inch). The precipitation gages at the Cambridge Reservoir and Stony Brook Reservoir include wind screens that reduce bias generated by precipitation missing the instrument. Precipitation data are summed for each day and then for each month 
(U.S. Geological Survey, 2009). In general, the accuracy of precipitation data is assured by proper maintenance and calibration of the device. Precipitation measurements are affected by strong winds and are subject to errors, especially when the precipitation is in the form of snow. These errors generally result in underestimation of the total rainfall at a station.

Air-temperature data were collected with thermistors housed in gill radiation shields. The probes are installed approximately $8 \mathrm{ft}$ (feet) above ground surface. The maximum, minimum, and mean temperature values are computed for each day (U.S. Geological Survey, 2009). Monthly statistics are then computed from daily values. The accuracy of airtemperature data is determined by comparing measurements made by the monitoring system and by an independent probe calibrated against a NIST traceable thermometer.

\section{Sample Collection and Analysis}

Water samples were collected during base-flow conditions and during rain and mixed precipitation storms in selected streams in the drinking-water source area during water years 2007-08. Samples of water from Fresh Pond Reservoir also were collected from the raw-water intake at the Cambridge water treatment plant. All water samples were analyzed for physical parameters; dissolved calcium, sodium, chloride, and sulfate; total nitrogen and total phosphorus; dissolved caffeine; and 60 pesticides and metabolites. Concentrations of total petroleum hydrocarbons and suspended sediment (including the percentage of particles less than $0.063 \mathrm{~mm}$ (millimeters) in diameter) also were measured in composite samples of stormwater collected at USGS station 01104455 to provide baseline information prior to proposed redevelopment activities within the tributary subbasin.

Water samples were collected during base-flow conditions and during storms at five continuously monitored stations in the Hobbs Brook Basin and Stony Brook Reservoir Basin. Four stations are located on small tributaries (USGS monitoring stations $01104415,01104433,01104455$, and 01104475) and one station is located on Stony Brook (USGS monitoring station 01104460; fig. 1 and table 1). Water samples were collected during base-flow conditions on December 11-12, 2006, and May 15, 2007, at several previously monitored USGS stations (Waldron and Bent, 2001) in the Hobbs Brook Basin and Stony Brook Reservoir Basin. These secondary sampling stations (fig. 1 and table 1) include Stony Brook above the confluence of Hobbs Brook, Hobbs Brook above the Cambridge Reservoir, two unnamed tributaries to the Cambridge Reservoir, Hobbs Brook below the Cambridge Reservoir, and an unnamed tributary to Stony Brook (USGS stations 01104390, 01104405, 01104410, 01104420, 01104430, and 01104453, respectively). Samples of stream water were collected manually (Wilde and others, 1999) under base-flow conditions with an antecedent dry period of at least 3 days. During storms, water samples for chemical analysis were collected with an automatic sampler controlled by a datalogger. The first sample was collected when flow exceeded a preset discharge threshold, and subsequent samples were collected at flow-proportional intervals. The automatic collection of samples continued for a specified amount of time after the final peak rate of flow. The time value for each site was calculated on the basis of the size of each drainage area, except for USGS station 01104460 , using the equation

$$
T=A^{0.2},
$$

where $T$ is the time value in days, $A$ is the area of the drainage basin in square miles, and 0.2 is a constant (Bedient and Huber, 2002). For USGS station 01104460, the area upstream of the Cambridge Reservoir is subtracted from the total drainage area because the flow from the upper basin is regulated and not affected by stormwater runoff. Each automatic sampler was configured to hold one 20L (liter) glass bottle and fitted with a pre-cleaned 1/2-in. inner diameter Teflon intake and discharge tube, and a short piece of silicon pump-head tube.

A multi-step process was used to clean all wetted parts associated with the automatic sampler and the processing equipment before each sample collection. The initial cleaning consisted of washing the interior and exterior with a phosphate-free laboratory-grade soap and tap water, scrubbing surfaces with a plastic brush, and rinsing with tap water. Circulating the solution through the tubing cleaned the interior of the sampler tubing. Lint-free wipes were forced hydraulically through the tubing to remove internal deposits or films that were difficult to remove by circulating solution alone. After the components dried, they were placed in a large stainless-steel pan in a fume hood and immersed in Optima-grade methanol. A Teflon diaphragm pump was used to circulate the methanol through the sampler tubing. The components were allowed to soak, with occasional agitation, for a minimum period of about 4 hours. After appropriately dispensing the waste solution, all components except the tubing were rinsed with methanol and air-dried in a fume hood over night. Because the rate of cleaning-solution volatilization is limited within the sampler tubing, the tubing was purged with purified air for approximately 20 minutes. All components were thoroughly rinsed with deionized water until the specific conductance of the waste rinse water was less than $1 \mu \mathrm{S} / \mathrm{cm}$ (microsiemen per centimeter).

Water samples were processed in the USGS Massachusetts Water Science Center laboratory in Northborough, Massachusetts, at the conclusion of each sampling round or storm. For water samples collected during base-flow conditions when the flow and depth of water in the streams were small, the water generally was collected in the centroid of the stream in separate bottles designated for whole water, dissolved constituents, and organic compounds; therefore, only limited splitting was 
necessary at the laboratory. For water samples collected during storms, subsamples to be analyzed for inorganic and organic constituents were split directly from the 20L glass bottle by transferring the water with a Teflondiaphragm pump while the contents of the sample bottle were homogenized with a stainless-steel laboratory mixer. Water to be analyzed for dissolved inorganic constituents was filtered through a $600-\mathrm{cm}^{2}$ (square centimeter) capsule filter with a 0.45 -micrometer pore size. Water to be analyzed for dissolved caffeine, pesticides, and pesticide metabolites was filtered through a $142-\mathrm{mm}$ pre-combusted glass-fiber filter with a nominal $0.7-\mathrm{mm}$ pore diameter to remove suspended particulate matter. After the samples were processed, they were packed in ice and shipped overnight to the USGS National Water Quality Laboratory (NWQL), in Denver, Colorado, where they were analyzed for concentrations of dissolved calcium, sodium, chloride, sulfate, total nutrients, and polar pesticides and metabolites (American Public Health Association, 1998; Fishman, 1993; Fishman and Friedman, 1989; Furlong and others, 2001; Patton and Kryskalla, 2003).

The reliability of the chemical data was ensured by the preparation and analysis of several types of quality-control samples. These quality-control samples include 1 sourcesolution blank, 2 field blanks, 9 replicate samples, and 4 field-matrix spike samples and 2 replicate field-matrix spike samples. These analyses provided the basis for the interpretation of chemical data collected in the drinking-water source area.

Source-solution blanks were prepared from deionized water produced by a laboratory-grade water-purification system that uses ion-exchange packs and reverse osmosis. The source-solution water was stored in pre-cleaned glass bottles until it was subsequently used as blank water for the collection of field blanks.

A field blank is used to test for positive bias that can result from contamination during any stage of sample collection, processing, or analysis. One field blank was collected during sampling at base-flow conditions in April 2007 and another field blank was collected in preparation for the sampling of stormwater in July 2007. During collection of base-flow samples, the field blank was collected by transferring blank water from the holding bottle to the samplecollection bottles. It was then processed in a manner consistent with the collection of other environmental samples. The second field blank was collected by the automatic sampler in preparation for storm sampling. These samples were collected by pumping blank water through the automatic sampler tubing and into the collection bottle, and processing it in a manner consistent with the collection of environmental samples of stormwater.

Replicate samples are samples thought to be identical in composition to the environmental samples. Replicate samples provide a measure of bias and variability for the method of sample collection, sample processing (splitting, filtering, and preservation), and laboratory analysis, and for effects such as analyte degradation that can occur prior to laboratory analysis. A total of nine replicate samples were collected during base-flow conditions and during storms. Two replicate samples were collected to test for potential differences between samples collected manually and samples collected concurrently by automatic samplers. Five other replicate samples were collected manually during base-flow conditions. The remaining two replicates were collected during storms by independent automatic samplers that were triggered simultaneously. These replicates were used to test for potential differences between samples collected with the same method during periods of rapidly changing flow and water quality.

Field-matrix spikes are quality-control samples in which known amounts of target compounds are added to environmental replicate-split samples and then measured. The degree of recovery for each target analyte added to the environmental sample is used to determine the bias and variability attributed to the amount of degradation of target analytes during holding and shipment to the laboratory, the analytical method, and interferences contained in the environmental sample that mask or enhance determinations of the target analytes, or matrix effects. Replicate fieldmatrix spikes were also submitted to the NWQL for analysis. Similarly, known amounts of target compounds are added to replicate field-matrix spike samples. These samples are processed in the same manner as the field-matrix spike such that the samples are expected to be essentially identical in composition. Comparing the recovery of a field-matrix spike replicate to the recovery of the paired field-matrix spike provides a measure of the variability attributed to the aforementioned processes that can affect the concentration of each analyte.

In addition to the quality-assurance samples collected during this project, the NWQL routinely analyzes various quality-control samples, including laboratory reagent blanks, interference check solutions, laboratory control samples, standard reference materials, laboratory reagent spike samples, and laboratory duplicate samples to test and track method performance (Garbarino and others, 2006), and Furlong and others, 2001). The NWQL also adds surrogate compounds to all samples for determinations of pesticides and caffeine. Surrogate compounds, such as 2,4,5-T, caffeine-13C, and barban, are expected to perform similarly to the compounds being analyzed in the laboratory method. Because these compounds are not normally found in the environment, the recovery of the surrogate compounds can be used to qualify the performance of the analysis. When the difference between surrogate recoveries is outside acceptable control limits (usually low) as a result of an identified process failure, the results for the associated analytes are usually flagged by the NWQL with the "E" code (indicating an estimated value), or even deleted if the recovery is poor. Report levels may also be adjusted accordingly under some circumstances. 


\section{Data for the Cambridge Drinking-Water Source Area}

The data presented in this report can be used by the watershed managers in the city of Cambridge, Massachusetts to optimize the management of the drinking-water-supply reservoirs for water quality and quantity. The data allow clarification of the relation of reservoir management practices and current conditions to trends in the quantity and quality of water in the subbasins of the hydrologic system.

\section{Surface-Water Data}

From October 2006 through June 2007, monthly mean discharge from the Cambridge Reservoir accounted for less than 45 percent of the water entering the downstream Stony Brook Reservoir (fig. 2); this estimate was obtained by dividing the monthly mean discharges measured at USGS station 01104430 by the sum of monthly mean discharges measured at USGS stations 01104460 , and 01104475 (table 3). During this period, between 2 and 83 percent of the water entering the Stony Brook Reservoir was released to the Charles River (fig. 2); this estimate was obtained by dividing the sum of monthly mean reservoir outflows measured at USGS station 01104480 by the sum of monthly mean discharges measured at USGS stations 01104460 and 01104475 (table 3). From July through October 2007, the amount of water released from the Cambridge Reservoir accounted for about 80-95 percent of the total inflow to the Stony Brook Reservoir. The increase in discharge from the Cambridge Reservoir during the summer months is common as base flow from the upper portion of the Stony Brook Reservoir Basin (above the confluence with Hobbs Brook) diminishes and additional water is needed to meet the water demand for the city of Cambridge. However, low total rainfall (table 4) during this period increased the typical duration of the elevated flow discharged from the Cambridge Reservoir. About 3 percent or less of the water from the Stony Brook Reservoir was released to the Charles River for this period. As a result of increases in precipitation, monthly mean discharge from the Cambridge Reservoir was reduced to less than 45 percent of the water entering Stony Brook Reservoir (fig. 2) from November 2007 through September 2008. Flow released to the Charles River also increased to between 2 and 79 percent (fig. 2).

The volume of water released from the Stony Brook Reservoir to the Charles River during water year 2007 and 2008 represents an annual surplus of about 107 and 94 percent, respectively, of the total annual water demand by the city of Cambridge. During water years 1999-2006, this surplus has ranged from 29 to 155 percent if average demand is assumed to be $15 \mathrm{Mgal} / \mathrm{d}$.

Annual runoff is the total quantity of water that is discharged (runs off) from a drainage basin in a year.
The annual runoff for water year 2007 for USGS stations 01104415, 01104453, 01104455, and 01104475, which were unaffected by streamflow regulation, ranged from 0.91 to 1.28 millions of gallons of water per day per square mile $\left(\mathrm{Mgal} / \mathrm{d} / \mathrm{mi}^{2}\right.$; table 3). However, the annual runoff for USGS station 01104433 , another station unaffected by streamflow regulation, was $0.52 \mathrm{Mgal} / \mathrm{d} / \mathrm{mi}^{2}$ or about half the amount of the other stations (table 3 ). The low yield at USGS station 01104433 is likely the result of storm flows diverted to a neighboring intermittent stream caused by a backwater condition from a drainage pipe upstream of the monitoring station that limits the rate of flow. As a result of increases in the annual precipitation total for water year 2008 compared to 2007 (table 4), the annual runoff increased for USGS stations 01104415,01104455 , and 01104475 , ranging from 1.04 to $1.50 \mathrm{Mgal} / \mathrm{d} / \mathrm{mi}^{2}$ (table 3 ).

Monthly reservoir contents for the Cambridge Reservoir varied from about 30 to 95 percent of capacity during water years 2007-08 (fig. 3). The reservoir storage was at the 2007-08 minimum during the month of December 2007 and near the lowest level since water year 2002. The reservoir storage was near capacity in the spring of each water year, but was subsequently drawn down, particularly during the summer and fall of 2007, as additional water was needed to supplement the city of Cambridge water supply when the yield from the upper portion of the Stony Brook Reservoir Basin diminished. Monthly reservoir storage values for the Stony Brook Reservoir varied from about 47 to 91 percent of capacity during water years 2007-08 (fig. 3). Monthly reservoir storage for Fresh Pond Reservoir was maintained at greater than 92 percent of capacity during both water years (fig. 3).

\section{Specific Conductance Data}

Measurements of specific conductance for USGS stations in the Cambridge, Massachusetts drinking-water supply area are largely affected by the size of the stream and density of roads in each subbasin (Waldron and Bent, 2001). Monthly minimum and maximum specific-conductance values can vary substantially because of stormwater runoff, particularly in the small subbasins (table 5). Conversely, the monthly specific conductance variation for streamflow immediately downstream of the Cambridge and Stony Brook Reservoirs (table 5) is small because of the large volume of impounded water behind each reservoir.

Monthly mean specific-conductance values for USGS stations for water years 2007-08 were compared to available historical data (Smith, 2005, 2007; Socolow and others, 1999, 2000, 2001, 2002, 2003, 2004; U.S. Geological Survey, 2009). In general, most monthly mean specific-conductance values for all USGS stations were below the median monthly value for prior data, and for water year 2007, often were below the minimum monthly value for prior data (figs. 4-10). Monthly mean specific-conductance values for USGS station 01104415 for most of water year 2008 were within the interquartile 


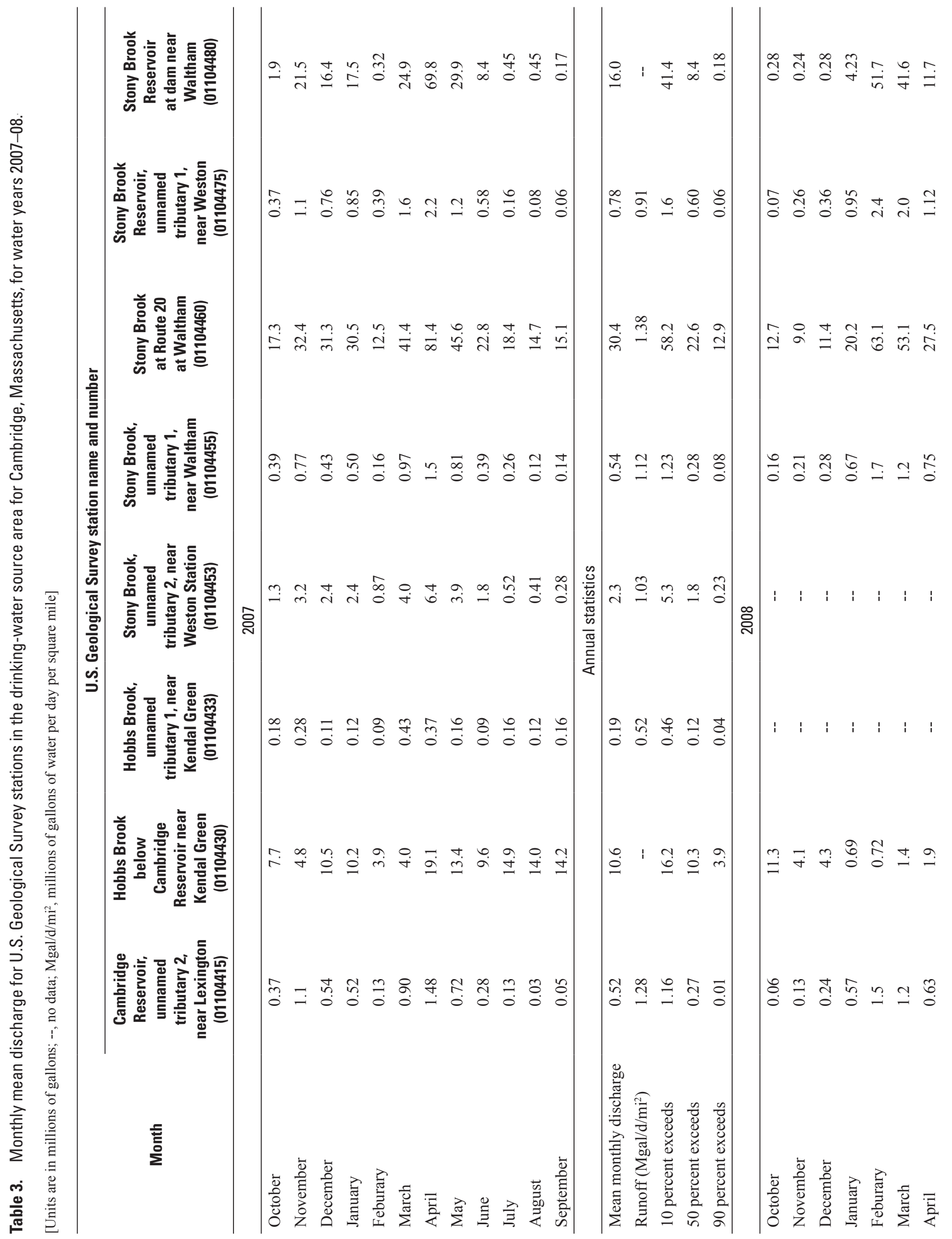




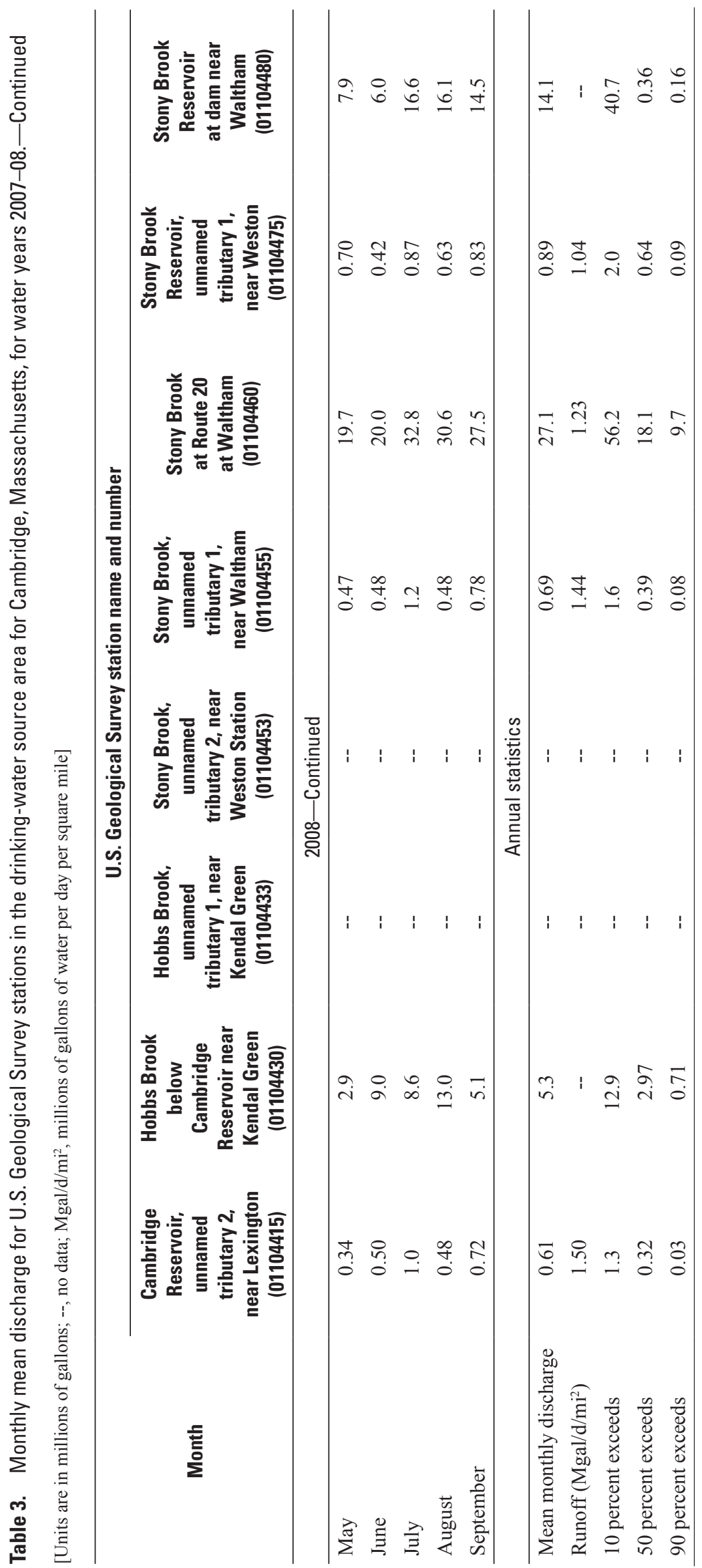




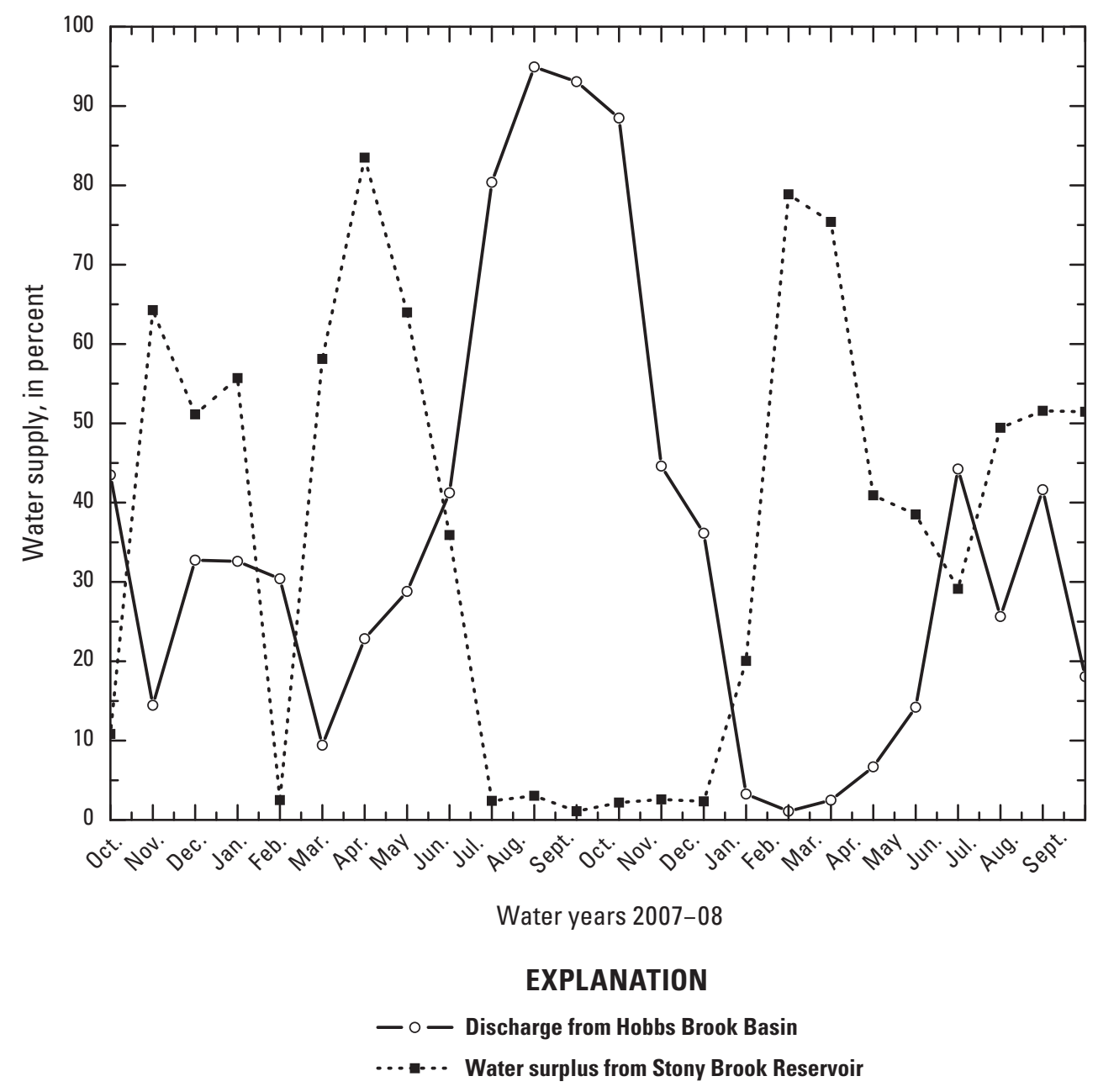

Figure 2. Discharge from the Cambridge Reservoir as a percentage of water entering the Stony Brook Reservoir, and discharge from the Stony Brook Reservoir to the Charles River as a percentage of total inflow to the Stony Brook Reservoir for water years 2007-08.

range (between the 25th and 75th percentile) of monthly specific conductance values for available data for the period from water year 1997 to water year 2007 (fig. 4), except for the month of December, which was greater than the prior maximum value; the month of January, which was between the 75th percentile and maximum value for prior data; and the months of July through September, which were less that the 25th percentile. The monthly mean specific-conductance values for streamflow for Hobbs Brook below the Cambridge Reservoir (USGS station 01104430) for December through February 2008 were greater than the prior maximum values; monthly mean specific-conductance values for March through July 2008 remained above the 75 th percentile for prior data; and monthly mean specific-conductance values decreased to within the interquartile range for August and September, 2008 (fig. 5). In part, the extreme specific conductance values were caused by the influx of high specific conductance water from the tributaries to the reservoir (for example, USGS station
01104415 ) and the low volume of water in the reservoir at the onset of the winter (fig. 11). As a result of nearly 62 in. of rainfall in the Cambridge Reservoir watershed during water year 2008 (table 4), the monthly mean specific-conductance values in streamflow below Cambridge Reservoir decreased to more typical levels (about $700 \mu \mathrm{s} / \mathrm{cm}$ ) by the end of the water year (fig. 5). Most monthly mean specific-conductance values for USGS station 01104455 for water year 2008 were within the interquartile range of the monthly mean specificconductance values for the prior water years, except for the values for December 2007, and May, June, and August 2008, which were greater than the 75th percentile value for prior data, and February 2008, which was below the 25th percentile value (fig. 7). Monthly mean specific-conductance values for the first four months of water year 2008 for USGS station 01104460 were greater that the 75 th percentile value for prior data (fig. 8). During this period, streamflow consisted largely of high specific conductance water from the Cambridge 
Table 4. Monthly and annual totals for precipitation for U.S. Geological Survey stations in the drinking-water source area for Cambridge, Massachusetts, for water years 2007-08.

[Units are in inches]

\begin{tabular}{|c|c|c|c|}
\hline Month of year & $\begin{array}{l}\text { Hobbs Brook below Cambridge } \\
\text { Reservoir near Kendal Green } \\
\text { (01104430) }\end{array}$ & $\begin{array}{l}\text { Stony Brook Reservoir } \\
\text { at dam near Waltham } \\
(01104480)\end{array}$ & $\begin{array}{c}\text { Fresh Pond gate house } \\
\text { at Cambridge } \\
\text { (422302071083801) }\end{array}$ \\
\hline \multicolumn{4}{|c|}{2007} \\
\hline October & 5.45 & 5.51 & 4.69 \\
\hline November & 6.75 & 6.58 & 6.32 \\
\hline December & 2.38 & 2.13 & 1.76 \\
\hline January & 2.72 & 2.69 & 2.28 \\
\hline Feburary & 2.32 & 2.17 & 2.08 \\
\hline March & 5.25 & 5.56 & 4.14 \\
\hline April & 7.61 & 7.89 & 7.43 \\
\hline May & 4.65 & 4.72 & 3.55 \\
\hline June & 2.56 & 2.94 & 1.98 \\
\hline July & 4.89 & 4.48 & 2.48 \\
\hline August & 0.69 & 0.97 & 0.71 \\
\hline September & 1.62 & 1.96 & 1.67 \\
\hline Annual totals & 46.89 & 47.60 & 39.09 \\
\hline \multicolumn{4}{|c|}{2008} \\
\hline October & 2.85 & 3.26 & 2.71 \\
\hline November & 3.54 & 3.45 & 2.73 \\
\hline December & 5.39 & 4.86 & 3.85 \\
\hline January & 2.88 & 2.69 & 2.5 \\
\hline Feburary & 8.94 & 8.73 & 7.79 \\
\hline March & 5.37 & 5.16 & 5.03 \\
\hline April & 4.54 & 4.98 & 3.98 \\
\hline May & 2.39 & 2.22 & 2.33 \\
\hline June & 5.37 & 5.14 & 4.19 \\
\hline July & 9.21 & 9.05 & 6.49 \\
\hline August & 3.32 & 3.30 & 4.33 \\
\hline September & 7.98 & 9.41 & 8.49 \\
\hline Annual totals & 61.78 & 62.25 & 54.42 \\
\hline
\end{tabular}

Reservoir (USGS station 01104430). For the remainder of water year 2008, most monthly mean specific-conductance values for USGS station 01104460 were less than the median monthly mean specific-conductance values for the prior water years (fig. 8).

Nearly all specific conductance values for USGS station 01104475 for water year 2008 were greater than the median value for 2004-07 data (fig. 9). The streamflow for this station has the lowest specific conductance of all USGS stations in the drinking-water supply area. Monthly mean specific-conductance values for this station ranged from 181 to $410 \mu \mathrm{s} / \mathrm{cm}$ for water years $2004-08$.
Most monthly mean specific-conductance values for the Fresh Pond Reservoir (USGS station 422302071083801) for water year 2008 were less than the median monthly mean specific-conductance values for the prior water years (2005-07), except for the values for October 2007, and February, March, and September 2008, which were greater than the prior median values (fig. 10). Monthly mean specific-conductance values for this station ranged from 422 to $733 \mu \mathrm{s} / \mathrm{cm}$ for water years $2005-08$. Annual peaks for monthly mean specific-conductance values for the Fresh Pond Reservoir that occur during late summer and fall (fig. 10) are due to a shift in water source. During most of the year, Fresh 


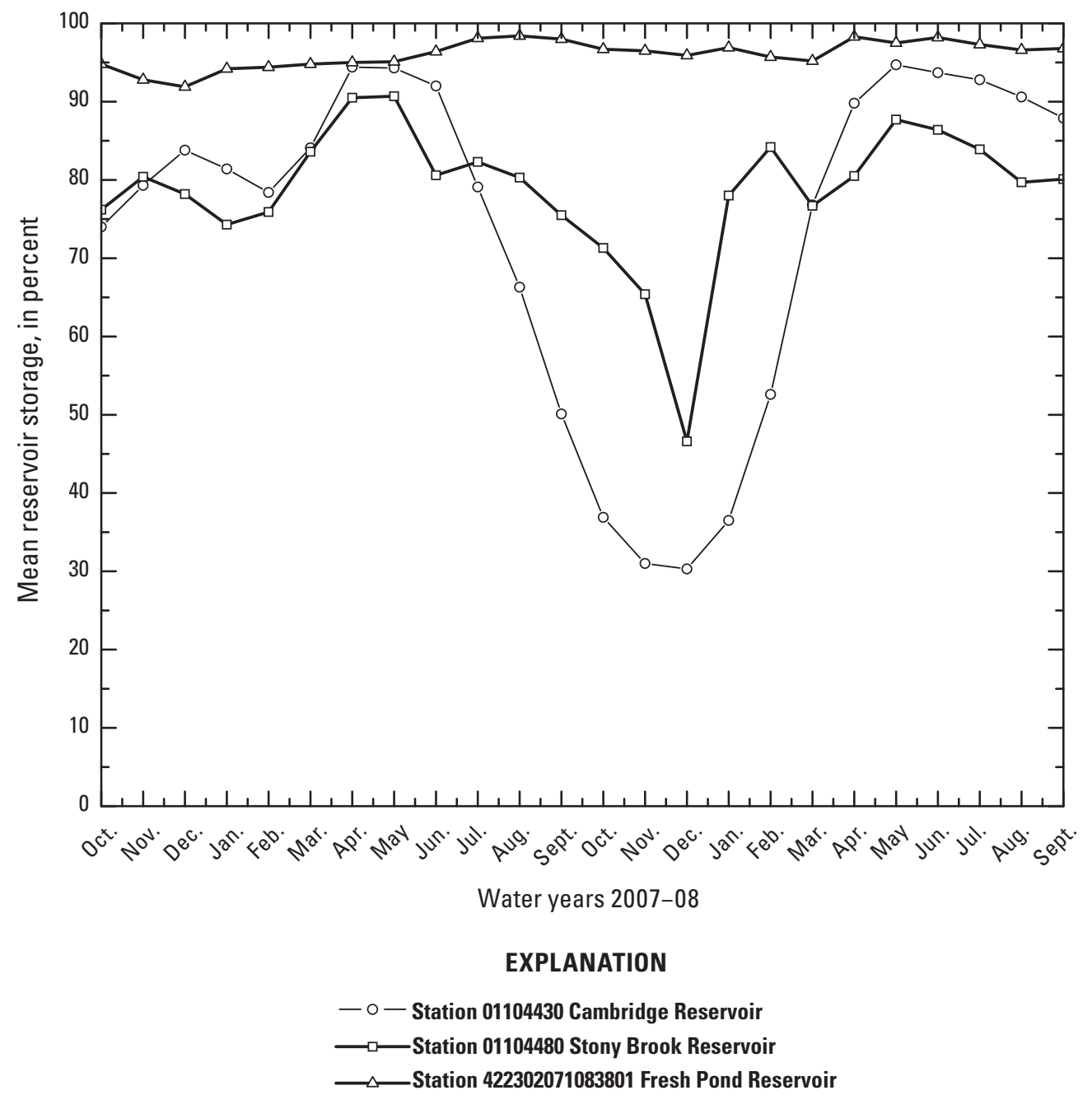

Figure 3. GMonthly mean reservoir storage as a percentage of capacity for water years 2007-08 for the Cambridge Reservoir, Stony Brook Reservoir, and the Fresh Pond Reservoir.

Pond Reservoir receives a mixture of water from sources with dissimilar specific conductances, namely, Hobbs Brook Basin and Stony Brook Reservoir Basin. However, as the water yield from the Stony Brook Reservoir Basin diminishes during the late summer and fall, the Cambridge Reservoir becomes the primary source of water for the Fresh Pond Reservoir. Similar trends in monthly mean specific-conductance values for Stony Brook (USGS station 01104460; fig. 8) often are recorded during the same months. The annual mean specific-conductance values for Fresh Pond Reservoir during water years 2007-08 were 483 and $497 \mu \mathrm{S} / \mathrm{cm}$, respectively (table 5), which were lower than the annual mean specificconductance range (514-553 $\mu \mathrm{S} / \mathrm{cm}$; Smith, 2005, 2007, 2008) for the prior three water years (2004-06).

Many of the small tributaries to the reservoirs differ from the primary streams in that both the quantity and quality of water in the tributaries respond more rapidly to stormwater runoff. The daily mean specific-conductance values for USGS stations 01104415,01104433 , and 01104455 differed by as much as 3 orders of magnitude from the annual mean values during water years 2007-08 (table 5). Daily mean specific conductance values for USGS station 01104475 had the smallest range between the minimum and maximum daily value, differing by about 1,300 and $1,900 \mu \mathrm{S} / \mathrm{cm}$, or about 530 and 595 percent of the mean annual value during water years 2007 and 2008, respectively. Daily mean specific conductance values for USGS station 01104455 had the greatest range, differing by about 34,300 and $98,500 \mu \mathrm{S} / \mathrm{cm}$, or about 3,150 and 6,480 percent, of the mean annual value during water years 2007 and 2008, respectively. The coefficient of variation (COV; the standard deviation divided by the mean) for monthly mean specific-conductance values for water year 2007 ranged from about 15 percent to about 38 percent $(01104455>01104433>01104415>01104475)$. The COV 


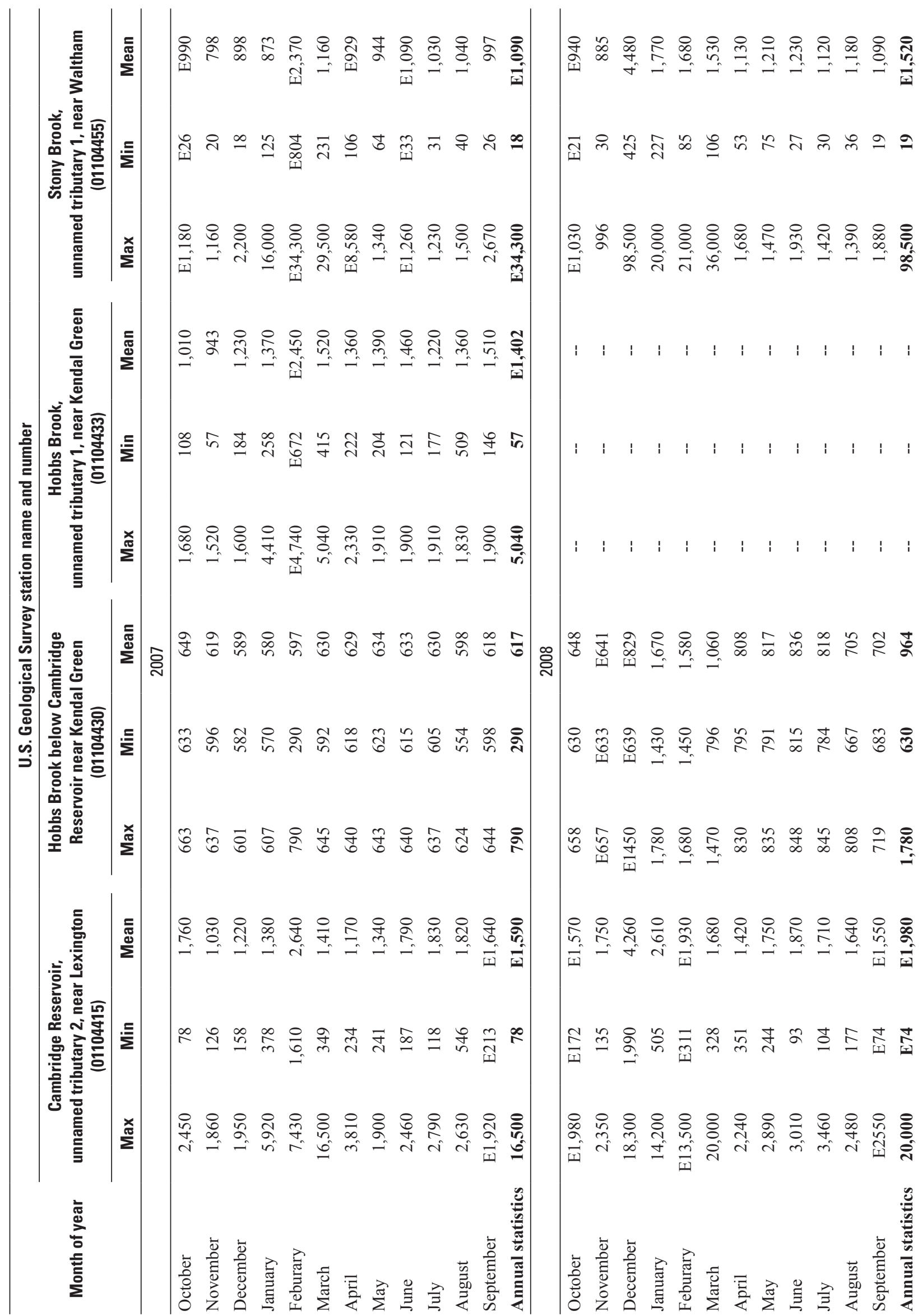




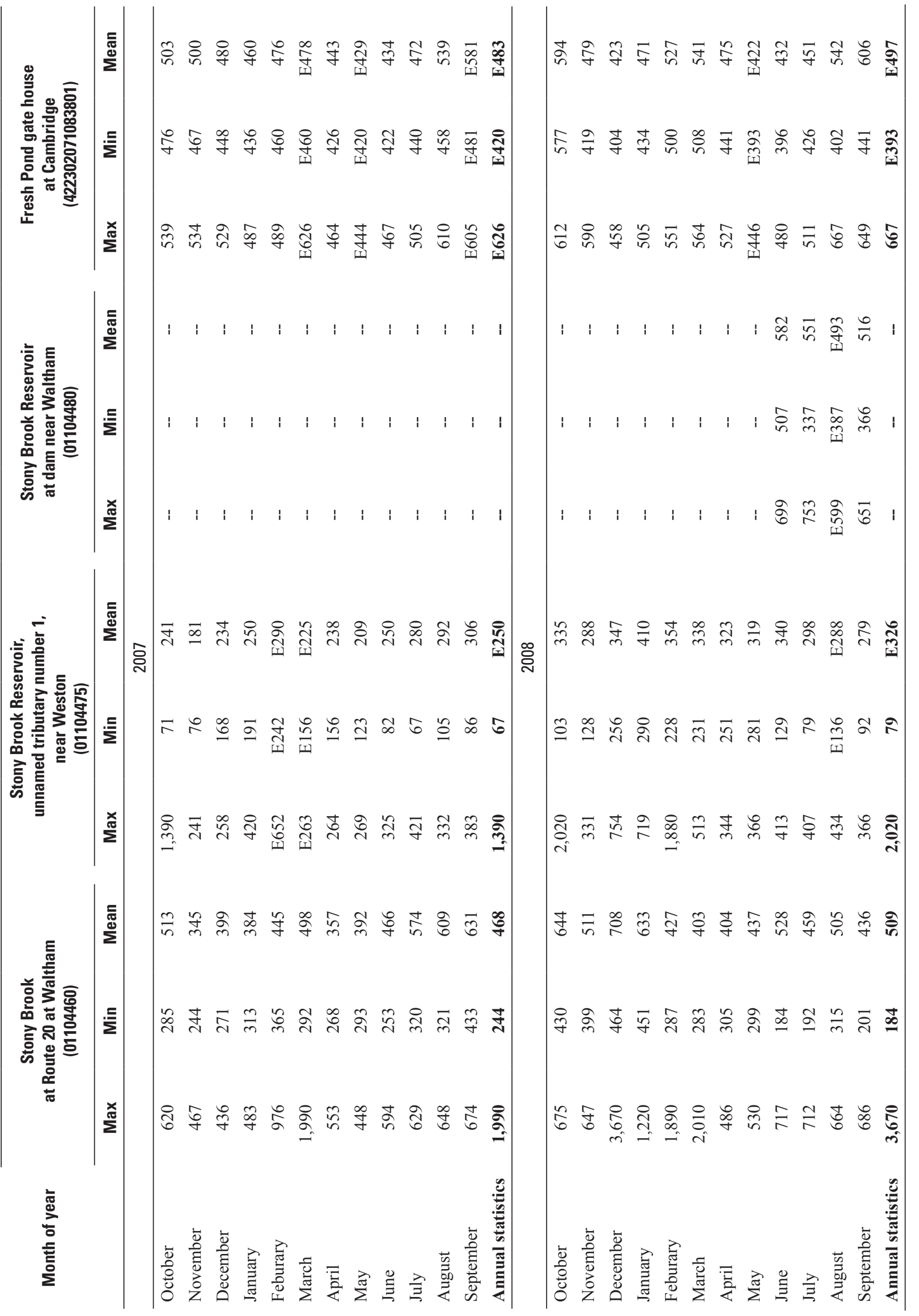




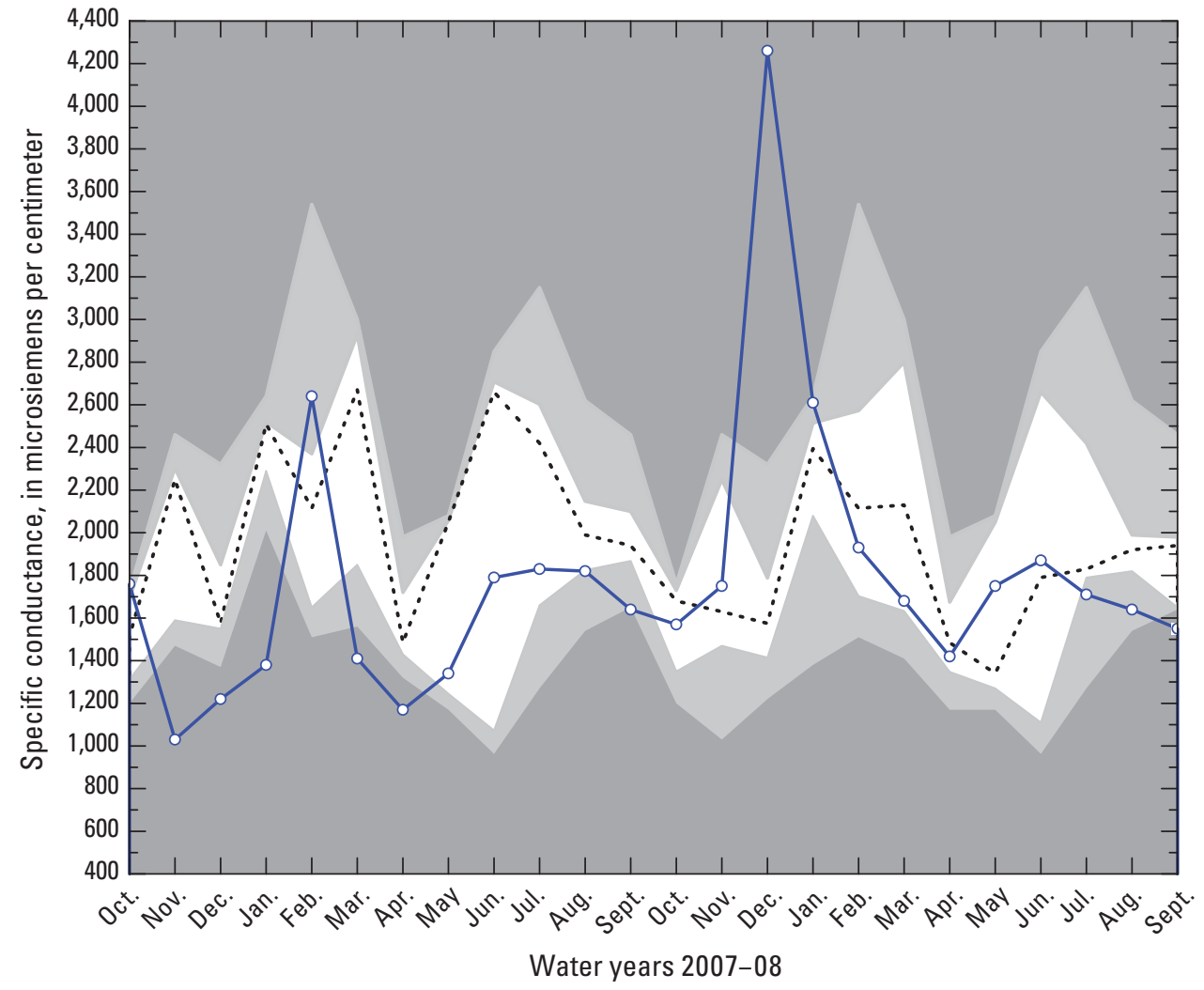

\section{EXPLANATION}

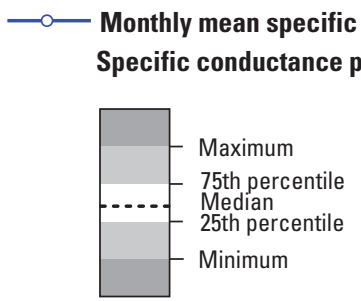

Figure 4. Comparison of specific conductance for water years 2007-08 to prior specific conductance data for U.S. Geological Survey station 01104415, Cambridge Reservoir, unnamed tributary number 2, near Lexington, Massachusetts. 


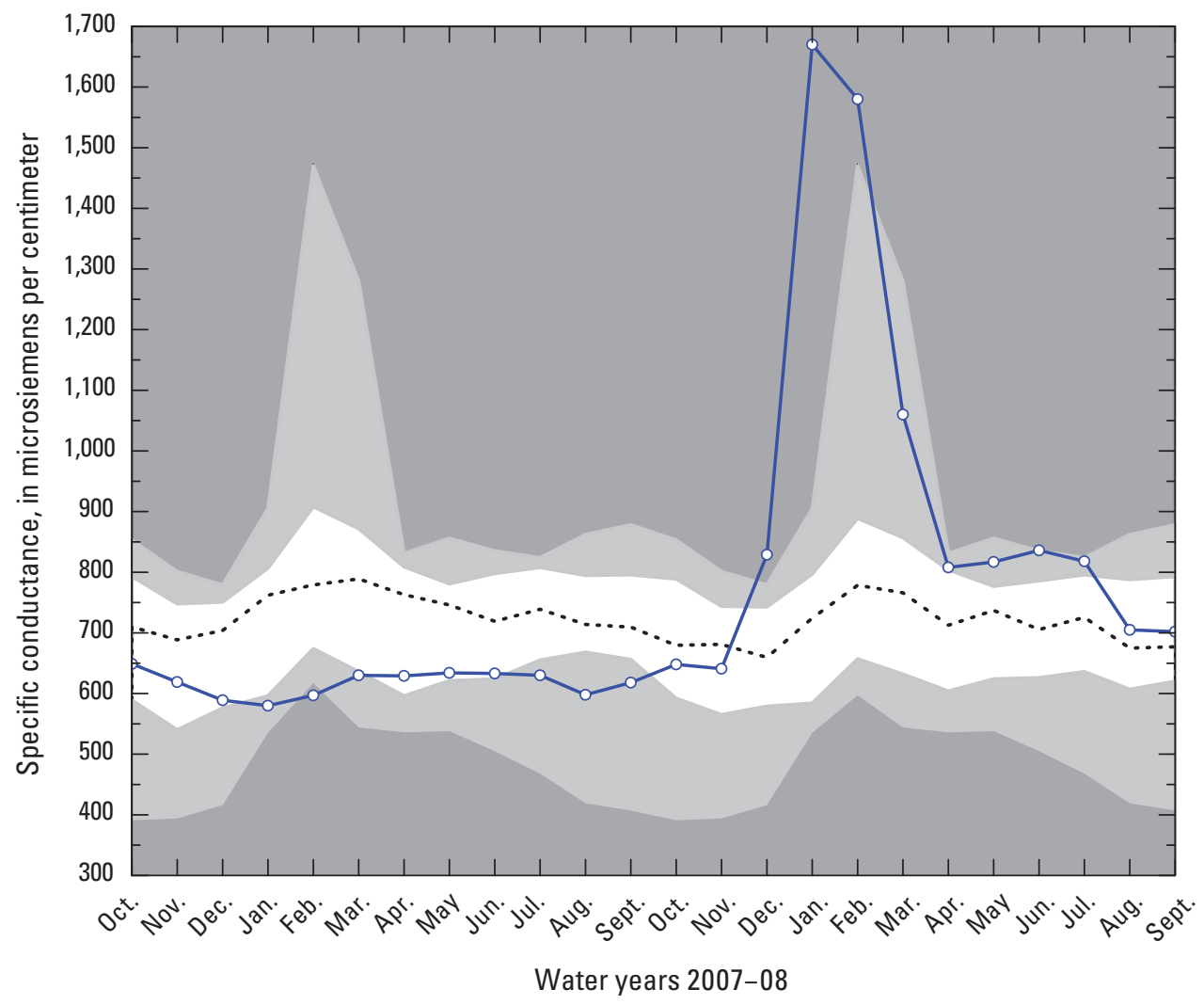

EXPLANATION

- - Monthly mean specific conductance for water years 2007-08 Specific conductance prior to date shown for water years 1998-07

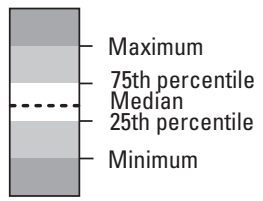

Figure 5. Comparison of specific conductance for water years 2007-08 for U.S. Geological Survey station 01104430, Hobbs Brook below Cambridge Reservoir near Kendal Green, Massachusetts. 


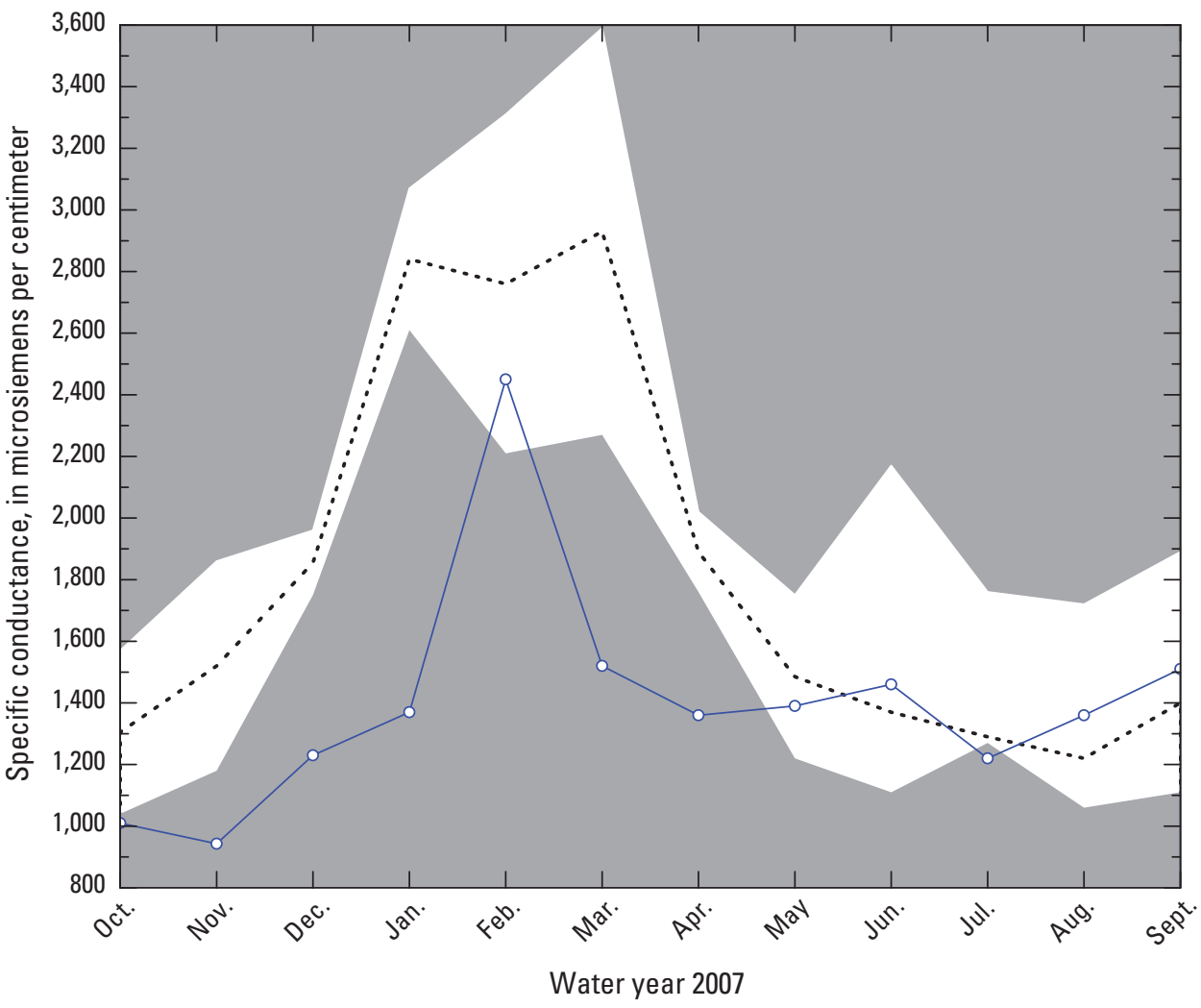

EXPLANATION

- Monthly mean specific conductance for water years 2007

Specific conductance prior to date shown for water years 2004-06

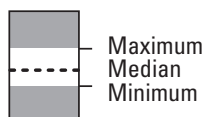

Figure 6. Comparison of specific conductance for water year 2007 for U.S. Geological Survey station 01104433, Hobbs Brook unnamed tributary number 1, near Kendal Green, Massachusetts. 


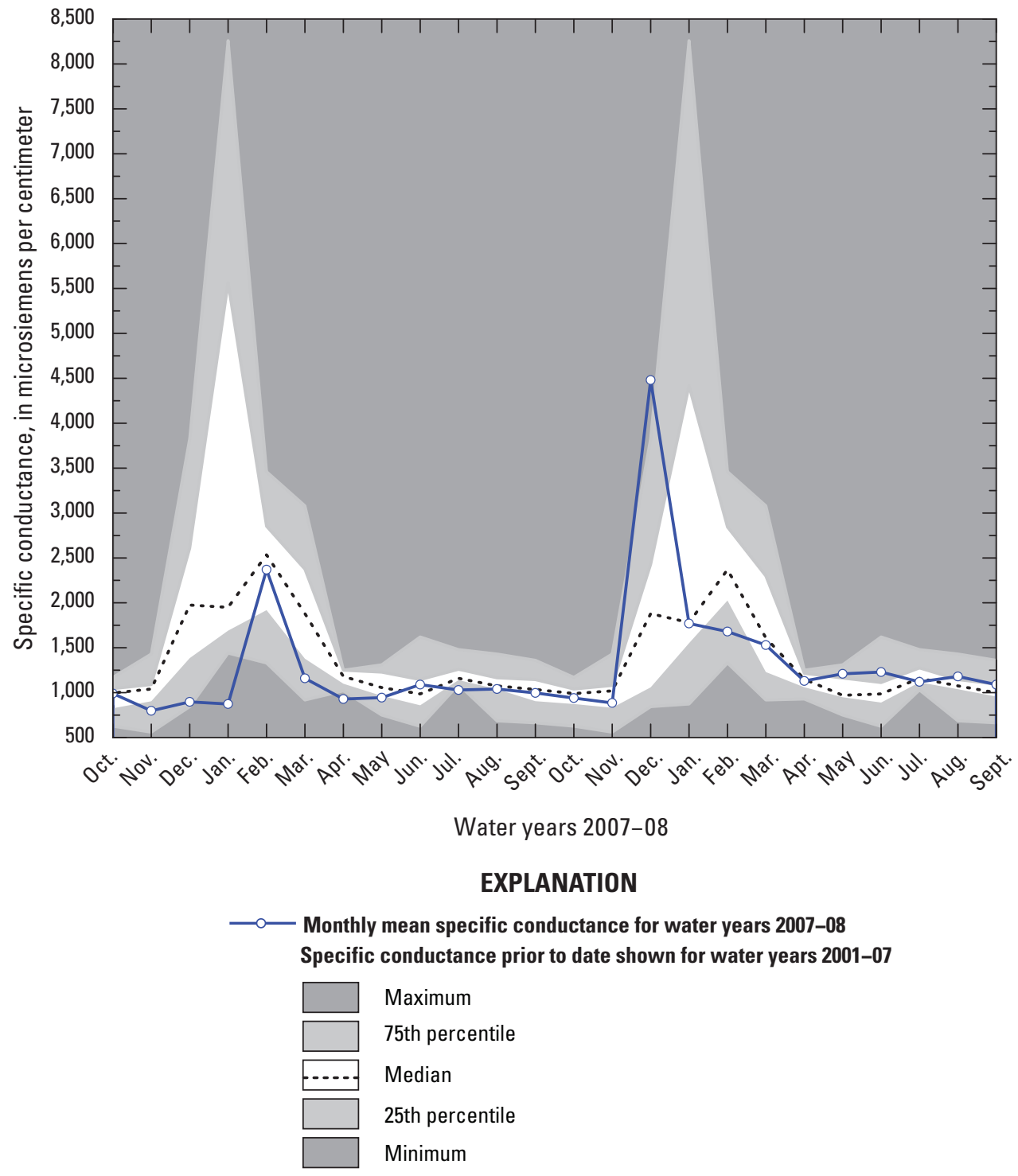

Figure 7. Comparison of specific conductance for water years 2007-08 for U.S. Geological Survey station 01104455, Stony Brook, unnamed tributary number 1, near Waltham, Massachusetts. 


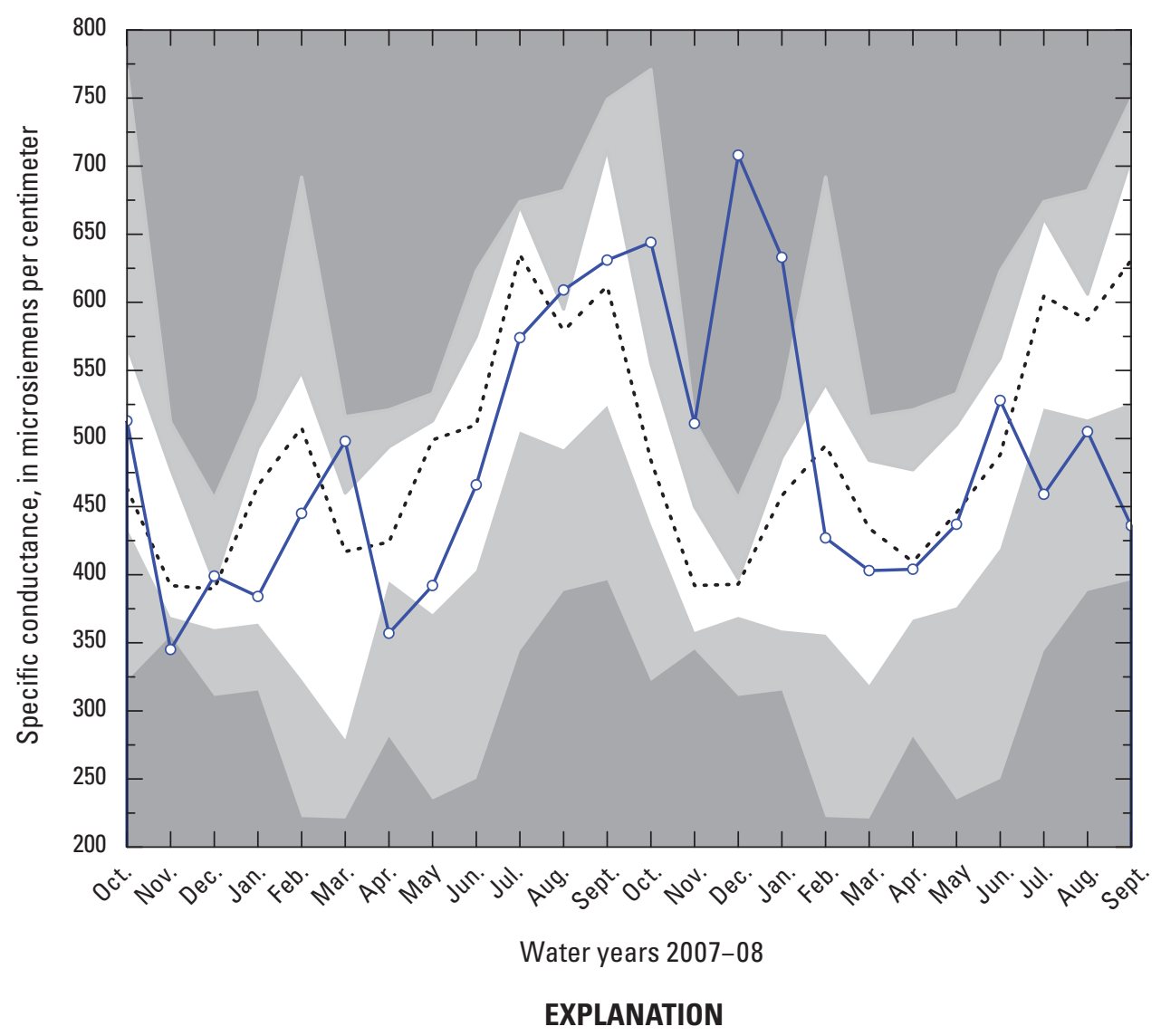

- Monthly mean specific conductance for water years 2007-08 Specific conductance prior to date shown for water years 1998, and 2002-07

\begin{tabular}{|l|l}
\hline & Maximum \\
\hline & 75th percentile \\
\hline$\ldots n$ & Median \\
\hline & 25th percentile \\
\hline & Minimum
\end{tabular}

Figure 8. Comparison of specific conductance for water years 2007-08 for U.S. Geological Survey station 01104460, Stony Brook at Route 20 at Waltham, Massachusetts. 


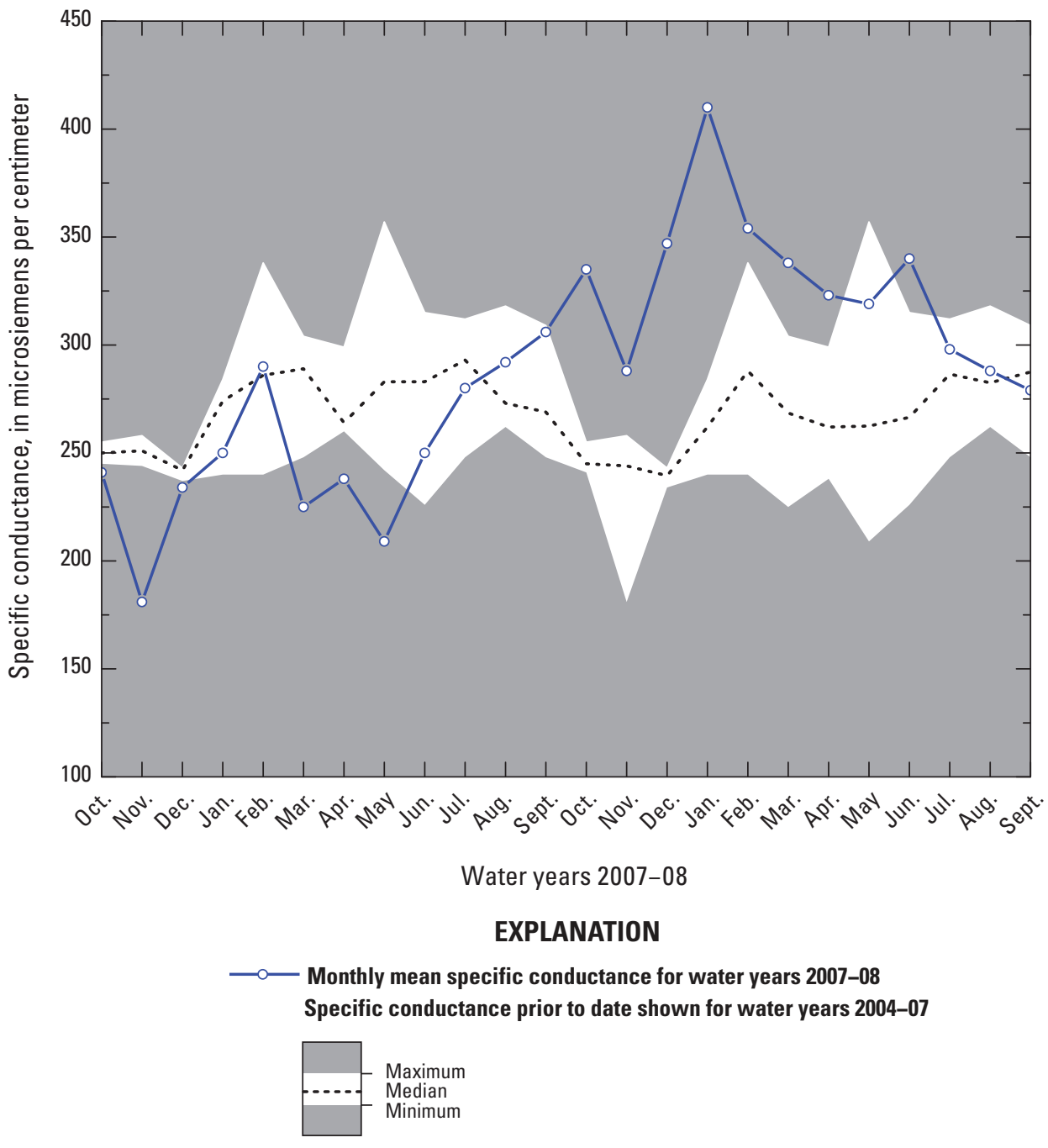

Figure 9. Comparison of specific conductance for water years 2007-08 for U.S.

Geological Survey station 01104475, Stony Brook Reservoir, unnamed tributary number 1, near Weston, Massachusetts. 


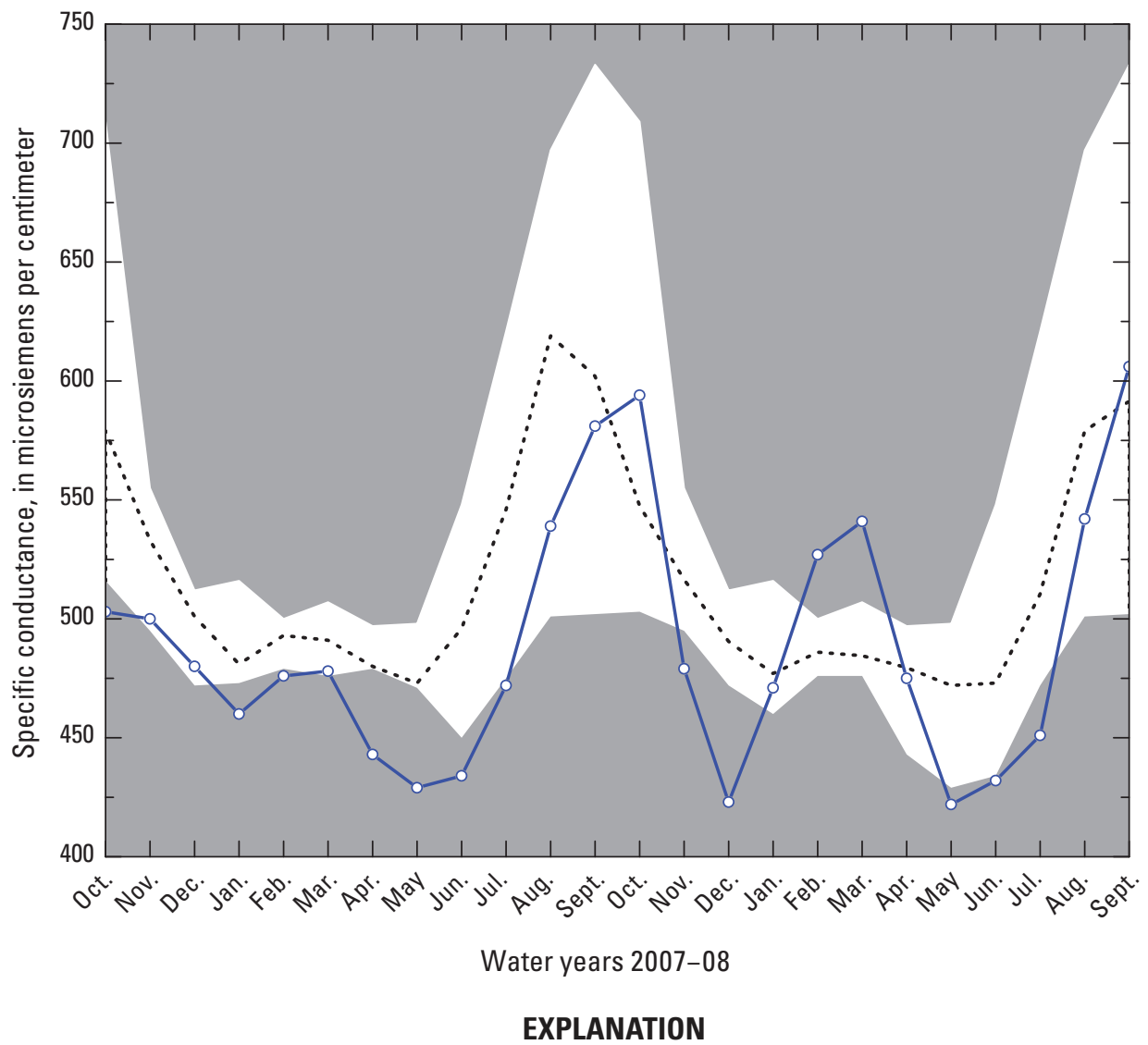

- Monthly mean spe
Specific conducta
\begin{tabular}{|l|l}
\hline & Maximum \\
\hdashline & Median \\
Minimum
\end{tabular}

Figure 10. Comparison of specific conductance for water years 2007-08 for U.S.

Geological Survey station 422302071083801, Fresh Pond in Gate House at Cambridge, Massachusetts. 


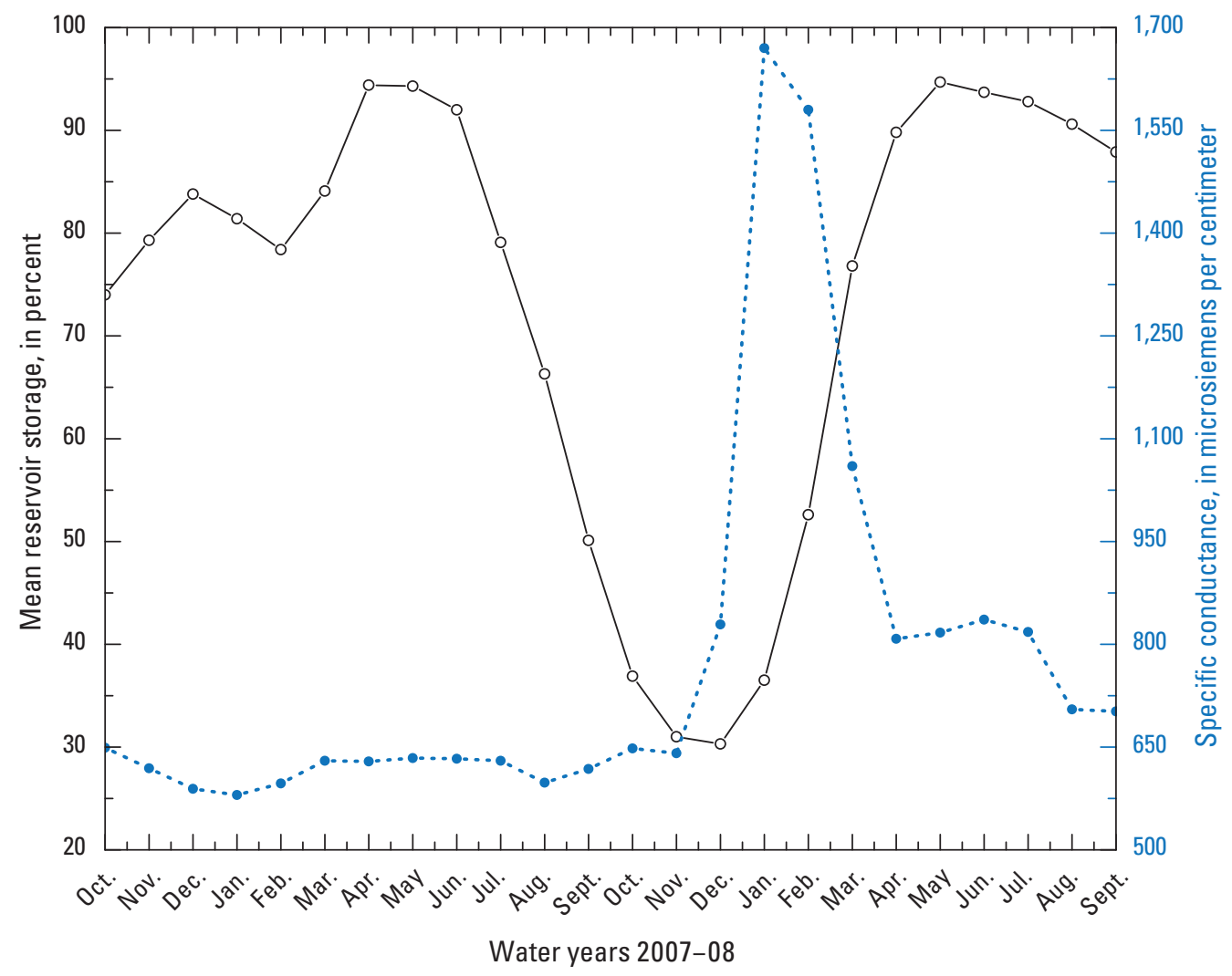

\section{EXPLANATION}

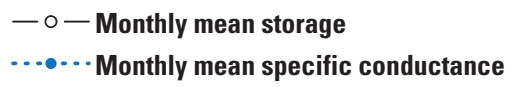

Figure 11. Monthly mean reservoir storage as a percentage of capacity and specific conductance for water years 2007-08 for U.S. Geological Survey station 01104430, Hobbs Brook below Cambridge Reservoir, near Kendal Green, Massachusetts.

for monthly mean specific-conductance values for water year 2008 ranged from about 11 percent to about 64 percent $(01104455>01104415>01104475)$.

\section{Water-Quality Data}

The physical properties and chemical concentrations for water samples were compared to the U.S. Environmental Protection Agency (USEPA; U.S. Environmental Protection Agency, 2007) secondary drinking-water standards, where available, and the Massachusetts drinking-water guideline for sodium (Commonwealth of Massachusetts, Executive Office of Energy and Environmental Affairs, Department of Environmental Protection, Office of Research and Standards, 2009). Secondary drinking-water regulations are nonmandatory water-quality standards established by the USEPA. They are guidelines designed to assist public water suppliers in managing their drinking water for aesthetic considerations, such as taste, odor, color, foaming, corrosivity, staining, scaling, and sedimentation. These constituents do not present a risk to human health at the secondary maximum contaminant level (U.S. Environmental Protection Agency, 2007). Although these standards are typically applied to finished water, the presence of these constituents in concentrations that exceed the respective standards can damage water equipment or reduce the effectiveness of treatment for other contaminants. Some constituents, such as chloride, sodium, and nitrogen, cannot be effectively removed or reduced by the Cambridge water-treatment facility (Smith, 2007).

In 3 of 81 water samples, measurements of $\mathrm{pH}$ were less than the USEPA secondary drinking-water standard of $6.5 \mathrm{pH}$ units. These measurements (each $6.4 \mathrm{pH}$ units) were made in one water sample collected at USGS station 01104420 during base-flow conditions and in two composite samples of stormwater collected at USGS station 01104455 (table 6, at end of report). Concentrations of dissolved chloride in all water samples collected during base-flow conditions from USGS stations 01104410, 01104415, 01104420, 01104433, 
and 01104455 were near or exceeded the USEPA secondary drinking-water standard of $250 \mathrm{mg} / \mathrm{L}$ (milligrams per liter). The 504-mg/L chloride concentration measured in a water sample collected from the USGS station below the Cambridge Reservoir (01104430) on January 31, 2008, was the highest concentration measured at that station by the USGS between water years 1997-2008 (Smith, 2008). All samples collected during base-flow conditions at USGS stations 01104415 and 01104433, and five of six samples collected at USGS station 01104455 exceeded the secondary drinking-water standard for chloride (table 6). The concentration of chloride in stormwater also exceeded the standard in two of six composite samples at USGS station 01104415, in two of nine composite samples of at USGS 01104455, and for a single composite sample collected at USGS station 01104433 (table 6). Concentrations of dissolved sulfate in all water samples were below the USEPA secondary drinking-water standard of $250 \mathrm{mg} / \mathrm{L}$. Concentrations of dissolved sodium for all samples collected in the drinking-water source area exceeded the Massachusetts drinking water guideline of $20 \mathrm{mg} / \mathrm{L}$, with the exception of three composites samples of stormwater collected at USGS stations 01104455 and 01104475 (table 6).

Concentrations of dissolved calcium, sodium, chloride, and sulfate in water samples collected in the drinking-water source area (excluding Fresh Pond Reservoir) ranged from 2.99 to $75.8 \mathrm{mg} / \mathrm{L}, 7.47$ to $534 \mathrm{mg} / \mathrm{L}, 11.4$ to $1,050 \mathrm{mg} / \mathrm{L}$, and 2.85 to $47.2 \mathrm{mg} / \mathrm{L}$, respectively (table 6). With a few exceptions, the concentrations of these constituents in water samples collected during storms from the tributaries were generally lower than the concentrations observed in water samples collected during base-flow conditions at the primary sampling stations. The highest concentrations of dissolved sodium $(534 \mathrm{mg} / \mathrm{L})$, chloride $(1,050 \mathrm{mg} / \mathrm{L})$, and sulfate $(47.2 \mathrm{mg} / \mathrm{L})$ were found in a water sample collected on March 2,2007 , during a winter storm at USGS station 01104415 . The highest concentration of dissolved calcium $(75.8 \mathrm{mg} / \mathrm{L})$ was measured in a water sample collected on April 11, 2007, at USGS station 01104433 during base-flow conditions.

The concentration of total nitrogen in water samples for all subbasins ranged from 0.42 to $3.14 \mathrm{mg} / \mathrm{L}$ (table 6). Average total nitrogen concentrations in water samples for the tributaries at the primary sampling sites ranged from 1.67 to $2.21 \mathrm{mg} / \mathrm{L}$. For samples collected at USGS station 01104460 , the average concentration of total nitrogen in water samples collected during base-flow conditions was similar (within $0.05 \mathrm{mg} / \mathrm{L}$ ) to the average concentration of total nitrogen in composite samples of stormwater; however, the difference between average concentrations of total nitrogen in samples of base flow and stormwater for the tributaries ranged from -0.57 to $0.53 \mathrm{mg} / \mathrm{L}$. The highest concentration of total nitrogen $(3.14 \mathrm{mg} / \mathrm{L})$ was measured in a water sample collected on March 2, 2007, in a composite sample of stormwater at USGS station 01104415, and on September 25, 2007, in a sample of water collected during base-flow conditions at USGS station 01104475. The average concentration of total nitrogen for samples collected during base-flow conditions at all of the sampling locations in the drinking-water source area (fig. 1) ranged from $0.50 \mathrm{mg} / \mathrm{L}$ at USGS station 01104410 to $2.07 \mathrm{mg} / \mathrm{L}$ at USGS station $01104475(01104410<01104430<0$ $1104405<01104460<01104420<01104390<01104453<011044$ $15<01104433<01104455<01104475$ ).

The concentration of total phosphorus in water samples for all subbasins ranged from 0.006 to $0.53 \mathrm{mg} / \mathrm{L}$ (table 6). Average phosphorus concentrations in water samples for the tributaries at the primary sampling sites ranged from 0.087 to $0.125 \mathrm{mg} / \mathrm{L}$. For samples collected at USGS station 01104460 , the average concentration of total phosphorus in water samples collected during base-flow conditions was similar (within $0.034 \mathrm{mg} / \mathrm{L}$ ) to the average concentration of phosphorus in composite samples of stormwater at USGS station 01104460; however, the difference between average concentrations of total phosphorus in samples of base flow and stormwater for the tributaries ranged from about 0.10 to $0.23 \mathrm{mg} / \mathrm{L}$. The highest concentration of total phosphorus $(0.53 \mathrm{mg} / \mathrm{L})$ was measured in a composite sample of water collected during a storm on March 2, 2007, at USGS station 01104415 (table 6). The average concentration of total phosphorus for samples collected during base-flow conditions at all of the sampling locations (fig. 1) in the drinking-water source area ranged from $0.008 \mathrm{mg} / \mathrm{L}$ at USGS station 01104455 to $0.041 \mathrm{mg} / \mathrm{L}$ at USGS station $01104433(01104455<01104415<01104430<01$ $104475<01104410<01104460<01104390<01104453<0110442$ $0<01104405<01104433$ ).

Eighteen pesticides and caffeine were detected in water samples (table 6) collected in the primary streams and tributaries to the Cambridge Reservoir and Stony Brook Reservoir, and in raw water collected from the Cambridge water-treatment facility intake from the Fresh Pond Reservoir in water years 2007-08. Most of these pesticides are found in over-the-counter products used for turf management and the treatment of ornamental shrubs (table 7). Caffeine was detected in 54 percent of 80 water samples at concentrations ranging from 0.004 to $0.557 \mu \mathrm{g} / \mathrm{L}$ (micrograms per liter). Caffeine was detected in water samples collected at all USGS sampling stations except for 01104390, 01104410, and 01104453 . Imidacloprid, siduron, and norflurazon were the most frequently detected pesticides (table 8 ) in samples of water collected in the drinking-water source area, with the number of detections ranging from about 29 to 32 percent. Caffeine and 2,4-D were more frequently detected in water samples collected during storms than in water samples collected during base-flow conditions (table 8). Imidacloprid, siduron, and 2,4-D were the only widespread pesticides detected in water samples collected at primary sampling stations (fig. 1 and table 8). The herbicide norflurazon was detected in nearly all water samples collected at USGS station 01104455. The herbicide siduron; the insecticides carbaryl and imidacloprid; and the fungicides benomyl, metalaxyl, and propiconazole were detected in water samples collected under base-flow and stormflow conditions at USGS station 01104475 at a frequency equal to or greater than 50 percent (table 8). 
Table 7. Characteristics of selected pesticides detected in samples of base-flow and stormflow collected in the Hobbs Brook and Stony Brook Reservoir Basins, Massachusetts, water years 2007-08.

[CAS, Chemical Abstracts Service]

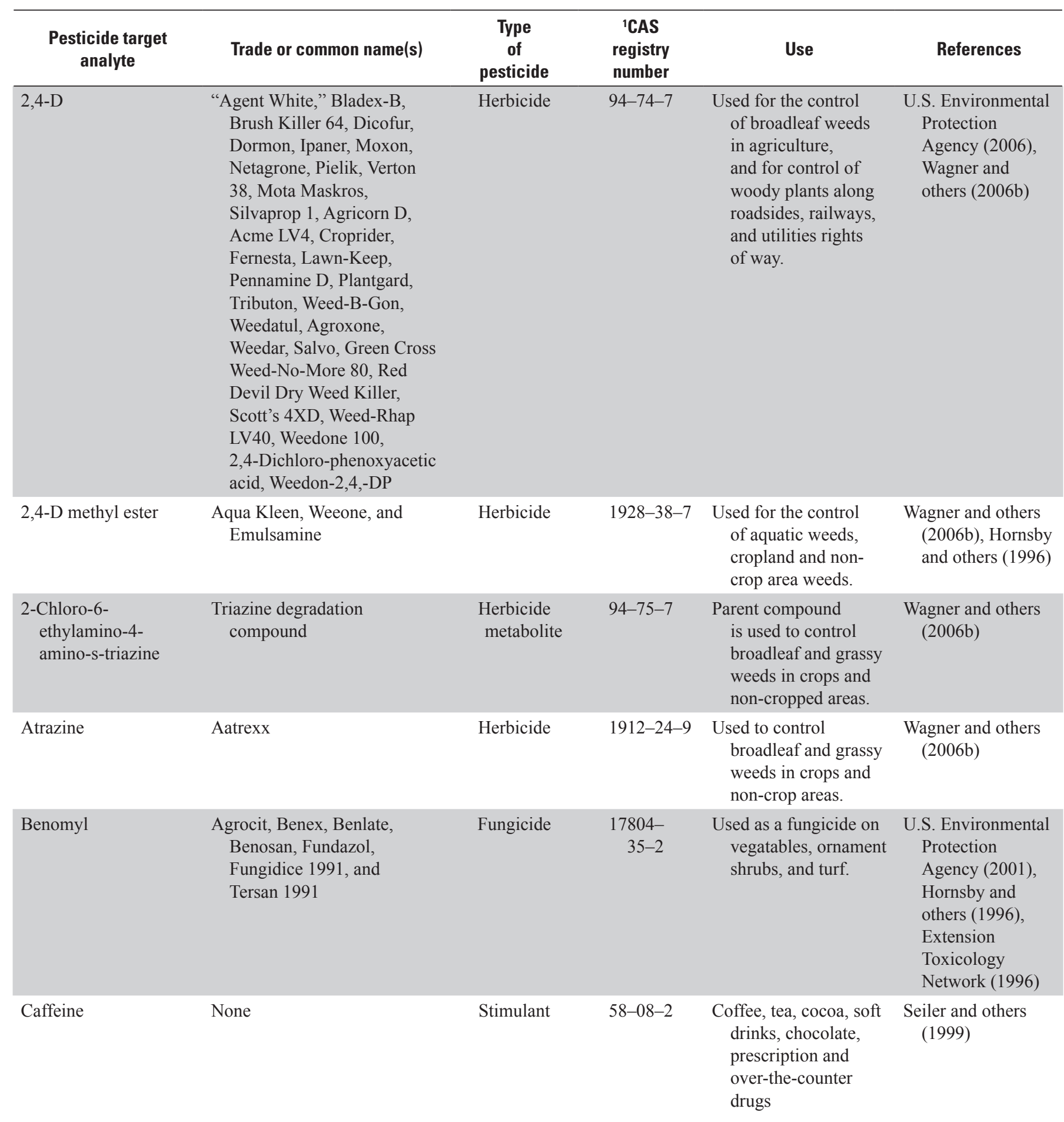


Table 7. Characteristics of selected pesticides detected in samples of base-flow and stormflow collected in the Hobbs Brook and Stony Brook Reservoir Basins, Massachusetts, water years 2007-08.-Continued

[CAS, Chemical Abstracts Service]

\begin{tabular}{|c|c|c|c|c|c|}
\hline $\begin{array}{l}\text { Pesticide target } \\
\text { analyte }\end{array}$ & Trade or common name(s) & $\begin{array}{l}\text { Type } \\
\text { of } \\
\text { pesticide }\end{array}$ & $\begin{array}{l}{ }^{1} \mathrm{CAS} \\
\text { registry } \\
\text { number }\end{array}$ & Use & References \\
\hline Carbaryl & Ortho Seven, Sevin & Insecticide & $63-25-2$ & $\begin{array}{l}\text { Used as a broad- } \\
\text { spectrum insecticide } \\
\text { in agriculture, } \\
\text { professional turf } \\
\text { management } \\
\text { and ornamental } \\
\text { production, and } \\
\text { residential lawns } \\
\text { and gardens. }\end{array}$ & $\begin{array}{l}\text { U.S. Environmental } \\
\text { Protection } \\
\text { Agency (2004a), } \\
\text { Hornsby and } \\
\text { others (1996) }\end{array}$ \\
\hline Dinoseb & $\begin{array}{l}\text { Basanite, Caldon, Chemox, } \\
\text { Chemsect DNBP, Dinitro, } \\
\text { Dynamyte, Elgetol, } \\
\text { Gebutox, Hel- Fire, Kiloseb, } \\
\text { Nitropone, Premerge, Sinox } \\
\text { General, Subitex, and Vertac } \\
\text { Weed Killer. }\end{array}$ & Herbicide & $88-85-7$ & $\begin{array}{l}\text { Used in field crops } \\
\text { for the selective } \\
\text { control of grass and } \\
\text { broadleaf weeds } \\
\text { in corn; also used } \\
\text { as an insecticide in } \\
\text { grapes; and as a seed } \\
\text { crop drying agent. } \\
\text { Sale discontinued in } \\
\text { 1986. }\end{array}$ & $\begin{array}{l}\text { Wagner and others } \\
\text { (2006b), Hornsby } \\
\text { and others } \\
\text { (1996), Extension } \\
\text { Toxicology } \\
\text { Network (1993a) }\end{array}$ \\
\hline Diuron & $\begin{array}{l}\text { Aguton, DCMU, Di-on, Direx, } \\
\text { Karmex, Topsite }\end{array}$ & Herbicide & $330-54-1$ & $\begin{array}{l}\text { Used for the control of } \\
\text { weeds and mosses } \\
\text { on turf and on } \\
\text { many crops. }\end{array}$ & $\begin{array}{l}\text { Wagner and others } \\
\text { (2006b), Hornsby } \\
\text { and others } \\
\text { (1996), Extension } \\
\text { Toxicology } \\
\text { Network (1993b) }\end{array}$ \\
\hline Fenuron & Dybar, Beet-Kleen & Herbicide & $101-42-8$ & $\begin{array}{l}\text { Used on leeks, fruits, } \\
\text { and nursery trees. }\end{array}$ & $\begin{array}{l}\text { Wagner and others } \\
\text { (2006b), Hornsby } \\
\text { and others (1996) }\end{array}$ \\
\hline $\begin{array}{l}\text { 2-methyl-4- } \\
\text { chlorophenoxyacetic } \\
\text { acid (MCPA) }\end{array}$ & $\begin{array}{l}\text { Agritox, Agroxone, Border } \\
\text { Master, Chiptox, Metaxon, } \\
\text { Rhomene, Rhonox, Weed- } \\
\text { Rhap, Weedone, Weedar }\end{array}$ & Herbicide & $94-74-6$ & $\begin{array}{l}\text { Used for selective } \\
\text { control of broadleaf } \\
\text { weeds on turf, } \\
\text { lawns, vines, and } \\
\text { rights-of-way, and in } \\
\text { forestry applications. }\end{array}$ & $\begin{array}{l}\text { Wagner and others } \\
\text { (2006b), U.S. } \\
\text { Environmental } \\
\text { Protection } \\
\text { Agency (2004b), } \\
\text { Hornsby and } \\
\text { others (1996), } \\
\text { Extension } \\
\text { Toxicology } \\
\text { Network (1993c) }\end{array}$ \\
\hline
\end{tabular}


Table 7. Characteristics of selected pesticides detected in samples of base-flow and stormflow collected in the Hobbs Brook and Stony Brook Reservoir Basins, Massachusetts, water years 2007-08.—Continued

[CAS, Chemical Abstracts Service]

\begin{tabular}{|c|c|c|c|c|c|}
\hline $\begin{array}{l}\text { Pesticide target } \\
\text { analyte }\end{array}$ & Trade or common name(s) & $\begin{array}{c}\text { Type } \\
\text { of } \\
\text { pesticide }\end{array}$ & $\begin{array}{l}{ }^{1} \mathrm{CAS} \\
\text { registry } \\
\text { number }\end{array}$ & Use & References \\
\hline Metalaxyl & $\begin{array}{l}\text { Ridomil, Apron, Delta-Coat } \\
\text { AD, Subdue 2E }\end{array}$ & Fungicide & $\begin{array}{r}57837- \\
19-1\end{array}$ & $\begin{array}{l}\text { Controls plant diseases } \\
\text { caused by water- } \\
\text { mold fungi. Used } \\
\text { on crops, ornament } \\
\text { shrubs and trees, } \\
\text { and turf. }\end{array}$ & $\begin{array}{l}\text { Wagner and others } \\
\text { (2006b), Hornsby } \\
\text { and others } \\
\text { (1996), U.S. } \\
\text { Environmental } \\
\text { Protection } \\
\text { Agency (1994), } \\
\text { Extension } \\
\text { Toxicology } \\
\text { Network (1993d) }\end{array}$ \\
\hline Norflurazon & Zorial, Solicam, Evital & Herbicide & $\begin{array}{r}27314- \\
13-2\end{array}$ & $\begin{array}{l}\text { Used for the control } \\
\text { of germinating } \\
\text { annual grasses and } \\
\text { broadleaf weeds } \\
\text { in agricultural, } \\
\text { nonagricultural, and } \\
\text { industrial areas. }\end{array}$ & $\begin{array}{l}\text { Wagner and others } \\
\text { (2006b), U.S. } \\
\text { Environmental } \\
\text { Protection } \\
\text { Agency (1996), } \\
\text { Hornsby and } \\
\text { others (1996) }\end{array}$ \\
\hline Propiconazole & $\begin{array}{l}\text { Alamo, Banner, Benit, Break, } \\
\text { Bumper, Desmel, Fidis, } \\
\text { Juno, Mantis, Maxx, Novel, } \\
\text { Practis, Orbit, Radar, } \\
\text { Restore, Spire, Taspa, Tilt, } \\
\text { Wocosin }\end{array}$ & Fungicide & $\begin{array}{r}60207- \\
90-1\end{array}$ & $\begin{array}{l}\text { Used on grasses grown } \\
\text { for seed, many } \\
\text { crops, conifors, } \\
\text { hardwoods, and } \\
\text { fruit trees. }\end{array}$ & $\begin{array}{l}\text { Wagner and } \\
\text { others (2006b), } \\
\text { Extension } \\
\text { Toxicology } \\
\text { Network (1997), } \\
\text { Hornsby and } \\
\text { others (1996) }\end{array}$ \\
\hline Propoxur & $\begin{array}{l}\text { Arprocarb, Bay 9010, Bayer } \\
\text { 39007, Baygon, Bifex, } \\
\text { Blattanex, Bolfo, Invisigard, } \\
\text { Mobay, PHC, Propogon, } \\
\text { Propyon, Rhoden, Sendra, } \\
\text { Sendran, Suncide, Tendex, } \\
\text { UNDEN, Undene }\end{array}$ & Insecticide & $114-26-1$ & $\begin{array}{l}\text { Used to control insects } \\
\text { in lawns, turf, } \\
\text { and buildings. }\end{array}$ & $\begin{array}{l}\text { Wagner and others } \\
\text { (2006b), Hornsby } \\
\text { and others } \\
\text { (1996), Extension } \\
\text { Toxicology } \\
\text { Network (1993e) }\end{array}$ \\
\hline Sulfometuron-methyl & $\begin{array}{l}\text { Oust Weed Killer and } \\
\text { DPX } 5648\end{array}$ & Herbicide & $\begin{array}{r}74222- \\
97-2\end{array}$ & $\begin{array}{l}\text { Used to control annual } \\
\text { and perennial } \\
\text { grasses and broad- } \\
\text { leaved weeds in non- } \\
\text { crop areas; also used } \\
\text { to control woody } \\
\text { tree species. }\end{array}$ & $\begin{array}{l}\text { Wagner and others } \\
\text { (2006b), Hornsby } \\
\text { and others } \\
\text { (1996), Extension } \\
\text { Toxicology } \\
\text { Network (1994) }\end{array}$ \\
\hline Tebuthiuron & $\begin{array}{l}\text { Spike, Brush Bullet, EL-103, } \\
\text { Graslan, Perflan, Herbec, } \\
\text { Herbic and Reclaim. }\end{array}$ & Herbicide & $\begin{array}{r}34014- \\
18-1\end{array}$ & $\begin{array}{l}\text { Used for the control of } \\
\text { weeds in non-crop } \\
\text { areas, rangelands, } \\
\text { rights-of-way and } \\
\text { industrial sites. }\end{array}$ & $\begin{array}{l}\text { Wagner and others } \\
\text { (2006b), Hornsby } \\
\text { and others } \\
\text { (1996), Extension } \\
\text { Toxicology } \\
\text { Network (1993f) }\end{array}$ \\
\hline
\end{tabular}

${ }^{1}$ This report contains CAS Registry Numbers $®$, which is a Registered Trademark of the American Chemical Society. CAS recommends the verification of the CASRNs through CAS Client ServicesSM. 


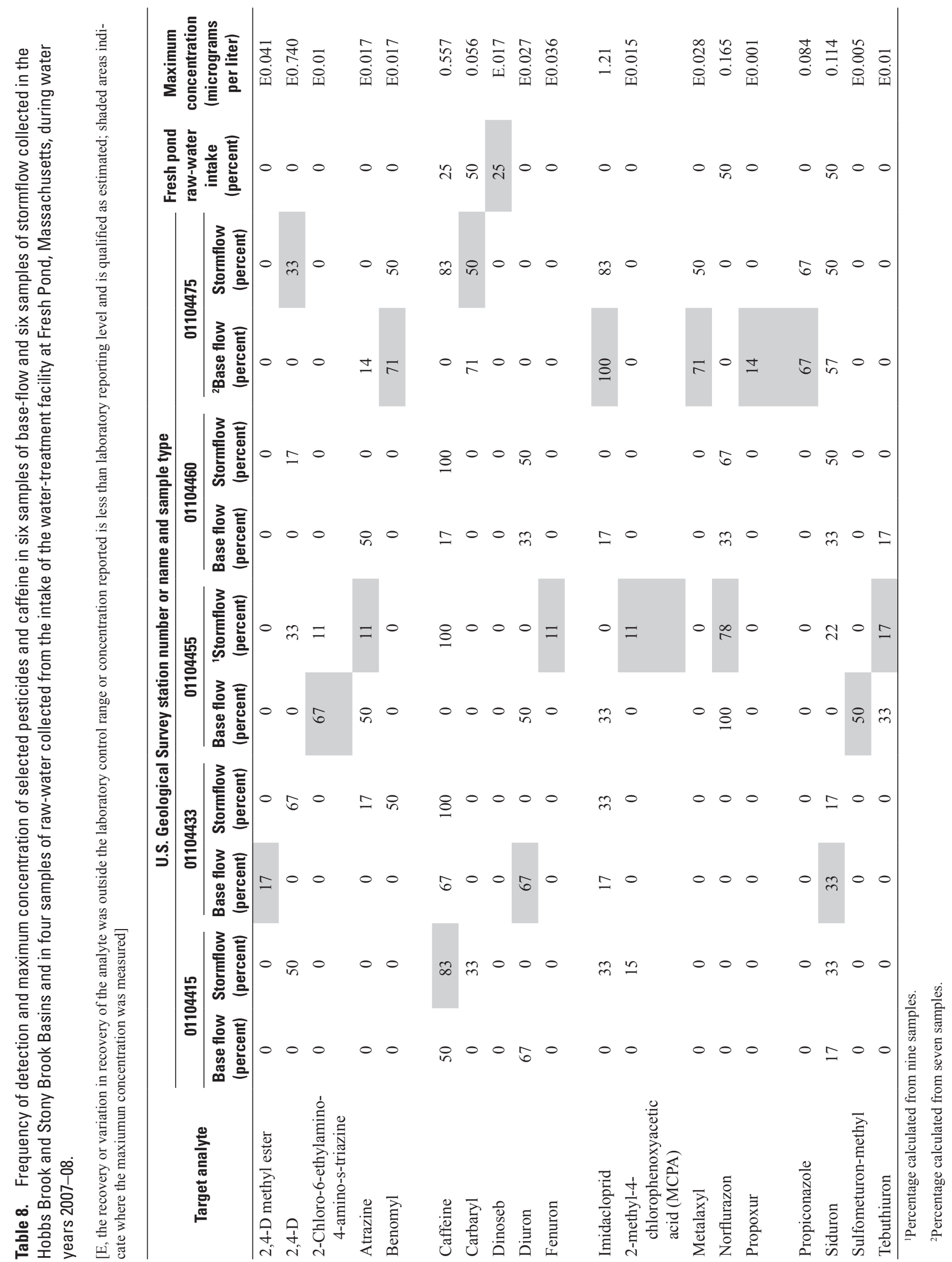


Eleven pesticides and caffeine were detected in water samples collected at the secondary sampling stations during water years 2007-08 (table 6). The detections for most pesticides at the secondary sampling stations were limited to samples collected during May, 2007. Atrazine and imidacloprid were the only pesticides detected in water samples from the secondary sampling station on Stony Brook (USGS station 01104390). Atrazine, as well as siduron and caffeine, also were detected in a water sample collected at USGS station 01104405. The pesticides 2-chloro-6ethylamino-4-amino-s-triazine, diuron, norflurazon, and sulfometuron-methyl were detected in water samples collected at USGS station 01104410. The pesticides 2,4-D, imidacloprid, norflurazon, and siduron, and caffeine were detected in water samples collected at USGS station 01104420. The pesticides diuron, norflurazon, and siduron, and caffeine were detected in water samples collected from Hobbs Brook below the Cambridge Reservoir (USGS station 01104430). With the exception of 2-chloro-6-ethylamino4-amino-s-triazine, norflurazon, and sulfometuron-methyl, all of the previous pesticides (2,4-D, atrazine, carbaryl, diuron, imidacloprid, metalazyl, and siduron) were measured in water samples collected from USGS station 01104453. Trace amounts of caffeine, carbaryl, dinoseb, norflurazon, and siduron were also detected in water from the Fresh Pond Reservoir (table 4; USGS station 422302071083802).

\section{Quality-Control Samples}

Trace amounts of calcium, sodium, and chloride were detected in field blanks (table 9, at end of report). The maximum concentration for these constituents measured in field blanks was one or more orders of magnitude less than the lowest concentration found in all environmental samples, and was within the precision of the laboratory methods (Fishman and Friedman, 1989). No other constituents were detected in either blank.

Field and laboratory concurrent replicate sets were analyzed by comparing the relative percent differences (RPDs) of the results for each pair of samples where the same analyte was detected in both samples. The maximum RPD for measurements of turbidity for replicate sets of water samples was less than about 62 percent, or 3.0 nephelometric turbidity ratio units (NTRUs). Measurements of $\mathrm{pH}$ for replicate sets were within $0.1 \mathrm{pH}$ unit of each other. The maximum RPD for both field and laboratory measurements of specific conductance was less than about 3 percent. The RPDs for calcium, sodium, chloride, sulfate, total nitrogen, and total phosphorus were also precise and varied by no more than about 6 percent, except the RPD for total phosphorus in a single replicate set, which was about 29 percent. Large RPDs for total phosphorus between replicate sets of water samples resulted from small differences in samples with low-level concentrations $(<0.01 \mathrm{mg} / \mathrm{L})$. The median absolute RPD for total phosphorus was about 5 percent.
Replicate data are not available for many pesticides because they were not detected in the environmental samples. Only 2-Chloro-6-ethylamino-4-amino-s-triazine, atrazine, benomyl, caffeine, carbaryl, diuron, imidacloprid, metalaxyl, norflurazon, propiconazole, siduron, sulfometuron, and tebuthiuron were measured in one or more of the replicate samples. The RPDs for these compounds were less than about 13 percent, except for atrazine (67 percent), diuron (4-40 percent), and siduron ( $0-29$ percent). Concentrations of diuron and siduron were measured in five of the nine replicate samples and were the most frequently detected pesticides.

Laboratory-preparation spiked samples provide a measure of method performance because they are processed and analyzed in the same manner as environmental samples. Laboratory-preparation spiked samples are prepared by adding known concentrations of target analytes to blank water. Field spike recoveries for organic compounds are compared to laboratory-preparation spike recoveries in table 10. During water year 2007, field spike recoveries for 27 out of 59 constituents measured in a water sample collected at USGS station 01104455 , and 11 out of 59 constituents measured in a water sample collected at USGS station 01104460 were outside of the lower and upper 99 percent confidence interval for analyte recoveries in laboratory-preparation spikes. The median RPD between the field spike and replicate field spike sample for USGS stations 01104455 and 01104460 was 12 and 3 percent, respectively. These data indicate that the recoveries of the spiked concentrations in the water samples, although poor for many constituents, were relatively precise. For USGS stations 01104475 and 422302071083802 during water year 2008, aldicarb sulfone was the only constituent for which field spike recoveries were outside of the lower and upper 99 percent confidence interval for analyte recoveries in laboratory-preparation spikes.

\section{Meteorological Data}

Monthly precipitation totals for the Cambridge drinking-water source area ranged from 0.69 in. to more than 9 in. during water years 2007-08 (table 4). The COVs for monthly precipitation totals for water year 2007 were similar-55 and 54 percent - for USGS station 01104430 at Cambridge Reservoir and 01104480 at Stony Brook Reservoir, respectively. The COVs for monthly precipitation totals for USGS station 422302071083801 at Fresh Pond Reservoir was about 62 percent for water year 2007 and the annual precipitation total was about 8 in. lower than the totals for the gages at the Cambridge and Stony Brook Reservoirs. For water year 2008, the COVs for monthly precipitation totals for all three stations were similar, ranging from about 45 to 49 percent. However, the annual precipitation total for the Fresh Pond Reservoir was about 8 in. lower than the total precipitation measured at the Cambridge and Stony Brook Reservoirs. 


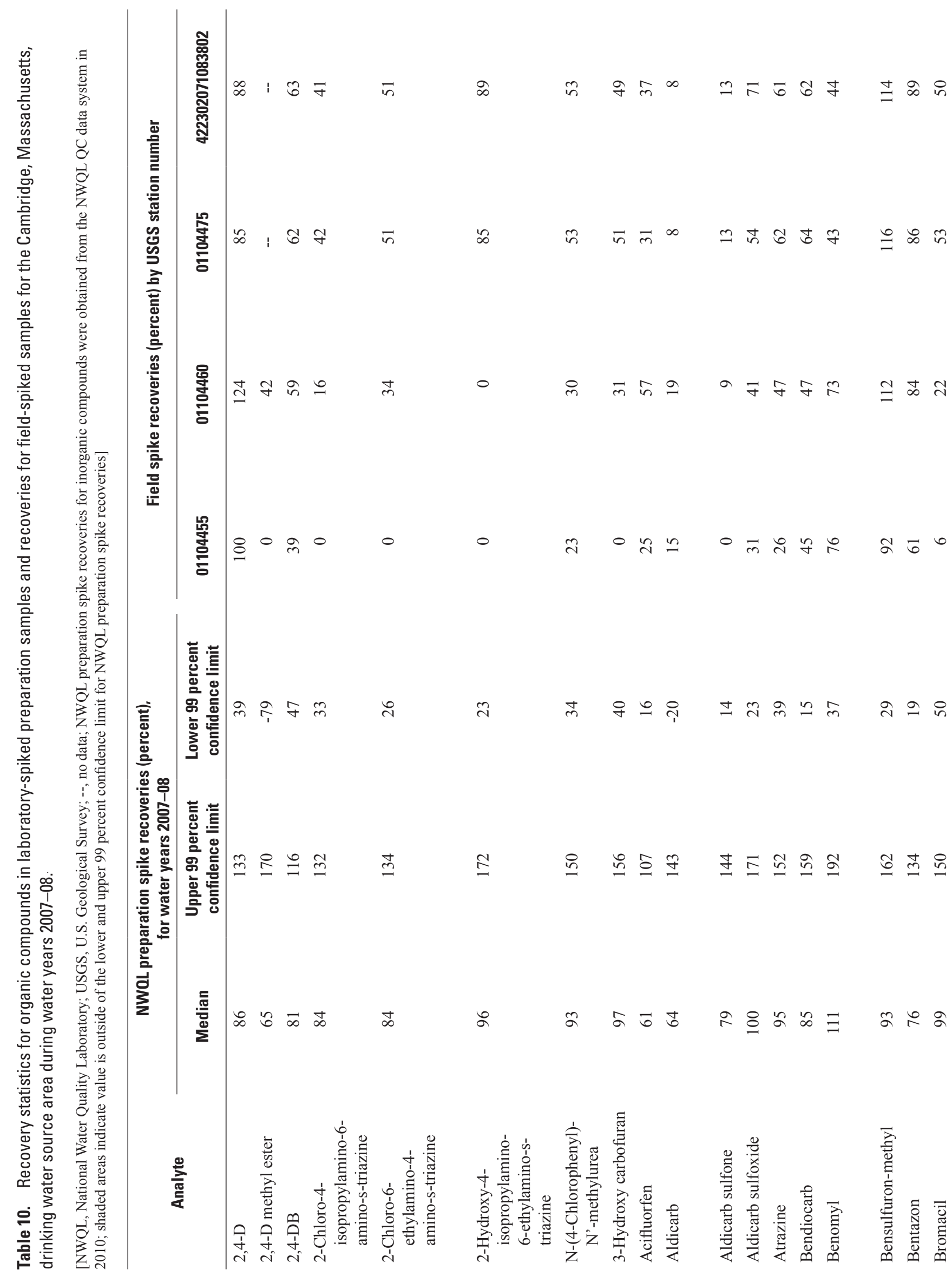




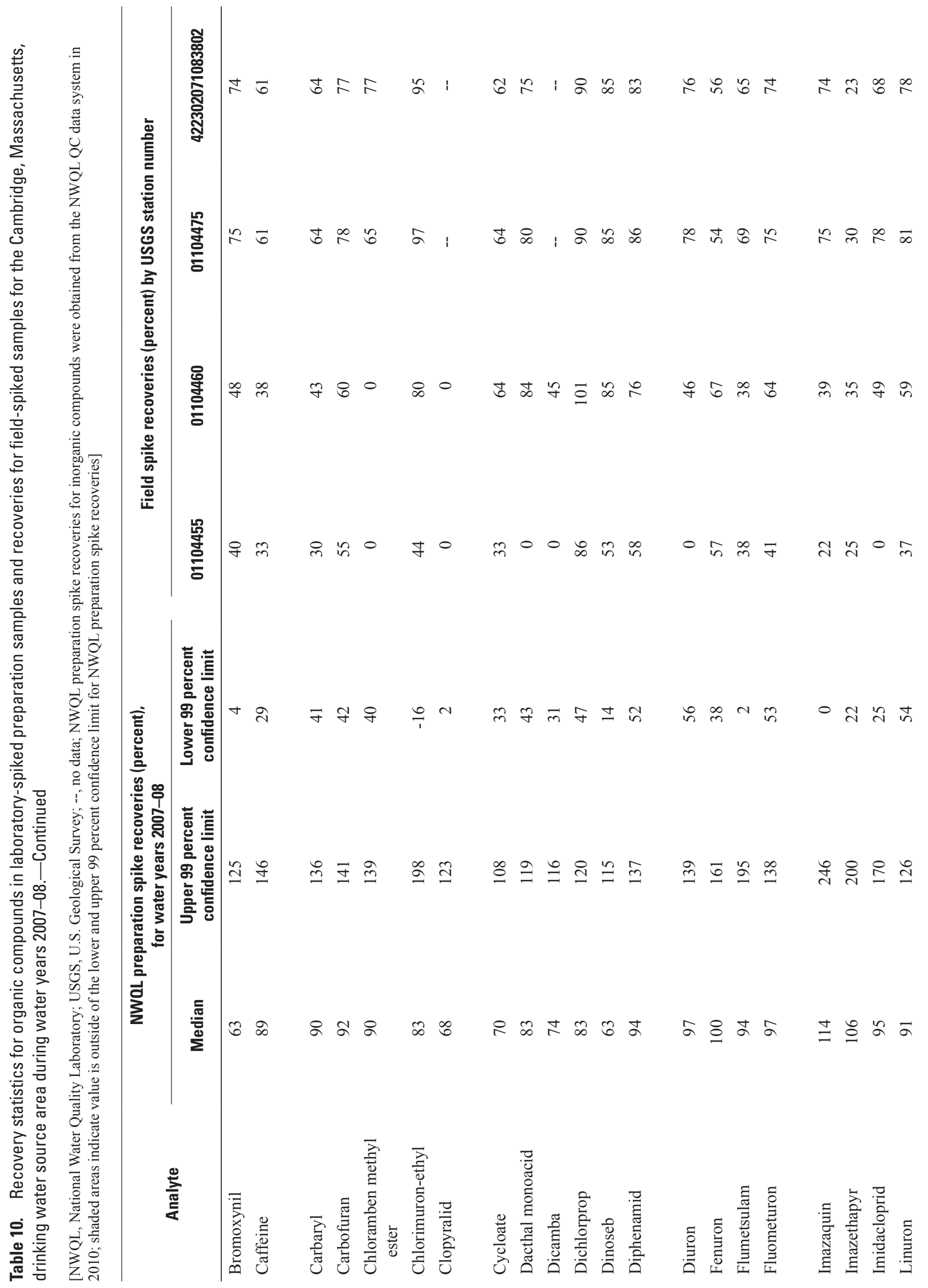




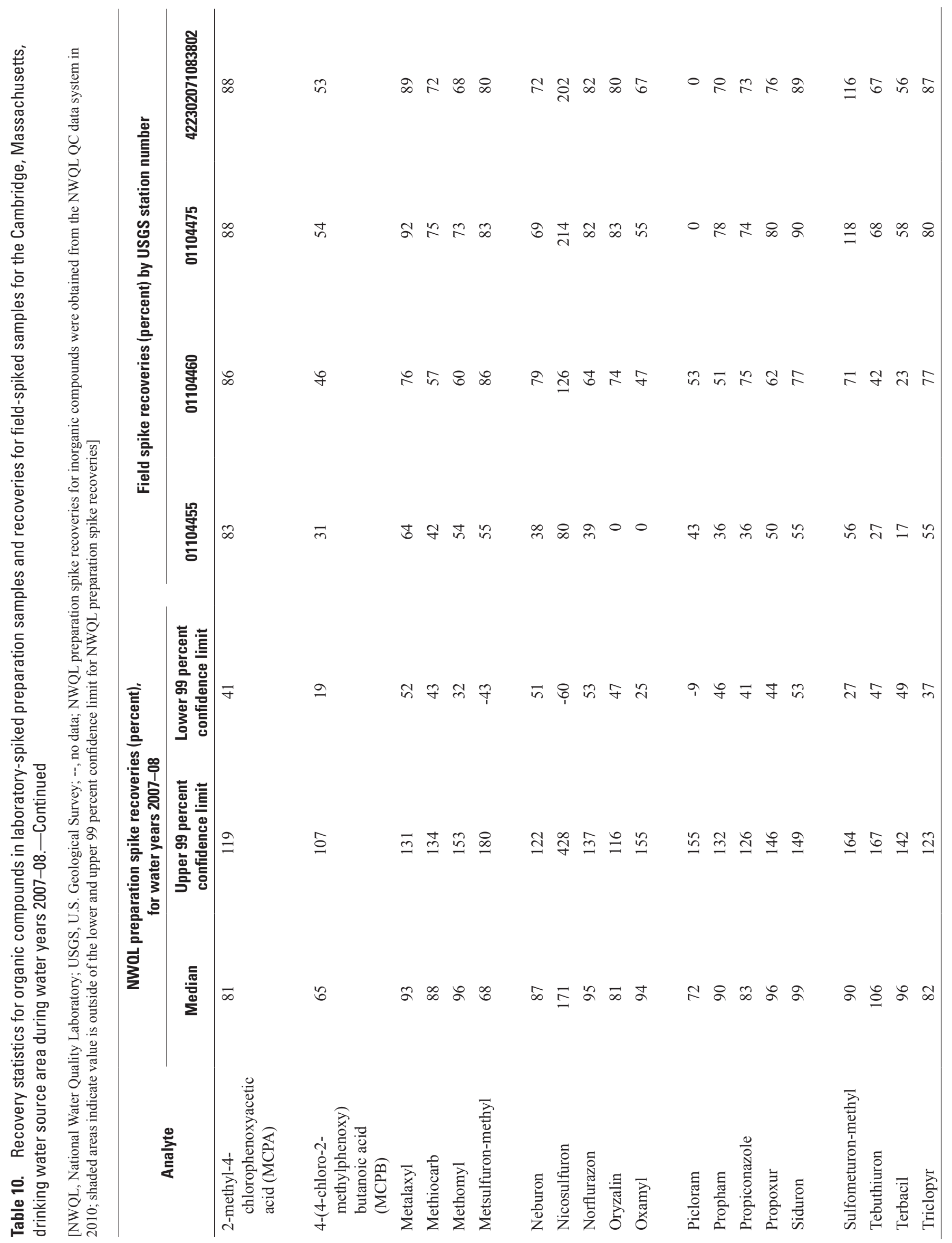


In general, variability between monthly precipitation totals for all stations is attributed to differences in storm tracks, storm-intensity patterns, and storm wind intensity. Additionally, the variability between monthly precipitation totals during the winter months is compounded by the change from rainfall to snowfall because snow is less dense than rain and, therefore, is affected more strongly by wind. Totals are generally lower for the precipitation gage at USGS station 422302071083801 because it does not contain a wind screen and is more susceptible to wind bias than the other gages (table 4).

The annual precipitation total recorded at USGS station 01104430 during water year 2007 (46.89 in.) was about 5 to 21 percent lower than recorded totals for the previous four water years (Smith, 2005 and 2007; Socolow and others, 2003,
2004). Monthly precipitation totals for this station during water year 2007 were generally within the minimum and maximum precipitation totals for water years 2002-06, except for the months of December, August, and September, which were lower (fig. 12). The annual precipitation total of 61.78 in. during water year 2008 was about 5 to 32 percent higher than recorded totals for water years 2002-07 (Smith, 2005, 2007; Socolow and others, 2003, 2004). Monthly precipitation totals during water year 2008 were generally equal to or greater than the median monthly precipitation total for water years 2002-07, except for the months of October, November, May, and August, which were lower than the median monthly value (fig. 12). For the months of February, July, and September, the monthly precipitation totals were substantially greater than prior maximum precipitation totals.

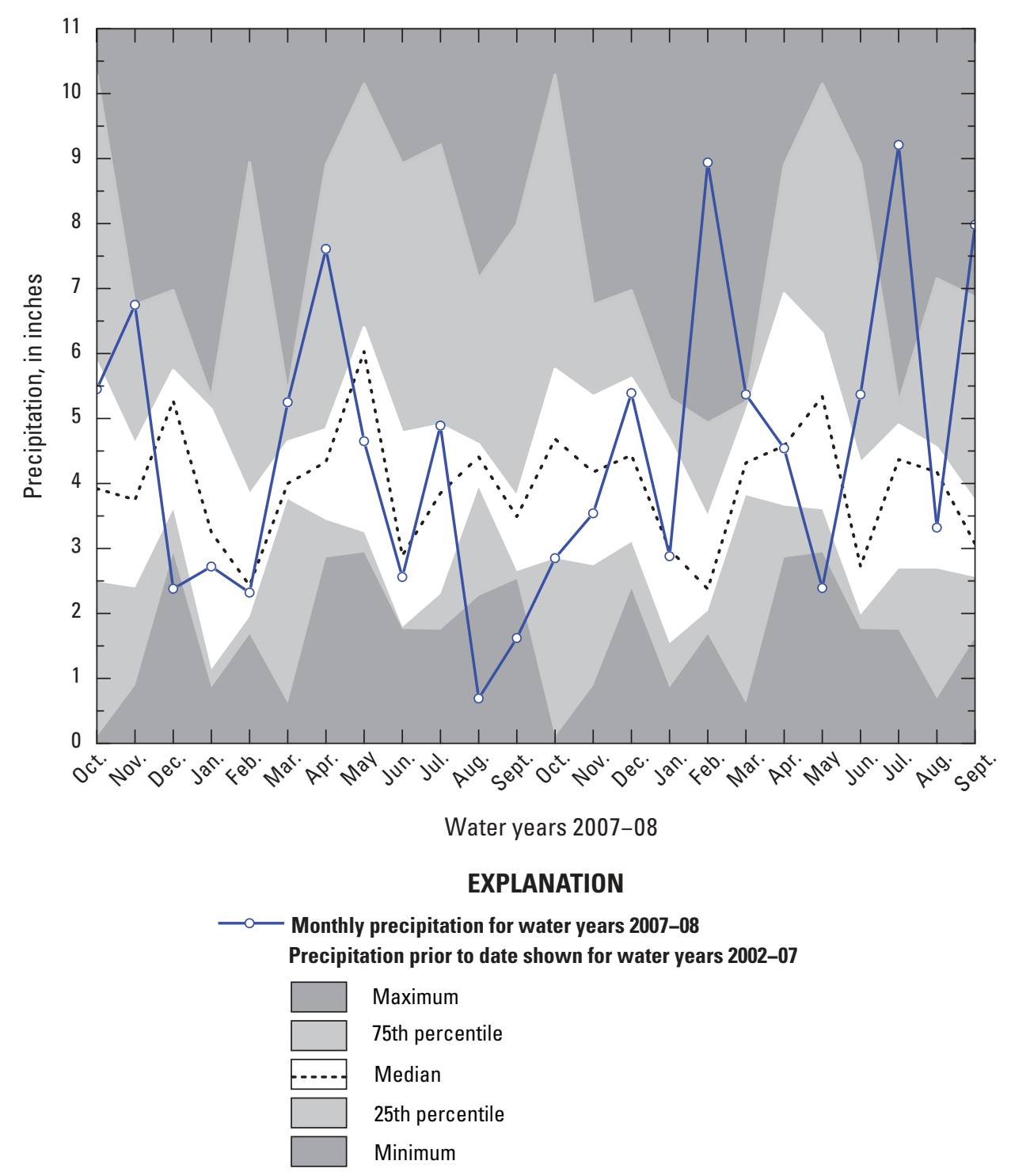

Figure 12. Monthly precipitation for water years 2007-08 for U.S. Geological Survey station 01104430, Hobbs Brook below Cambridge Reservoir, near Kendal Green, Massachusetts. 
Mean monthly air-temperature values were similar between the Cambridge and Stony Brook Reservoirs, differing by no more than about $0.5^{\circ} \mathrm{C}$ (U.S. Geological Survey, 2009). Mean monthly air-temperature values varied most in January and September (U.S. Geological Survey, 2009). During water years $2007-08$, mean monthly air-temperature values for USGS station 01104430 were within $3^{\circ} \mathrm{C}$ of the median values for water years 2002-06 and 2002-07, except for the December 2007 , which was about $4^{\circ} \mathrm{C}$ greater than the median for water years 2002-06, and for February 2008, which was $-3.1^{\circ} \mathrm{C}$ less than the median value for water years $2002-07$ (Smith, 2005, 2007; Socolow and others, 2002, 2003; U.S. Geological Survey, 2009).

\section{References Cited}

American Public Health Association, 1998, Standard methods for the examination of water and wastewater (20th ed.): Washington, D.C., American Public Health Association, American Water Works Association, and Water Environment Federation, p. 3-37-3-43.

Bedient, P.B., and Huber, W.C., 2002, Hydrology and floodplain analysis ( $3 \mathrm{~d}$ ed.): New Jersey, Prentice Hall, $692 \mathrm{p}$.

Buchanan, T.J., and Somers, W.P., 1968, Stage measurements at gaging stations: U.S. Geological Survey Techniques of Water-Resources Investigations, book 3, chap. A7, 28 p.

Buchanan, T.J., and Somers, W.P., 1969, Discharge measurements at gaging stations: U.S. Geological Survey Techniques of Water-Resources Investigations, book 3, chap. A8, 65 p.

Carter, R.W., and Davidian, Jacob, 1968, General procedure for gaging streams: U.S. Geological Survey Techniques of Water-Resources Investigations, book 3, chap. A6, 13 p.

Commonwealth of Massachusetts, Executive Office of Energy and Environmental Affairs, Department of Environmental Protection, Office of Research and Standards, 2009, Standards and guidelines for contaminants in Massachusetts drinking waters: accessed February 16, 2010, at http:/www. mass.gov/dep/water/dwstand.pdf.

Extension Toxicology Network, 1993a, Pesticide information profile for Dinoseb: accessed February 08, 2010, at http://pmep.cce.cornell.edu/profiles/extoxnet/dienochlorglyphosate/dinoseb-ext.html.

Extension Toxicology Network, 1993b, Pesticide information profile for diuron: accessed April 05, 2006, at http://pmep. cce.cornell.edu/profiles/extoxnet/dienochlor-glyphosate/ diuron-ext.html.
Extension Toxicology Network, 1993c, Pesticide information profile for MCPA: accessed April 05, 2006, at http:// pmep.cce.cornell.edu/profiles/extoxnet/haloxyfopmethylparathion/mcpa-ext.html.

Extension Toxicology Network, 1993d, Pesticide information profile for metalaxyl: accessed April 05, 2006, at http:// pmep.cce.cornell.edu/profiles/extoxnet/haloxyfopmethylparathion/metalaxyl-ext.html.

Extension Toxicology Network, 1993e, Pesticide information profile for propoxur: accessed April 05, 2006, at http:// pmep.cce.cornell.edu/profiles/extoxnet/metiram-propoxur/ propoxur-ext.html.

Extension Toxicology Network, 1993f, Pesticide information profile for Tebuthiuron: accessed February 08, 2010, at http://pmep.cce.cornell.edu/profiles/extoxnet/pyrethrinsziram/tebuthiuron-ext.html.

Extension Toxicology Network, 1994, Pesticide information profile for Sulfometuron-methyl: accessed February 08, 2010, at http://pmep.cce.cornell.edu/profiles/extoxnet/ pyrethrins-ziram/sulfometuron-methyl-ext.html.

Extension Toxicology Network, 1996, Pesticide information profile for Benomyl: accessed February 08, 2010, at http:// extoxnet.orst.edu/pips/benomyl.htm.

Extension Toxicology Network, 1997, Pesticide information profile for propiconazole: accessed April 05, 2006, at http:// pmep.cce.cornell.edu/profiles/extoxnet/metiram-propoxur/ propiconazole-ext.html.

Extension Toxicology Network, 2005, Pesticide information profile for imidacloprid: accessed April 05, 2006, at http://pmep.cce.cornell.edu/profiles/extoxnet/haloxyfopmethylparathion/imidacloprid-ext.html.

Fishman, M.J., ed., 1993, Methods of analysis by the U.S. Geological Survey National Water Quality LaboratoryDetermination of inorganic and organic constituents in water and fluvial sediments: U.S. Geological Survey OpenFile Report 93-125, 217 p.

Fishman, M.J., and Friedman, L.C., 1989, Methods for determination of inorganic substances in water and fluvial sediments: U.S. Geological Survey Techniques of WaterResources Investigations, book 5, chap. A1, 545 p.

Furlong, E.T., Anderson, B.D., Werner, S.L., Soliven, P.P., Coffey, L.J., and Burkhardt, M.R., 2001, Methods of analysis by the U.S. Geological Survey National Water Quality Laboratory-Determination of pesticides in water by graphitized carbon-based solid-phase extraction and high-performance liquid chromatography/mass spectrometry: U.S. Geological Survey Water-Resources Investigations Report 01-4134, $73 \mathrm{p}$. 
Garbarino, J.R., Kanagy, L.K., and Cree, M.E., 2006, Determination of elements in natural-water, biota, sediment and soil samples using collision/reaction cell inductively coupled plasma-mass spectrometry: U.S. Geological Survey Techniques and Methods, book 5, sec. B, chap. 1, $88 \mathrm{p}$.

Hornsby, A.G., Wauchope, R.D., and Herner, A.E., 1996, Pesticide properties in the environment: New York, Springer-Verlag, $227 \mathrm{p}$.

Kennedy, E.J., 1983, Computation of continuous records of streamflow: U.S. Geological Survey Techniques of WaterResources Investigations, book 3, chap. A13, 52 p.

Kennedy, E.J., 1984, Discharge ratings at gaging stations: U.S. Geological Survey Techniques of Water-Resources Investigations, book 3 , chap. A10, 59 p.

Oberg, K.A., Morlock, S.E., and Caldwell, W.S., 2005, Quality-assurance plan for discharge measurements using acoustic Doppler current profilers: U.S. Geological Survey Scientific Investigations Report 2005-5183, 35 p.

Patterson, Glenn, 1997, The U.S. Geological Survey drinking water initiative: U.S. Geological Survey Fact Sheet 047-97, 2 p.

Patton, C.J., and Kryskalla, J.R., 2003, Methods of analysis by the U.S. Geological Survey National Water Quality Laboratory-Evaluation of alkaline persulfate digestion as an alternative to kjeldahl digestion for determination of total and dissolved nitrogen and phosphorus in water: U.S. Geological Survey Water-Resources Investigations Report 03-4174, $33 \mathrm{p}$.

Rantz, S.E., and others, 1982, Measurement and computation of streamflow-Volume 1. Measurement of stage and discharge: U.S. Geological Survey Water-Supply Paper $2175,284 \mathrm{p}$.

Seiler, R.L., Zaugg, S.D., Thomas, J.M., and Howcroft, D.L., 1999, Caffeine and pharmaceuticals as indicators of waste water contamination in wells: Ground Water, v. 37 no. 3, p. $405-410$.

Smith, K.P., 2005, Hydrologic, water-quality, bed-sediment, soil-chemistry, and statistical summaries of data for the Cambridge, Massachusetts, drinking-water source area, water year 2004: U.S. Geological Survey Open-File Report 2005-1383, $110 \mathrm{p}$.

Smith, K.P., 2007, Hydrologic, water-quality, and meteorological data for the Cambridge, Massachusetts, drinking-water source area, water year 2005: U.S. Geological Survey Open-File Report 2007-1049, 119 p.
Smith, K.P., 2008, Hydrologic, water-quality, and meteorological data for the Cambridge, Massachusetts, drinking-water source area, water year 2006: U.S. Geological Survey Open-File Report 2008-1175, 165 p.

Socolow, R.S., Comeau, L.Y., Zanca, J.L., and Ramsbey, L.R., 1999, Water-resources data for Massachusetts and Rhode Island, water year 1998: U.S. Geological Survey WaterData Report MA-RI-98-1, 438 p.

Socolow, R.S., Girouard, G.G., and Ramsbey, L.R., 2003, Water-resources data for Massachusetts and Rhode Island, water year 2002: U.S. Geological Survey Water-Data Report MA-RI-02-1, 339 p.

Socolow, R.S., Leighton, J.F., Whitley, J.F., and Ventetuolo, D.J., 2002, Water-resources data for Massachusetts and Rhode Island, water year 2001: U.S. Geological Survey Water-Data Report MA-RI-01-1, 307 p.

Socolow, R.S., Whitley, J.S., Murino, D., Jr., and Ramsbey, L.R., 2001, Water-resources data for Massachusetts and Rhode Island, water year 2000: U.S. Geological Survey Water-Data Report MA-RI-00-1, 459 p.

Socolow, R.S., Zanca, J.L., Driskell, T.R., and Ramsbey, L.R., 2004, Water-resources data for Massachusetts and Rhode Island, water year 2003: U.S. Geological Survey WaterData Report MA-RI-03-1, 368 p.

Socolow, R.S., Zanca, J.L., Murino, D., Jr., and Ramsbey, L.R., 2000, Water-resources data for Massachusetts and Rhode Island, water year 1999: U.S. Geological Survey Water-Data Report MA-RI-99-1, 401 p.

U.S. Environmental Protection Agency, 1994, RED FACTS Metalaxyl: accessed April 05, 2006, at http://www.epa.gov/ oppsrrd1/REDs/factsheets/0081fact.pdf.

U.S. Environmental Protection Agency, 1996, RED FACTS Norflurazon: accessed April 05, 2006, at http://www.epa. gov/oppsrrd1/REDs/factsheets/0229fact.pdf.

U.S. Environmental Protection Agency, 2001, Benomyl RED Facts: Benomyl fact sheet, EPA-738-F-02-001.

U.S. Environmental Protection Agency, 2004a, Carbaryl IRED facts: accessed April 05, 2006, at http://www.epa.gov/ oppsrrd1/REDs/factsheets/carbaryl_factsheet.pdf.

U.S. Environmental Protection Agency, 2004b, RED FACTS MCPA: accessed April 05, 2006, at http://www.epa.gov/ oppsrrd1/REDs/factsheets/mcpa_red_fs.pdf.

U.S. Environmental Protection Agency, 2006, Consumer fact sheet on 2,4-D: accessed April 05, 2006, at http://www.epa. gov/safewater/contaminants/dw_contamfs/24-d.html. 
U.S. Environmental Protection Agency, 2007, List of national secondary drinking water regulations: accessed September 24, 2007, at http://www.epa.gov/safewater/contaminants/ index.html\#sec.

U.S. Geological Survey, 2009, Water-resources data for the United States, Water Year 2008: U.S. Geological Survey Water-Data Report WDR-US-2007, accessed April 1, 2008, and January 21, 2010, at http://wdr.water.usgs.gov/.

Wagner, R.J., Boulger, R.W., Jr., Oblinger, C.J., and Smith, B.A., 2006a, Guidelines and standard procedures for continuous water-quality monitors-Station operation, record computation, and data reporting: U.S. Geological Survey Techniques and Methods 1-D3, 51 p. +8 attachments, accessed April 10, 2006, at http://pubs.water. usgs.gov/tm1d3.
Wagner, R.J., Frans, L.M., and Huffman, R.L., 2006b, Occurrence, distribution, and transport of pesticides in agricultural irrigation return flow from four drainage basins in the Columbia Basin Project, Washington, 2002-2004, and comparison with historical data: U.S. Geological Survey Scientific Investigations Report 2006-5005, 54 p.

Waldron, M.C., and Bent, G.C., 2001, Factors affecting reservoir and stream-water quality in the Cambridge, Massachusetts, drinking-water source area and implications for source-water protection: U.S. Geological Survey WaterResources Investigations Report 00-4262, 89 p.

Wilde, F.D., Radtke, D.B., Gibs, Jacob, and Iwatsubo, R.T., eds., September 1999, Collection of water samples: U.S. Geological Survey Techniques of Water-Resources Investigations, book 9, chap. A4, accessed November 2, 2006, at http://pubs.water.usgs.gov/twri9A4/. 


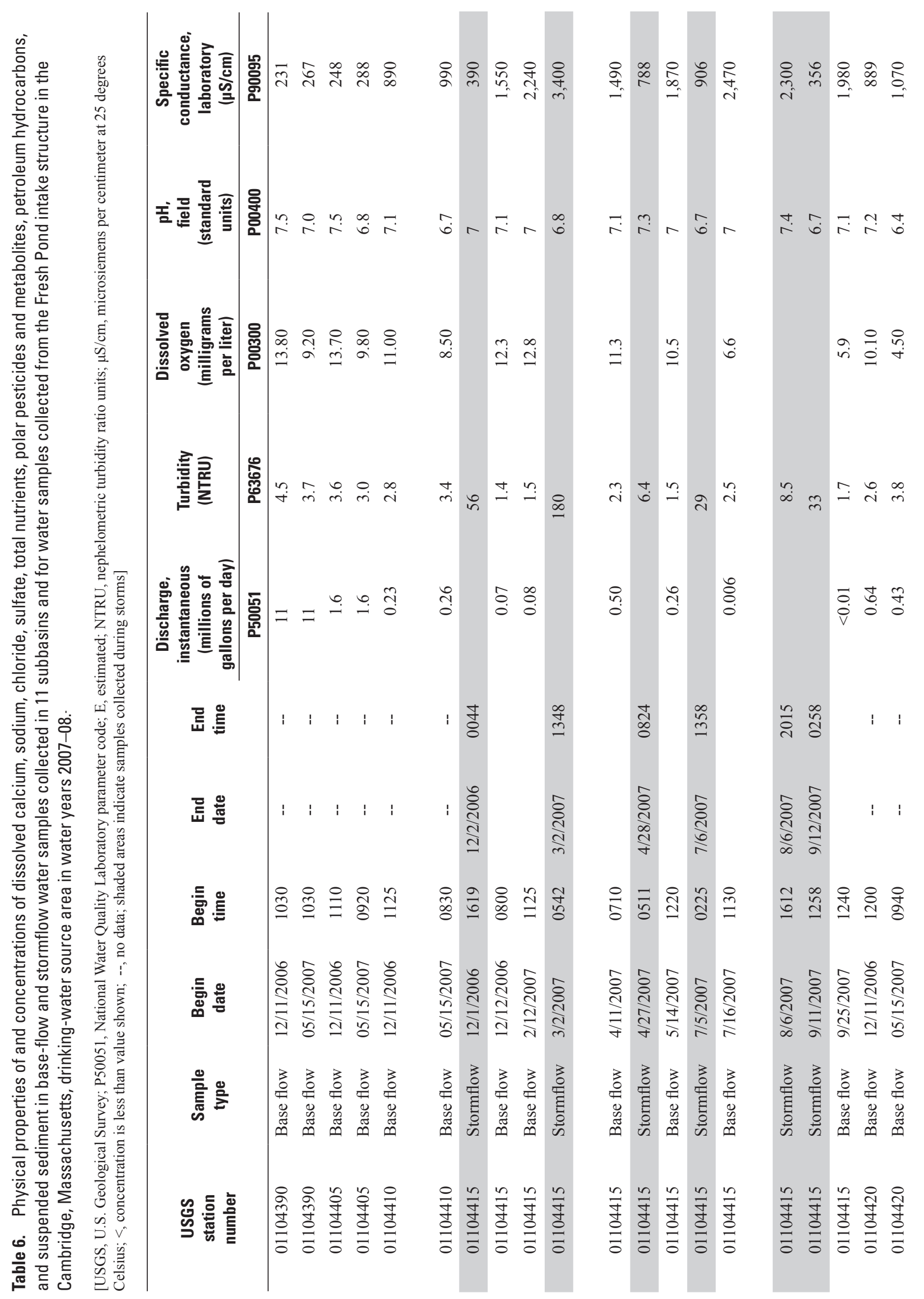




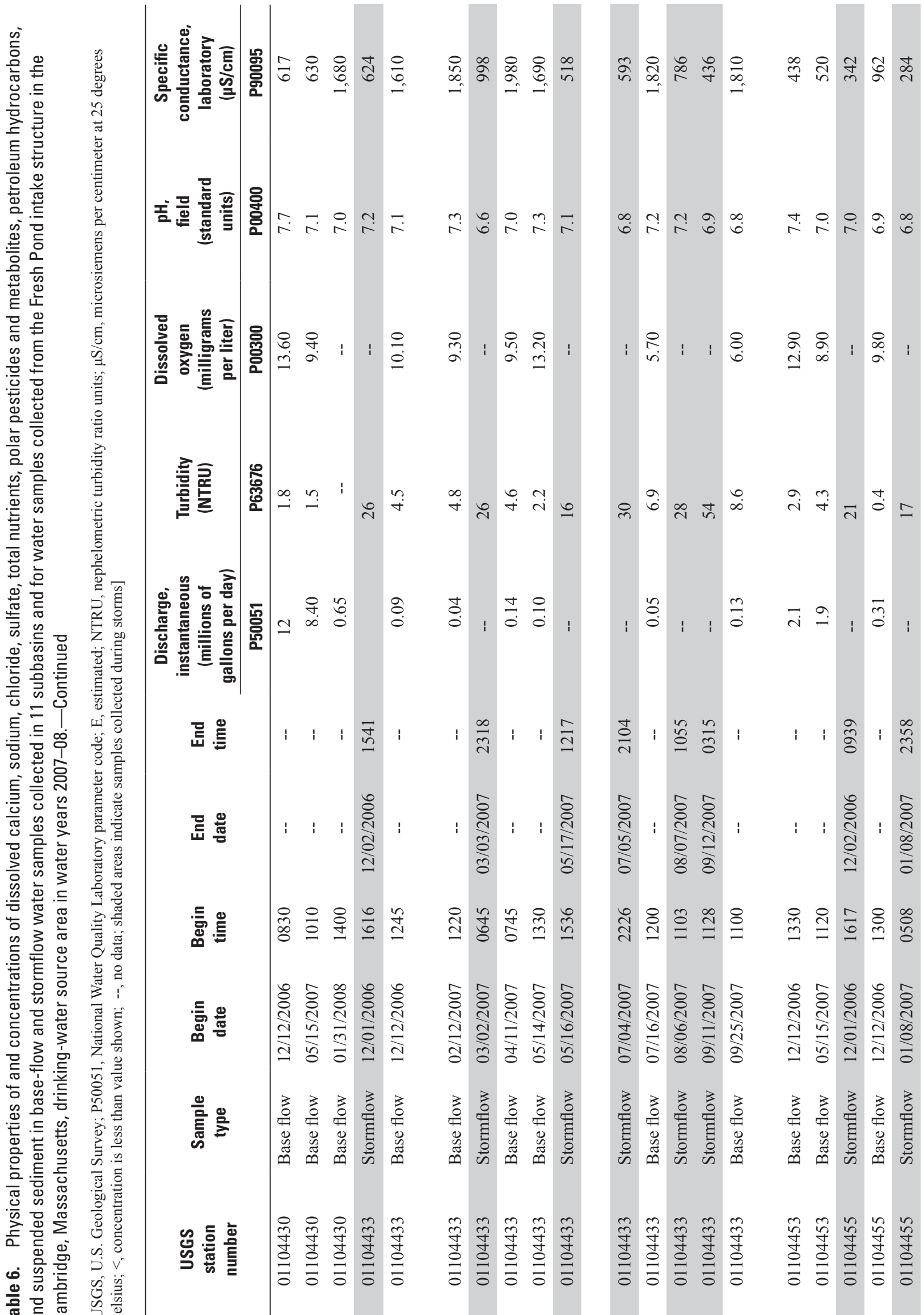




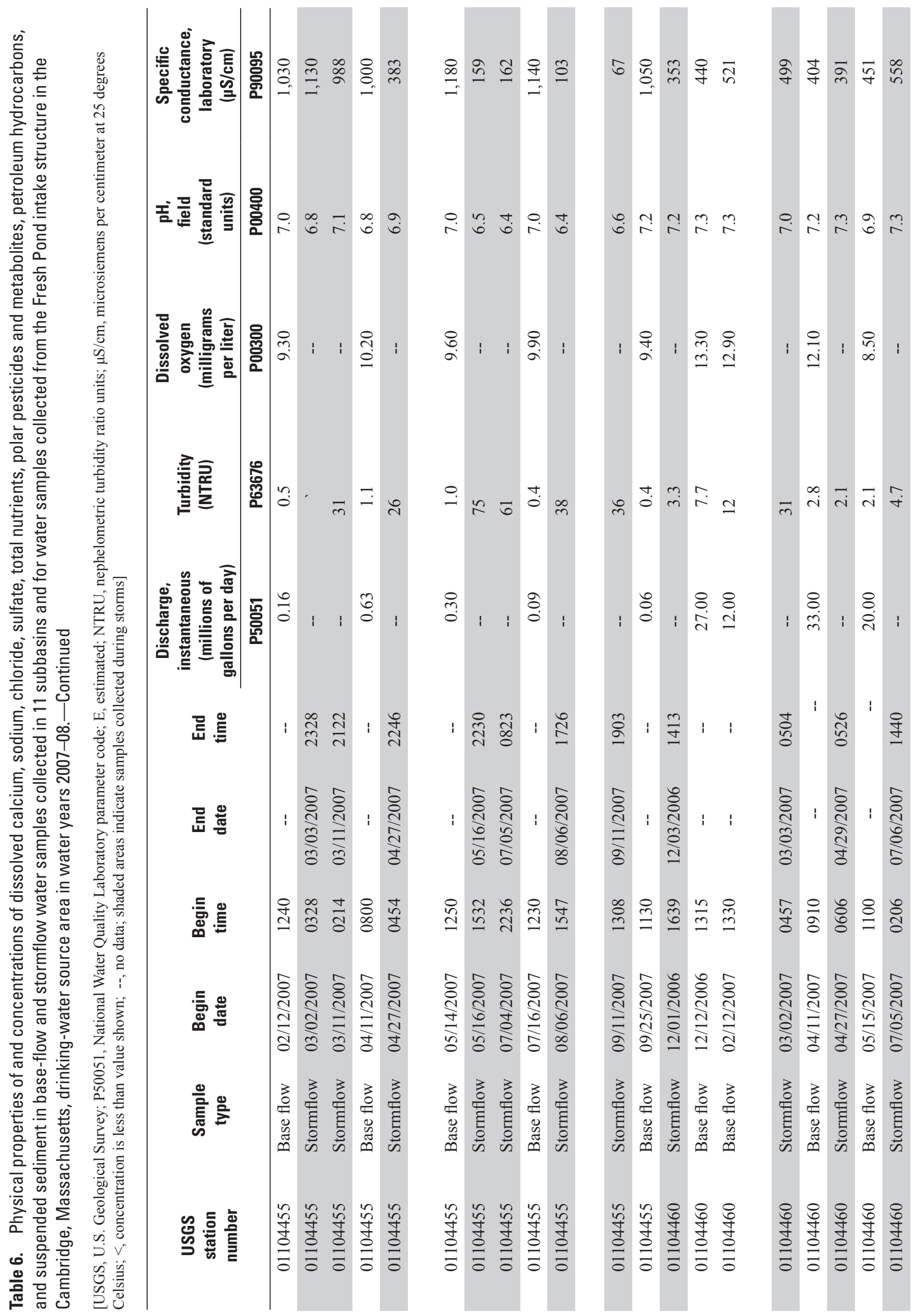




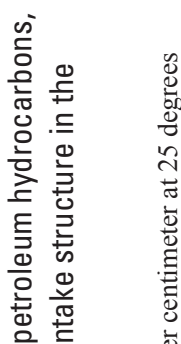
|

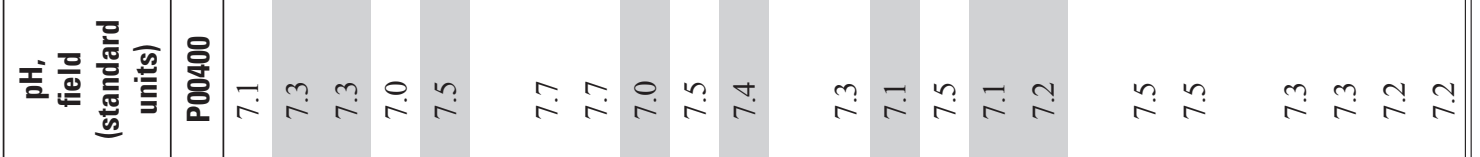

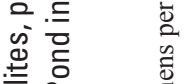

त्ञ

히 님

응 일

ब

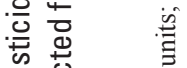

总

층

穿

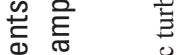

禀

范

운

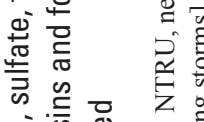

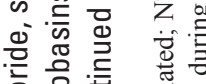

음 के 등

Eं।

言 잉 웡

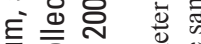

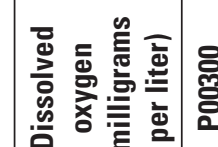

융

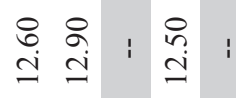

요

ㅇำ

\& ఖ

얼 히

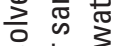

क्षे

噧

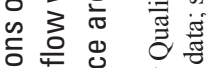

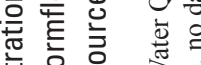

든 क्ष

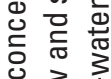

0 3

플

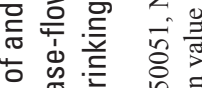

\&

鸟

œ

要

흐릉 둥

然

焉

¿

वे के क्ठ

은믐 $\triangleright$

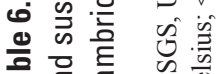

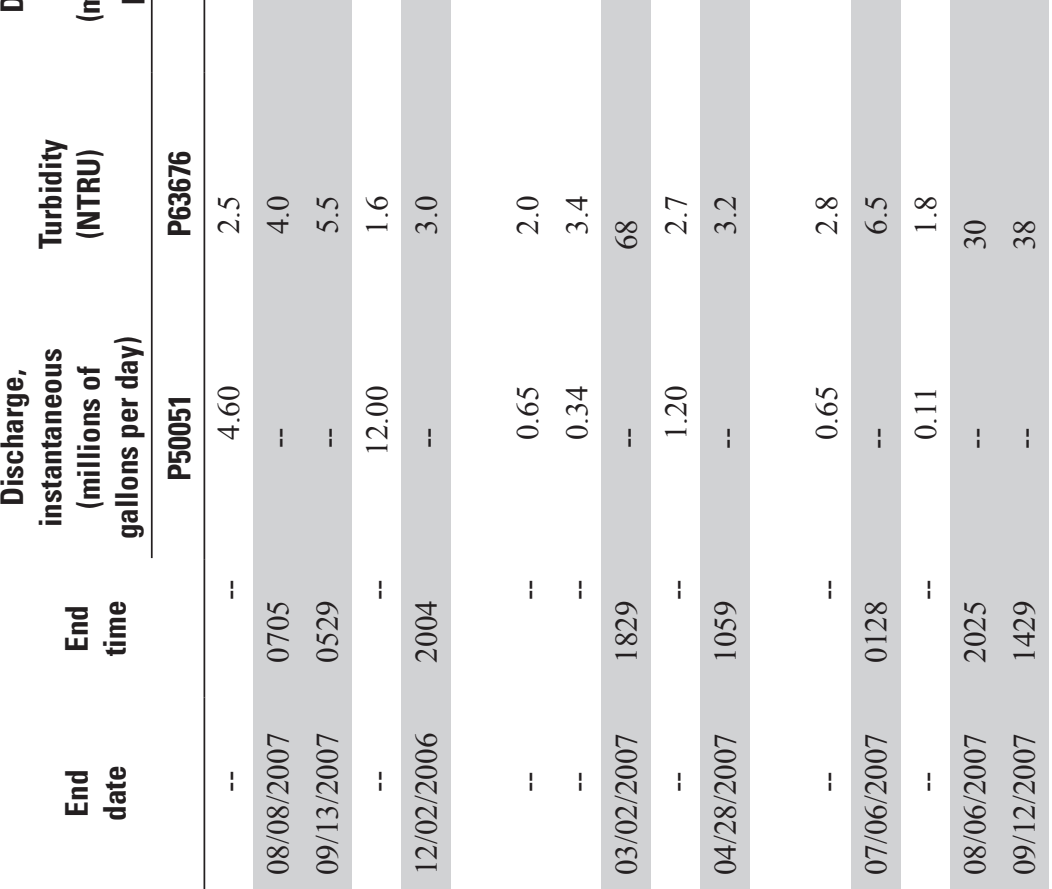

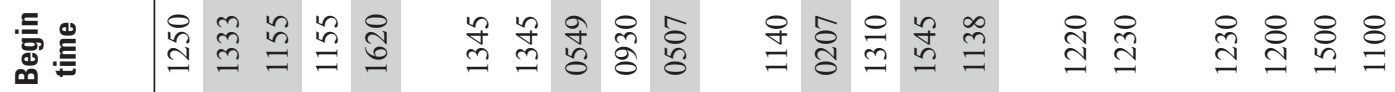

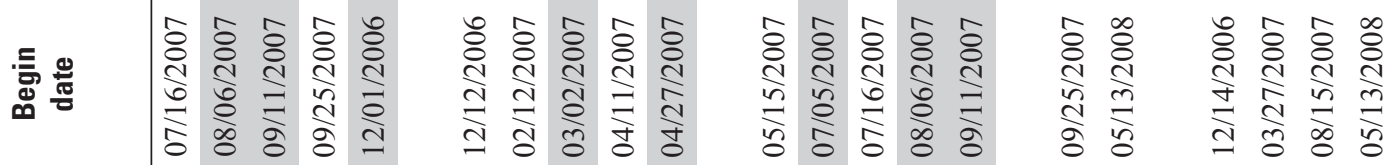

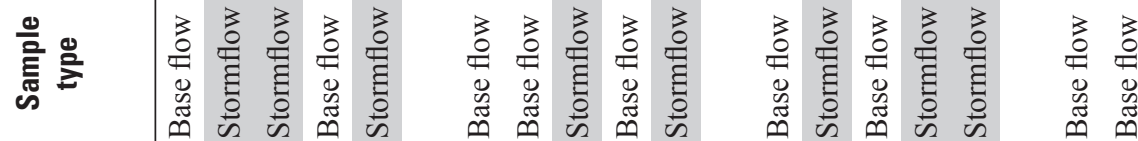

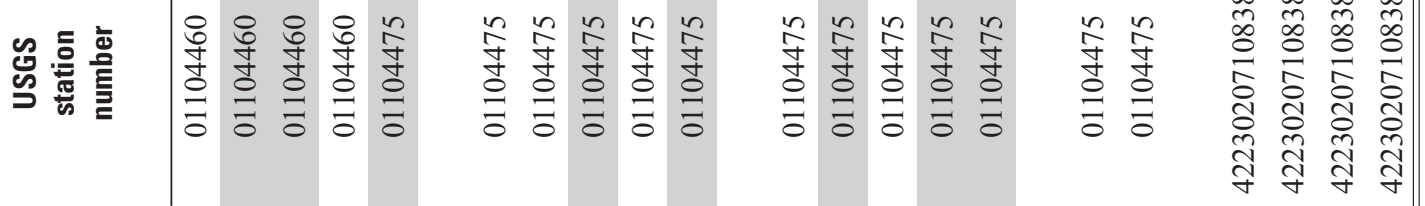




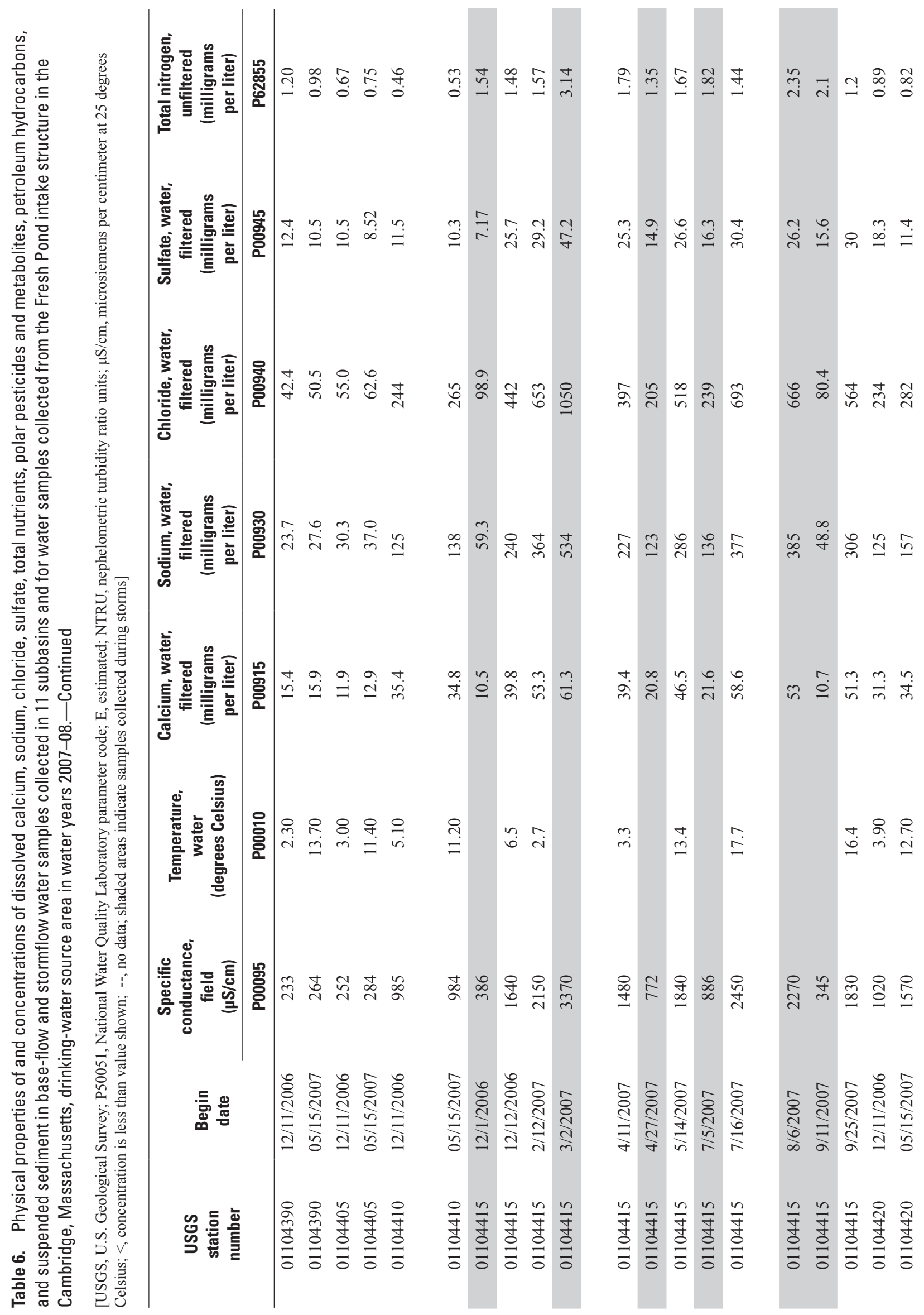




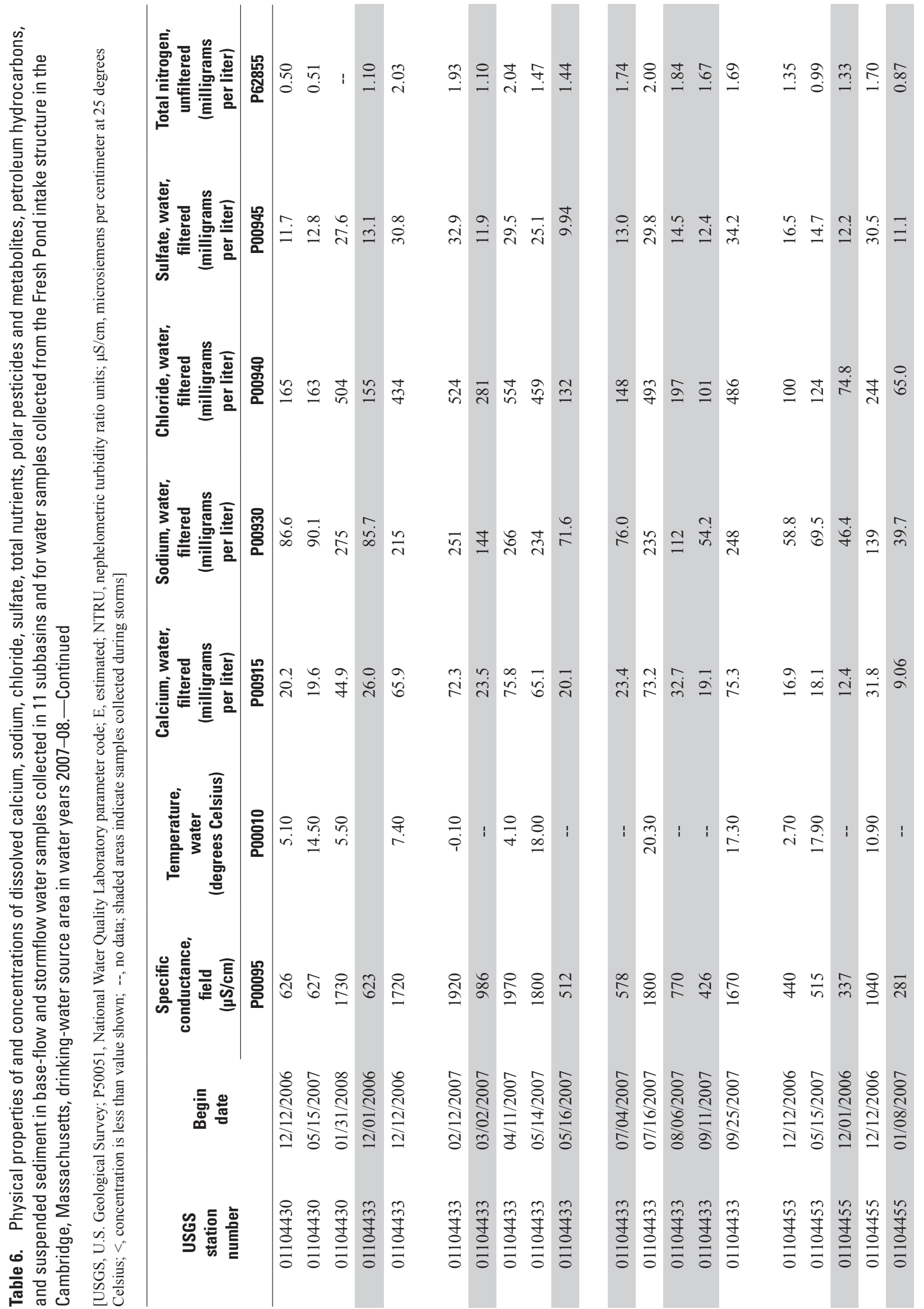




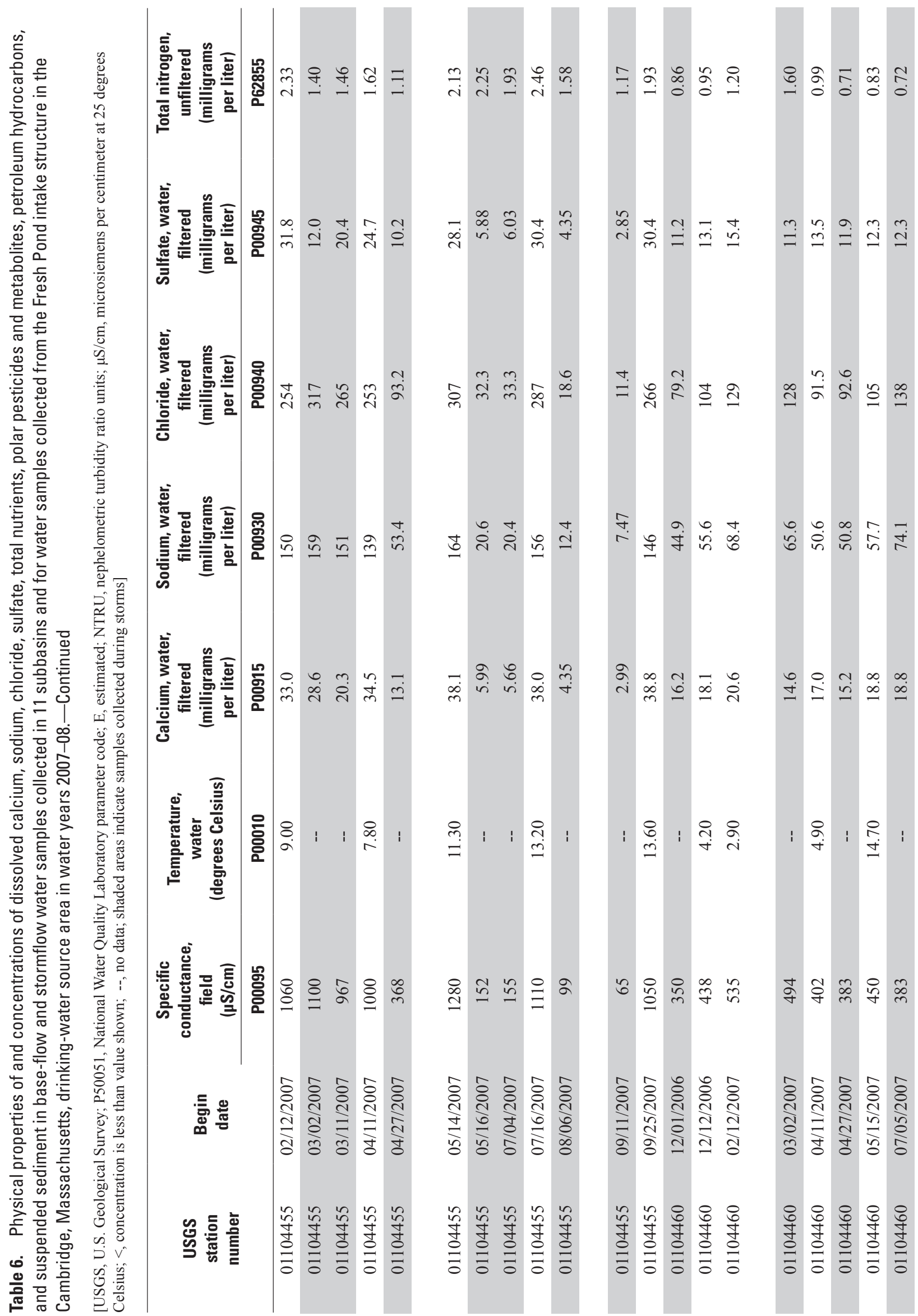




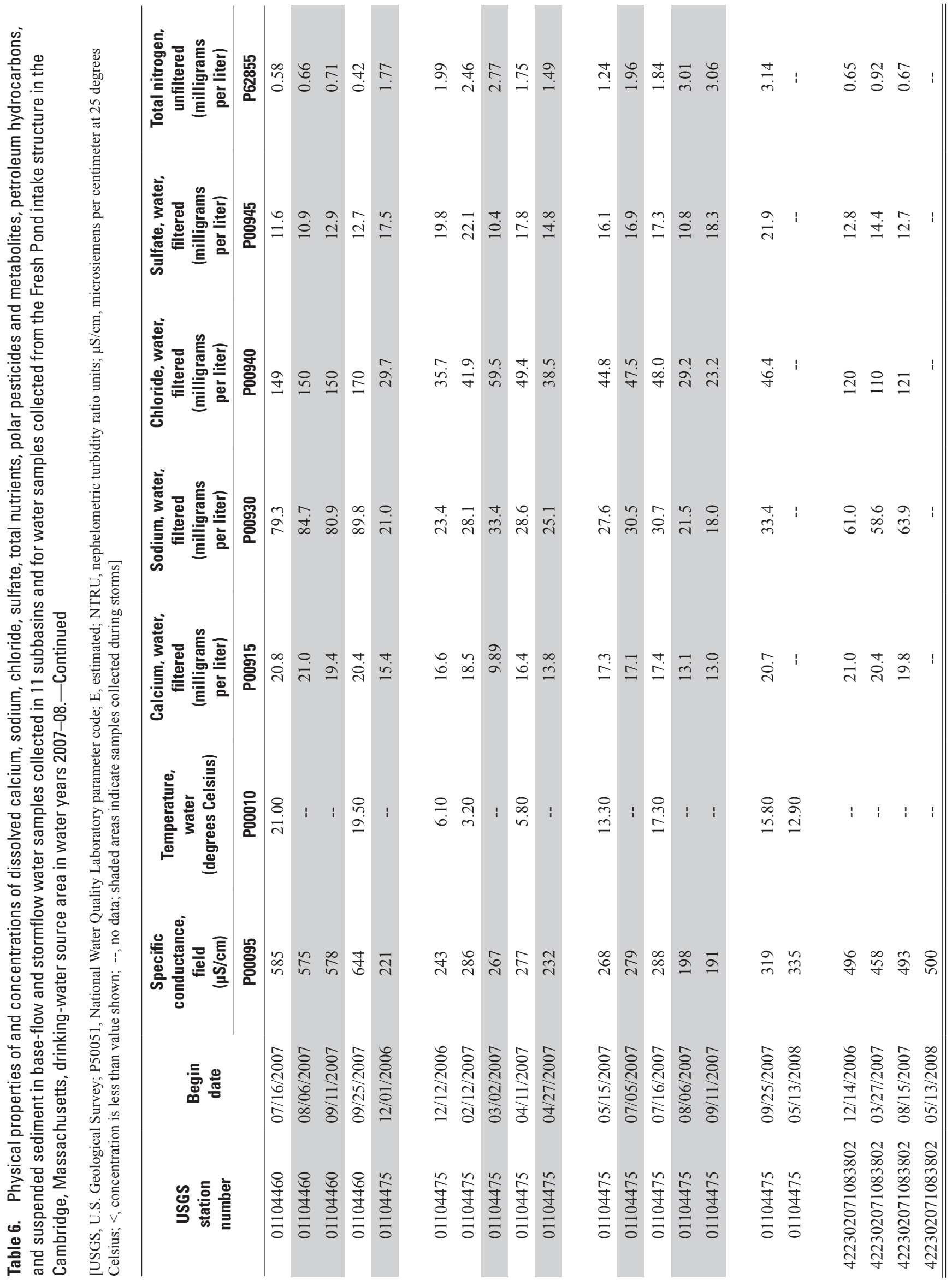




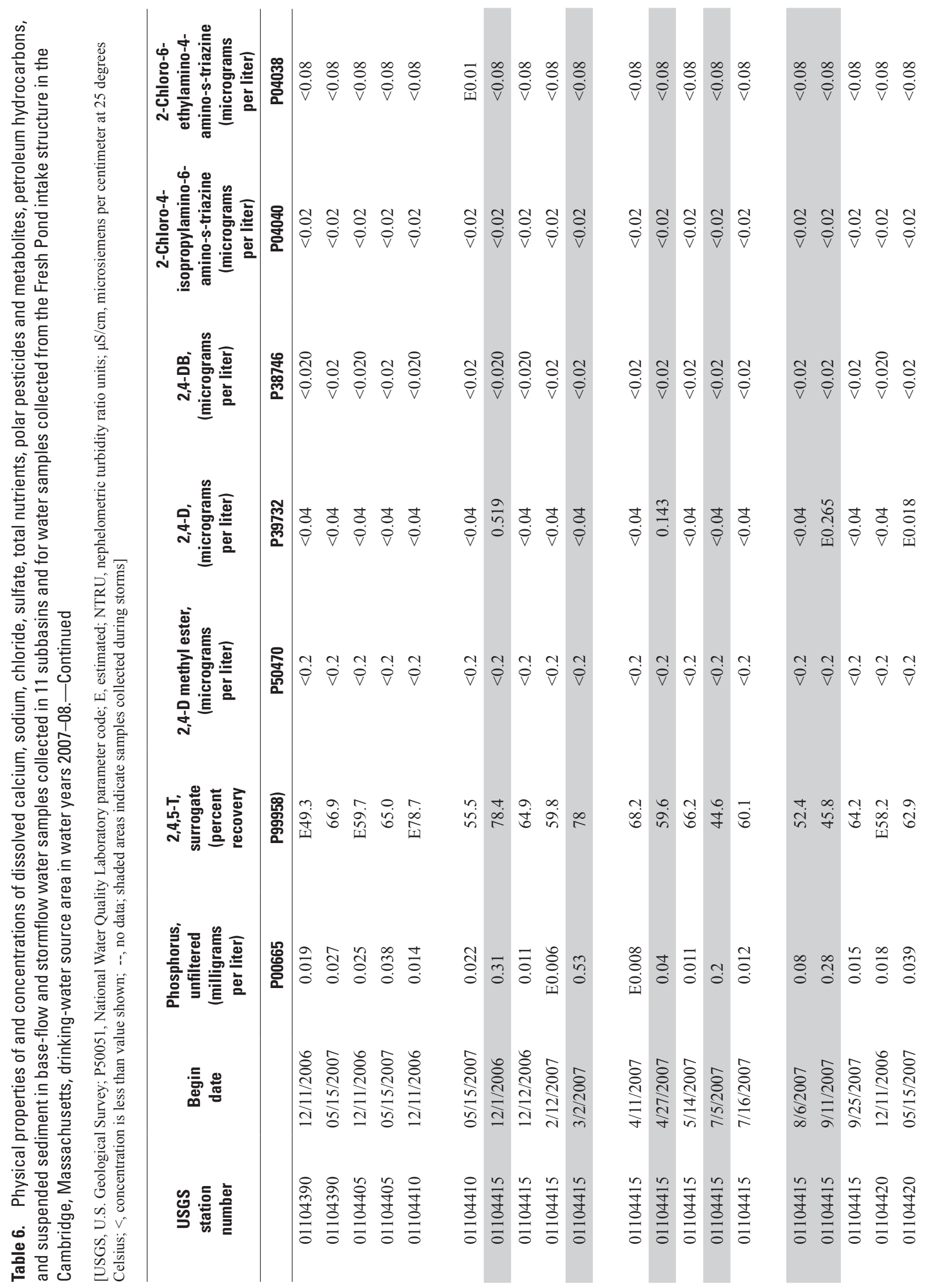




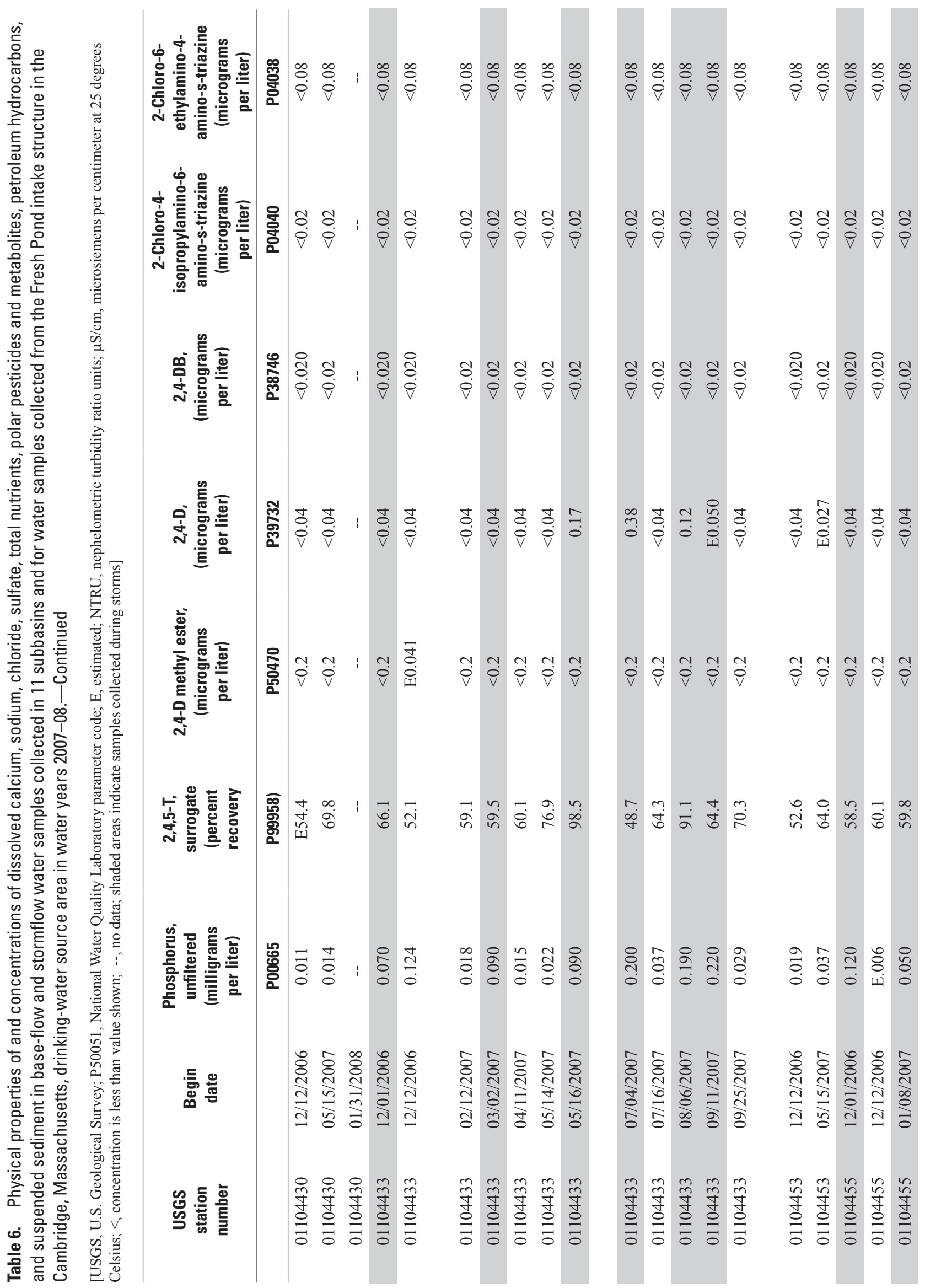




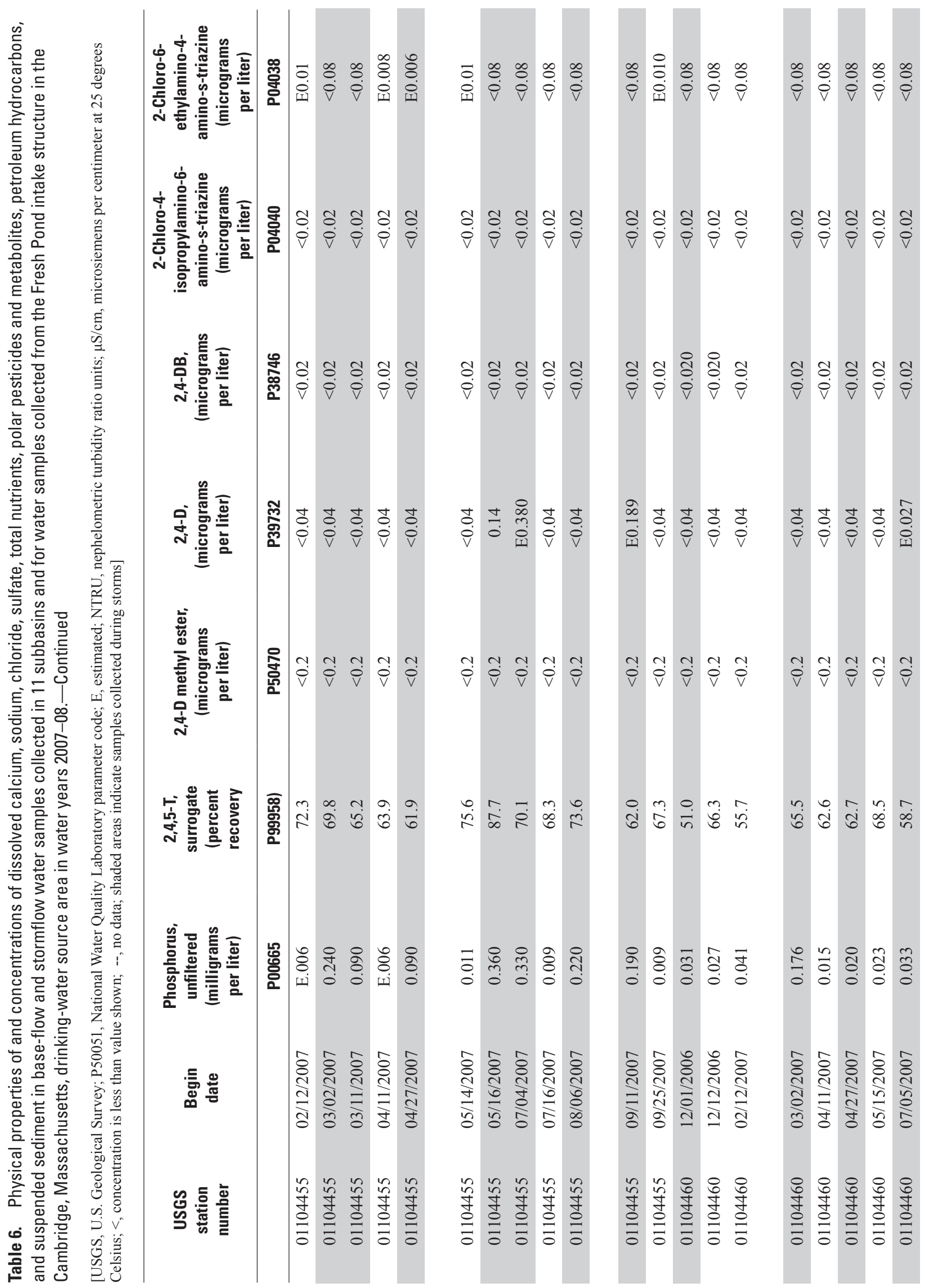


Table 6

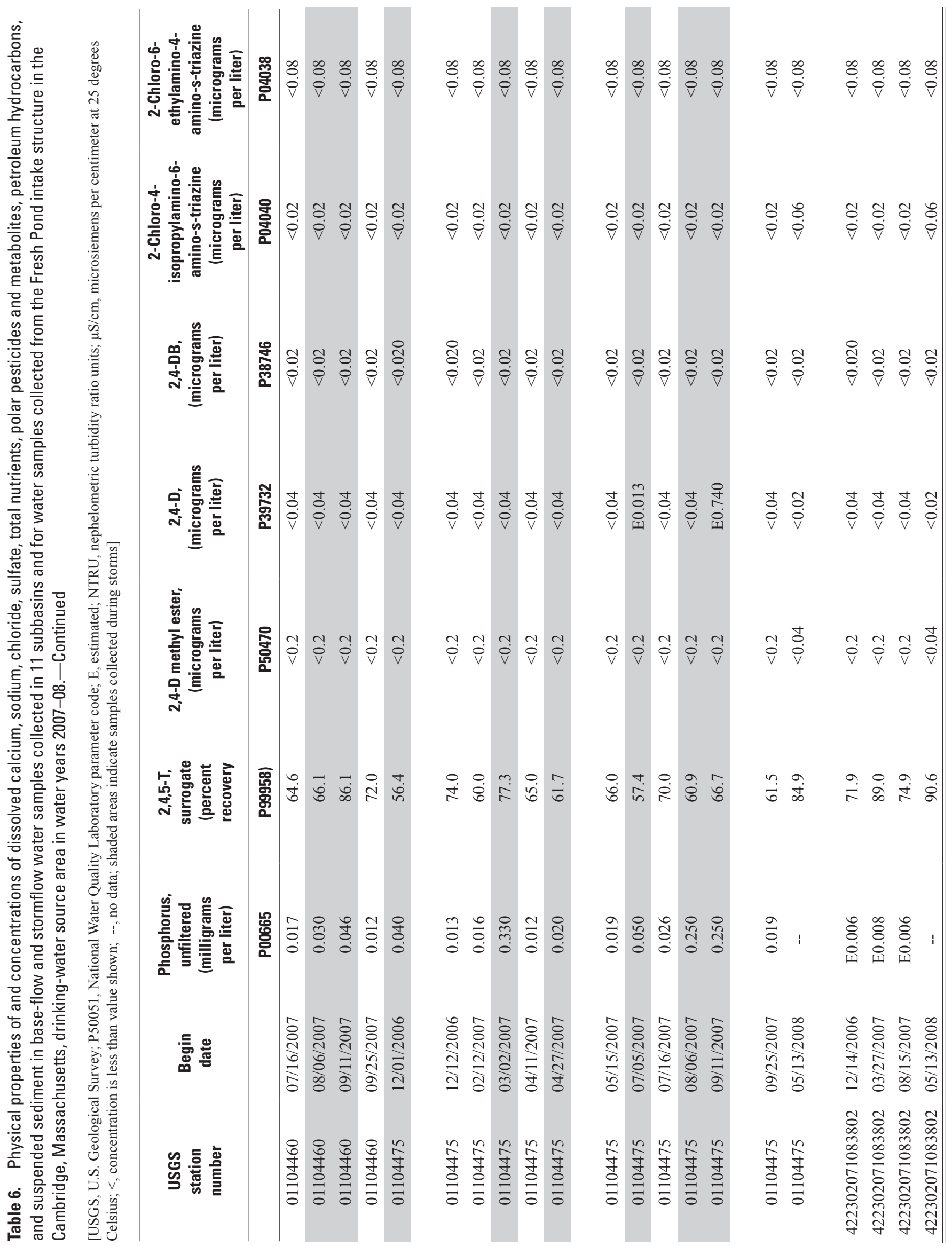




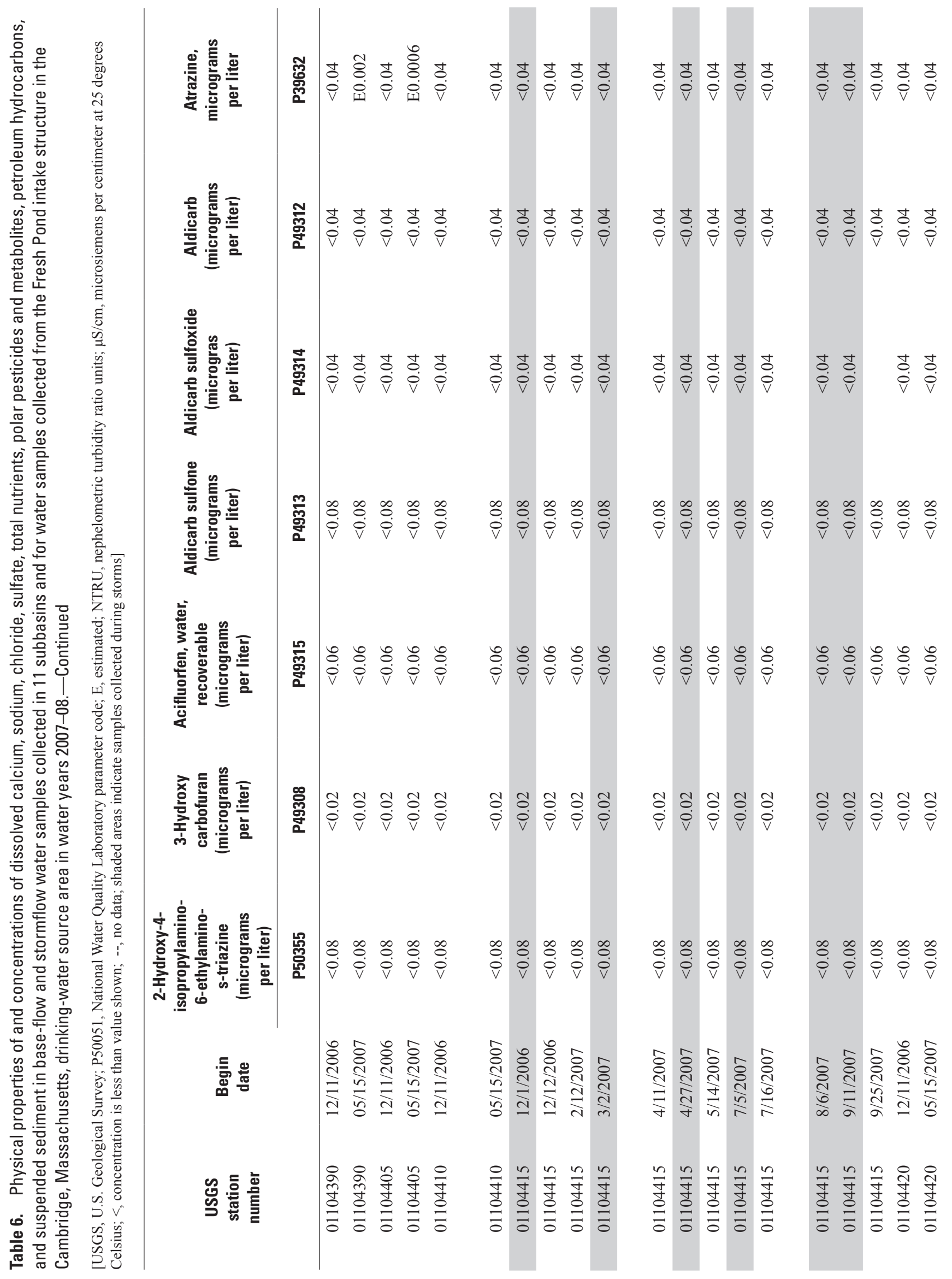




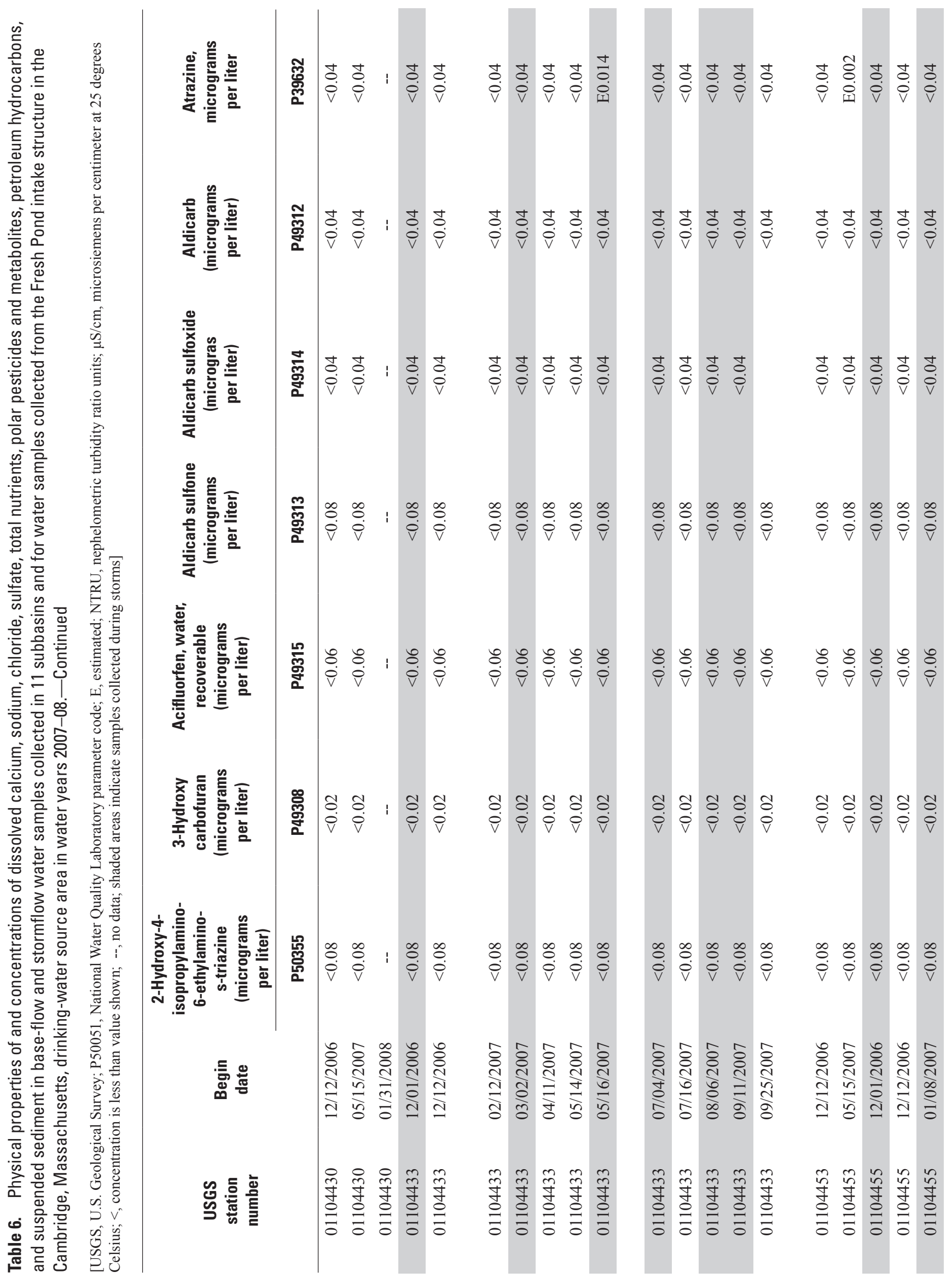




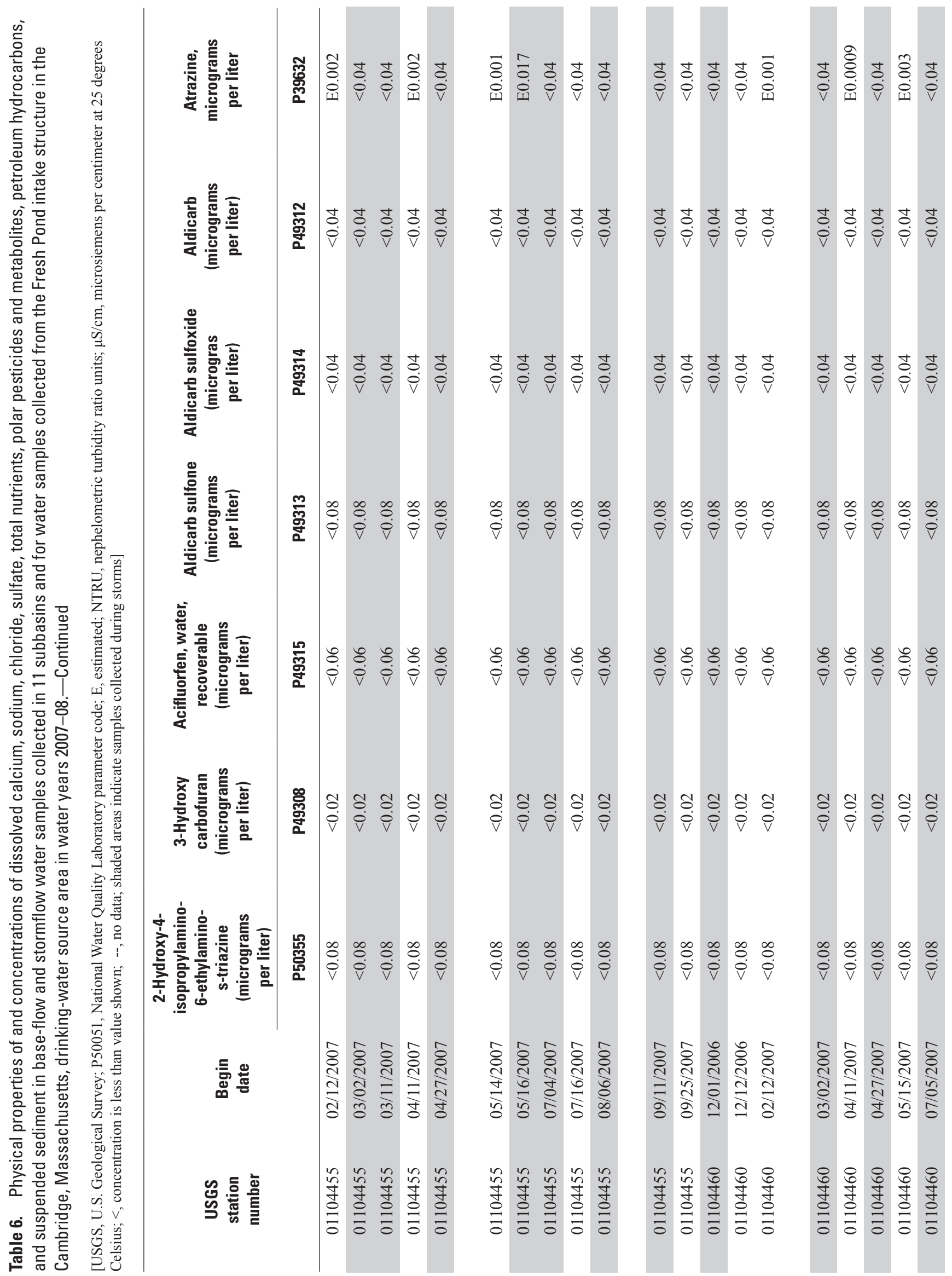




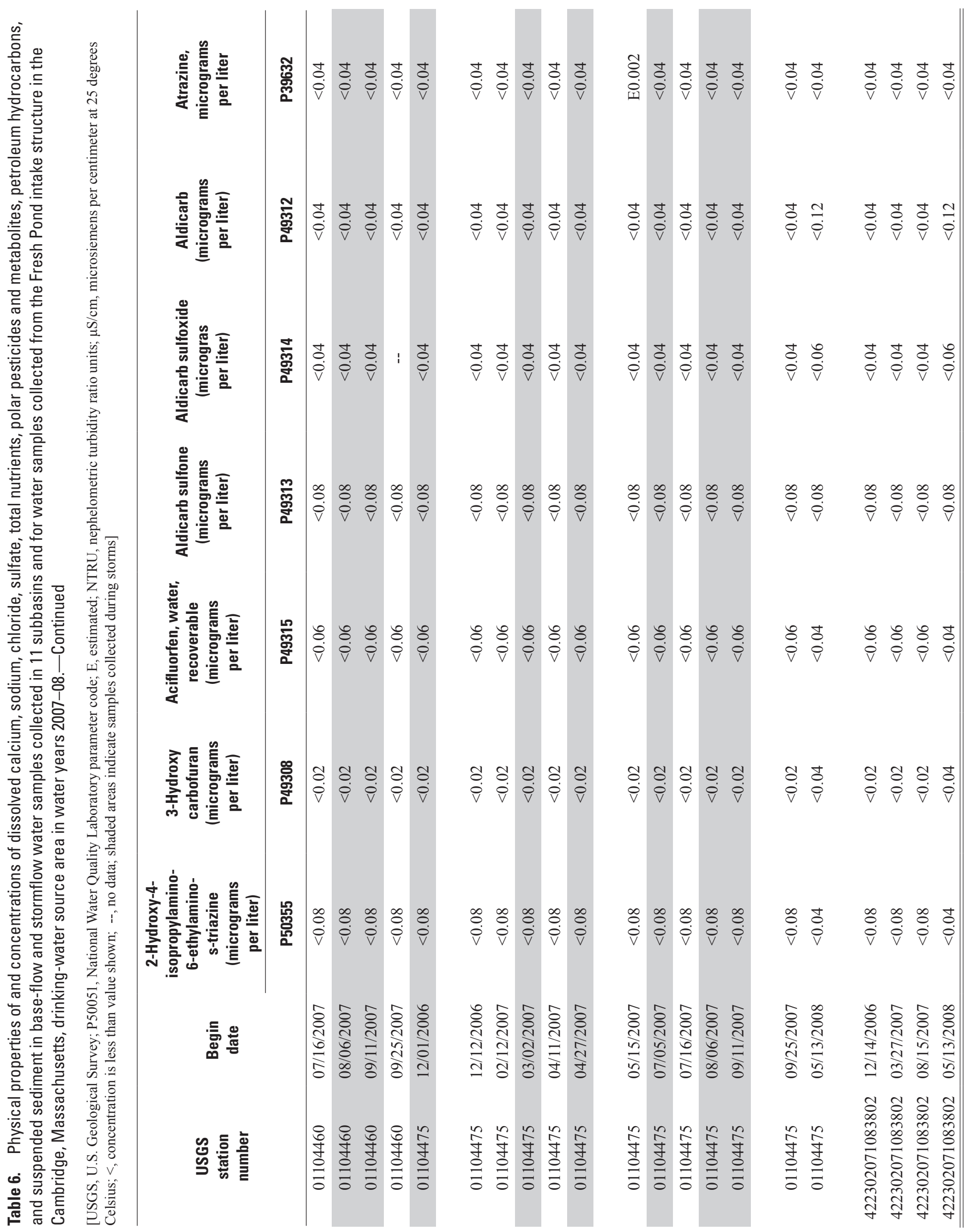




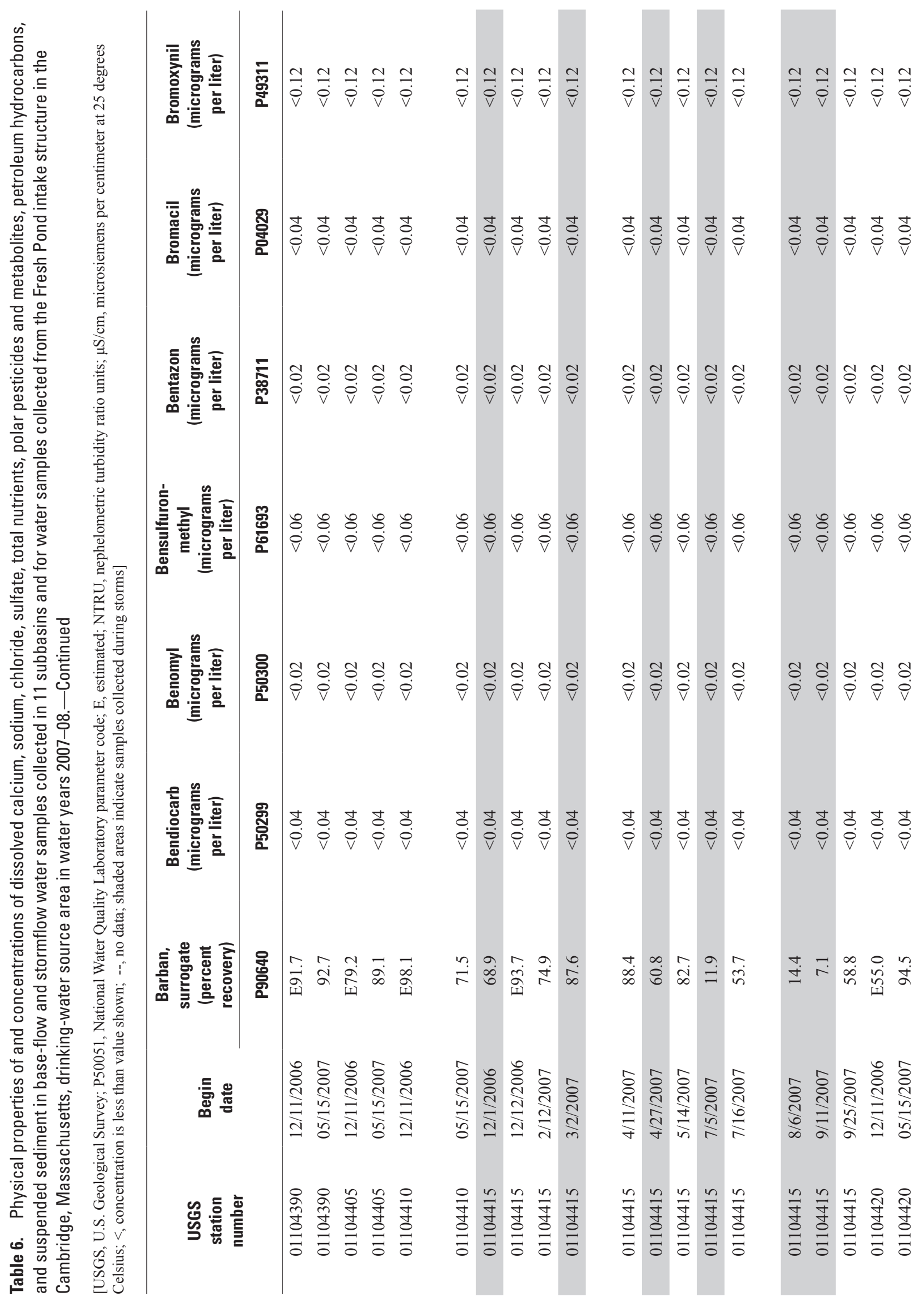




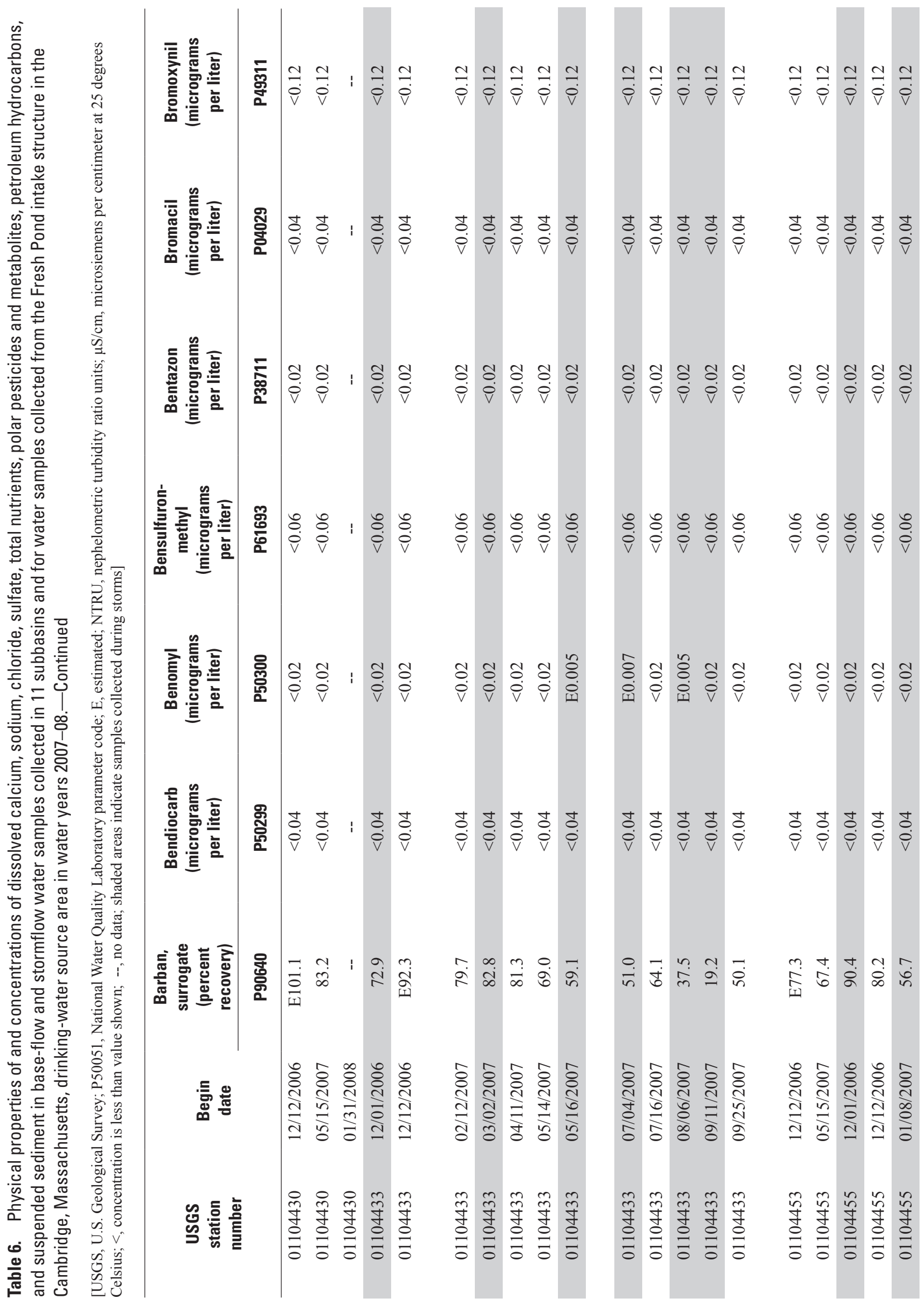




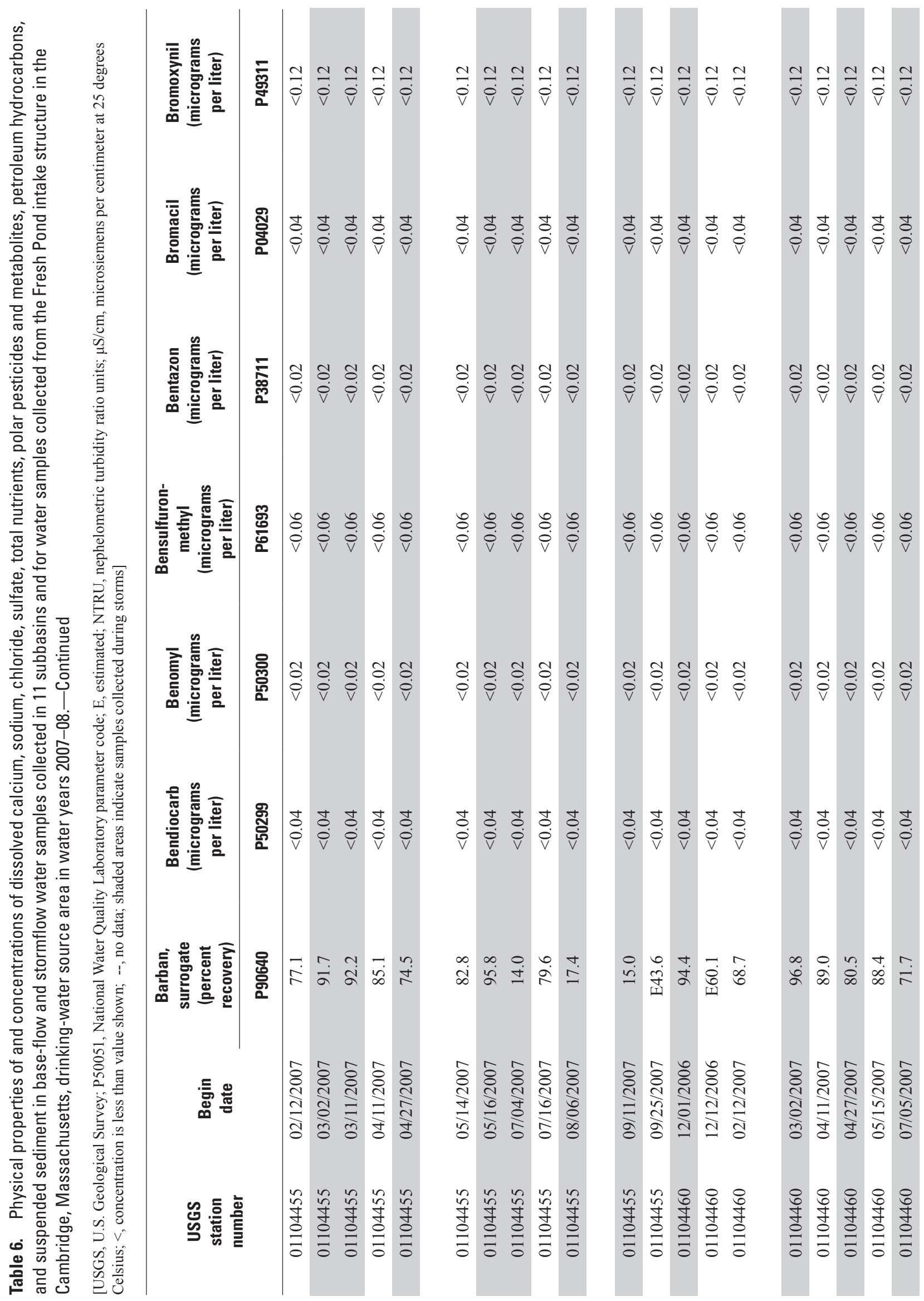




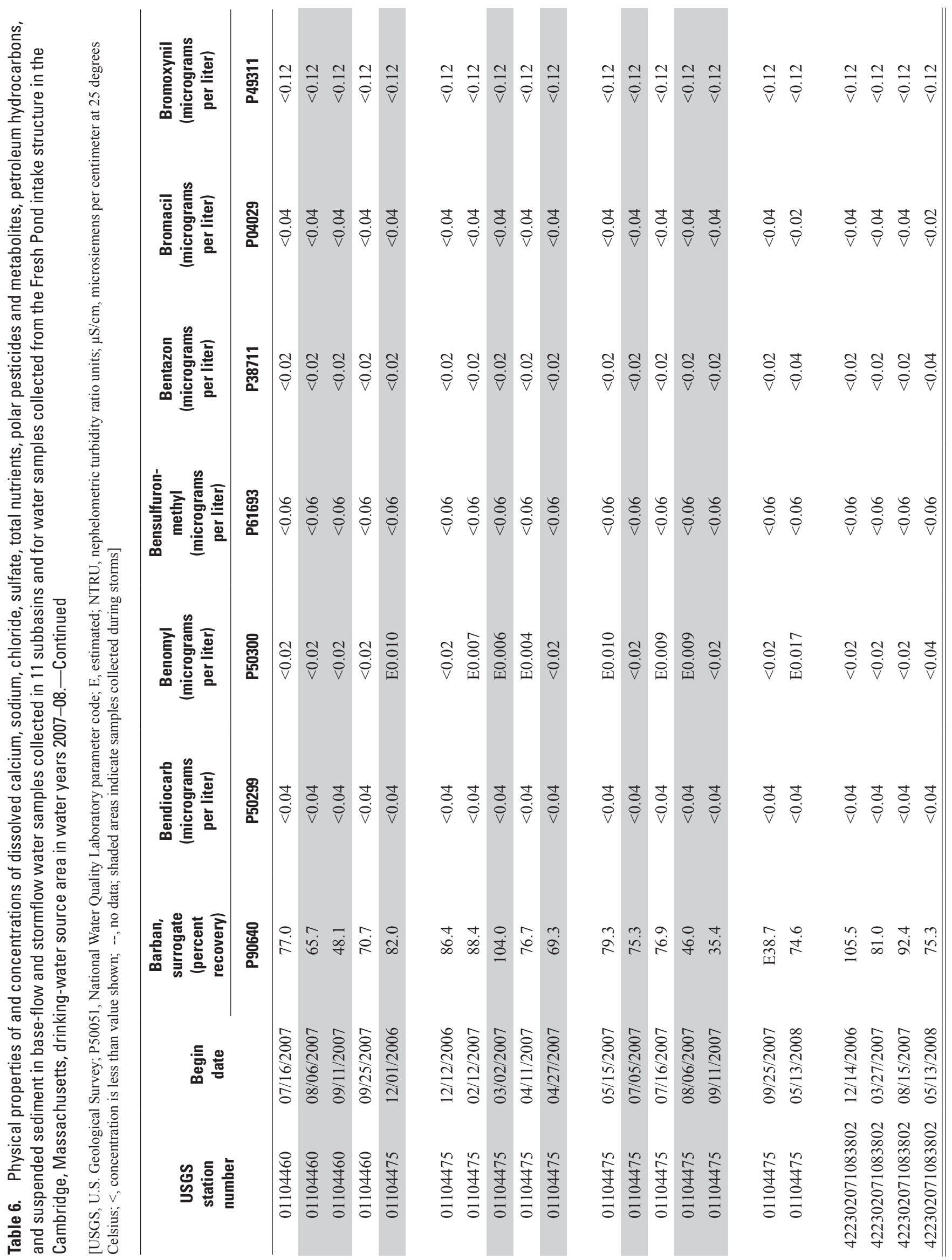




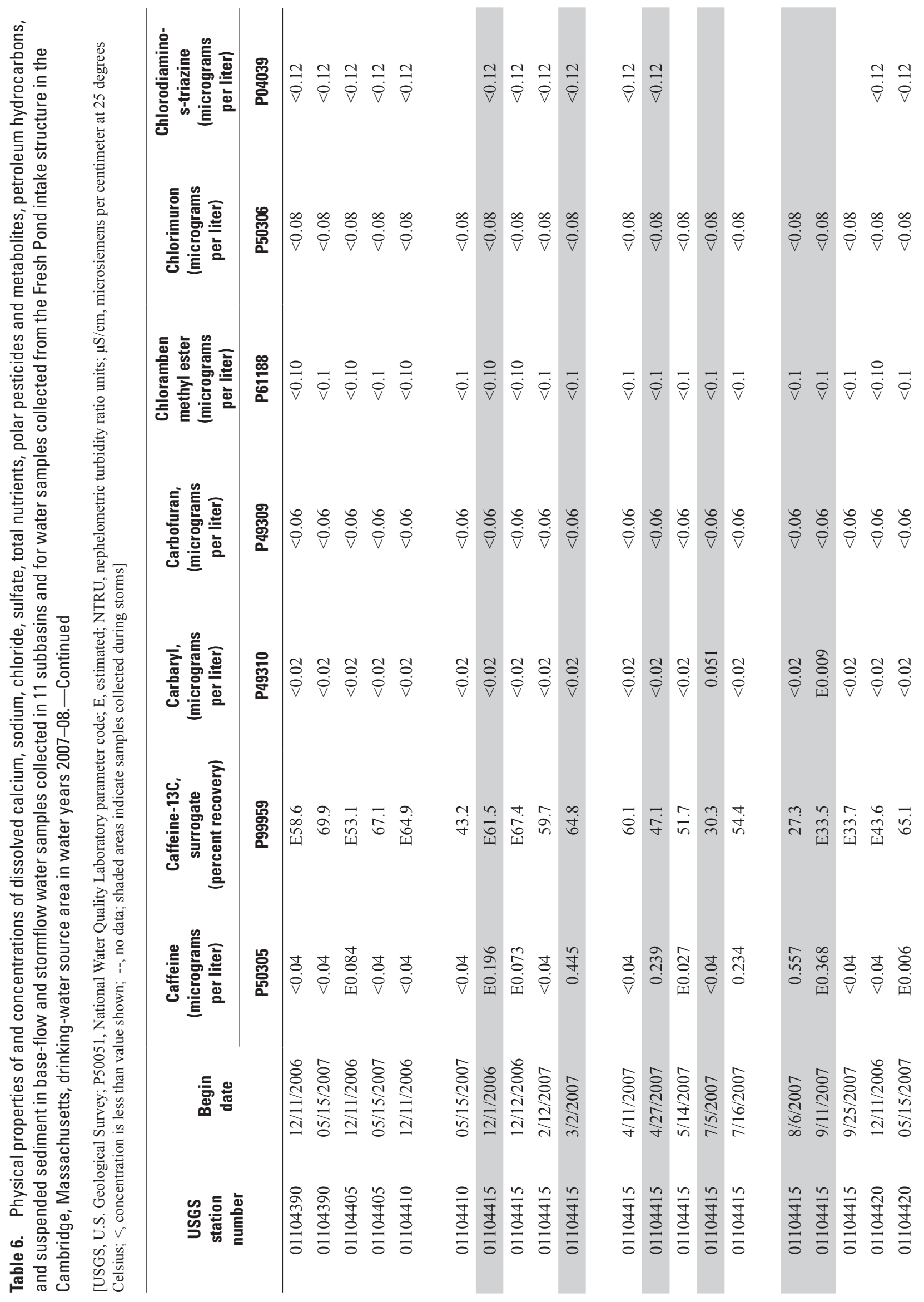




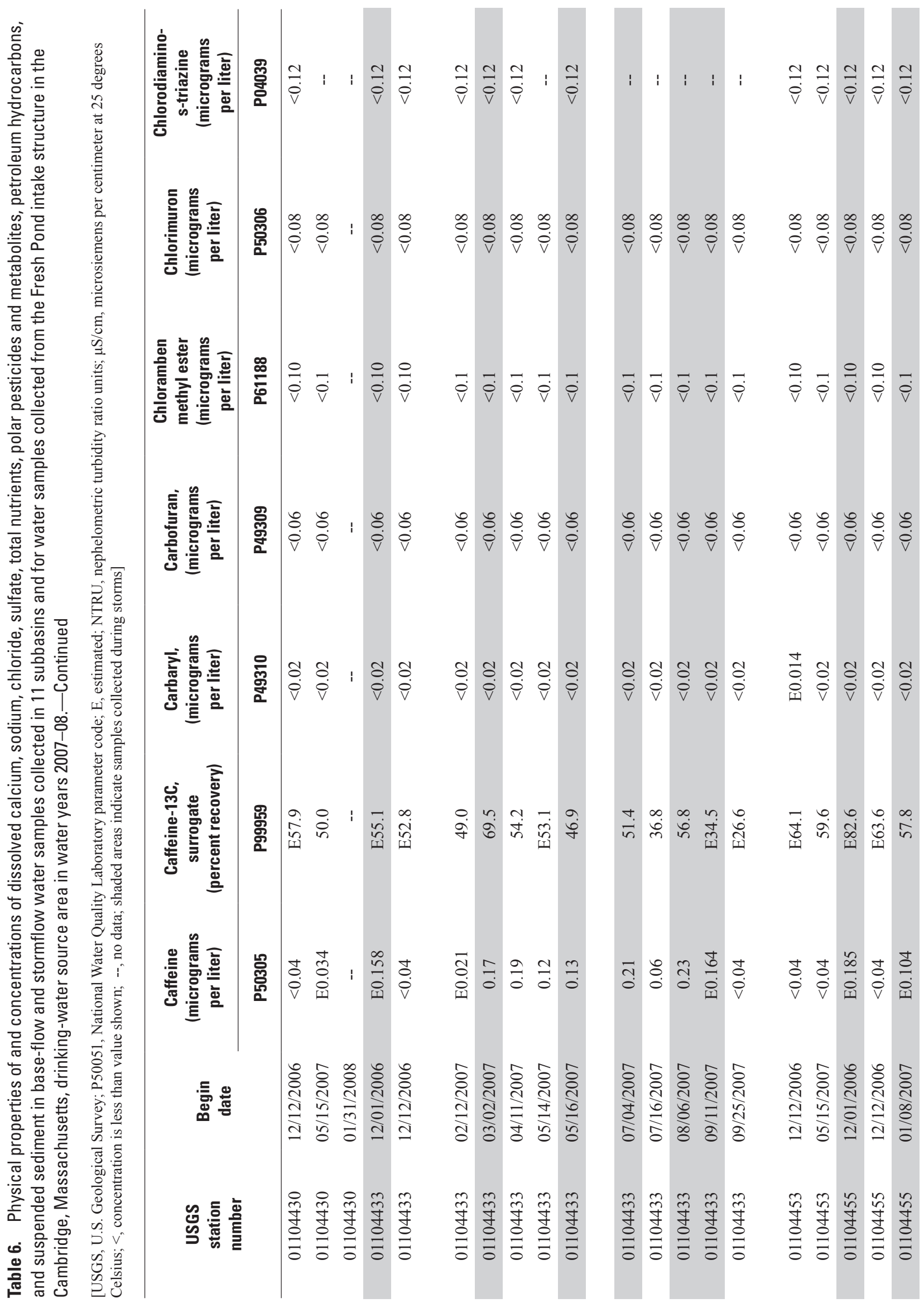




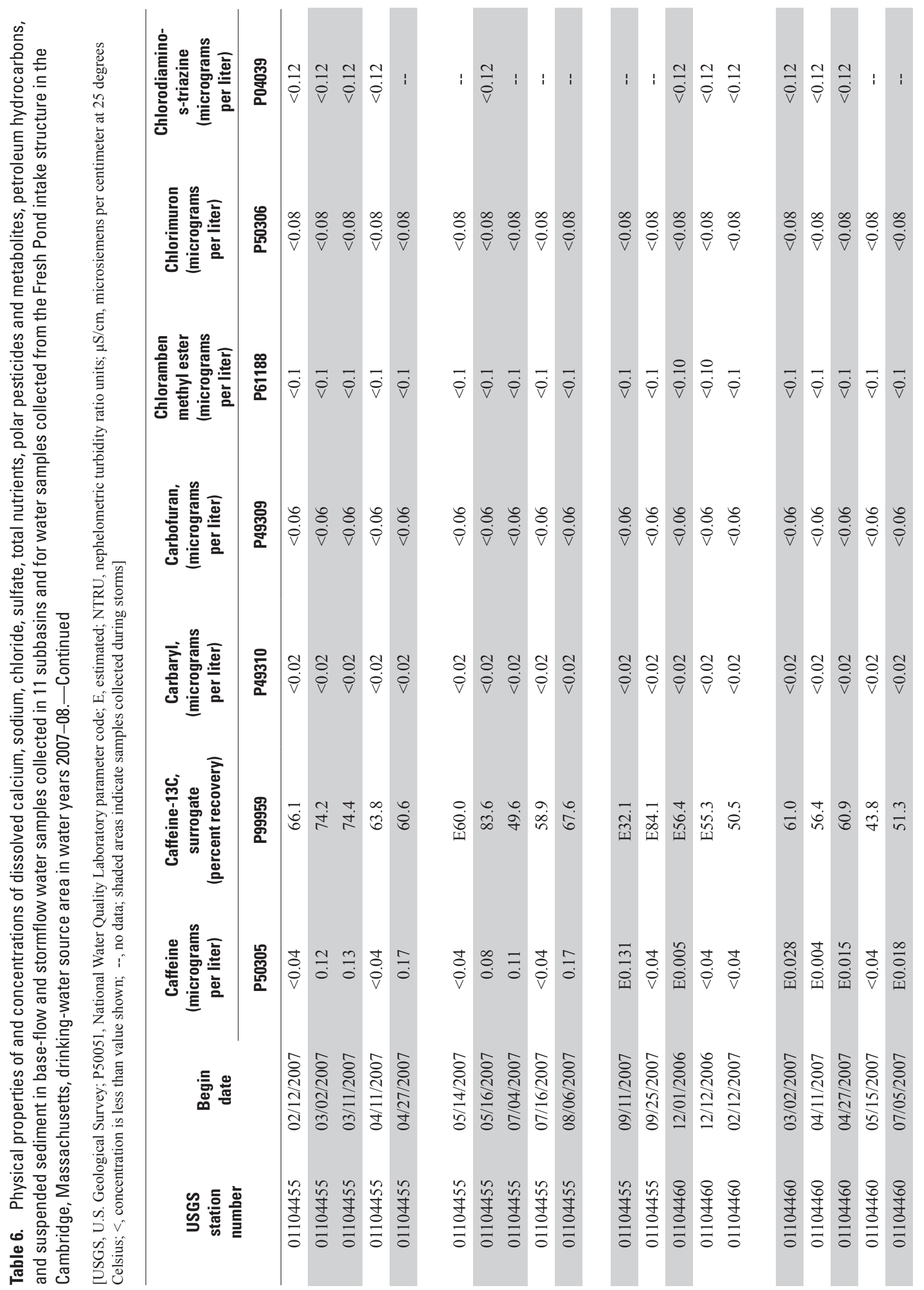




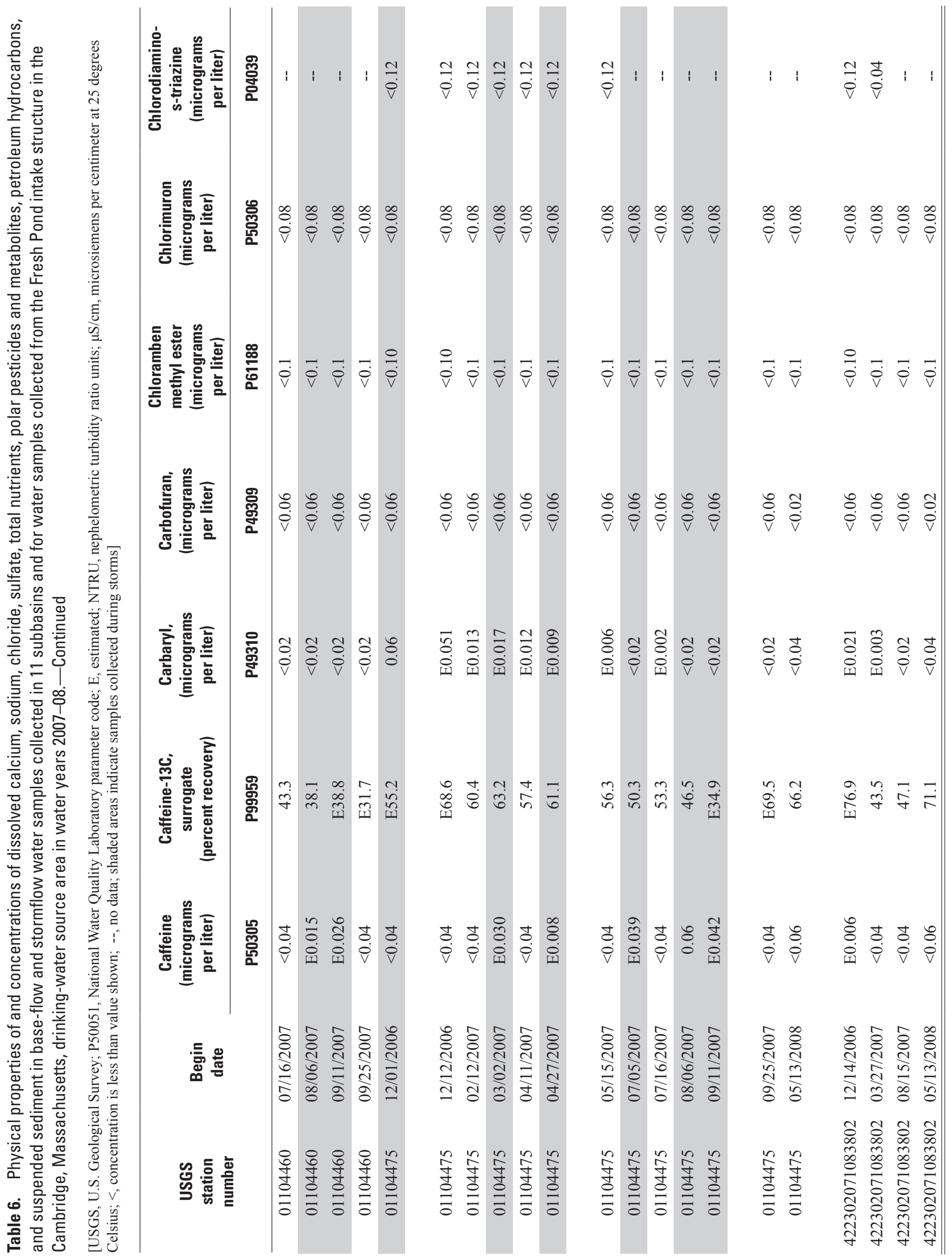




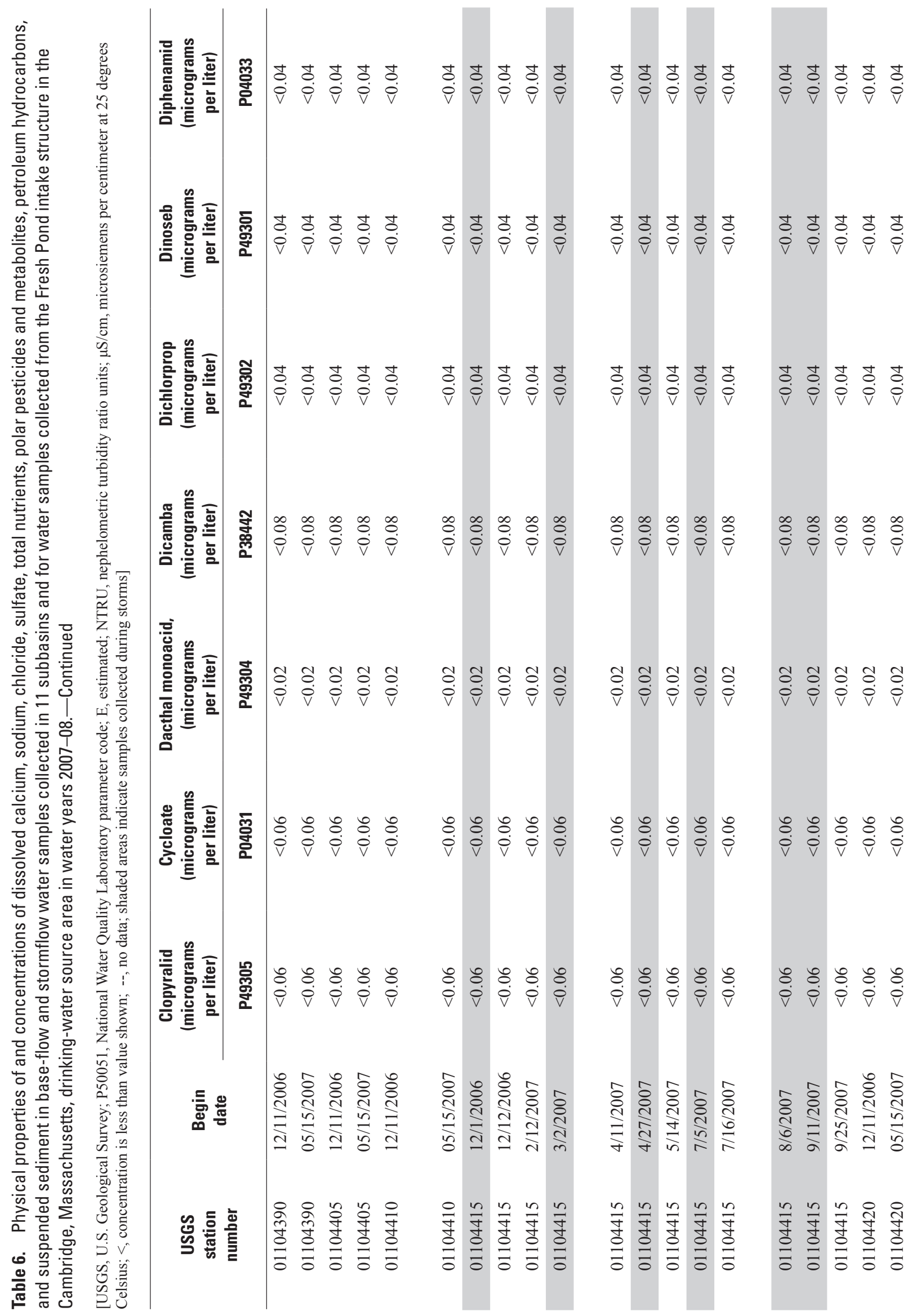




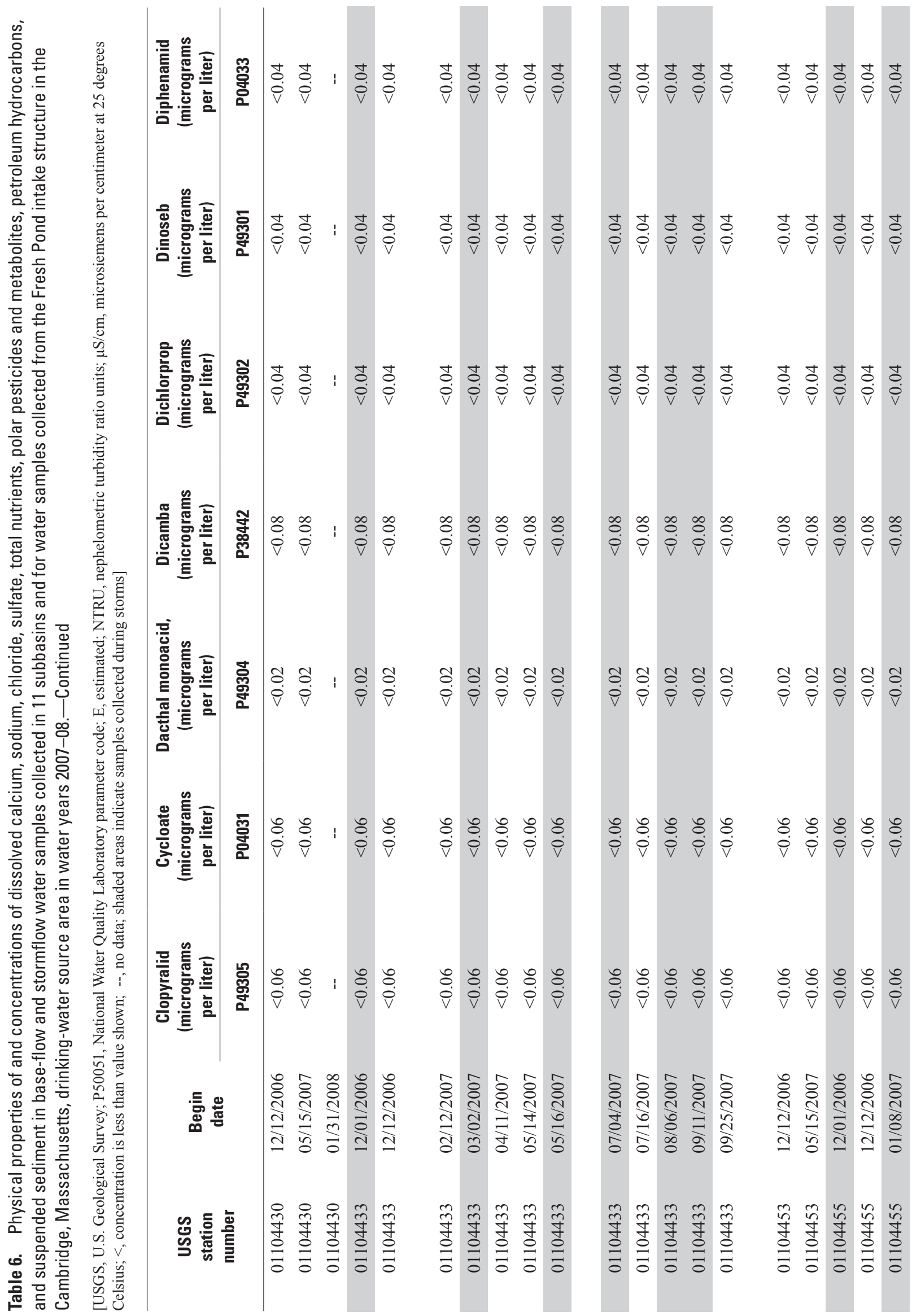




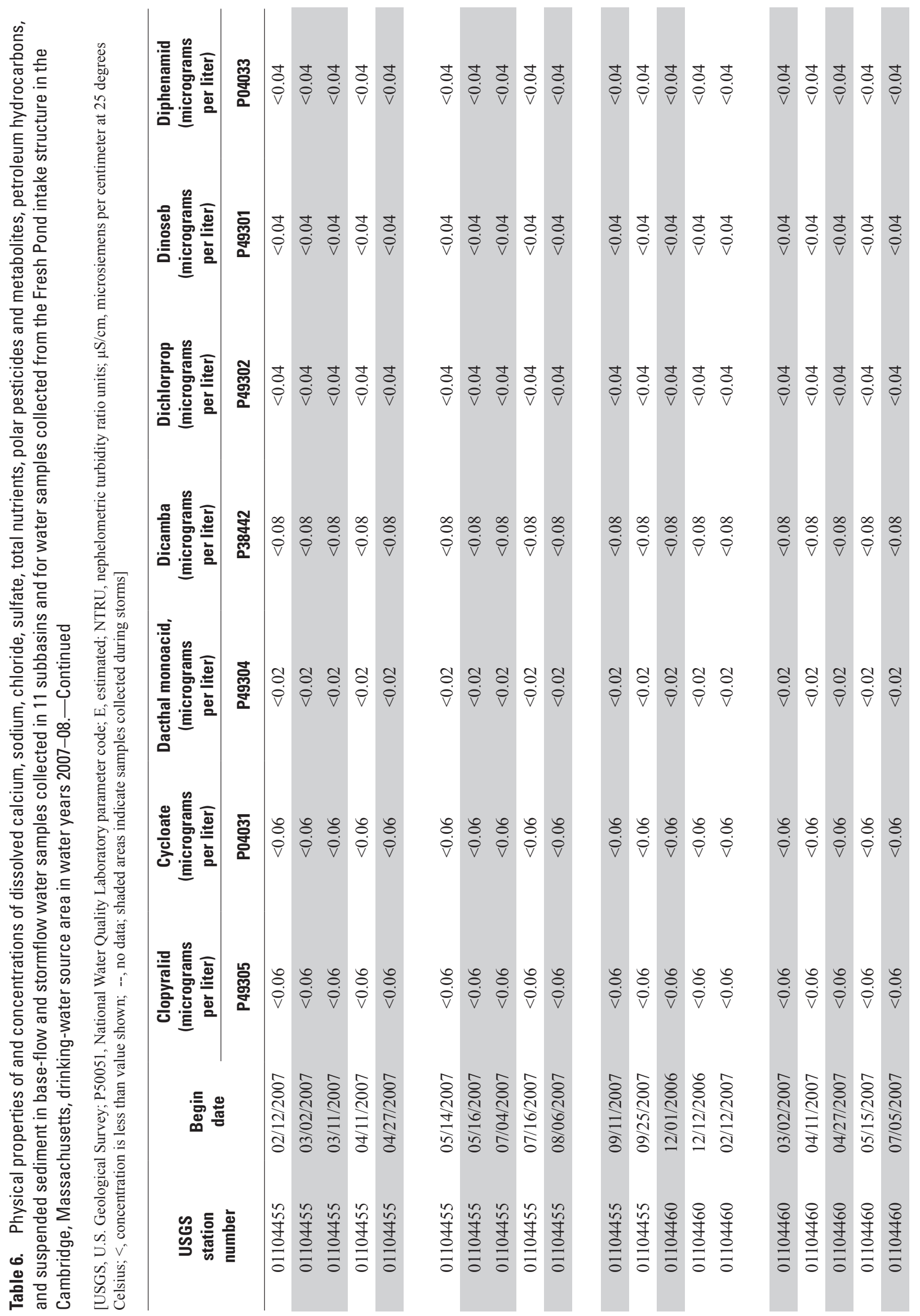




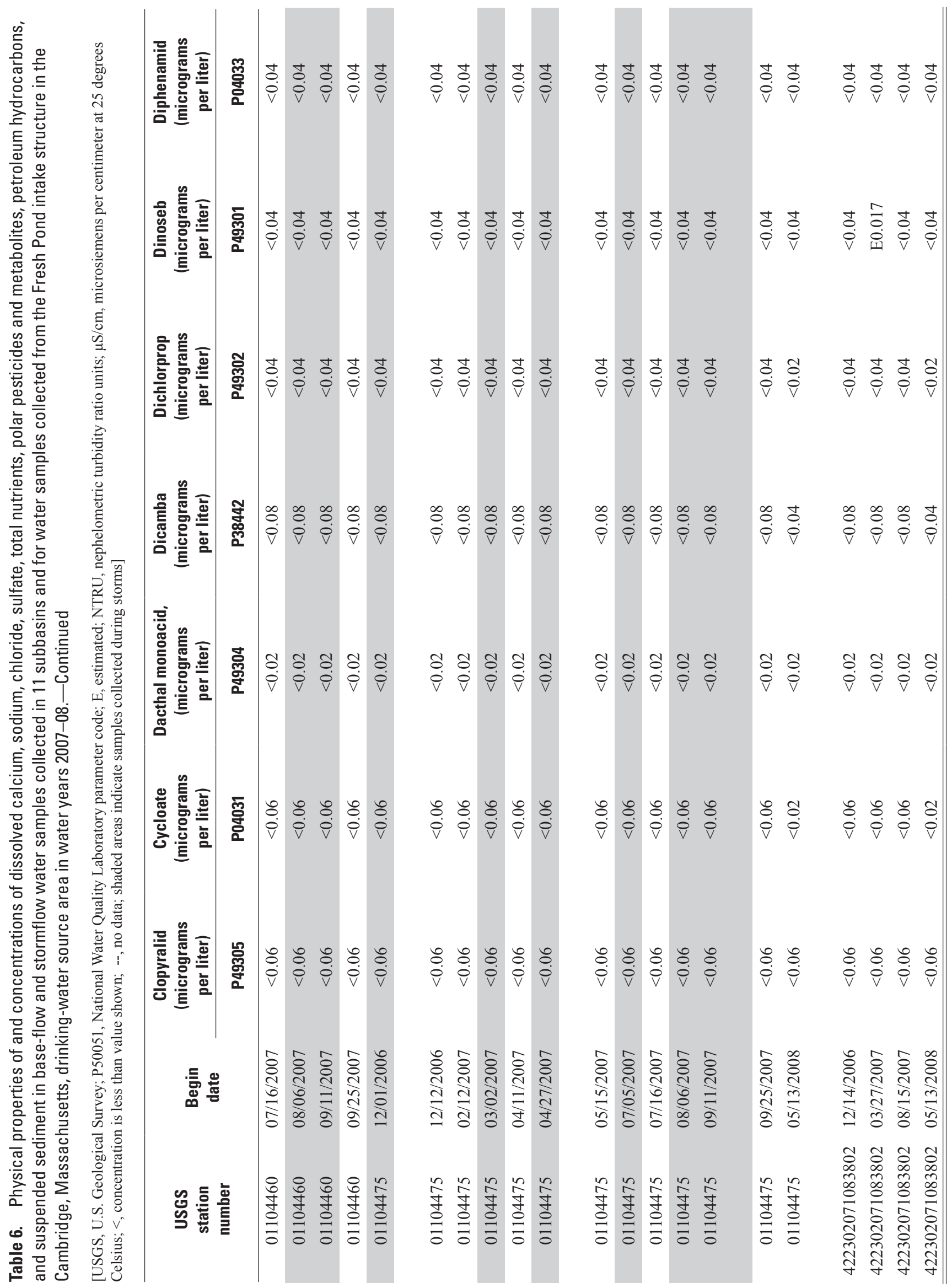




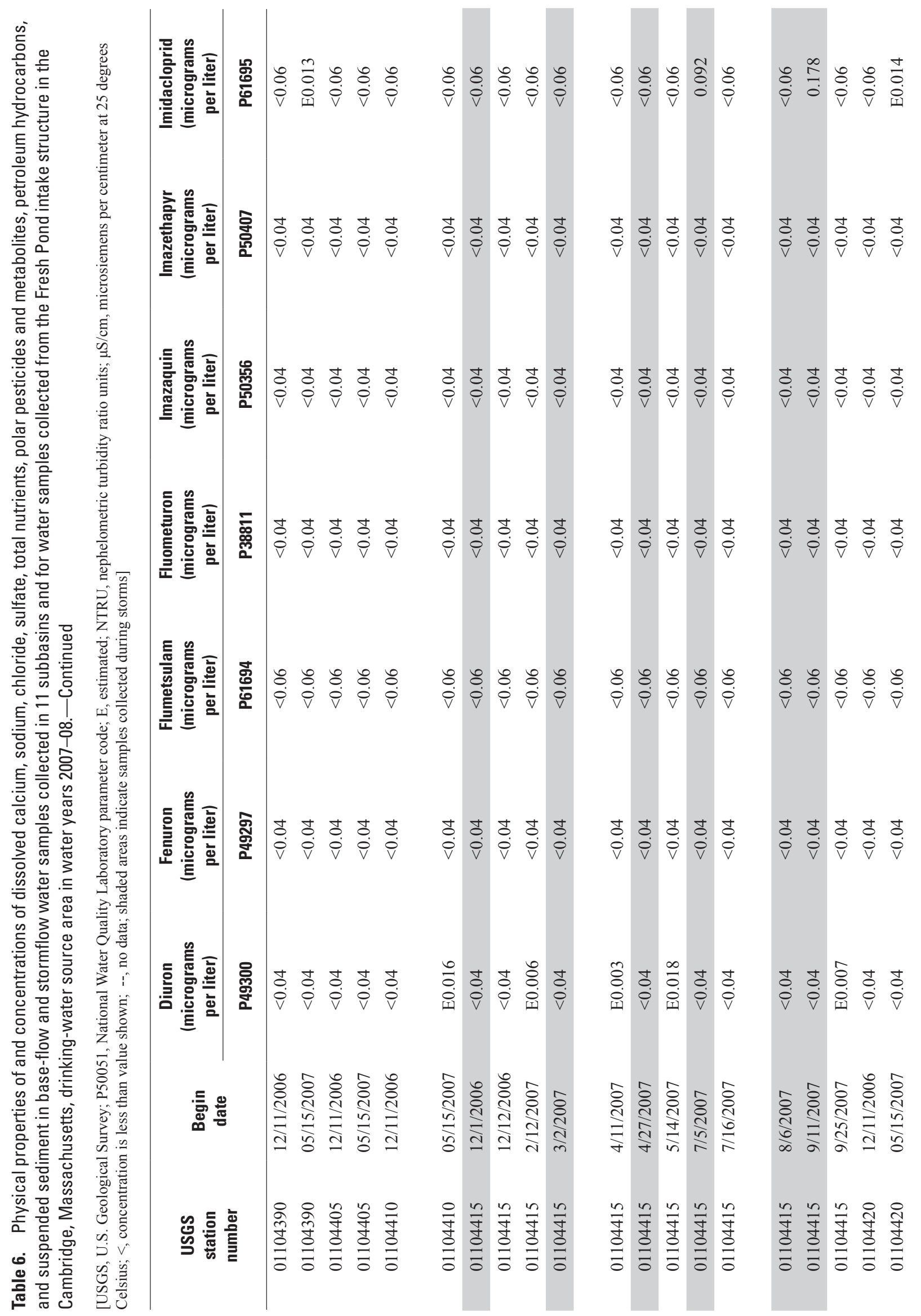




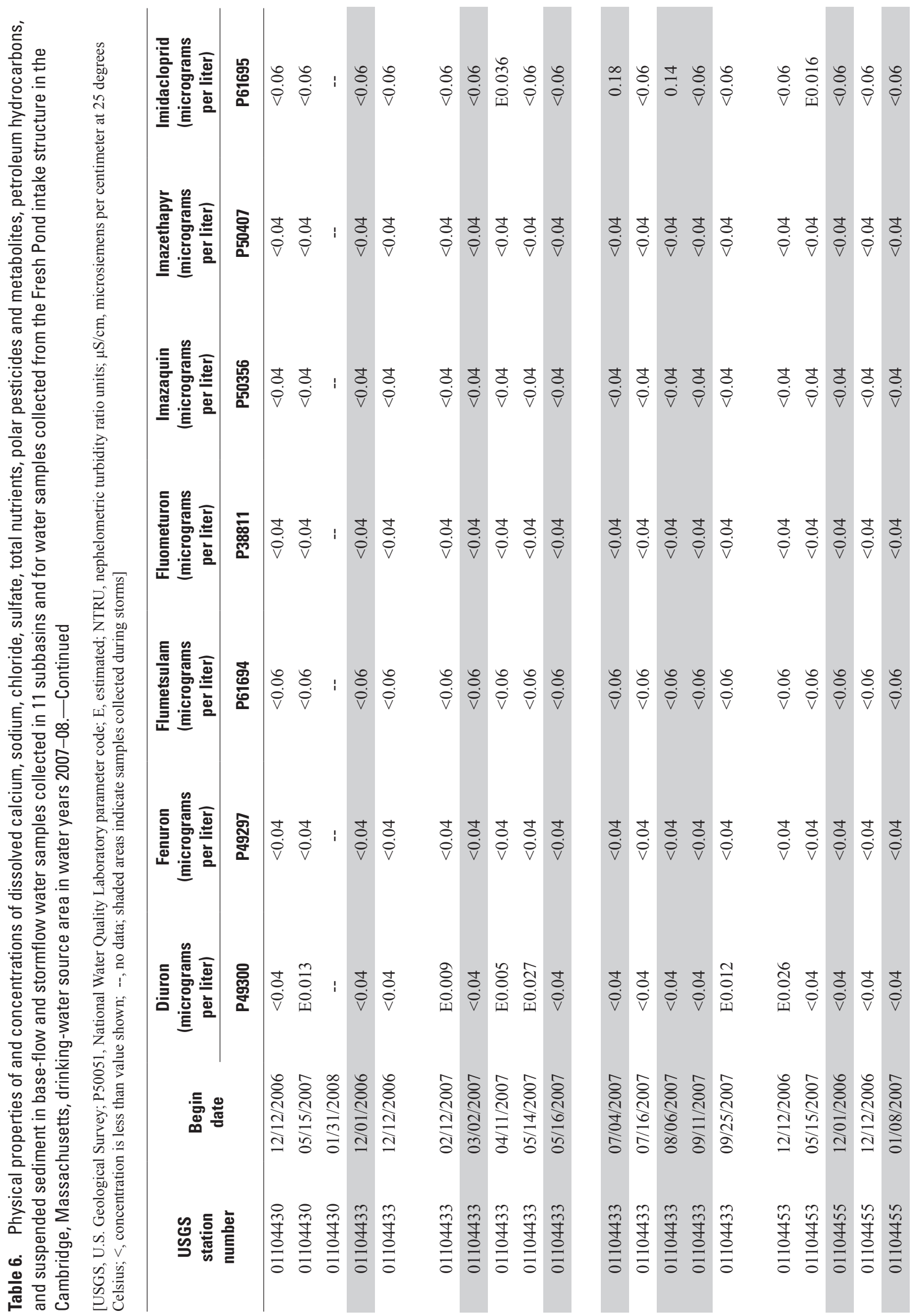




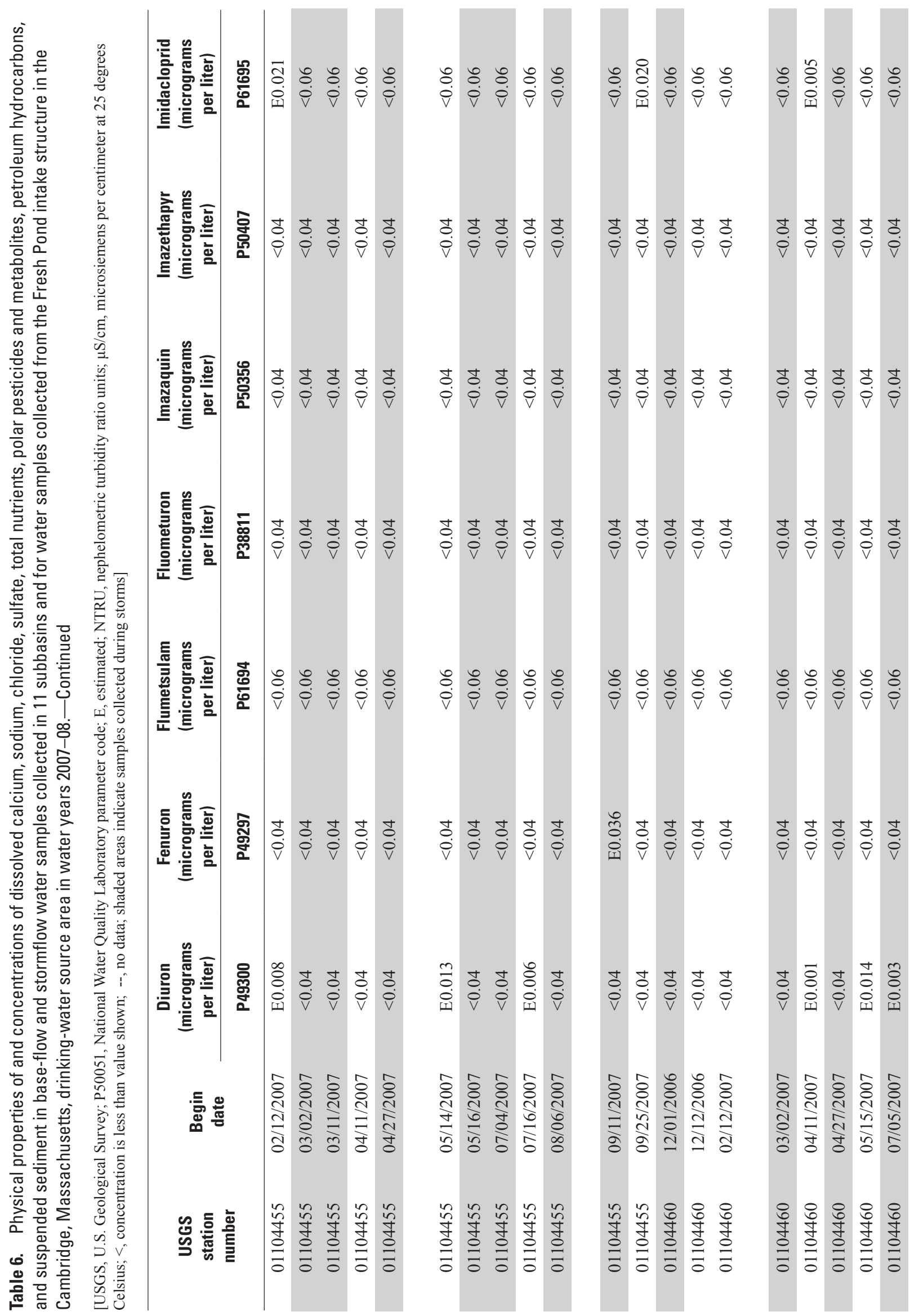




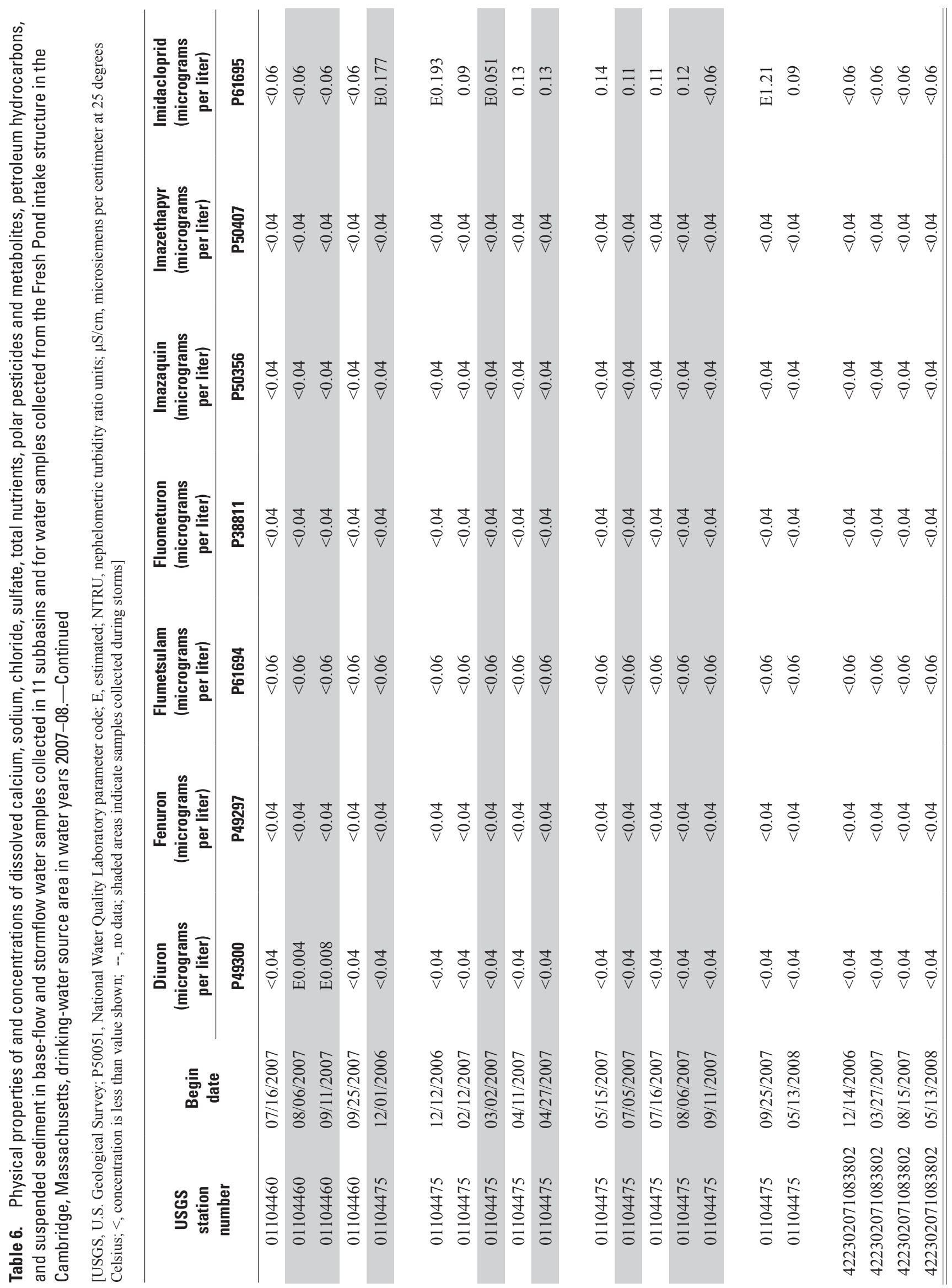




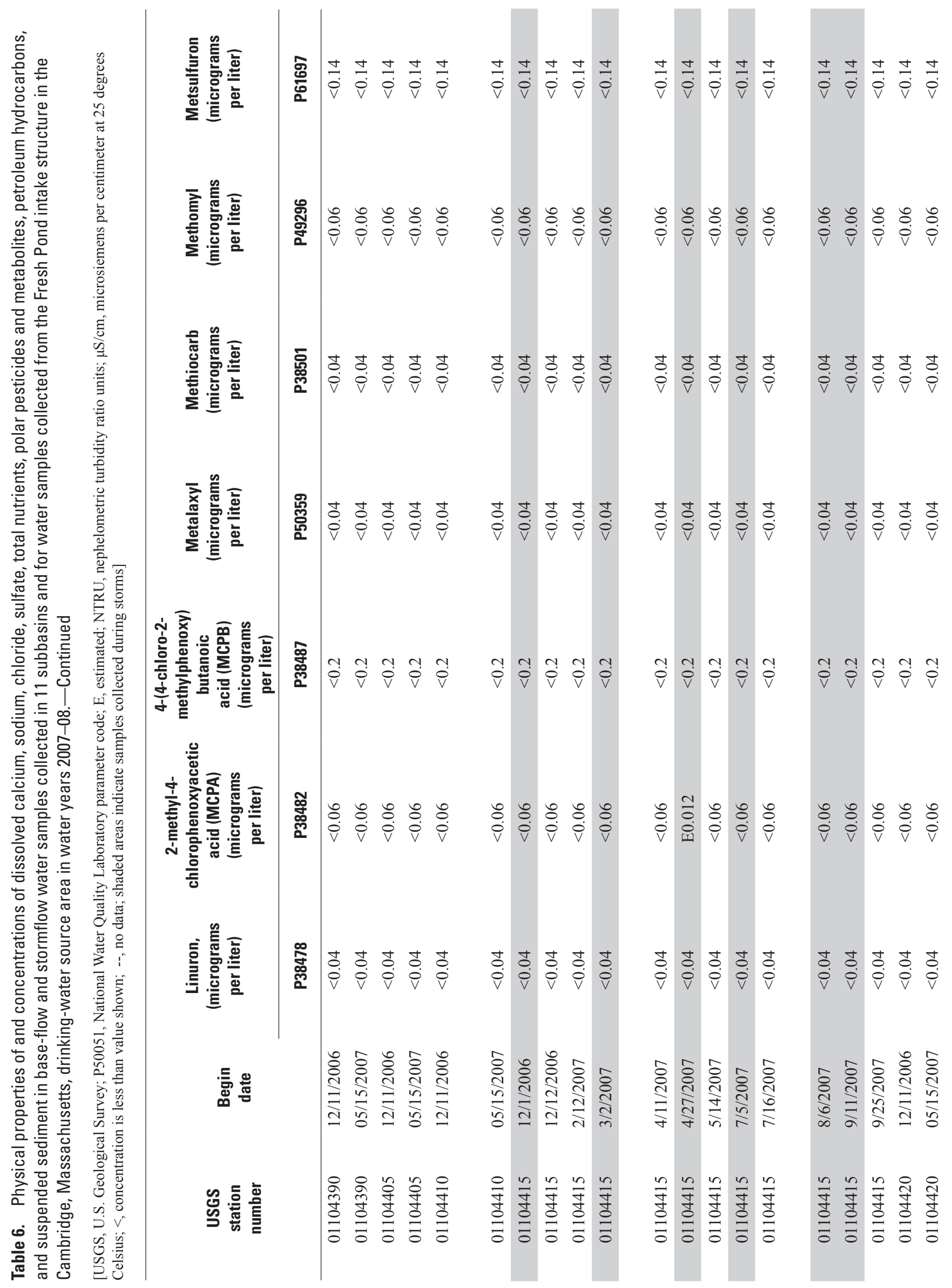




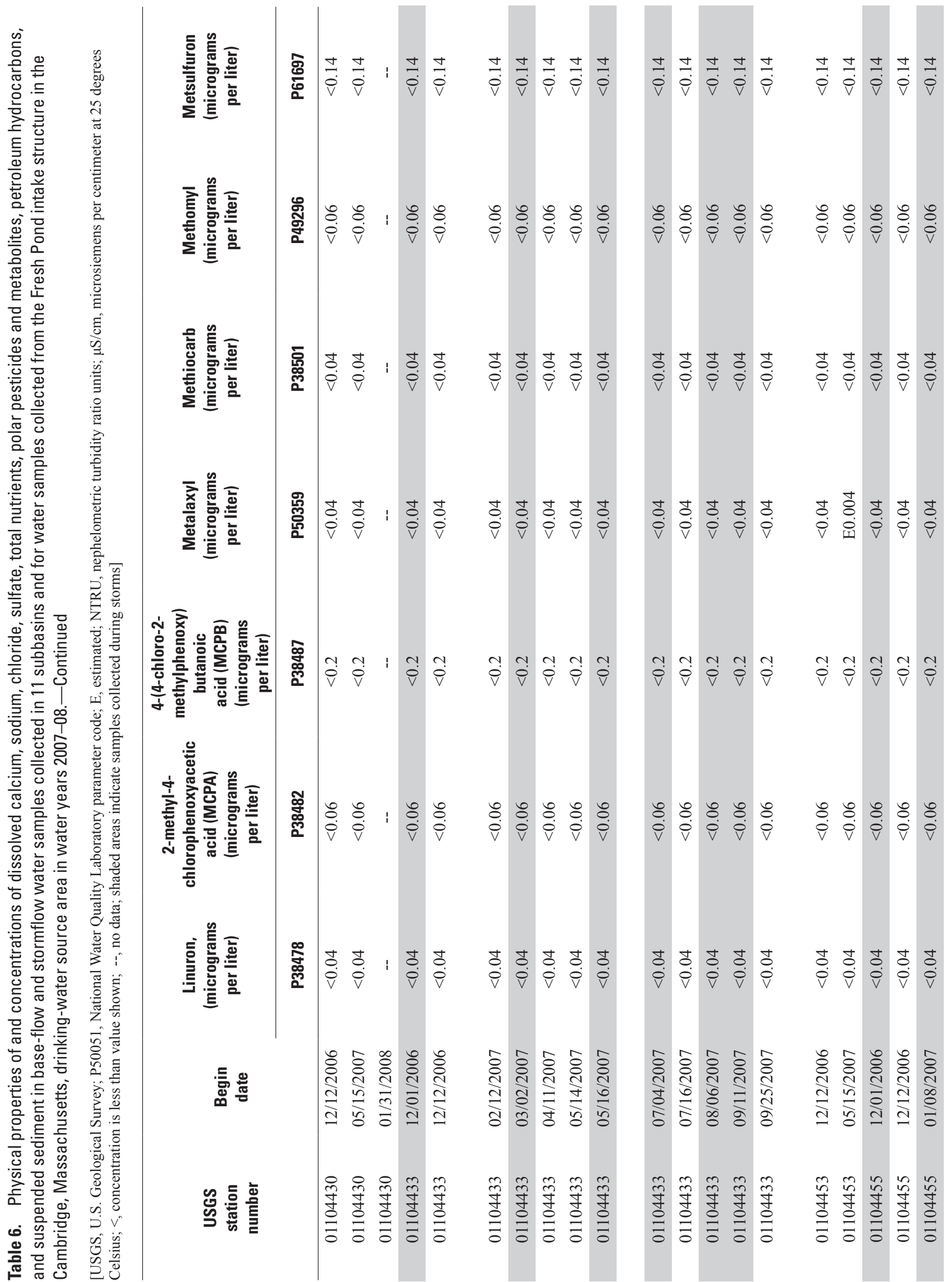




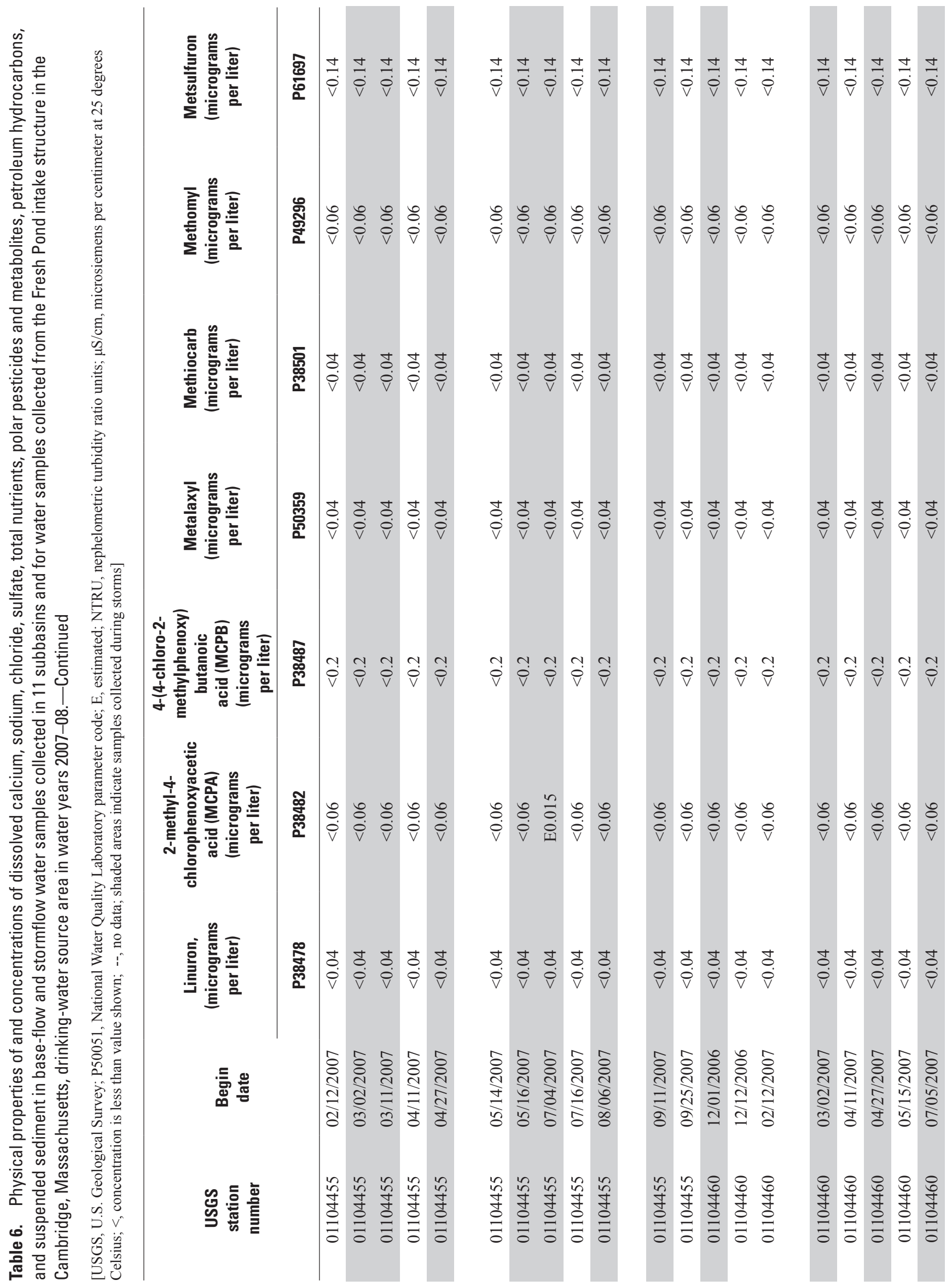




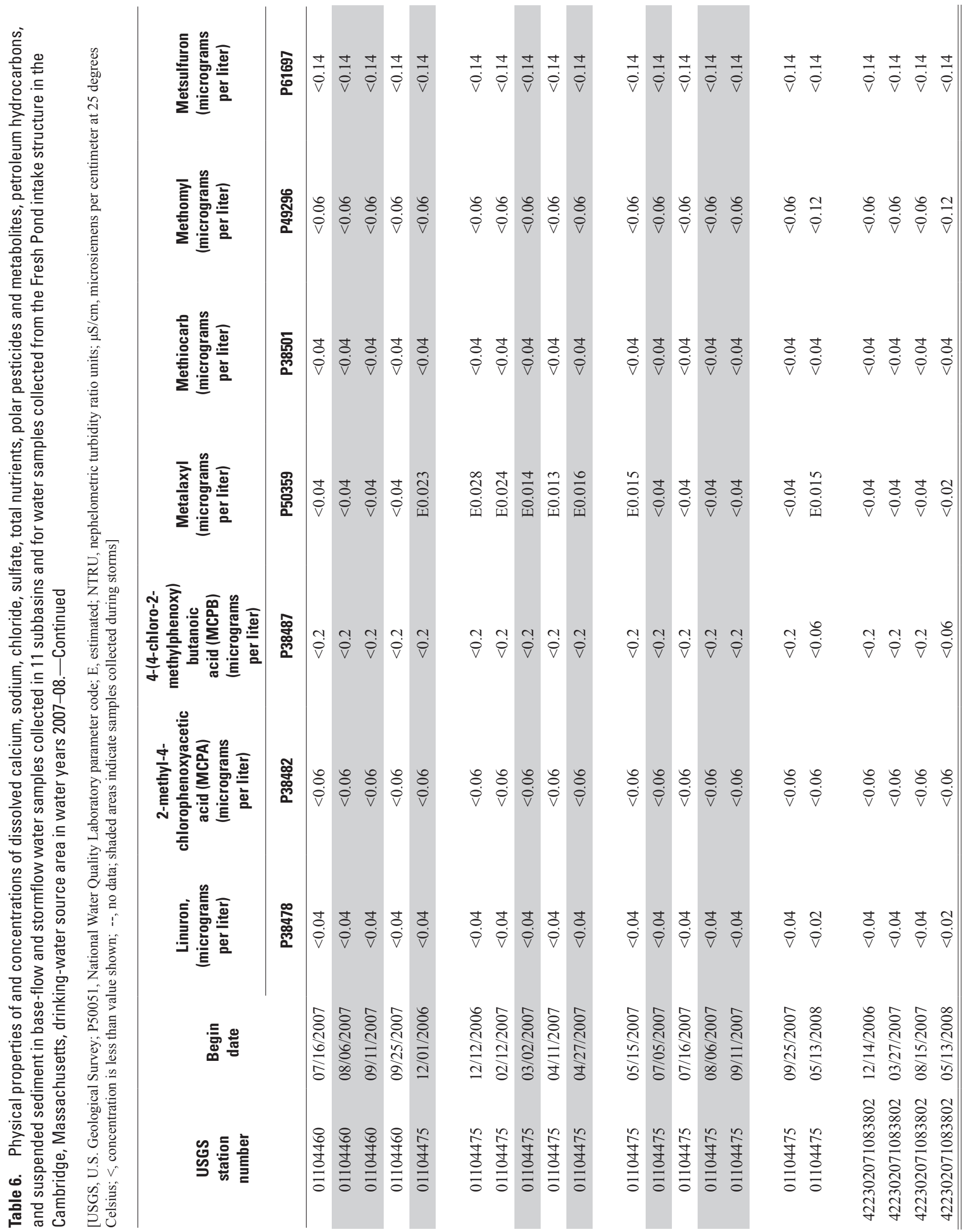




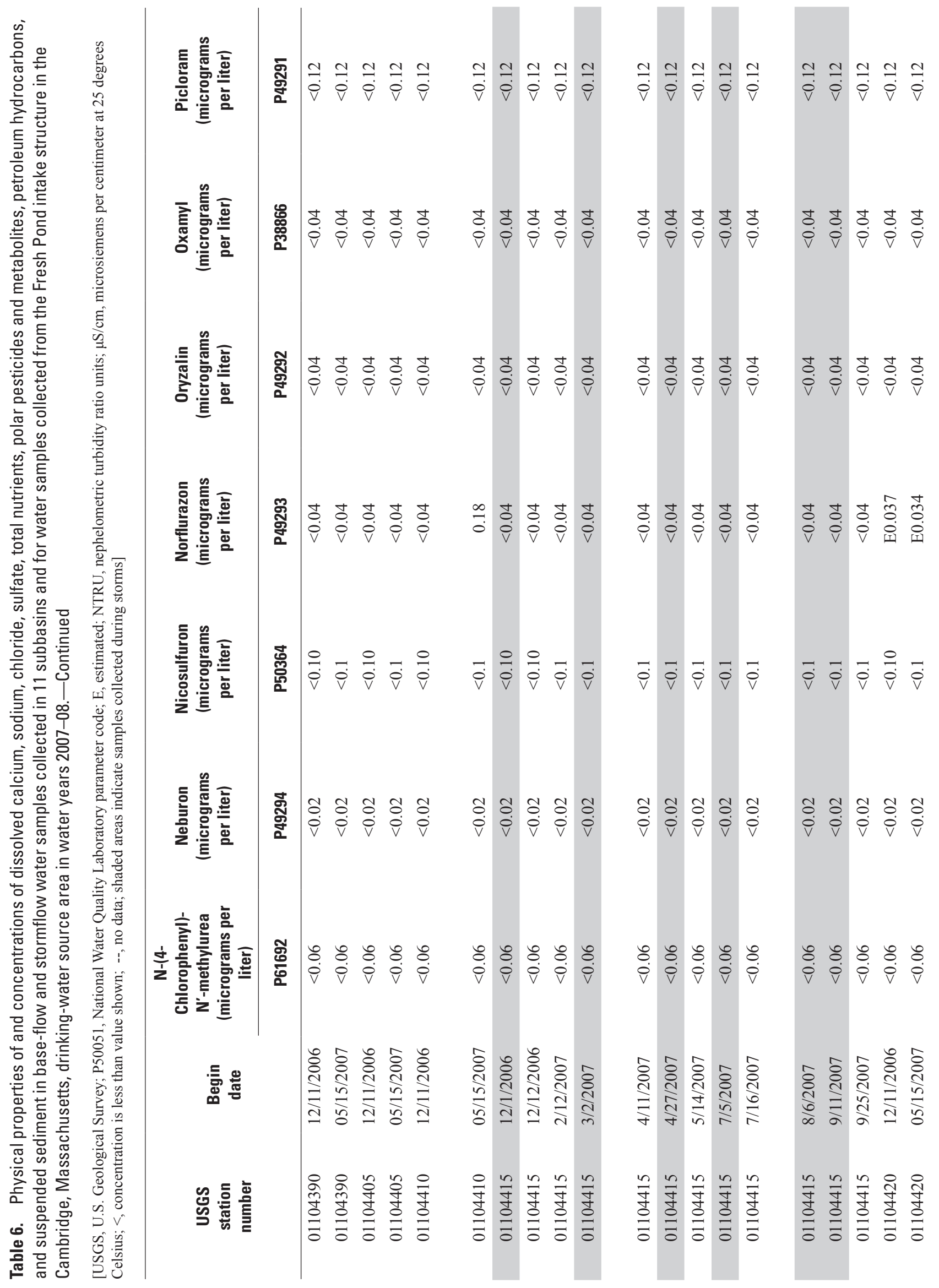




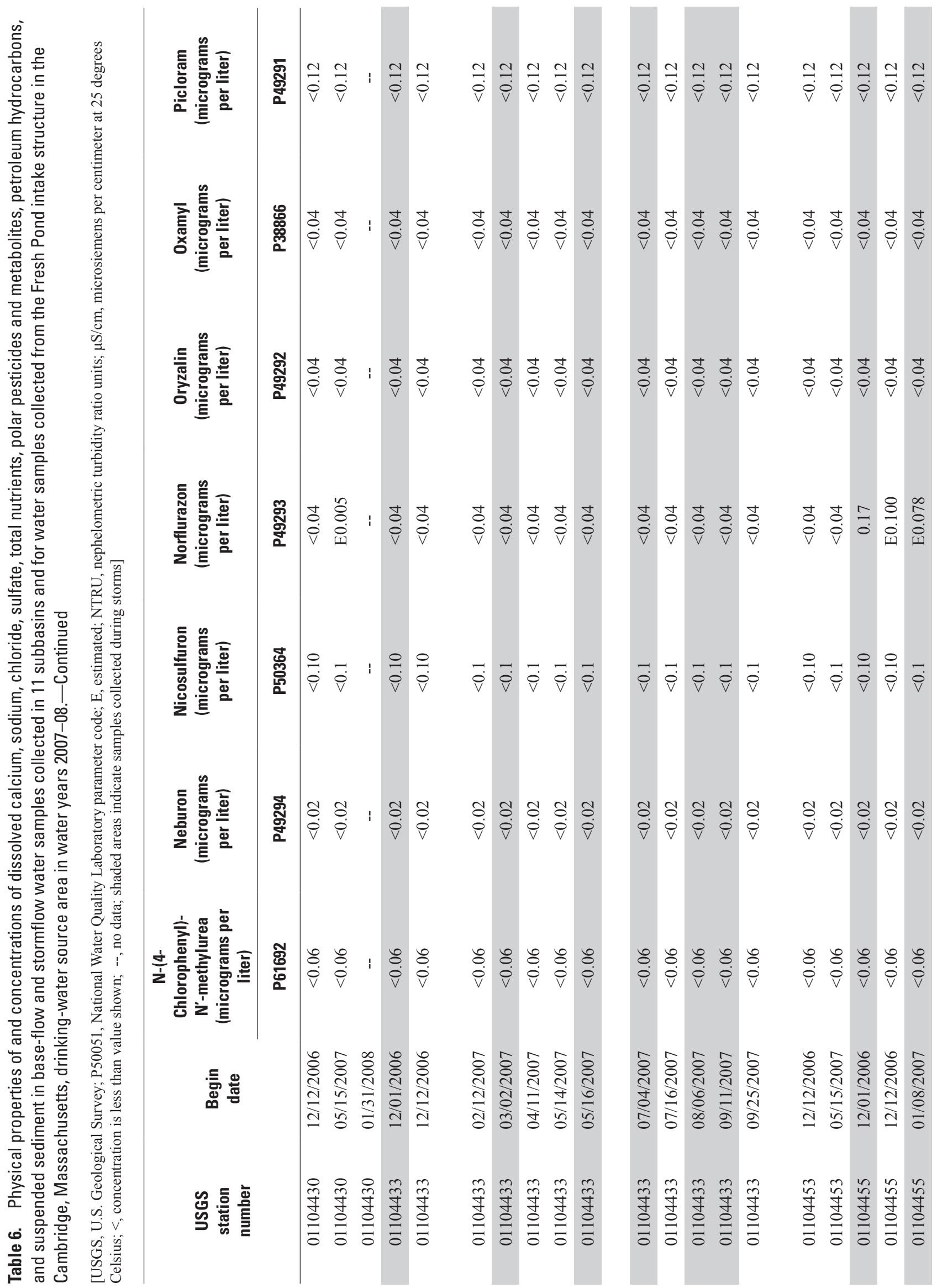




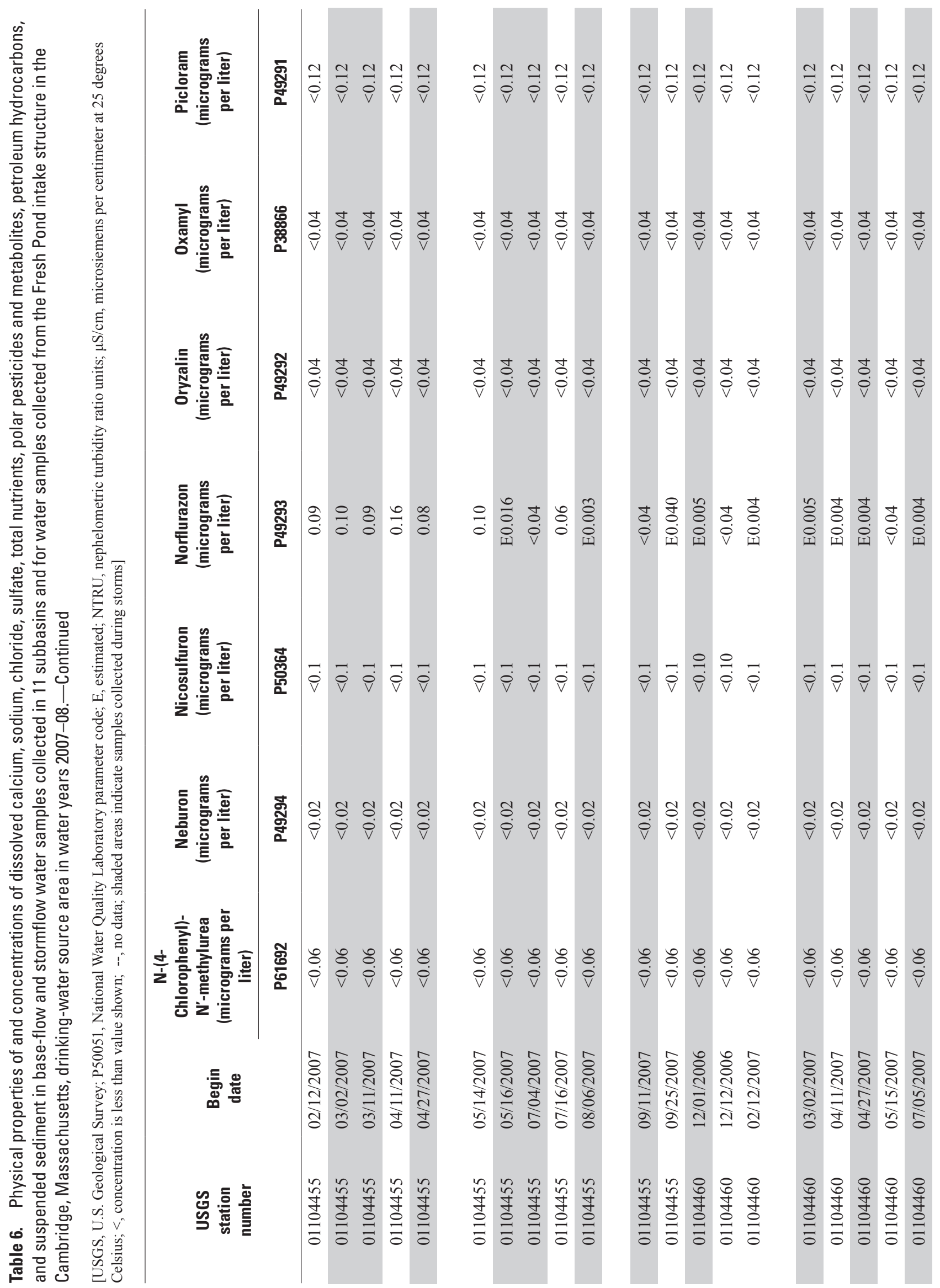




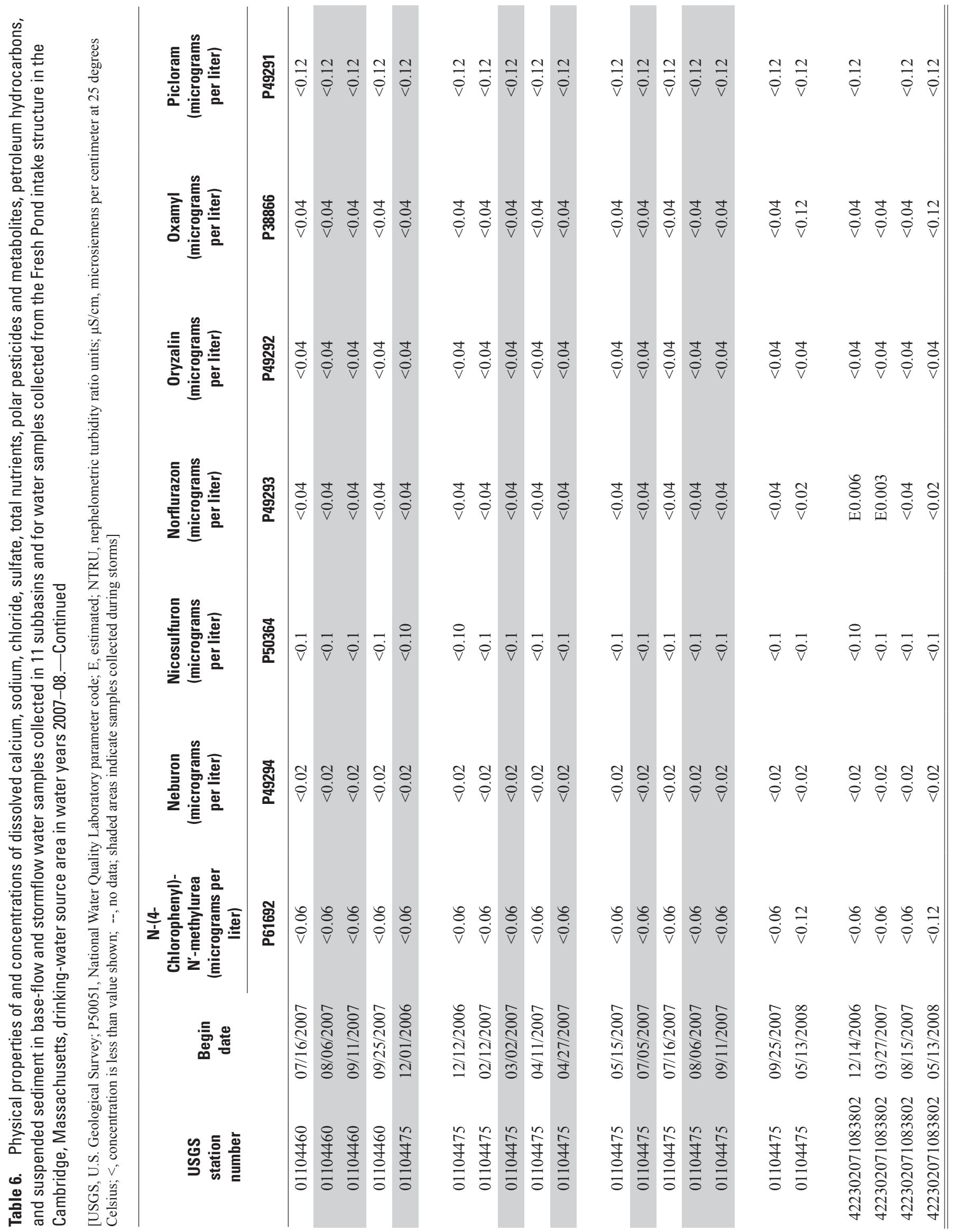




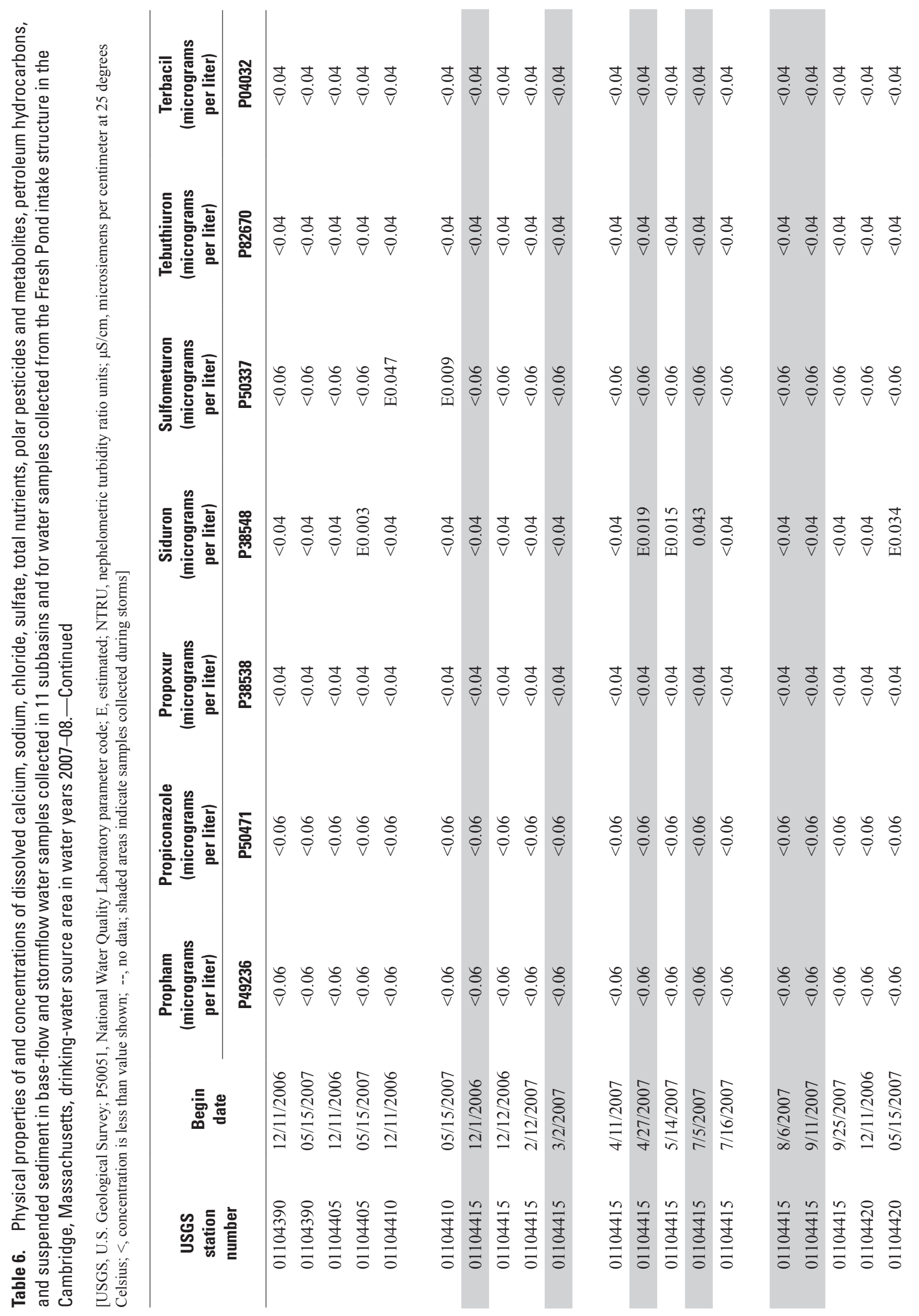




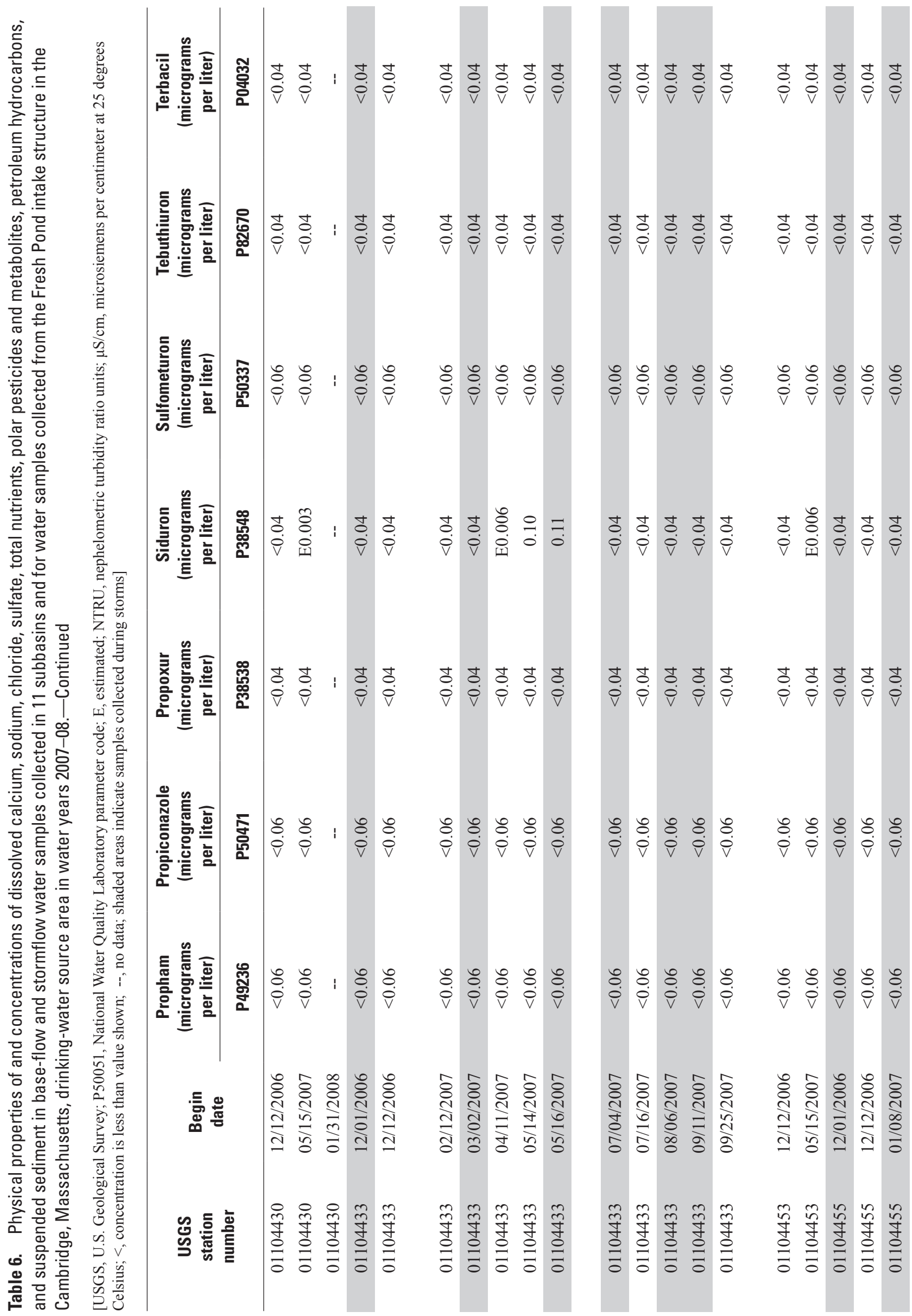




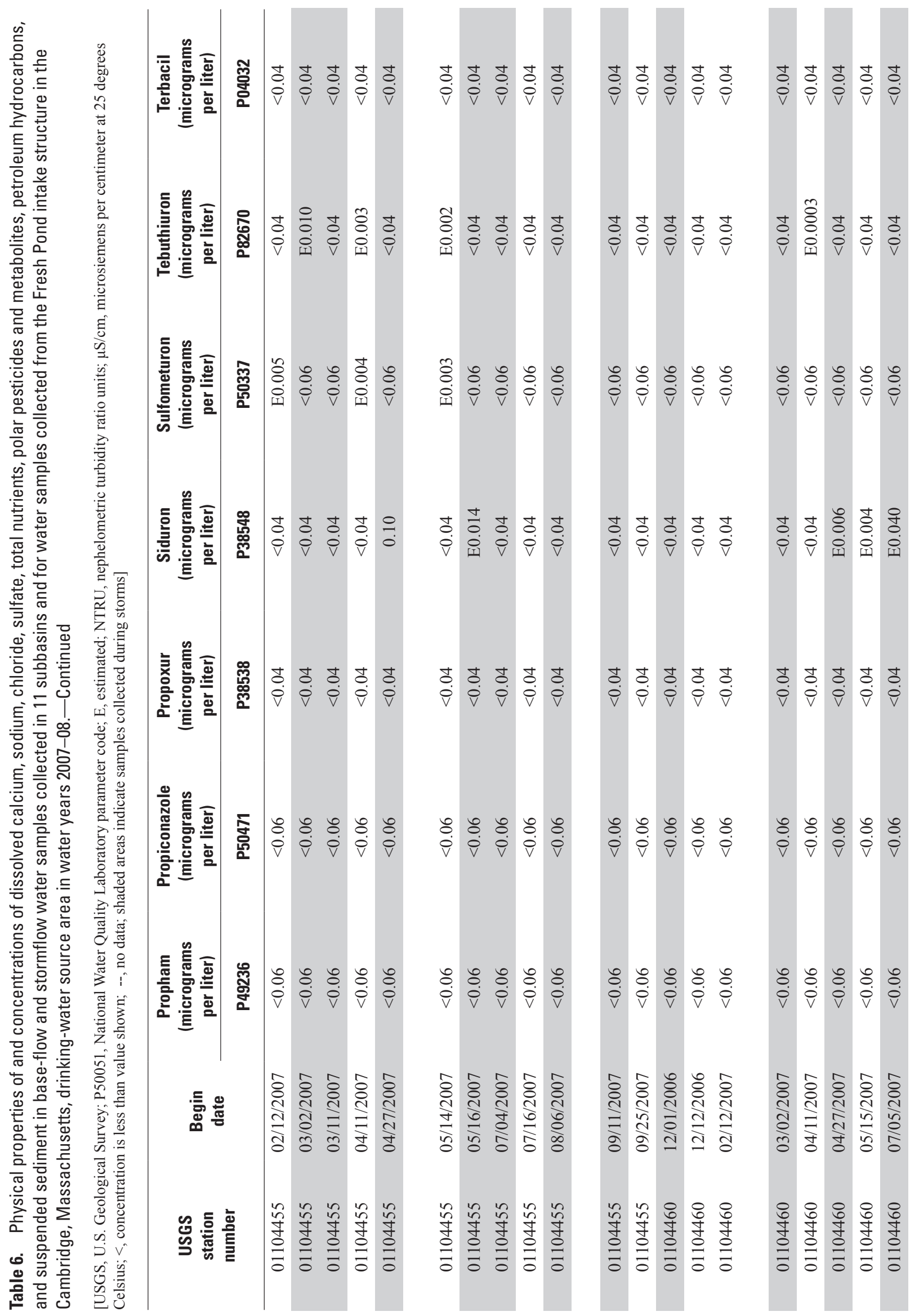




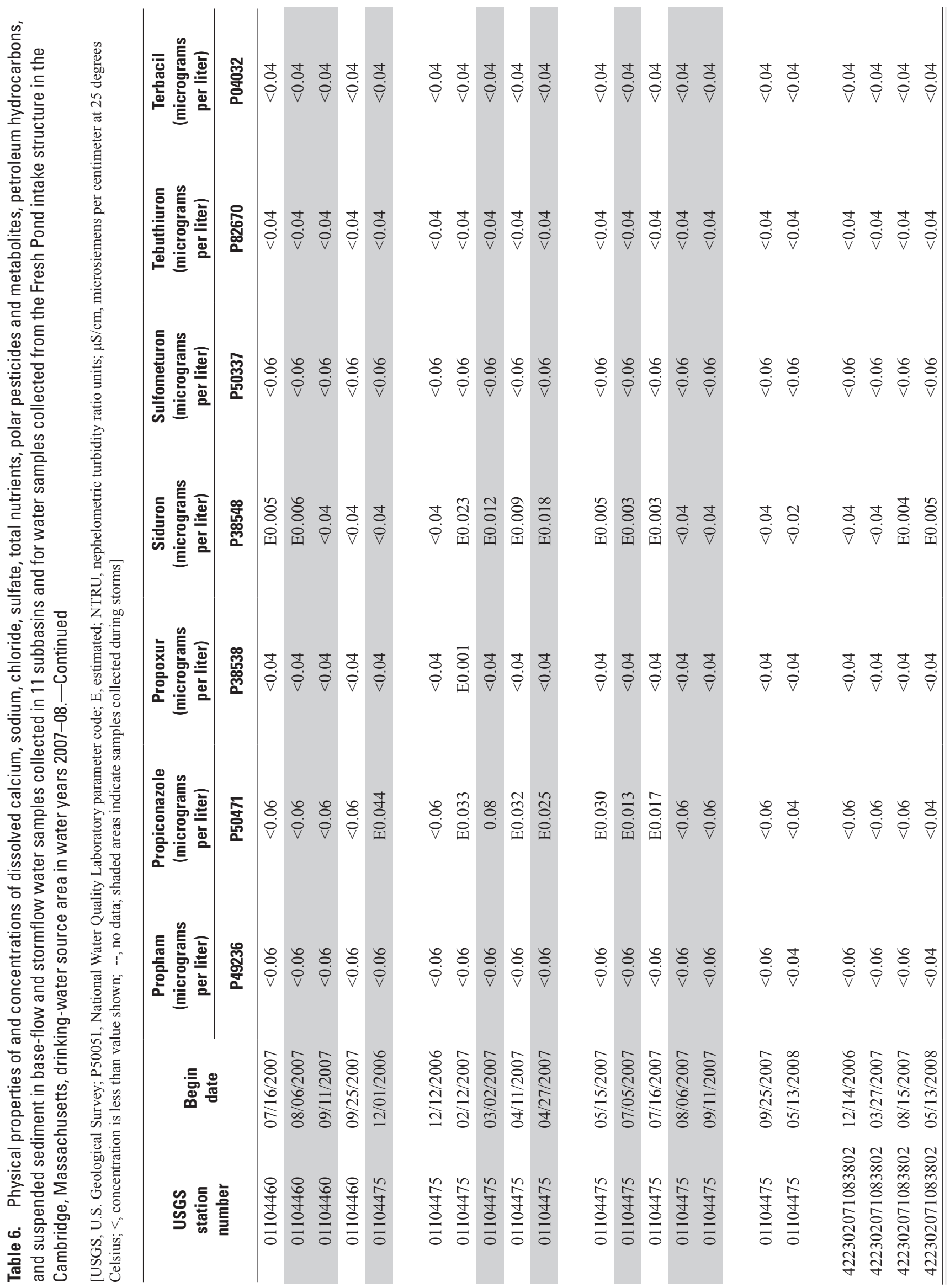




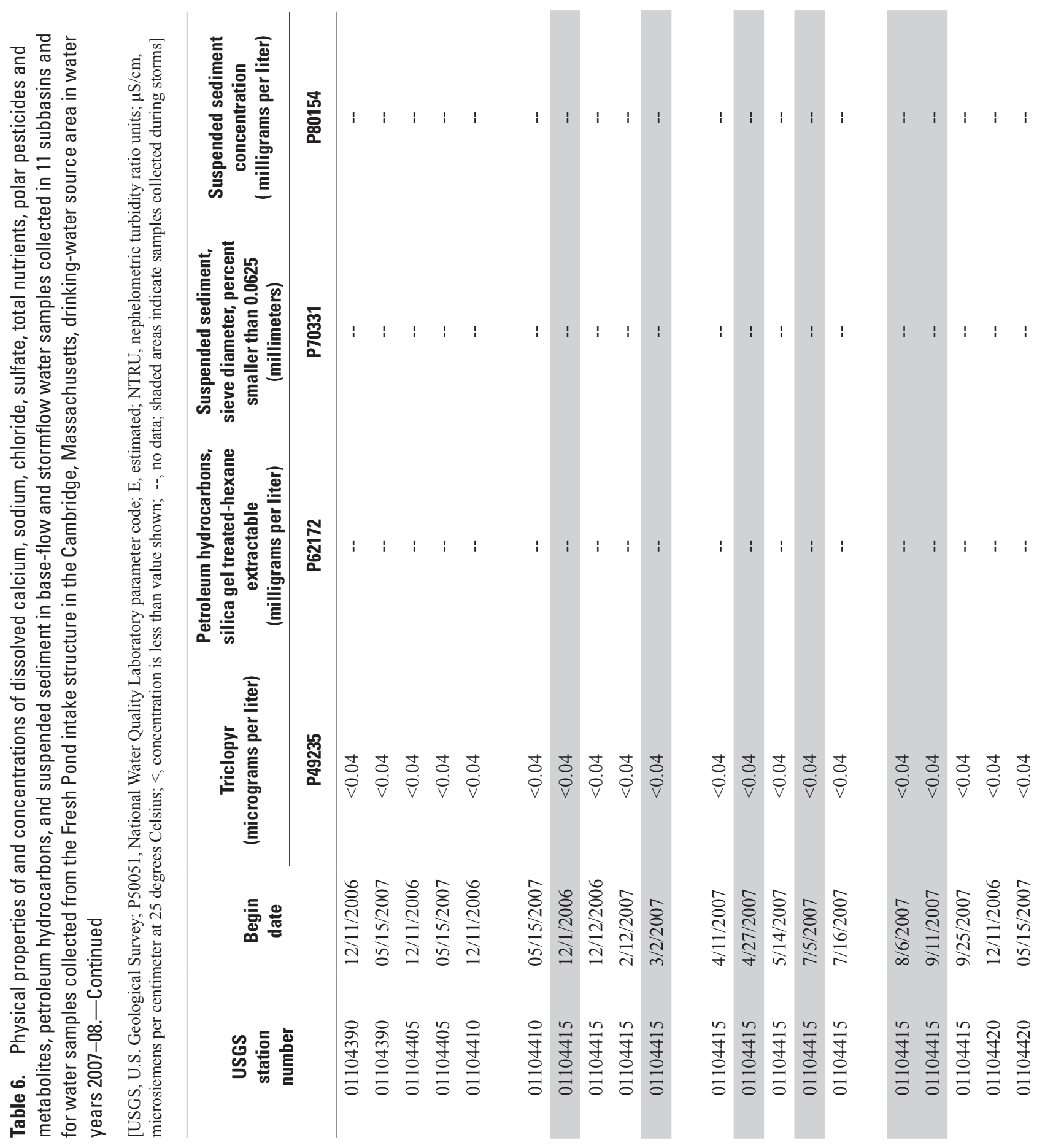




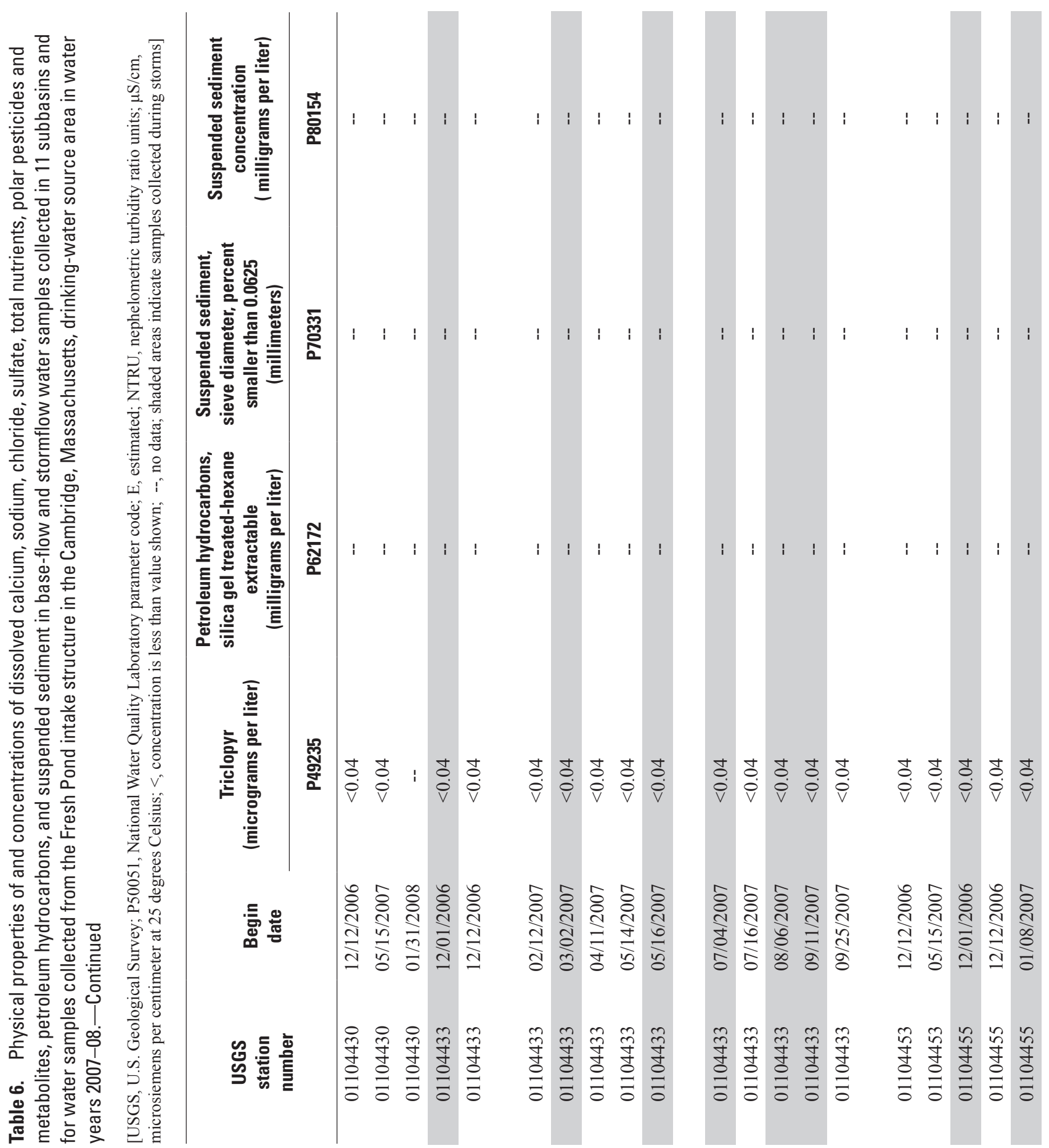




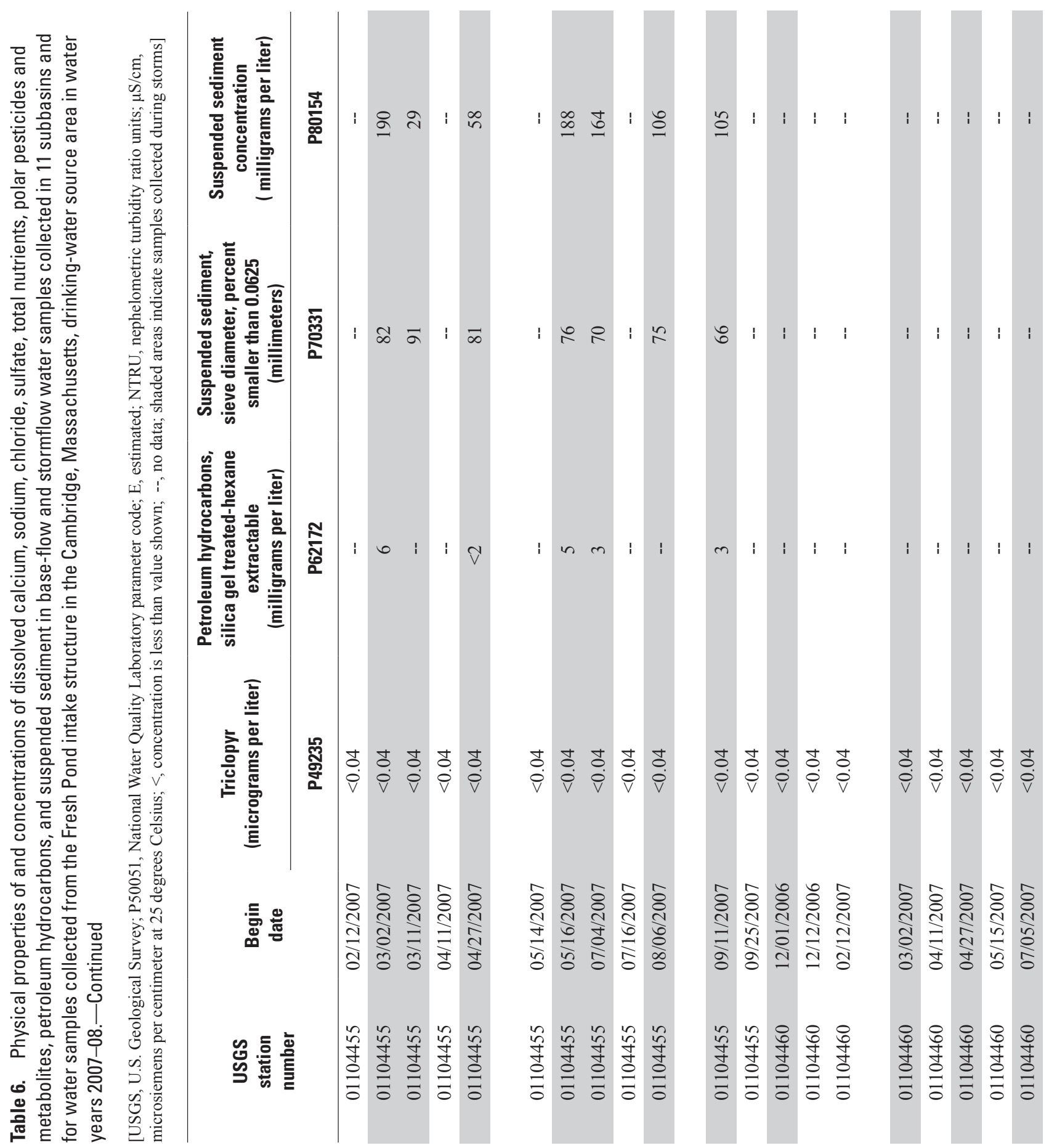




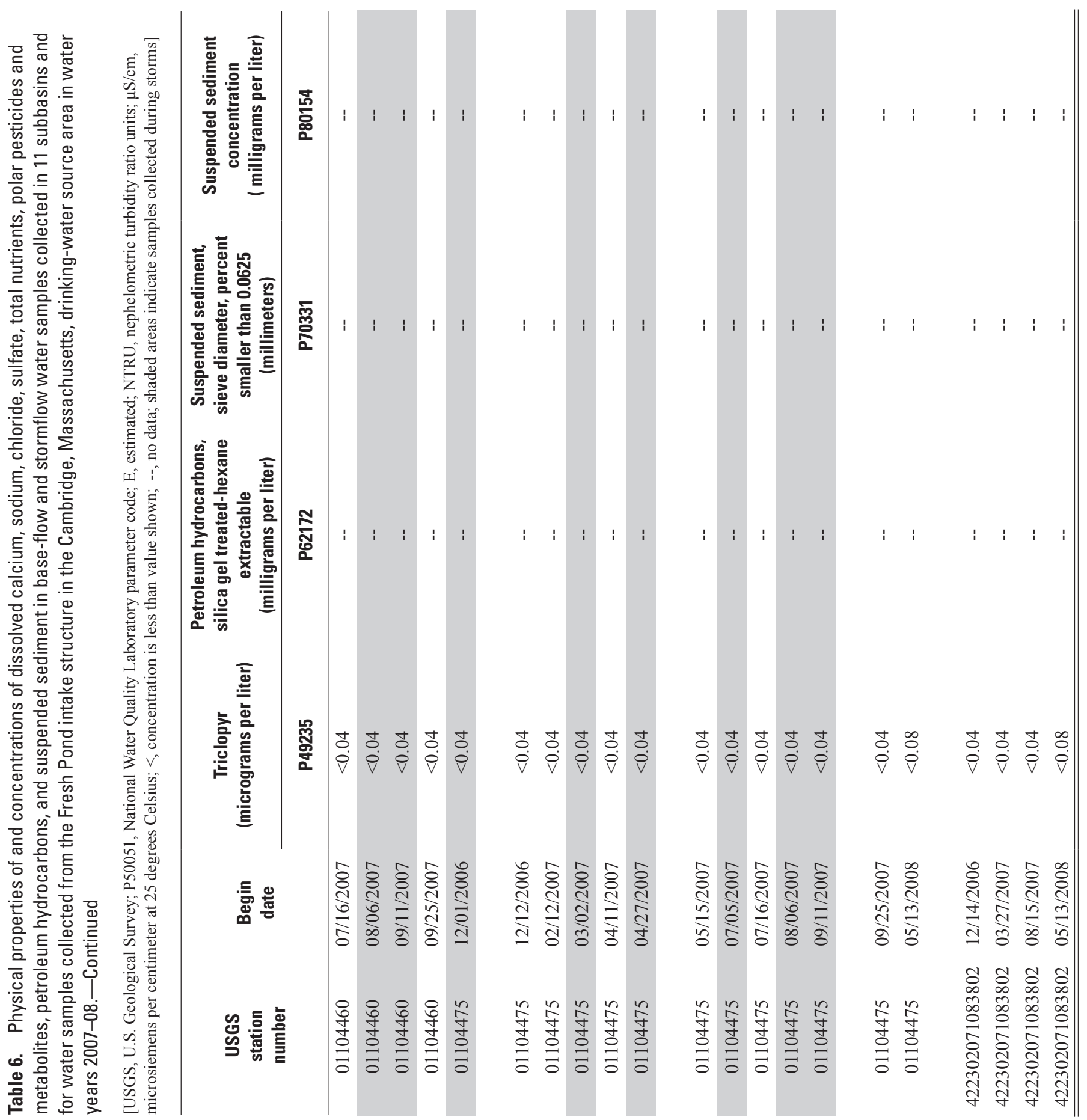




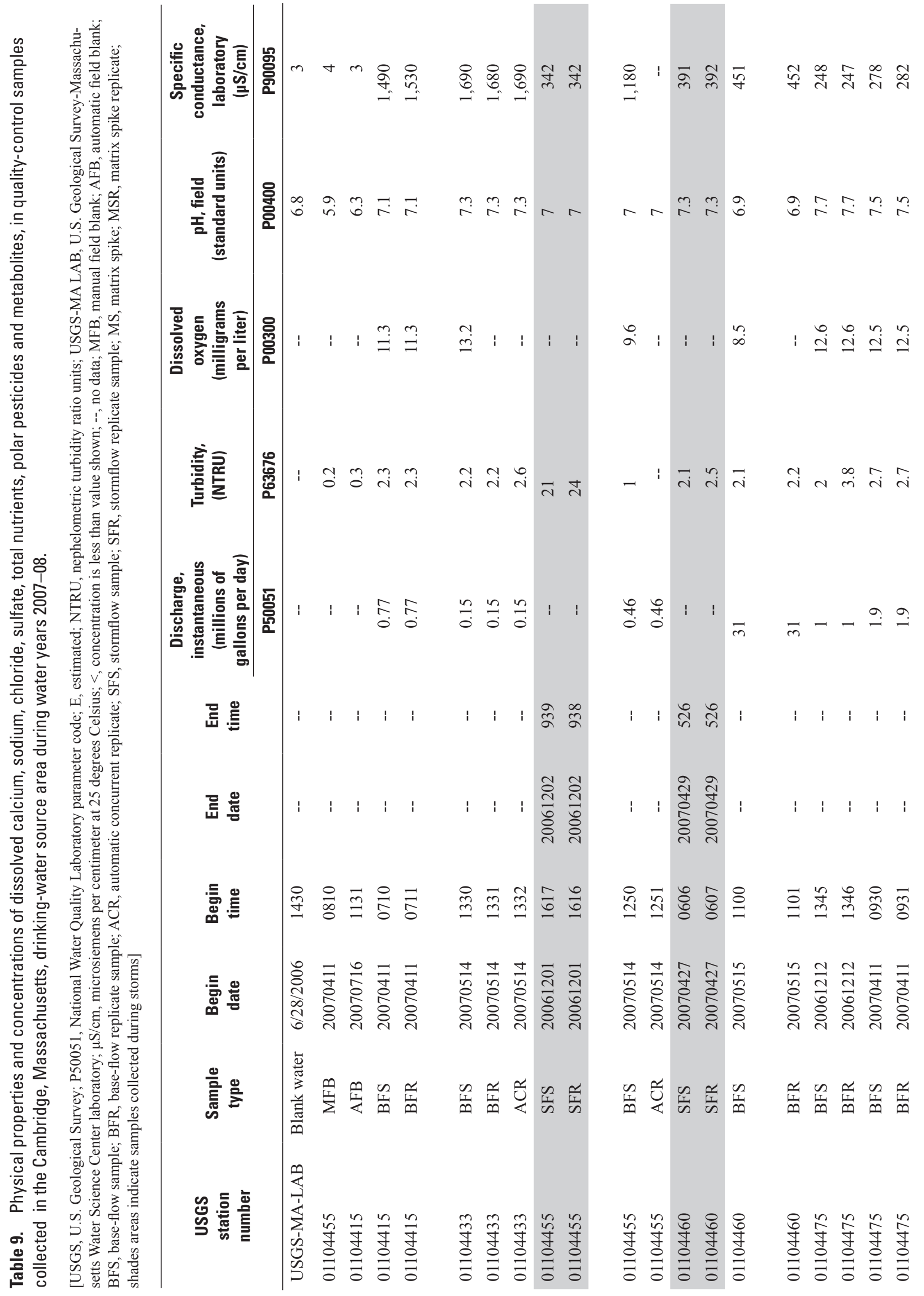




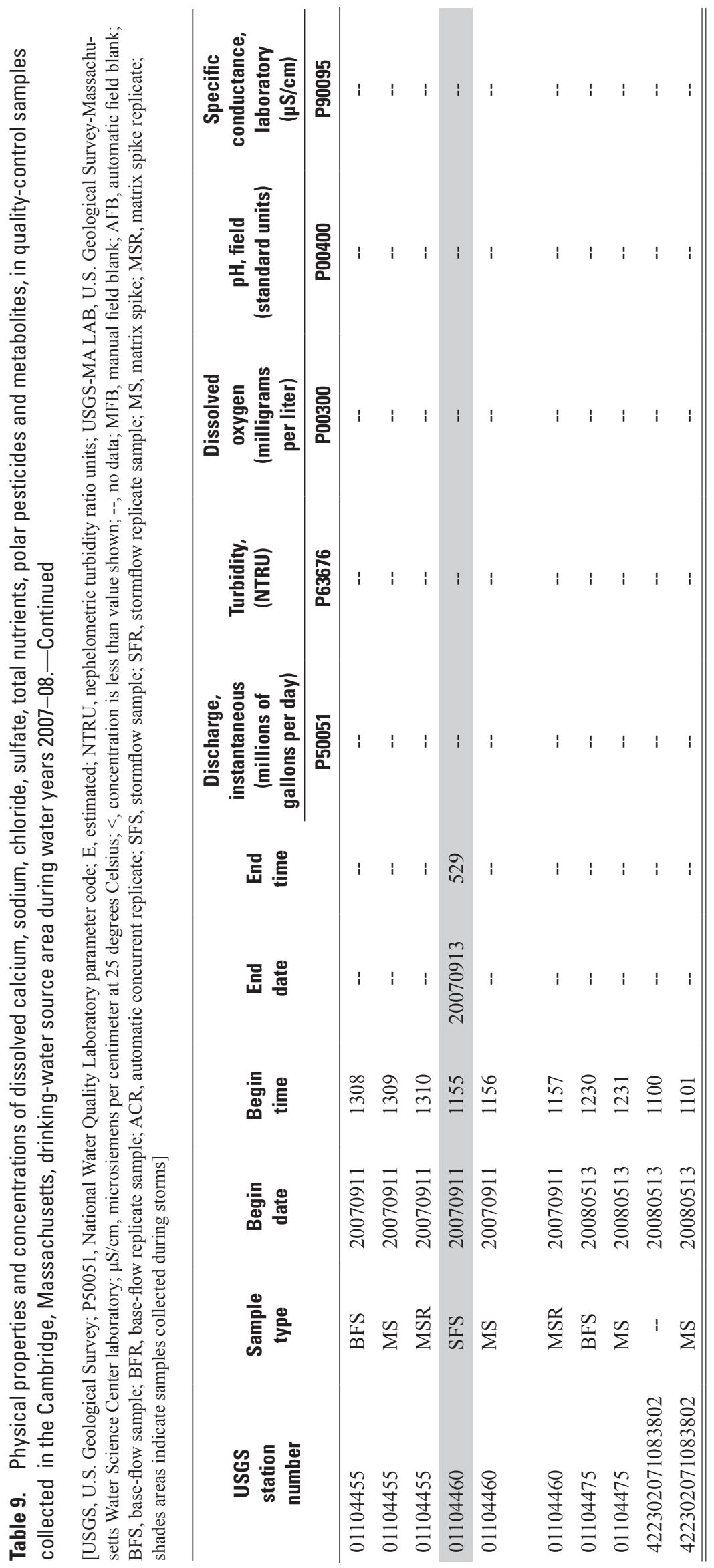




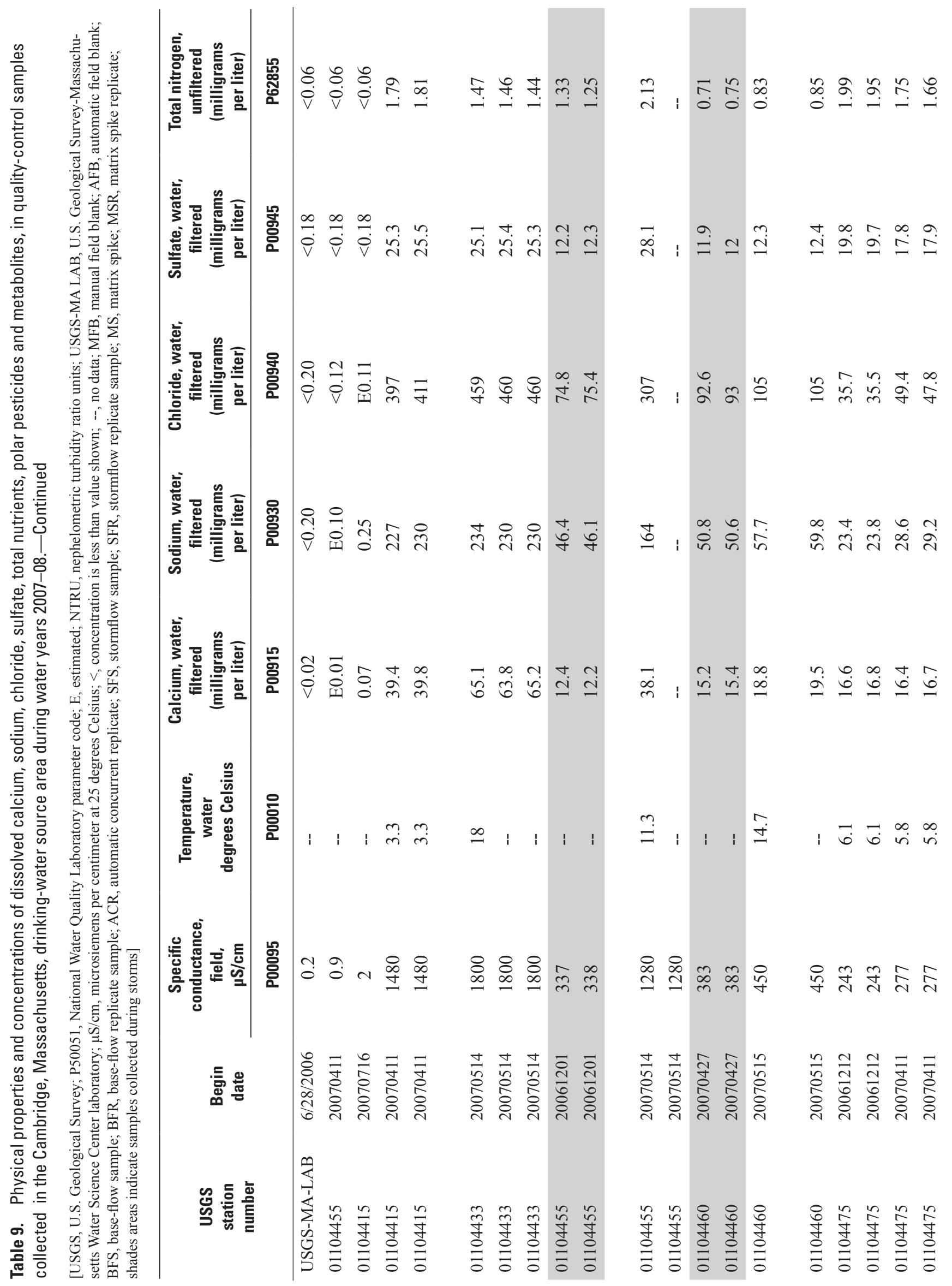




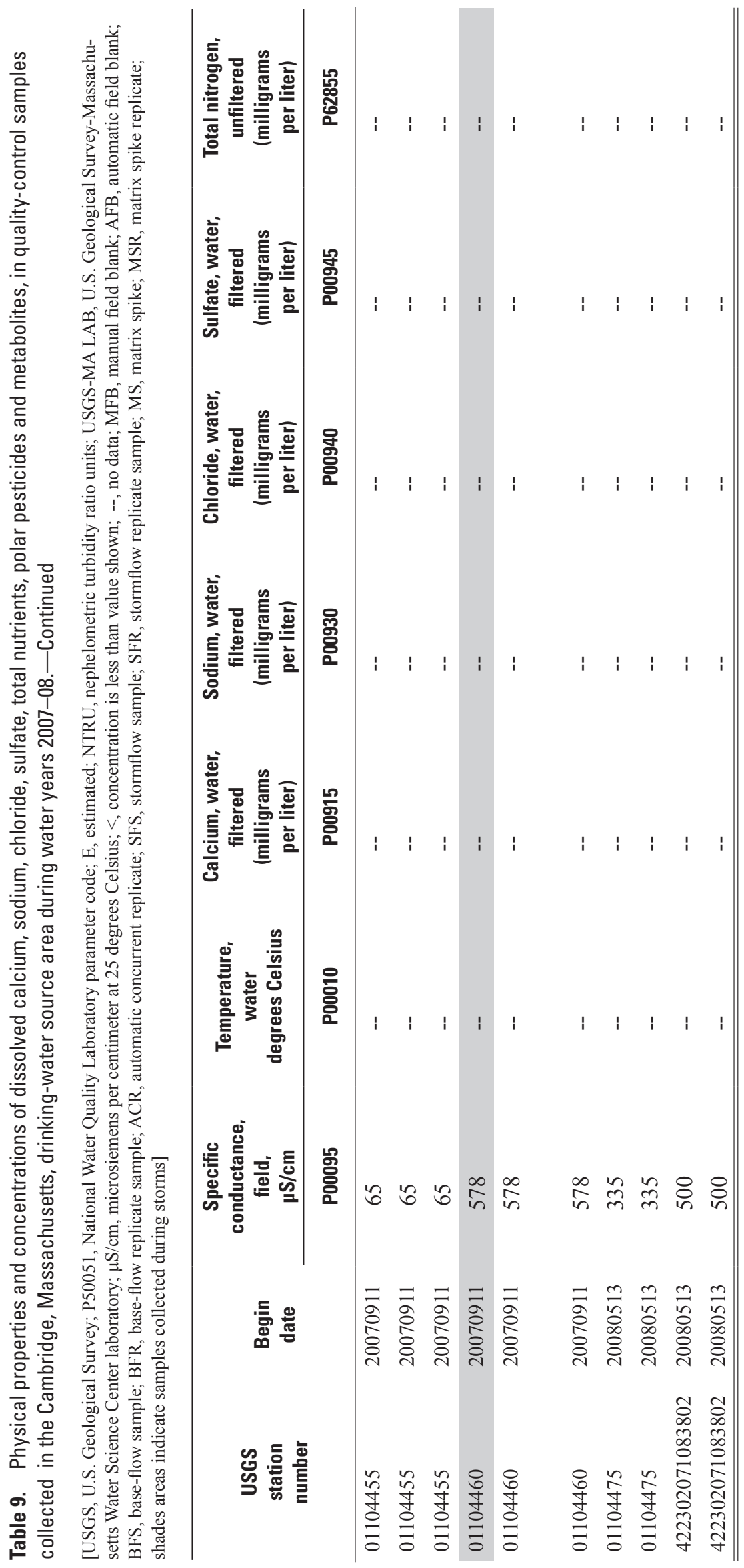




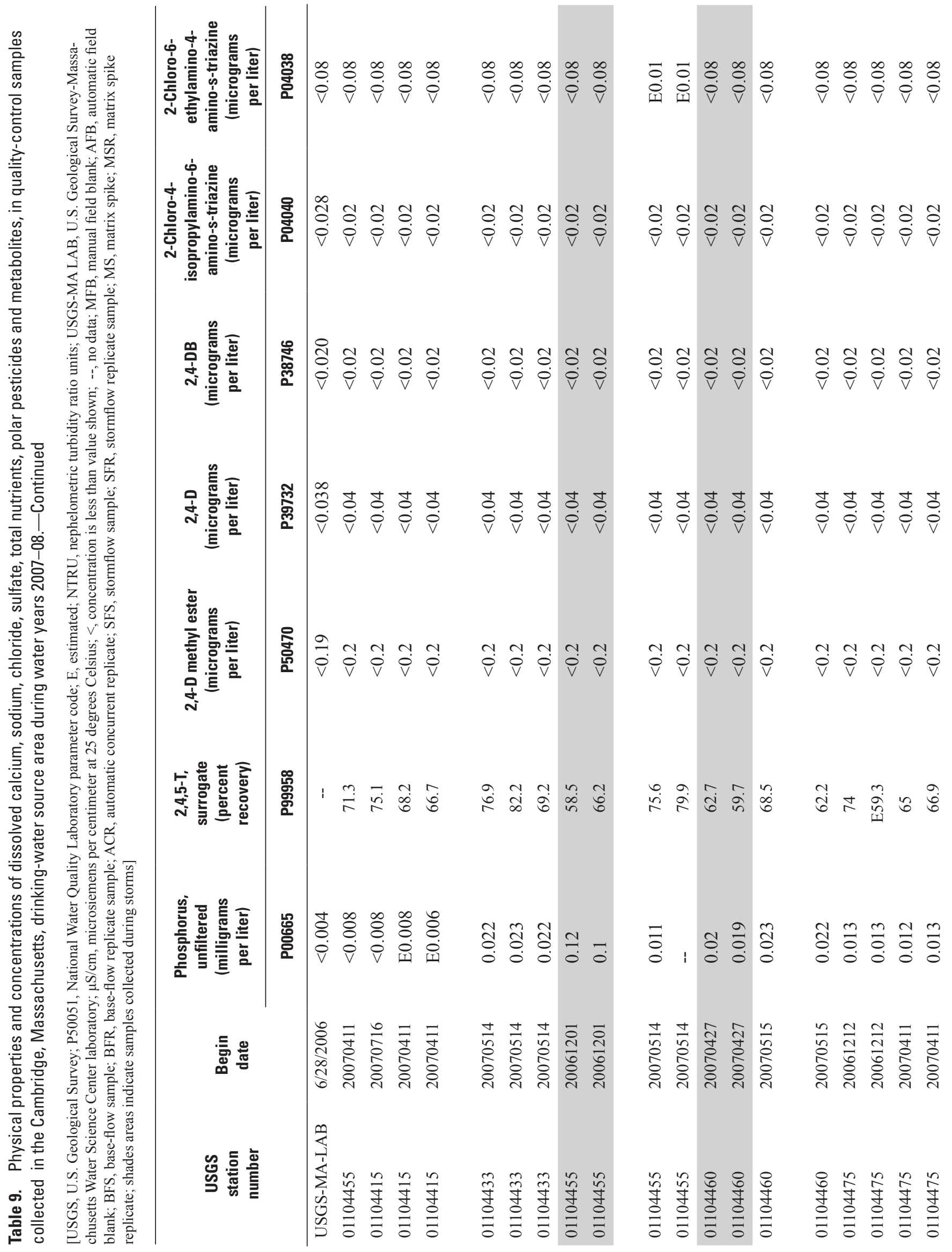




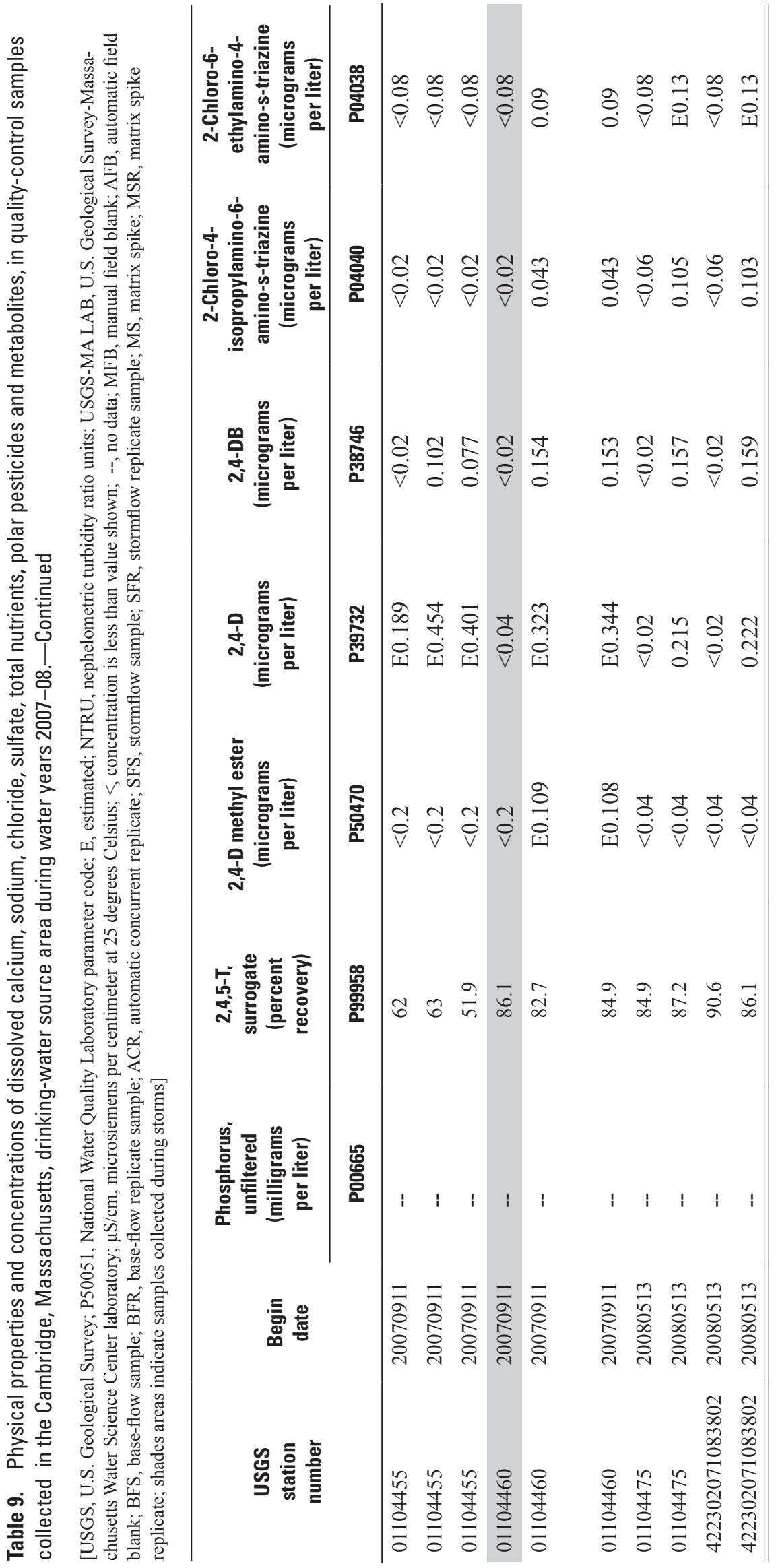




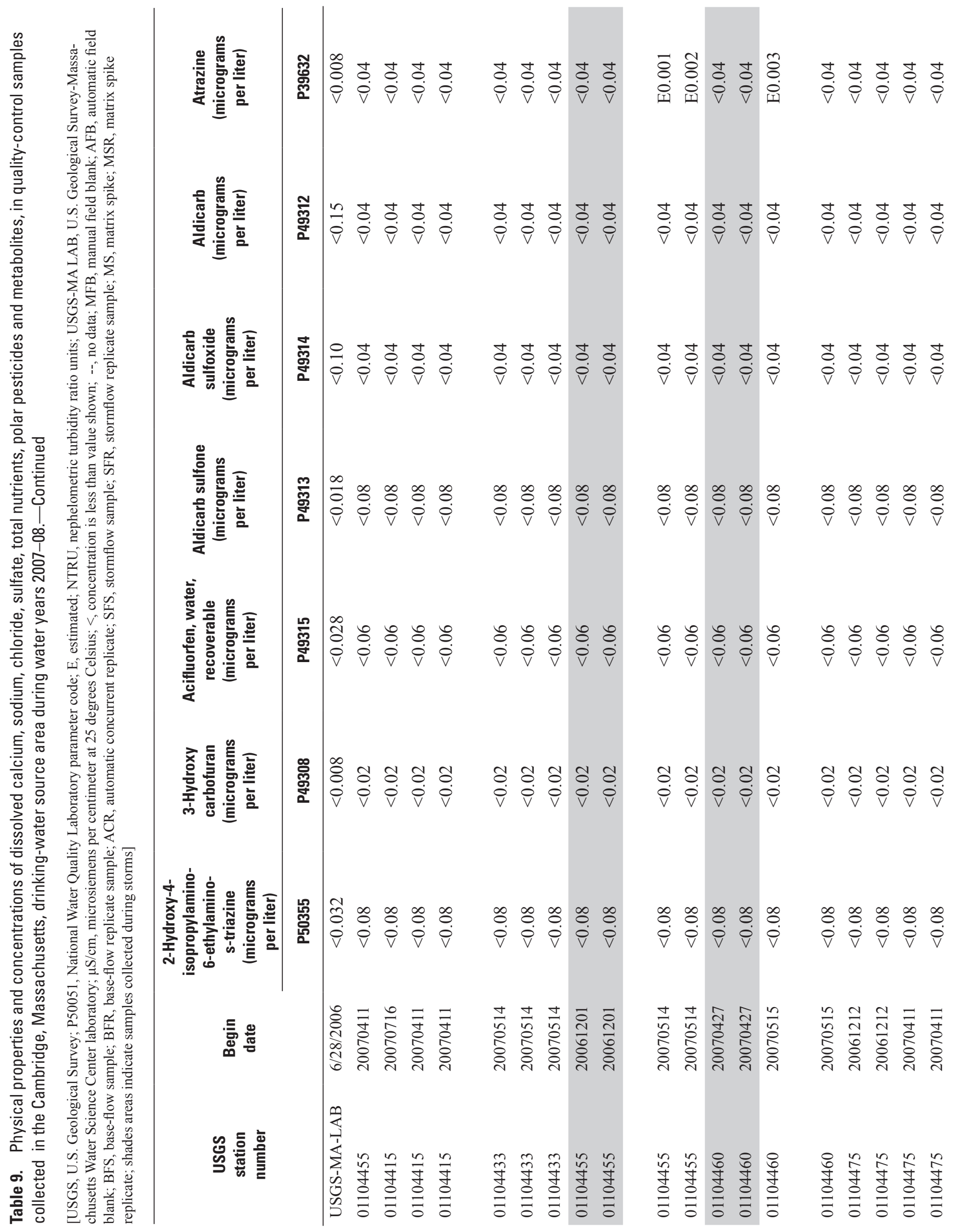




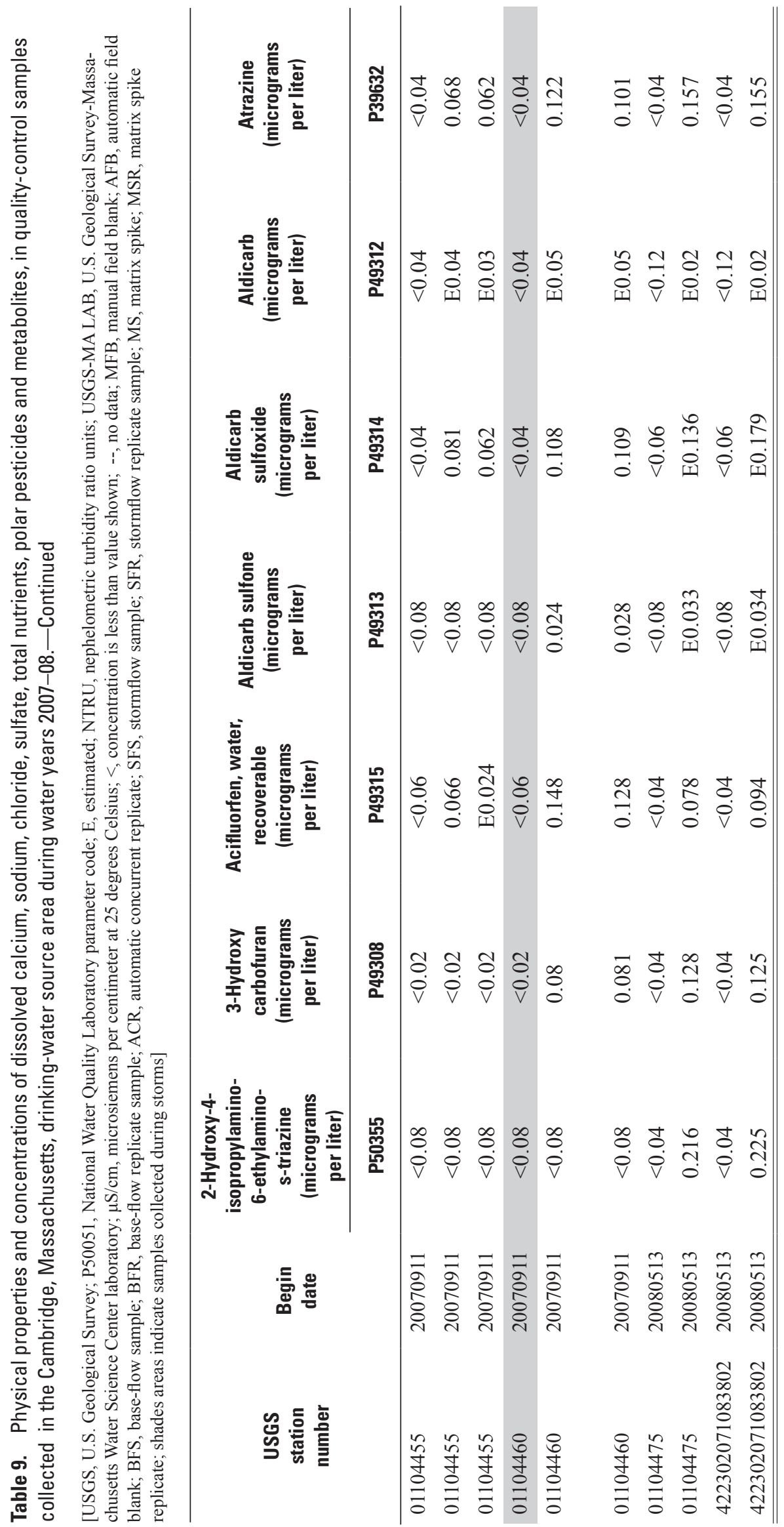




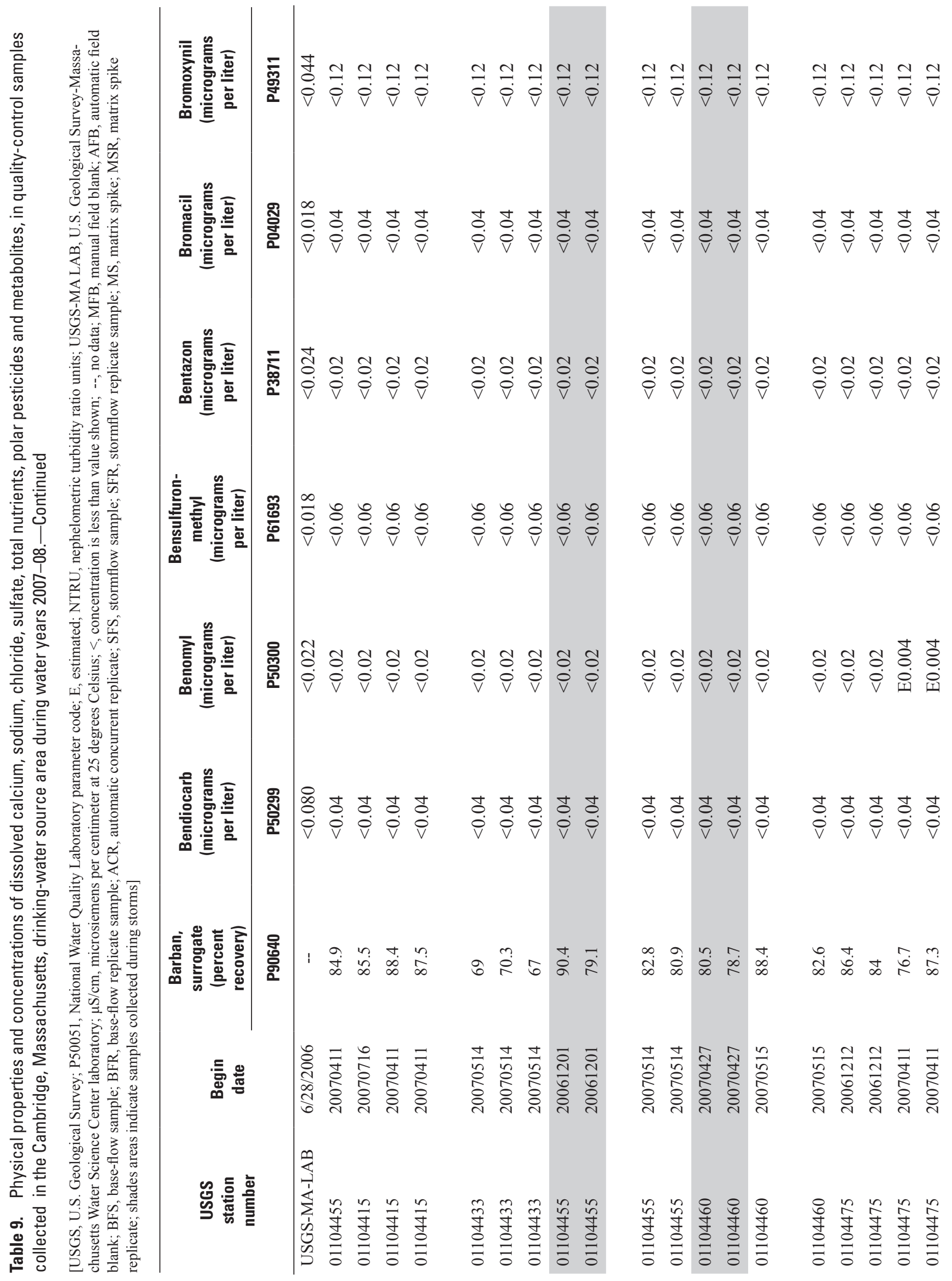




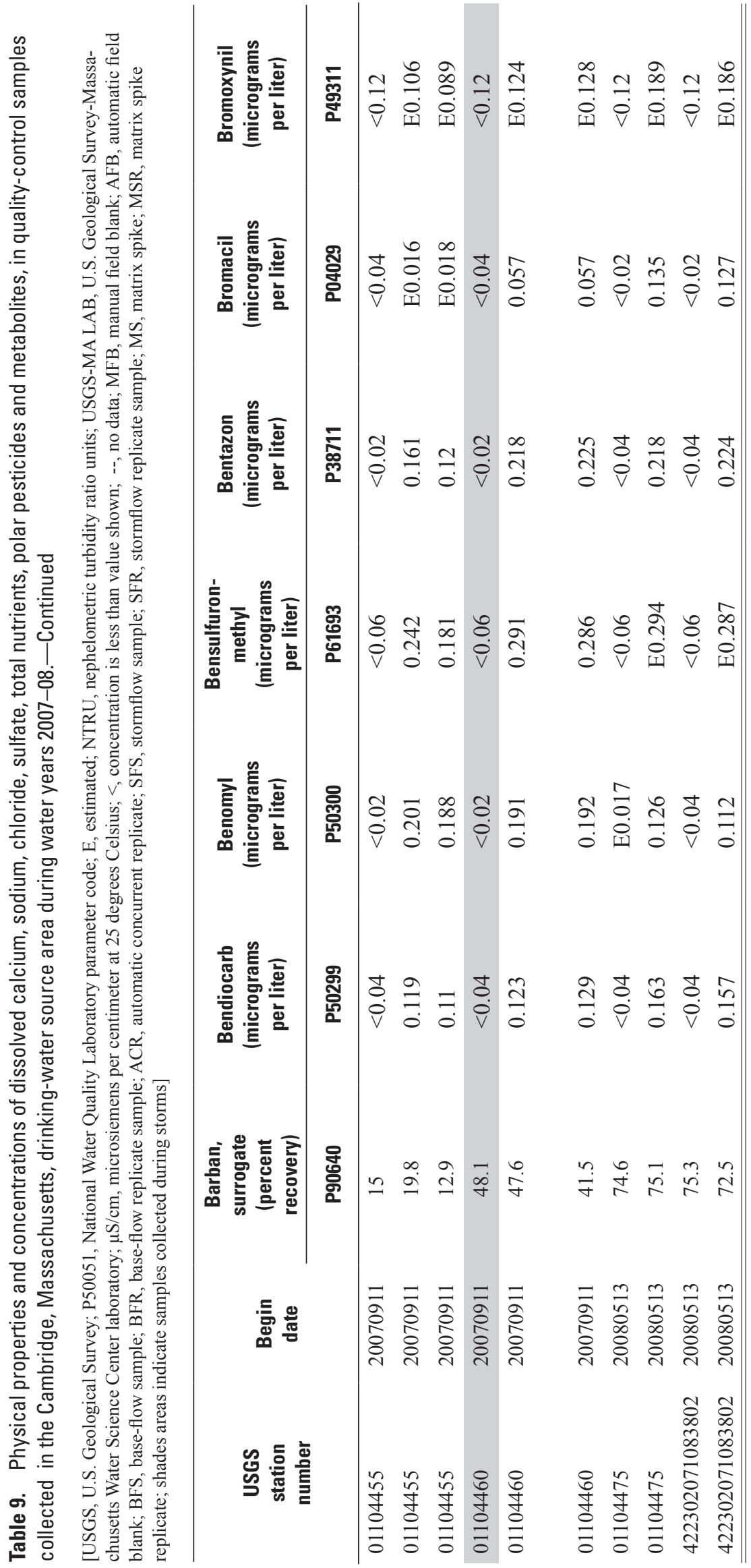




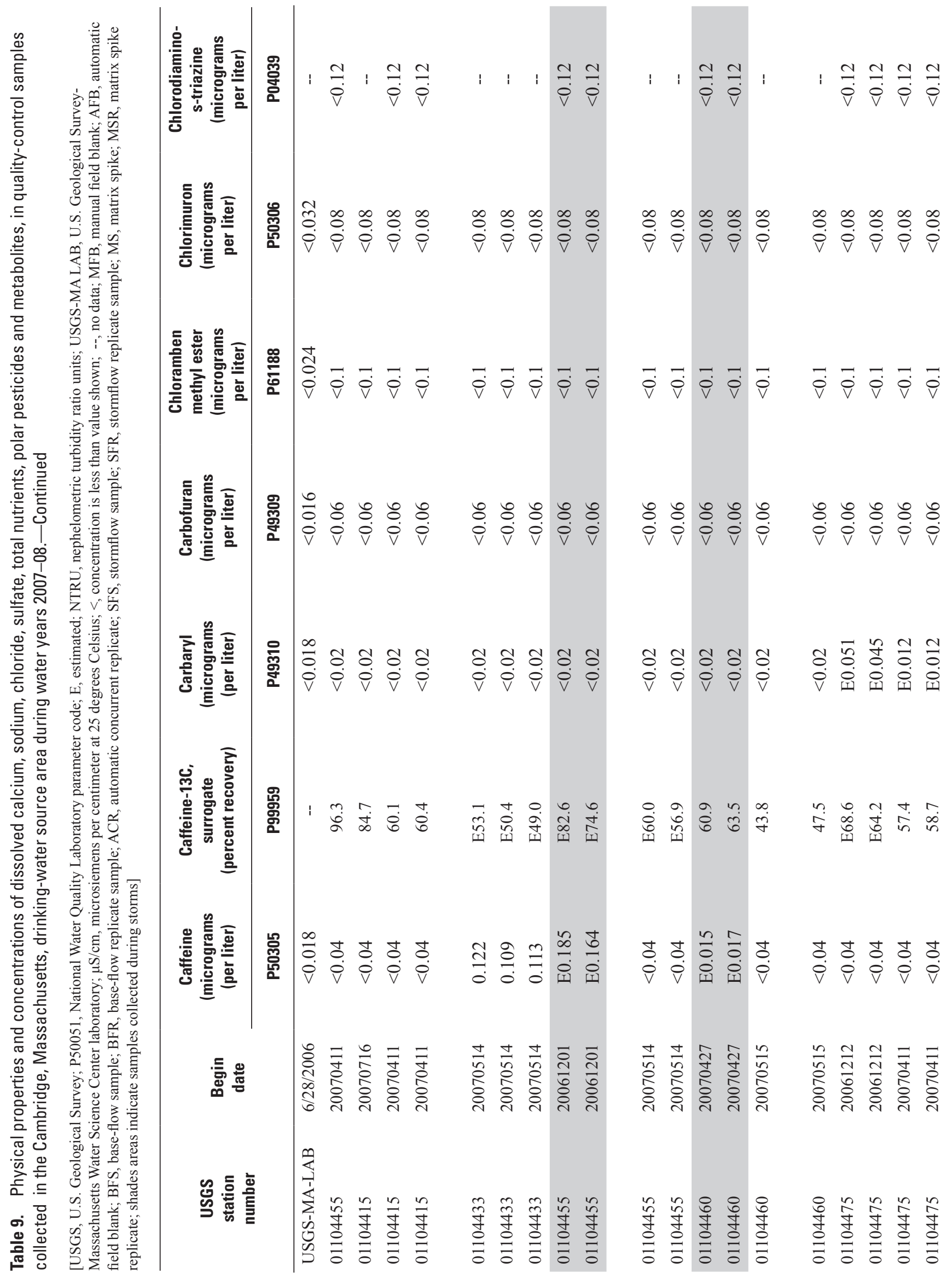




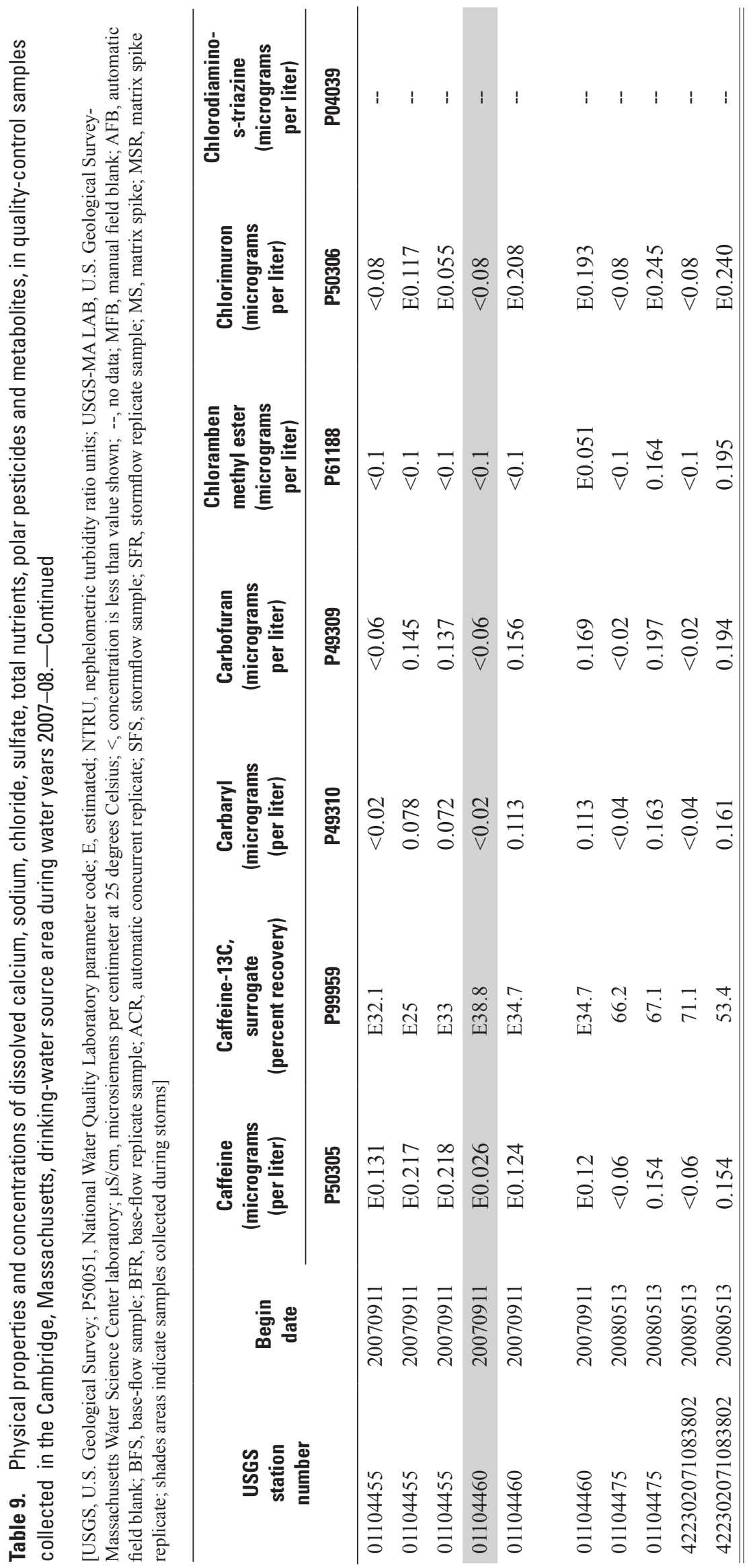




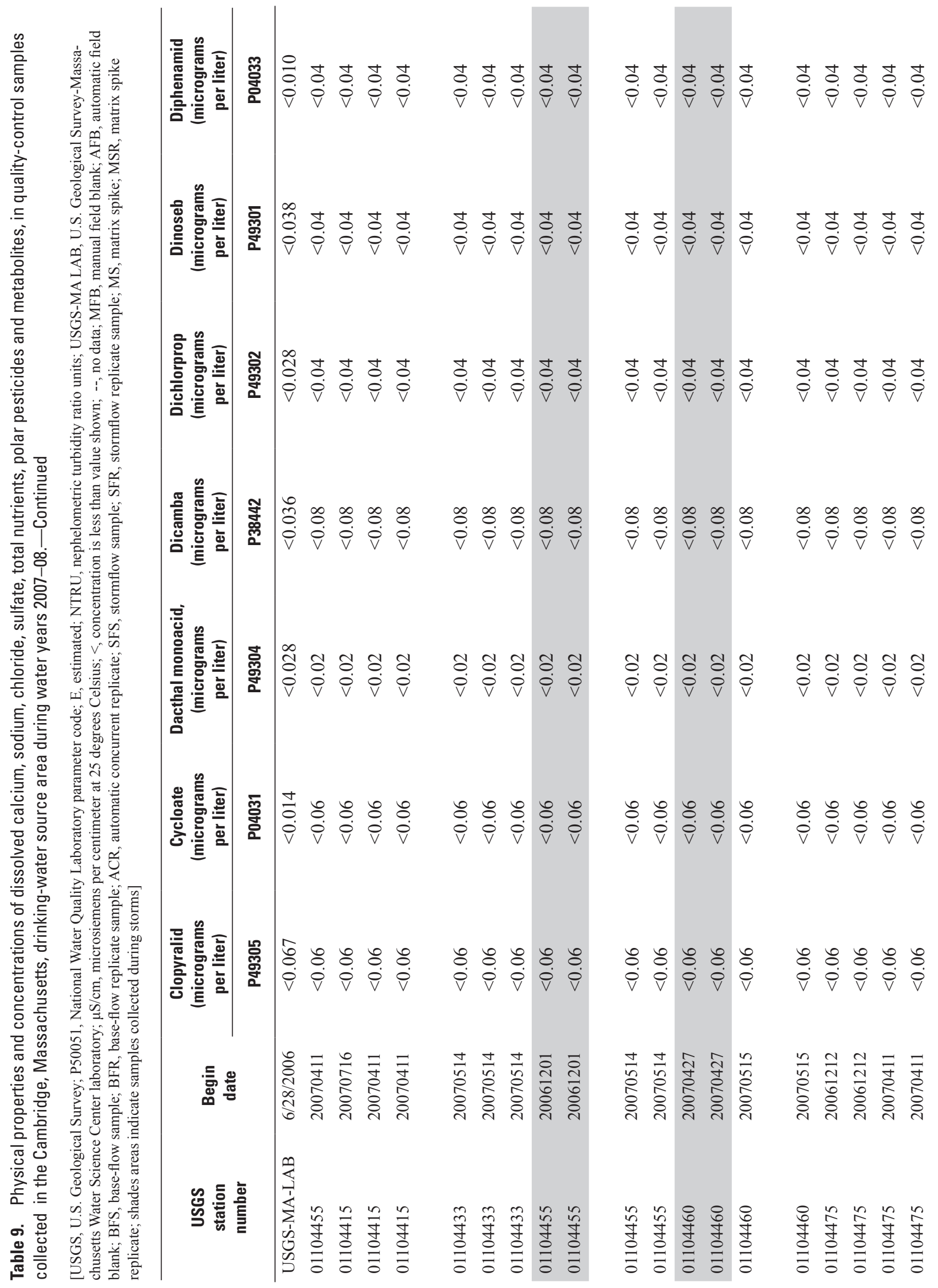




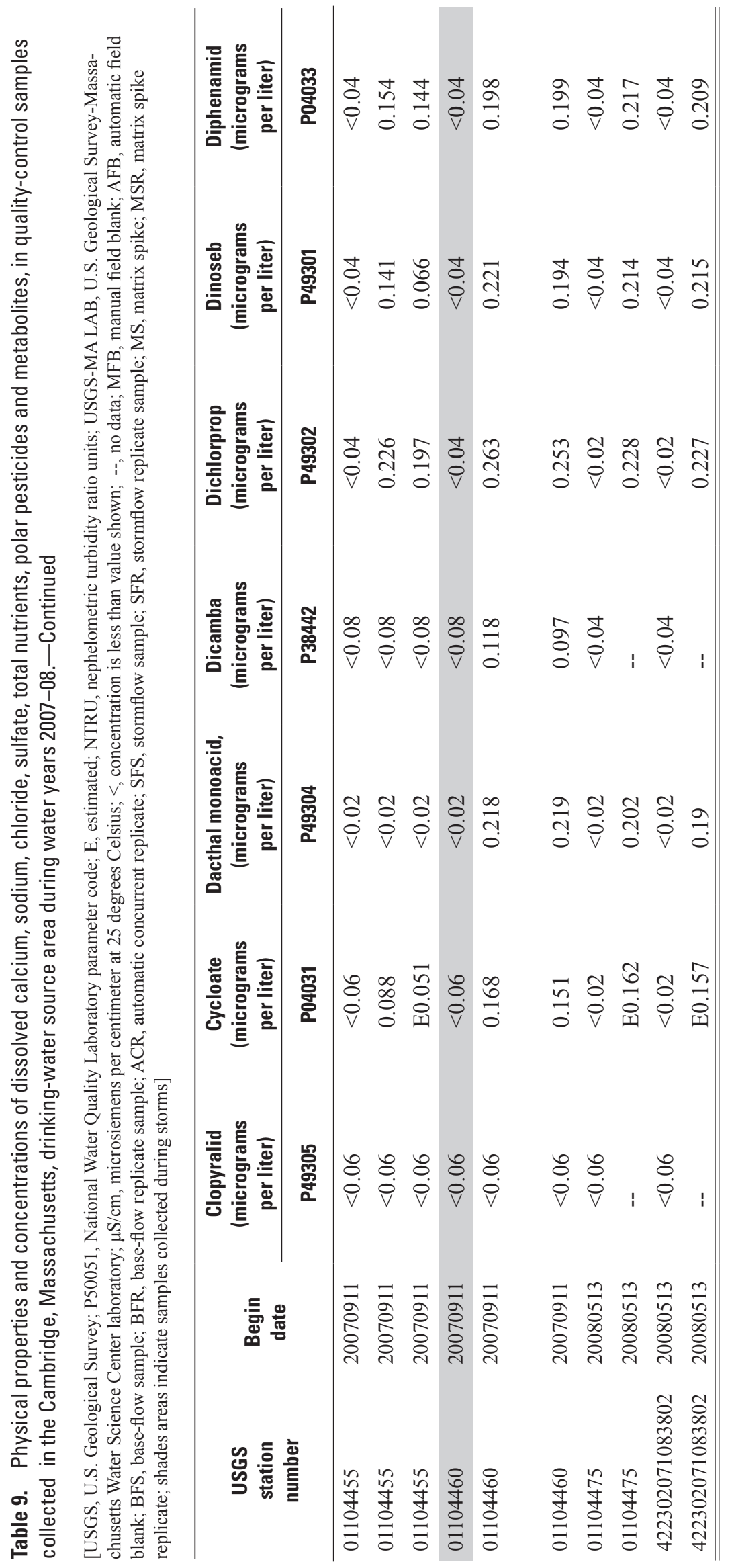




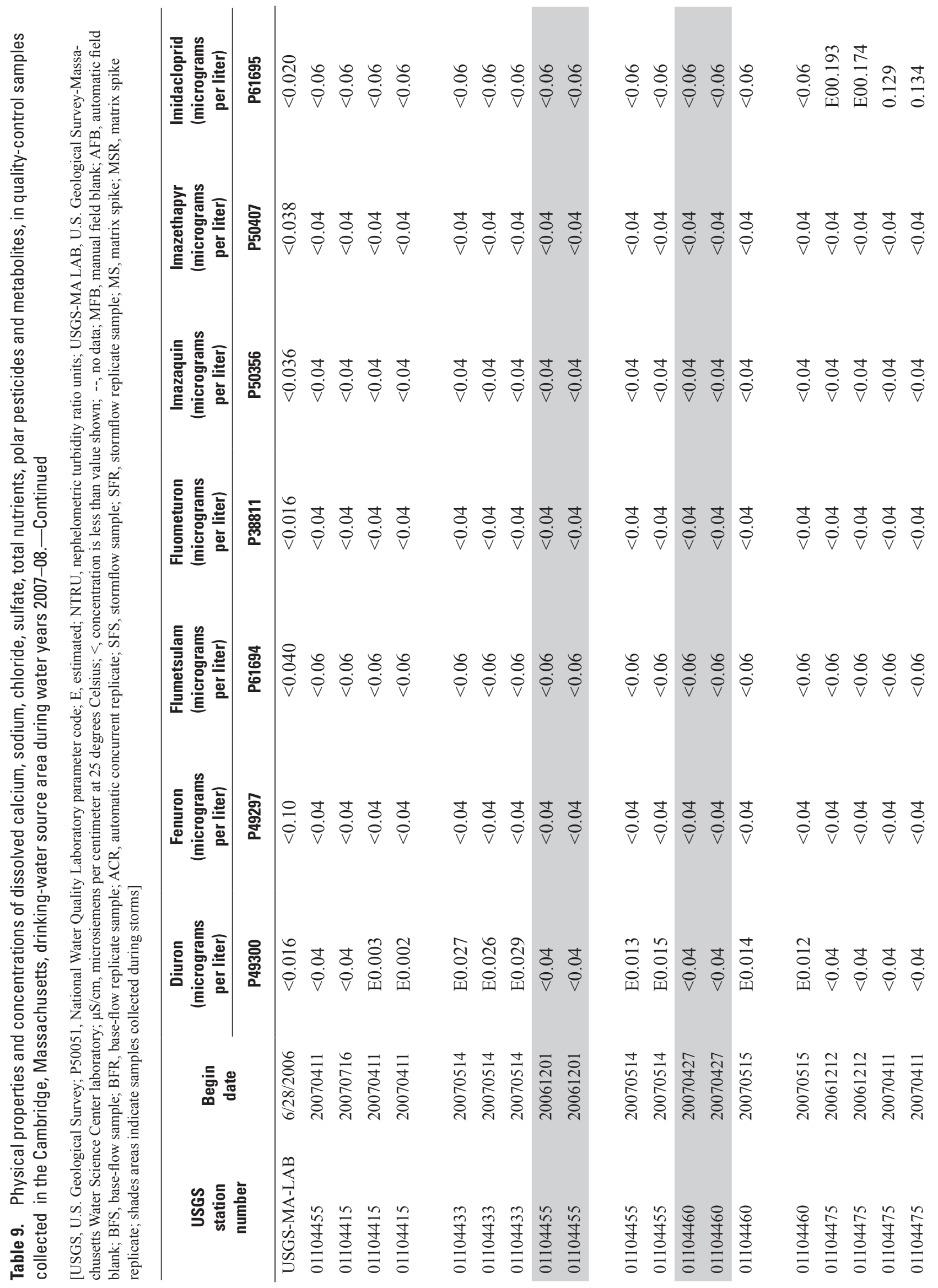




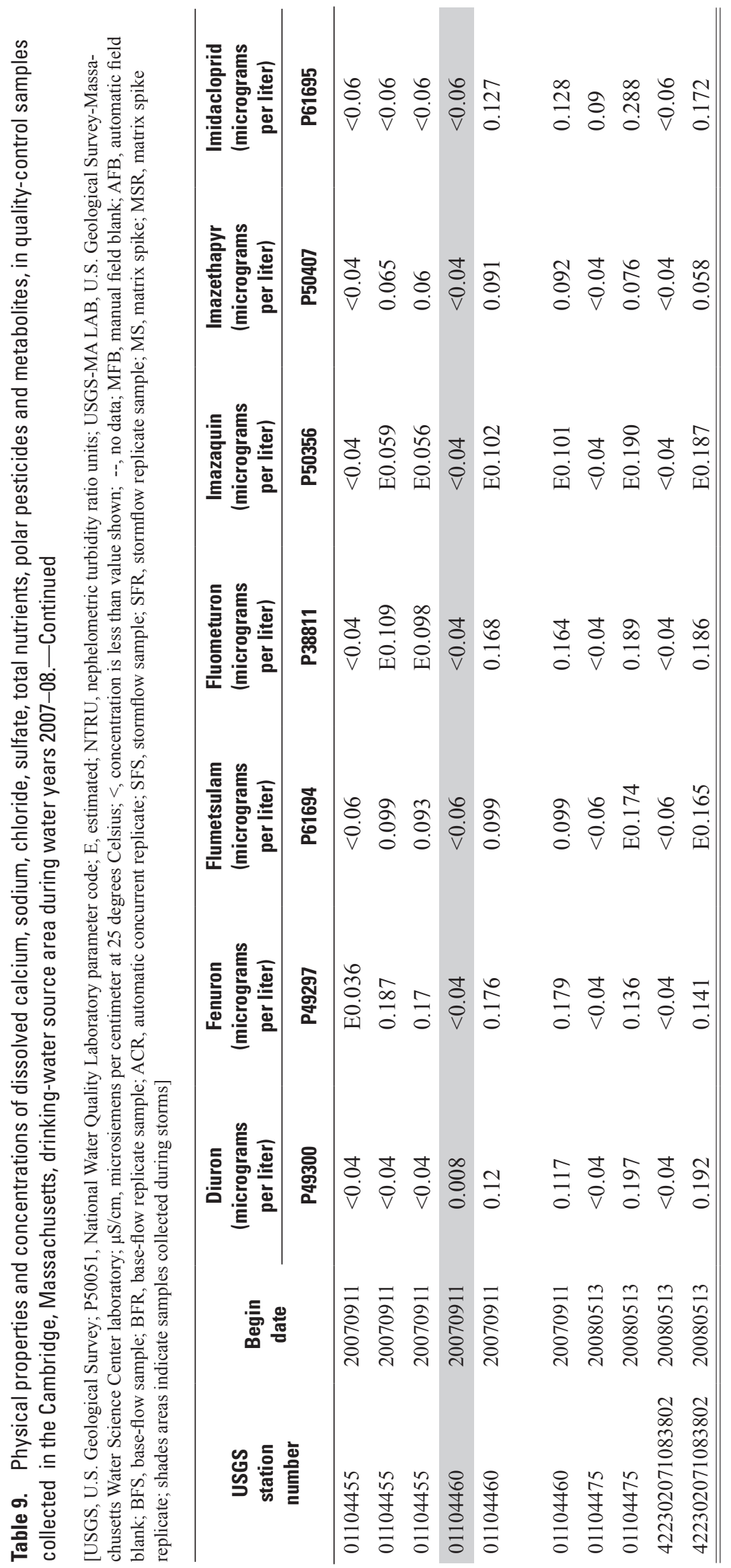




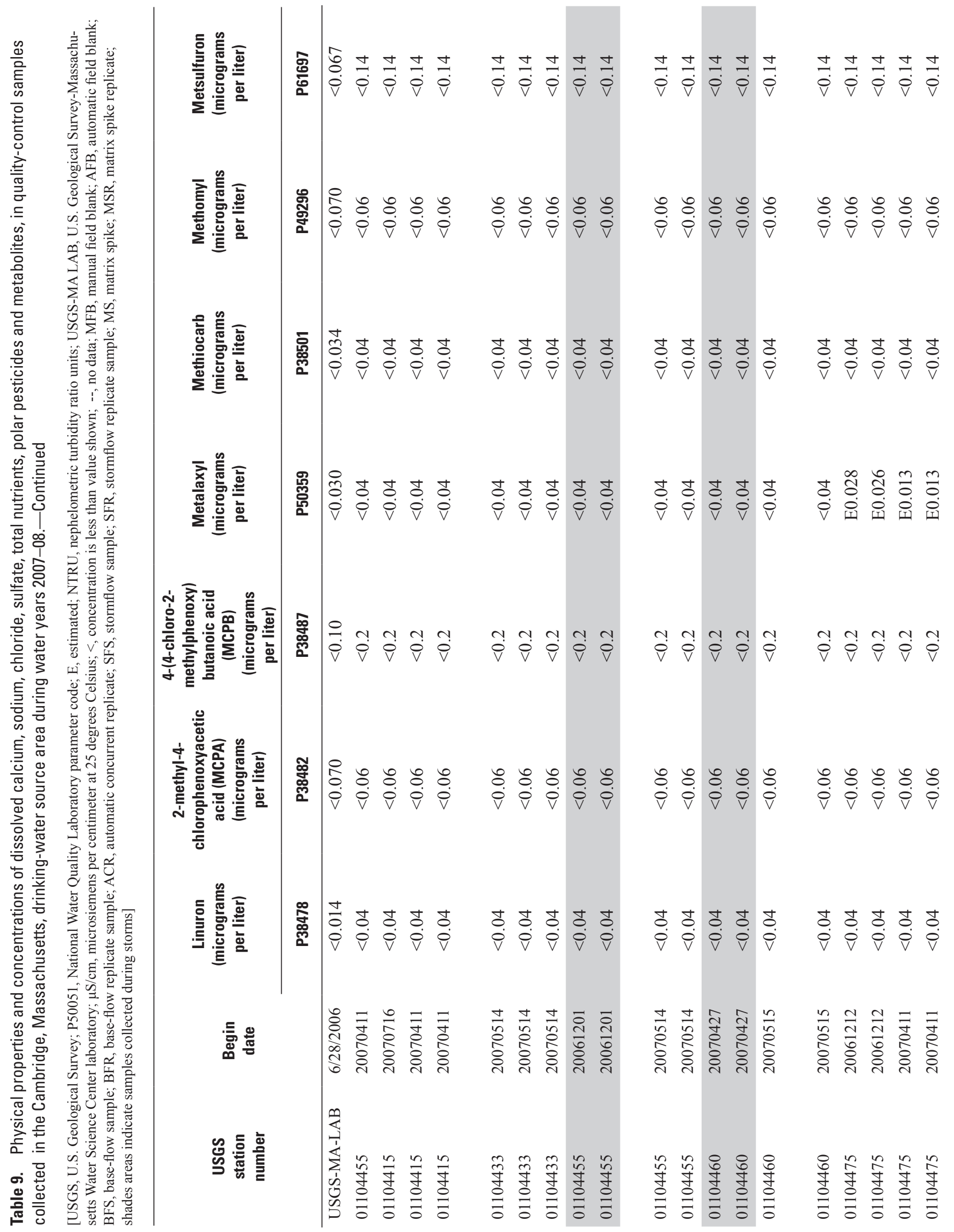




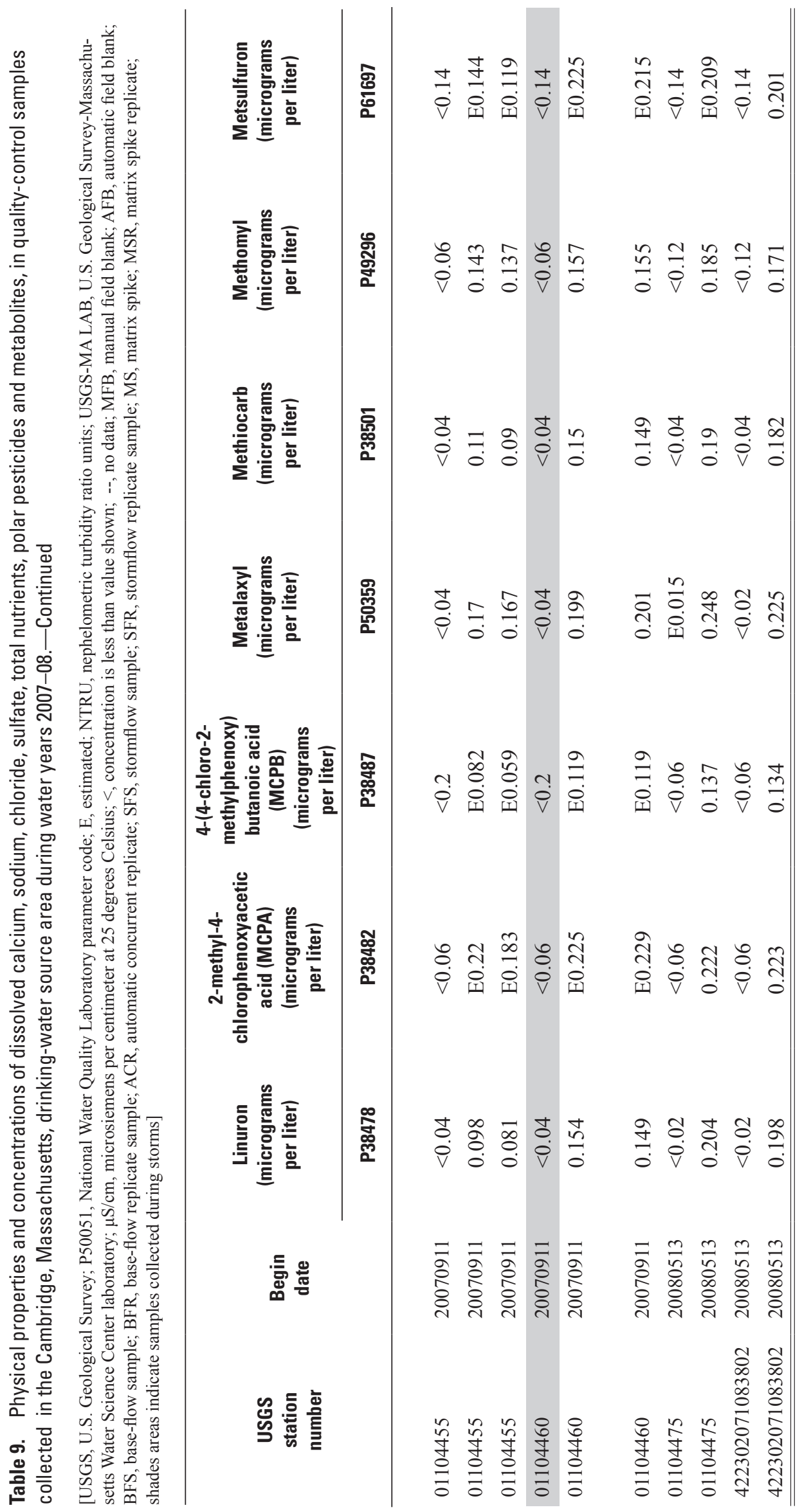




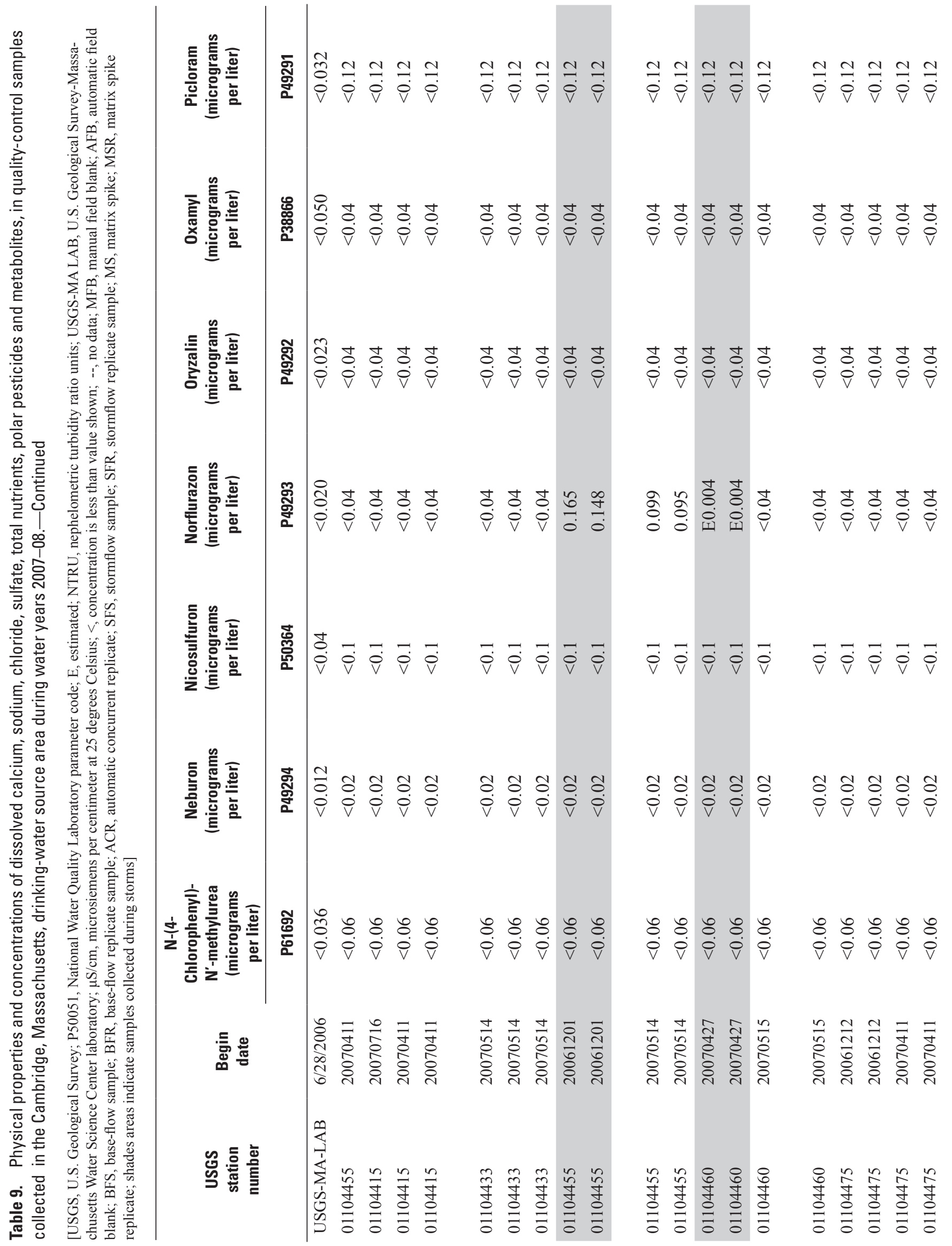




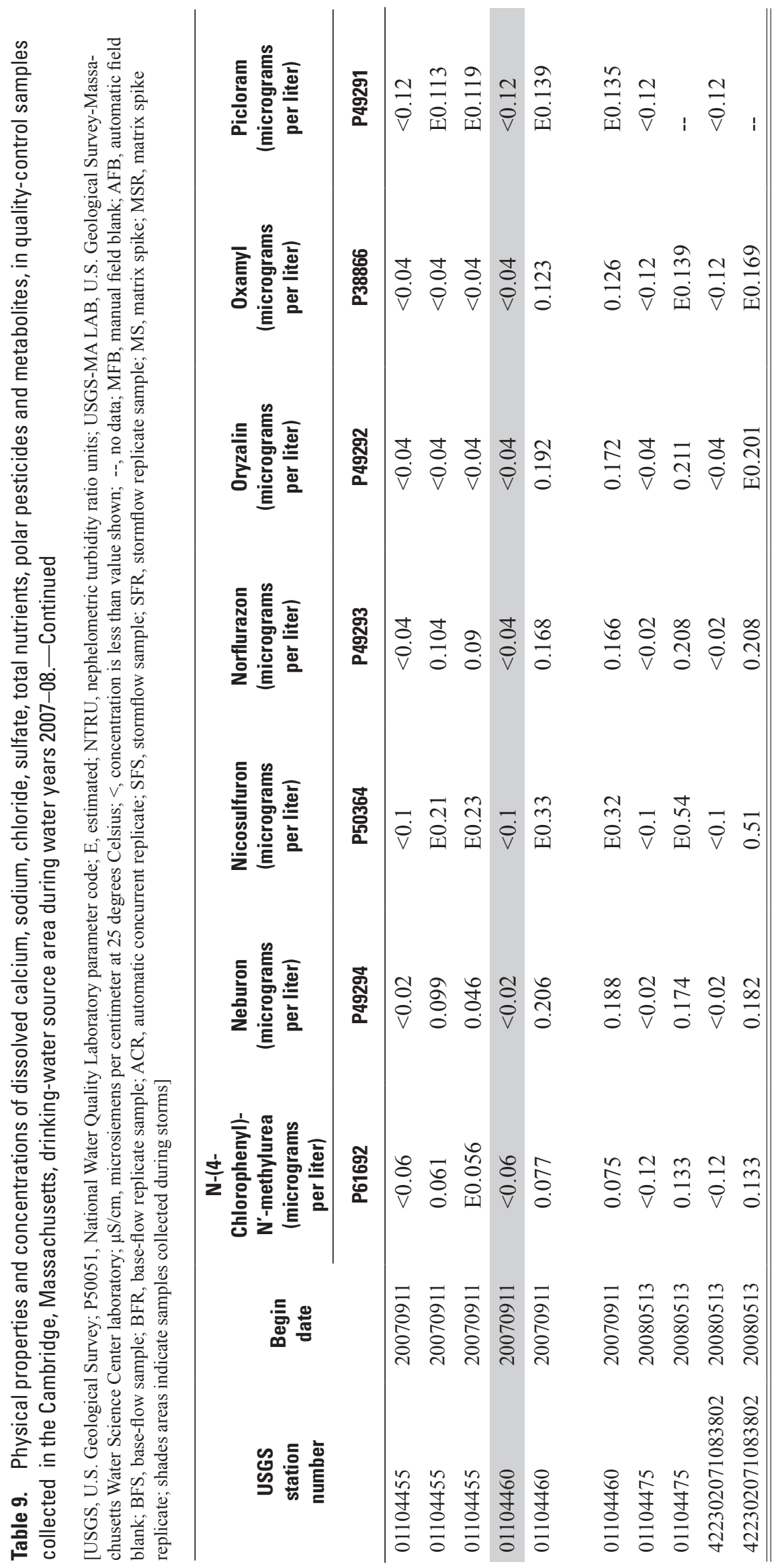




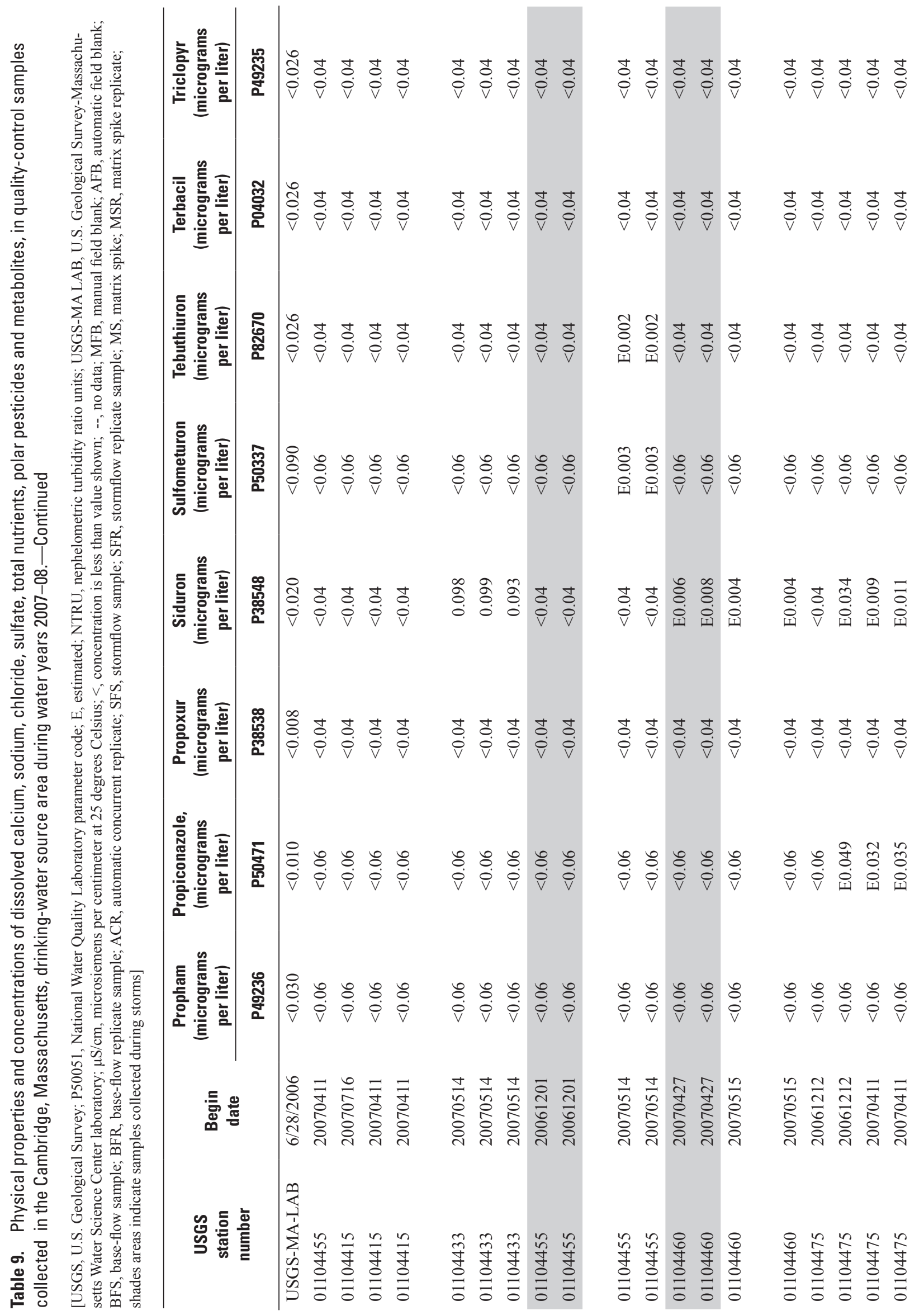




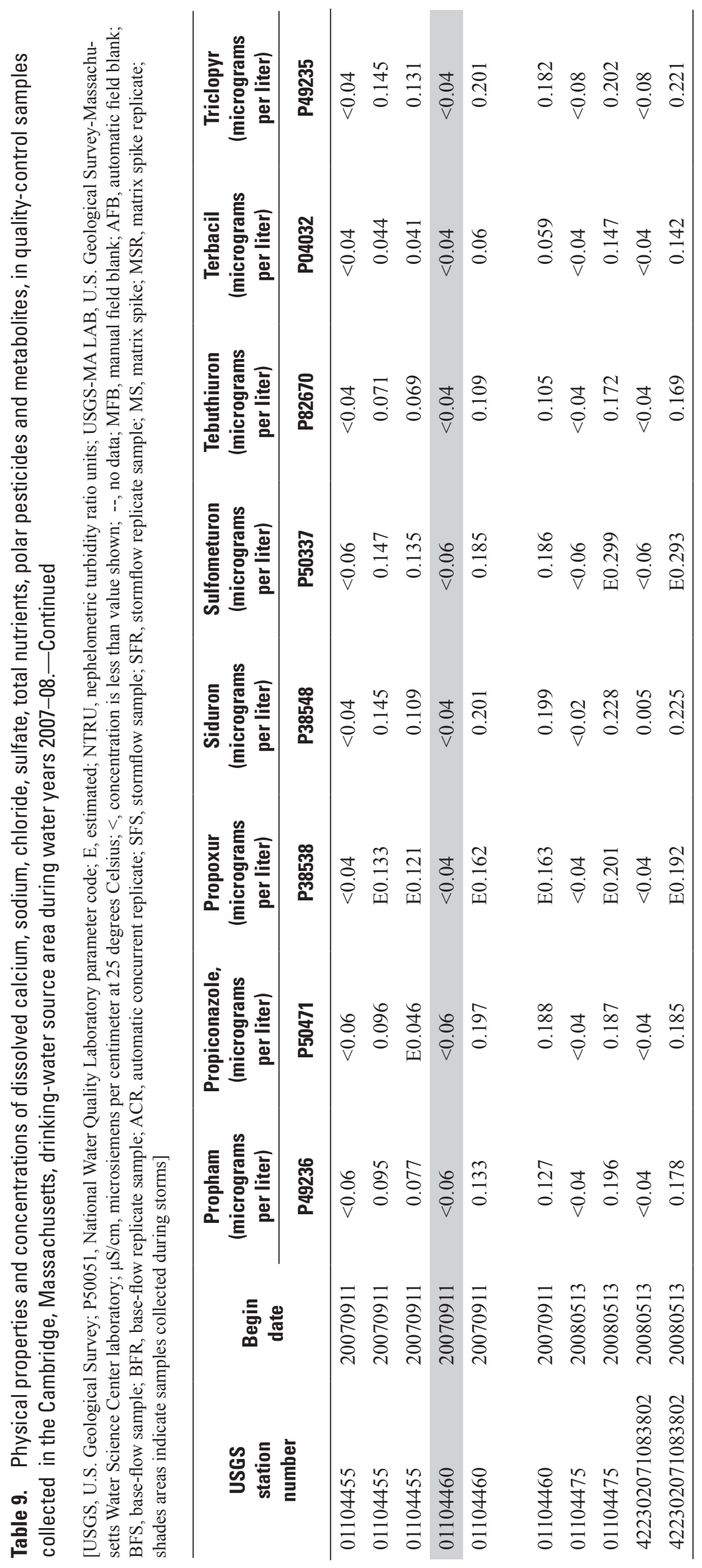


This page has been left blank intentionally. 
Prepared by the Pembroke and Raleigh-

Fort Lauderdale Publishing Service Centers.

For more information concerning this report, contact:

Director

U.S. Geological Survey

Massachusetts-Rhode Island Water Science Center 10 Bearfoot Road

Northborough, MA 01532

dc_ma@usgs.gov

or visit our Web site at:

http://ma.water.usgs.gov 


\section{总}

